\title{
Resource Flows and Technology Adoption in Tamale, Ghana: Implications for Urban and Peri-Urban Vegetable Growers
}

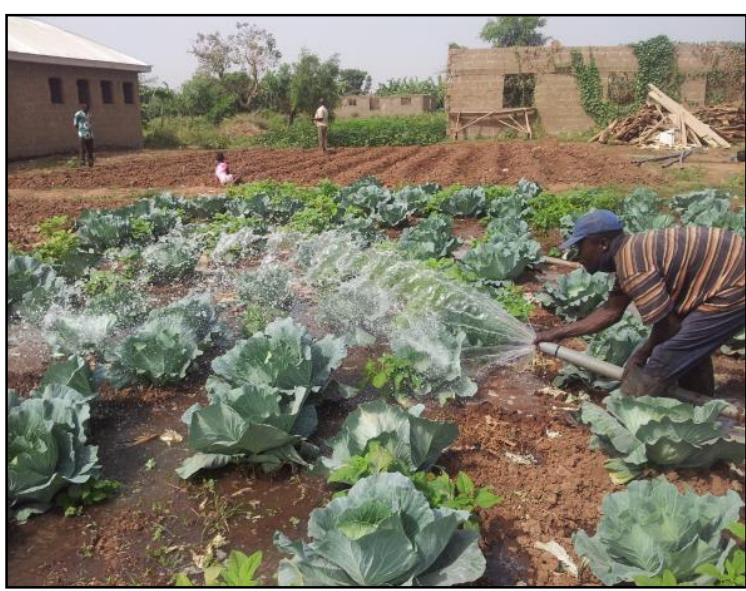

\author{
Dissertation \\ for Conferral of a Doctoral Title \\ by the Faculty of Social Sciences \\ at the Georg-August University of Göttingen
}

Submitted by

Eileen Bogweh Nchanji

Born in Bangang, Cameroon

Göttingen, 2018 
First assessor

Additional Supervisors

Other members of the Examination Committee

Date of Examination
: Prof. Dr. Nikolaus Schareika

: Prof. Dr. Axel Drescher

: Dr. Imogen Bellwood-Howard

: $17 / 06 / 2017$ 


\section{Dedication}

To my beloved mother, Ma Nchanji Margaret Mujip, who introduced me to food farming in our backyard at a time when I was just beginning to notice the world around me. It was through her that I understood the importance of farming and the joy and dignity that it gave those who practice it. Through her, I also understood the connections between life and farming. As she always said, "whatever you sow and how you sow it determines what you harvest".

And

To my father, Nchanji Maurice Chifu, who encouraged me to believe in myself. He always introduced himself as a farmer (planter) before he introduced himself as a technical adviser at the Cameroon Development Corporation. In a society where the latter profession was valued far more than the former, doing so was my father's way of changing people's perceptions about farming and of being humble. Those values which he instilled in me have allowed me to build excellent rapport with farmers wherever I went. I am proud to have you both as my parents and I love you both so much. 


\section{Abstract}

Vegetable farming in Ghana`s urban areas is mostly a sustainable livelihood strategy. Although it is considered a means of survival for the poor, vegetable farming is practiced by urban dwellers across the income spectrum. As poverty and urban population increase, so is the need to supplement income with privately cultivated foodstuff.

In Ghana's Northern Regional capital of Tamale, vegetable farming is constrained by a number of factors including land availability, land tenure security, and access to water. As a result, many vegetable farmers have resorted to cultivating lands along streams and canals, dugouts, wells, broken sewers, and reservoirs.

The scarcity of land for vegetable farming in the urban and peri-urban areas of Ghana is as the result of competition. Farming competes with other land use forms such as industry and housing, both of which attract higher economic rents. The most serious threat to farmers posed by urbanization is the changing land use pattern. Changes in land use have resulted in less availability of prime agricultural land for farming which has lowered agricultural production, food security, and standard of living. Such is the situation in the Tamale metropolitan area and its surroundings in Ghana's Northern Region.

This study analyzes the socio-political process by which resource flows are directed towards the production and selling of vegetables in Ghana's urban areas. It examines how this process is managed by farmers through different governance systems in diverse socioeconomic environments which prompt them to value the different technologies differently.

I employed a mixed-method approach for this study after a general random sampled survey, and a participatory appraisal was conducted to characterize the urban and peri-urban agricultural system. I collected quantitative spatial data by measuring all open space cultivated areas with a Global Positioning Systems (GPS). Aerial maps were obtained with an Unmanned Aerial Vehicle (UAV) and mapped with ArcGIS software. Images from Google Earth maps triangulated farmers' recollection. Qualitative data were collected using focus group discussions, participatory photography, interviews and participant observation. This study was carried out between October 2013 and February 2015.

Results reveal that the area of cultivated farmlands has decreased by $8.3 \%$ between 2008 and 2014, even as new vegetable sites emerged in the peri-urban fringes. Even though these farming areas are reducing, vegetable farming is not a temporary phenomenon. It has shown a remarkable resistance against various constraints and maintains a niche without external initiative or support as it takes advantage of market proximity, the high demand for perishable cash crops and the typical lack of refrigerated transport. Although farmers change their location over time, other open areas - usually those unsuited for construction - have been under continuous cropping for the past century. 
This study found that conflict between traditional and government institutions over land ownership and management has inadvertently led to innovative provisioning in vegetable production in the city, even though it has simultaneously threatened its contribution to food and nutritional security. Innovative strategies for continual vegetable production have emerged as a result of cordial relationships and networks that have developed between farmers and other actors. For example, farmers cultivate public green zones and floodplains which cannot legally be sold by chiefs nor used to construct government buildings. Farmers are also building alliances with Non-Governmental Organizations (NGO) that see urban agriculture as a viable activity and survival strategy for urban and peri-urban dwellers to maintain agricultural activity.

Furthermore, the lack of a legal framework for urban farming in the Tamale area has led to conflicts between traditional and state institutions with implications for land tenure management systems. The conflict is often between the various chieftaincy institutions, the Lands Commission, the Administrative Office of Stool Lands, and the Town and Country Planning Department. Claim to land and other resources is made through historical recollections, public discourses, and technology. For example, farmers use stories from past events to legitimize their claims over land or restructure development discourses while chiefs rely on public discussions and discourses which support their rights as customary landowners to lay claim to lands. Chiefs also make use of the statutory laws and the 1992 Constitution which empowers the chieftaincy institution and puts within its jurisdiction lands not claimed by the government.

To circumvent boundaries created by chiefs and others, farmers employ technologies such as fencing and pipe-borne water connections systems. Their efforts are supplemented by non-governmental organizations who furnish them with equipment such as solar-powered irrigation facilities, greenhouses, and improved seeds in order to boost their production.

Moreover, women's access to farmland has always been hampered by the reconstruction of traditions that support male dominance in land affairs. However, some recent policy developments have renegotiated the condition of access to farmlands in favor of women. For instance, the introduction of gender-sensitive agricultural practices on government irrigation sites has resulted in the allocation of plots of land directly to women as opposed to through their male relatives as it was previously done. This has revolutionised the traditional gender roles in agriculture and has empowered women through primary land ownership. Women's ownership of land on irrigation sites is a novel finding that contributes to the broader literature on gender and resource access in Ghana and Africa.

The theoretical implication of this study is that farmers' choice of, or relationship to, various local, national, and international actors is not foreordained but is instead based, to a large extent, on pragmatism. For example, by shifting alliances between non-governmental organi- 
zations and the government or supreme chiefs, they facilitate cooperation and possible negotiation for access and control over resources in their interests. Farmers also use multiple forums like meetings and courts to be able to gain legitimacy and challenge existing governance systems. Actors sometimes ignore or employ distinct strands of governance or undermine them to achieve their aims. These challenges are often used to gain legitimacy for the governance systems they are allied with. In the process of choosing one governance system over another, a new governance system comes into being. In other cases, combinations of different governance systems are forced to construct new hybrid systems tailored to an actor's interest.

To conclude, the interplay between the various actors (farmers, traditional chiefs, government and non-governmental agencies) is not always a simple case of cooperation or conflict. Instead, it is a malleable process of mutual reshaping and co-construction of the governance systems which reconfigure gender roles, improve access to scarce lands, and increase food security.

It is my strong recommendation that urban planning policy makers integrate agriculture into the larger discourse about poverty reduction and the alleviation of food insecurity. Green zones and flood-prone government lands in the urban areas which are currently been wasted should be allocated to farmers for food cultivation. This, however, must come with clearly defined mandates and guidelines that err on the side of transparency in land allocation and ownership. Innovative methods such as the farming of vegetables in sacks and other locally suitable means of maximizing production should be introduced alongside the strengthening of farmers' capacity to adopt those means. 


\section{Zusammenfassung}

Der Anbau von Gemüse in urbanen Gebieten stellt eine nachhaltige Strategie zur Nahrungsmittelsicherheit dar. Obwohl Gemüseanbau oft als Überlebensstrategie armer Bevölkerungsgruppen betrachtet wird, praktizieren inn städtische Bewohner aller Einkommensschichten. Angesichts wachsender Bevölkerungszahlen in den Städten und steigender Armut wird der Anbau von Nahrungsmitteln zu einem entscheidenden Faktor der Existenzgrundlage, auch wenn er in vielen Entwicklungsländern - so auch in Ghana - offiziell untersagt ist. Im städtischen Großraum Tamale, im Norden Ghanas, wird Gemüseanbau durch Landknappheit, unklare Besitzverhältnisse und Wassermangel beeinträchtigt. Farmer weichen deshalb auf Flächen entlang temporärer Bachläufe, Abwasserkanäle, Erdlöcher, Brunnen, kaputter Abflussrohre und Rückhaltebecken aus.

Urbanisierung und steigende Marktwerte für Land sowie unregulierte Grundstücksmärkte haben zu einem Anstieg an Landverkäufen in urbanen und peri-urbanen Gebieten geführt. Dabei konkurriert urbane Landwirtschaft mit anderen - ökonomisch gewinnträchtigeren - Formen der Landnutzung, wie beispielsweise der Industrie und des Wohnungsbaus. Für die Farmer besteht das größte Problem des rasanten urbanen Wachstums in den sich verändernden Landnutzungsmustern. Diese haben nicht nur zu einer Verringerung primärer Ackerflächen geführt, sondern auch zu geringerer landwirtschaftlicher Produktivität, einem niedrigen Lebensstandard und Nahrungsmittelunsicherheit. Die Situation im städtischen Großraum Tamale und den umliegenden Gebieten bildet diese Veränderungen besonders eindrücklich ab.

Die vorliegende Arbeit analysiert die sozio-politische Konfiguration, die Ressourcenflüsse in Aktivitäten der urbanen Landwirtschaft, verstanden als Produktion und Vermarktung landwirtschaftlicher und gartenbaulicher Produkte, kanalisiert. Sie untersucht, wie die Farmer diesen Prozess durch verschiedene Governance-Systeme in ihren jeweiligen sozio-ökonomischen Umgebungen bewältigen und es notwendig machen, verschiedene Technologien in unterschiedlichem Maße zu bewerten und einzusetzen.

Nach einer allgemeinen Stichprobenumfrage in Kombination mit einem ParticipatoryAppraisal-Ansatz zur Feststellung der spezifischen Eigenschaften des urbanen und periurbanen landwirtschaftlichen Systems, habe ich ein Mixed-Method-Design für meine Studie angewandt. Mit Hilfe des Global Positioning Systems (GPS) erfasste ich quantitative räumliche Daten aller freistehenden Anbauflächen. Mit einer unbemannten Drohne wurde eine Luftbildvermessung durchgeführt und mit der ArcGIS Software kartiert. Zusätzlich habe ich Google Earth-Aufnahmen mit Erinnerungen von Farmern trianguliert. Qualitative Daten erhob ich durch Gruppendiskussionen, mit Hilfe teilnehmender Fotografie, in Interviews und durch 
teilnehmende Beobachtung. Die Forschung fand zwischen Oktober 2013 und Februar 2015 statt. Die Ergebnisse zeigen, dass sich die landwirtschaftlich genutzte Fläche in Tamale und Umgebung zwischen 2008 und 2014 trotz gleichzeitiger Entstehung neuer Gemüsefelder an den Stadträndern um 8,3 \% verringerte. Obwohl die landwirtschaftlichen Flächen weniger werden, ist Gemüseanbau kein temporäres Phänomen. Der Gemüseanbau hat eine außergewöhnliche Resistenz gegen verschiedene Widerstände bewiesen und ohne externe Initiative oder Unterstützung eine Nische eingenommen. Er profitiert dabei von seiner Nähe zum Markt, der hohen Nachfrage nach schnell verderblichen Produkten und den fehlenden Möglichkeiten, Waren gekühlt zu transportieren. Obwohl Farmer immer wieder ihren Standort wechseln, sind andere Freiflächen - oftmals diejenigen, die als Bauland ungeeignet sind das gesamte letzte Jahrhundert hindurch landwirtschaftlich genutzt worden.

Die Studie zeigt, dass Konflikte zwischen traditionellen- und Regierungsinstitutionen um Landbesitz und -management die Nahrungsmittelsicherheit nicht nur gefährden, sondern gleichzeitig auch zu innovativen städtischen Versorgungsstrukturen führen. Im Zusammenspiel aus freundschaftlichen Beziehungen und Netzwerken zwischen Farmern und anderen Akteuren sind innovative Strategien hervorgegangen. Beispielsweise werden Überflutungsgebiete oder öffentliche Grünanlagen kultiviert, die weder von Chiefs verkauft noch von der Regierung bebaut werden können. Auch erschließen sich die Akteure den Kontakt zu Nichtregierungsorganisationen, die in der urbanen Landwirtschaft eine Überlebensstrategie und eine zukunftsfähige Alternative zur Herstellung von Nahrungsmittelsicherheit sehen und die Gemüsegärtner folglich unterstützen.

Komplexe sozio-politische Realitäten wie der Mangel an verlässlichen legalen Rahmenbedingungen für städtischen Anbau führen durch unterschiedliche Landmanagementsysteme zu Konflikten zwischen "traditionellen" und staatlichen Institutionen. Akteure in diesen Konflikten sind Chieftaincy-Institutionen, die Landkommission, das Administrative Office of Stool Lands, sowie die Stadt- und Landschaftsplanungsbehörde. In ihrem Zusammenspiel kreieren diese Institutionen Räume, in denen Ressourcenzugang und -kontrolle in Form historischer Zugänge, öffentlicher Diskurse und Technologien immer wieder neu geformt werden. Zum Beispiel instrumentalisieren Farmer historische Erzählungen oder eignen sich Entwicklungsdiskurse an, um Landzugang einzufordern. Chiefs hingegen schöpfen ihre Autorität aus öffentlichen Diskursen, die sie als gewohnheitsmäßige Landeigentümer legitimieren. Sie beziehen sich darüber hinaus auf die Verfassung aus dem Jahr 1992, die Chiefs mit Machtressourcen ausstattet, indem sie ihnen erlaubt, Landfragen direkt zu klären sowie enteignetes Land an die Besitzer zurückzugeben, sofern die Regierung es nicht mehr benötigt. Um ihre Ansprüche auf Land geltend zu machen, errichten Farmer hingegen Umzäunungen, entfernen territoriale Markierungspfosten und zapfen Wasserleitungen an. Nichtregierungsorganisationen unterstützen die Farmer, indem sie innen 
Zugang zu Technologien wie solarbetriebene Bewässerung, Treibhäuser und verbessertes Saatgut ermöglichen.

Der Zugang von Frauen zu landwirtschaftlich nutzbarem Land in einer mehrheitlich männlichen dominierten Produktionsweise wird erschwert durch eine permanente Rekonstruktion von Tradition, die eine männliche Herrschaft in Landangelegenheiten reklamiert. Dennoch verfügen Frauen über eine Vielzahl flexibler Strategien, um sich trotz Knappheit Zugang zu Land zu verschaffen und ihrer Rolle in der Versorgung des Haushalts nachzukommen. An Bewässerungsstandorten, die von Regierungsbehörden kontrolliert und verwaltet werden, wurden Bewirtschaftungspraktiken zur Unterstützung von Frauen eingeführt, die es den Frauen ermöglichen, direkten Landzugang zu erhalten, anstatt wie gewohnheitsrechtlich Zugang zu Land ausschließlich über ihre Ehemänner zu erhalten. Hierdurch ergaben sich Veränderungen in den Besitzverhältnissen der Frauen gegenüber Land. Landbesitz von Frauen in der Umgebung von Bewässerungsstandorten stellt ein bislang ungeschildertes Phänomen in der Literatur über Gender und Ressourcenzugang in Ghana und in Afrika im Allgemeinen dar.

Die theoretischen Implikationen der Studie beziehen sich auf die Erkenntnis, dass Farmer Akteure sind, die überlegte Entscheidungen zwischen unterschiedlichen innen zur Verfügung stehenden Governance-Systemen treffen, um ihre Interessen bestmöglich durchzusetzen. Indem sie beispielsweise innerhalb ihres Netzwerks aus diversen Unterstützern wie Nichtregierungsorganisationen, Chiefs und Regierungsbehören manövrieren, verhandeln sie effektiv den Zugang zu und die Kontrolle über Ressourcen. Auch nutzen Farmer diverse Foren wie zum Beispiel Versammlungen und Gerichtsverhandlungen, um ihre Ansprüche durchzusetzen und zu rechtfertigen und um bestehende GovernanceStukturen zu hinterfragen. Sie ignorieren administrative Vorgaben oder umgehen sie, um wiederum diejenigen Governance-Systeme zu stabilisieren, mit denen sie sich verbündet haben. Im Prozess des Entscheidens für ein bestimmtes Governance-System und damit gegen ein anderes, entsteht ein neues Governance-System. In einigen Fällen werden mehrere Governance-Systeme miteinander verknüpft, so dass neue, an die Interessen des jeweiligen Akteurs angepasste hybride Systeme entstehen.

Zusammenfassend lässt sich feststellen, dass Interaktionen zwischen Akteuren nicht nur Szenarien von Kooperation und Konflikt darstellen, sondern darüber hinaus auch Prozesse der gegenseitigen Gestaltung und der Ko-Konstruktion von Governance-Systemen sind. Diese spielen eine entscheidende Rolle dafür, wie Gender, Landknappheit und Nahrungsmittelsicherheit mit dem Zugang zu und der Kontrolle von Ressourcen in urbanen und peri-urbanen Gebieten interagieren. Die auf Grundlage dieser Ergebnisse formulierte Empfehlung lautet, dass Stadtplanungspolitiken das Phänomen der urbanen Landwirtschaft integrieren müssen, wenn städtische Armut verringert und Nahrungsmittelsicherheit 
gewährleistet werden soll. Überflutungsgebiete oder Grünflächen sollten Farmern legal und transparent im Hinblick auf die Zuteilungsmechanismen zur Verfügung gestellt werden. Neue Formen von städtischer Landwirtschaft wie Gemüseanbau in Säcken oder andere innovative Methoden, die der sozialen Realität der Stadtbewohner angepasst sind, sollten eingeführt und die Kapazitäten der Farmer gestärkt werden, sich diese anzueignen.

Schlagwörter: Gemüseproduktion, Technologie, Ressourcen, Beziehungen, Legitimität, Zugang, Governance 


\section{Acknowledgements}

This doctoral thesis was carried out under the UrbanFoodPlus project which is financially supported by the Federal Ministry of Education and Research (BMBF) under the GlobE (Research for Global Food Supply, grant number 031A242 C - Göttingen) initiative. I will like to thank the German Ministry for this opportunity which has not only resulted in the writing of this paper but also in the generation of valuable networks for my personal and professional developments.

The writing of this paper was also made possible thanks to the support and the encouragement that I received from so many people. To all those who helped me I say, thank you. I also will like to thank God for this opportunity, and for making my stay in Germany a successful one.

My sincere gratitude goes to professors Nikolaus Schareika, Axel Drescher, and Dr. Imogen Bellwood-Howard for their guidance throughout this process. I am equally grateful to my colleagues and friends at the Institute of Social and Cultural Anthropology for their support during this process. Special thanks go to Bukari Kaderi, Takemore Chagomoka, Djohy Georges, Samuel Mhajida, Barbara Loehde, Jannik Schritt, and Annika Witte.

I equally owe a profound gratitude to prof. Gordana Kranjac-Berisavljevic at the University for Development Studies, Dr. Gabin Korbéogo at the University of Ouagadougou, and Dr. Schlesinger Johannes at the University of Freiburg, with whom I consulted on several occasions. Their feedbacks and inputs were invaluable.

Will be remiss if I do not express how grateful I am for the support and encouragement that I received from my siblings Edmund Ndi Nchanji, Nchanji Eugene Yuniwo, and Yvonne Kiki Nchanji. Special thanks to my uncles Nchanji Guillaume, Nchanji Gilbert and my sister-inlaws Beatrice, Grace, Pascaline, and Mama. Many thanks to my lovely nieces and nephew Jayden, Jayda, and Mujip (jojolito) for giving me reasons to carry on in the most difficult of times. To my strongest support group in Germany - Arnika Peselmann and Serena Müller - I am very thankful for the support you gave me.

Last but not least, I will like to especially thank my assistants, Mr. Baako and Baba, for making my field research possible and fun. Special thanks to all the vegetable farmers and representatives of the Ghanaian government for their time and cooperation. I am especially grateful to the chiefs, the various land agencies, and the officers at the Ministry of Agriculture for their time and cooperation. 


\section{List of Abbreviations}

ADB

ADC

AFD

AFPLAN

AGRA

AGRF

ANT

ARPS

BNI

BUSAC

CIDA

CIMMYT

CLS

CORAF/WECARD

CRI

CRIR-CSI

CWSA

DC

DCE

DFID
Agricultural Development Bank

Agricultural Development Corporation

Agence Française de Développement

Regional Food Plan for Africa

Alliance for a Green Revolution in Africa

African Green Revolution Forum

Actor Network Theory

Aborigines Rights Protection Society

Bureau of National Investigations

Business Sector Advocacy Challenge Fund

Canadian International Development Agency

International Maize and Wheat Improvement Center

Customary Land Secretariat

Conseil Ouest et Centre Africain pour la Recherche et le Développement Agricoles/ West and Central African Council for Agricultural Research and Development

Crop Research Institute

Council for Scientific and Industrial Research - Crop Research Institute

Community Water and Sanitation Agency

District Assembly

District Chief Executive

Department for International Development 
ECOWAS

ETC GROUP

EPA

FAO

FBO

FGD

GGDP

GIZ

GMO

GPS

GR

GRAIN

GSRA

GTZ

GUMPP

GWC

GWCL

GWSC

IDA

IFAD

IITA

IMF

INGO
Economic Community of West African States

Action Group on Erosion, Technology and Concentration

Environmental Protection Agency

Food and Agricultural Organisation

Farmer Based Organisation

Focus Group Discussions

Ghana Grain and Development Project

Deutsche Gesellschaft für Internationale Zusammenarbeit

Genetically Modified Organisms

Global Positioning Satellite

Green Revolution

Genetic Resources Action International

Ga State Reformation Association

German Technical Cooperation or Deutsche Gesellschaft für Technische Zusammenarbeit

Ghana Urban Management Pilot Project

Ghana Water Company

Ghana Water Company Limited

Ghana Water and Sewerage Corporation

Irrigation Development Agency

International Fund for Agricultural Development

International Institute of Tropical Agriculture

International Monetary Fund

International Non-Governmental Organisation 
IPR

ISIS

KFW

LACOSREP

LAP

LC

LPA

MoFA

MOFEP

NC

NDC

NDF

NEDCO

NGO

NLSP

NPP

NRVFU

OASL

OPP

PNDC

PRS

PSH

PVS

RAFI
Intellectual Property Rights

Import-Substitution Industrialization

Kreditanstalt fur Wiederaufbau

Land Conservation and Smallholder Rehabilitation

Land Administration Program

Lands Commission

Lagos Plan for Action

Ministry of Agriculture

Ministry of Finance and Economic Planning in Ghana

Nutrition Committee

National Democratic Congress

Nordic Development Fund

Northern Electricity Department Company

Non-Governmental Organisation

National Livestock Services Project

New Patriotic Party

Northern Region Vegetable Farmer's Union

Office of the Administration of Stool Land

Obligatory Passage Point

Provincial National Defence Council

Poverty Reduction Strategy

Prebisch-Singer Hypothesis

Participatory Variety Selection

Rural Advancement Foundation International 
REGSEC

SAP

SAPs

SARI

SG

SSNIT

TAMA

TCPD

UEMOA

UAV

UDS

UNDP

Urbanet

USAID

VRA

WB

WRC

WTO
Regional Security Council

Structural Adjustment Program

Structural Adjustment Packages

Savanna Agricultural Research Institute

Sasakawa Global

Social Security and National Insurance Trust

Tamale Metropolitan Assembly

Town and Country Planning Department

Union Économique et Monétaire Ouest-Africain

Unmanned Aerial Vehicle

University for Development Studies

United Nations Development Program

Urban Agricultural Network

United States Agency for International Development

Volta River Authority

World Bank

Water Resource Commission

World Trade Union 


\section{Table of Contents}

Dedication 3

$\begin{array}{ll}\text { Abstract } & 4\end{array}$

$\begin{array}{ll}\text { Zusammenfassung } & 7\end{array}$

Acknowledgements 11

List of Abbreviations $\quad 12$

Table of Contents 16

List of Figures 19

List of Tables $\quad 21$

Chapter 1 - Introduction: Resource Politics in Urban Agriculture 22

1.1 Vegetable Gardening in the City 24

1.2 Problem statement, potential gaps in research, and rationale of study 26

1.3 Who owns land in Ghana? 31

1.3.1 Land administration after Independence: Chiefs or Government? 36

1.4 Who owns water? 38

1.5 Which seed and why? 42

1.6 Structure of thesis 45

$\begin{array}{ll}\text { Chapter } 2 \text { - Theoretical Framework } & 48\end{array}$

2.1 Effects of ambiguity and constructs $\quad 48$

2.2 The Political Ecology of government interventions 50

2.2.1 Government interventions, practices, and the notion of Governmentality $\quad 50$

2.3 Processes of access and property 56

2.3.1 Property rights and claims $\quad 57$

2.3.2 Access 58

2.3.3 Grey zones between property and access $\quad 59$

2.3.4 Legitimacy and its associated practices $\quad 60$

2.3.5 Appropriation links access to property 62

2.3.5.1 Practices of land appropriation: grounding and talking claims 63

2.3.5.2 Governmentality and appropriation at land dispute settlement meetings $\quad 64$

2.4 Conclusion $\quad 65$

$\begin{array}{ll}\text { Chapter } 3 \text { - Background of Study Area } & 67\end{array}$

$\begin{array}{ll}3.1 \text { Background of study area } & 67\end{array}$

3.1.1 Location and Origin of Tamale 68 
3.1.2 Physical Characteristics 70

3.1.2.1 Relief and drainage $\quad 70$

3.1.2.2 Climate and vegetation 72

$\begin{array}{ll}3.2 \text { Socio-economic activities } & 73\end{array}$

3.2.1 Demographic characteristics 73

3.2.2 Economic activities $\quad 74$

3.2.3 Social activities $\quad 75$

3.2.4 Land tenure 76

$\begin{array}{ll}3.3 \text { Fieldwork } & 79\end{array}$

3.3.1 Methodological considerations $\quad 79$

3.3.2 Research validity and reliability $\quad 80$

3.3.3 Researcher positionality and reflexivity 82

3.3.4 Ethical considerations $\quad 84$

3.4 Research methods and data sources $\quad 85$

3.4.1 Preparatory phase in Germany 85

3.4.2 Baseline survey $\quad 85$

3.4.3 Overview of research methods $\quad 87$

3.4.3.1 Interviews $\quad 87$

3.4.3.5 Case studies $\quad 94$

3.4.3.6 Meeting places as political arenas 95

$\begin{array}{ll}\text { 3.4.3.7 Spatial data } & 96\end{array}$

$\begin{array}{ll}3.5 \text { Sampling } & 97\end{array}$

$\begin{array}{ll}3.6 \text { Analysis } & 98\end{array}$

Chapter 4 - Dagbon and its Evolving Agricultural System 101

4.1 Origin of the Dagbon kingdom 102

4.1.1 The birth of modern Dagbon 105

4.2 Changing agricultural systems in the Northern Region 108

4.2.1 Pre-colonial era 109

4.2.2 Colonial era 117

$\begin{array}{ll}\text { 4.2.3 Post-colonial era } & 129\end{array}$

4.3 Vegetable cultivation and the advent of urbanisation in the North 134

$\begin{array}{ll}4.4 \text { Conclusion } & 137\end{array}$

3.7 Conclusion 139

Chapter 5 - Land Tenure System in Ghana 141

5.1 Traditional land tenure system 142

5.2 Transition to a dual land tenure system 143 
5.3 A dual land tenure system 148

5.4 Post-independence land tenure system 157

5.4.1 Chieftaincy and Stool land administration 161

5.4.2 Customary land tenure and Land Administration Project 168

5.5 Customary ownership under siege 174

$\begin{array}{ll}5.6 \text { Conclusion } & 175\end{array}$

$\begin{array}{ll}\text { Chapter } 6 \text { - Resource Access } & 178\end{array}$

$\begin{array}{ll}\text { 6.1 Land ownership in practice } & 179\end{array}$

6.2 How farmers gain access to farm lands 186

6.2.1 Land access through the kin and clans 186

6.2.2 Land access through private land owners 188

6.2.3 Land access through religion 190

6.2.4 Land access through non-governmental organisations 192

6.2.5 Accessing land through rental arrangements in irrigation sites 194

$\begin{array}{ll}\text { 6.3 Water rights in Ghana } & 197\end{array}$

6.3.1 Accessing community water 200

6.3.2 Access to pipe borne water 201

6.3.3 Access to stream/ well and sewage ditch 204

6.3.4 Access to water through technology 206

6.3.5 Access to water through farmer's innovation in Kabonayili 207

6.4 Seed Rights in Ghana 209

6.4.1 Formal sources of seeds 209

6.4.1.1 Access to seeds from research labs and educational facilities 210

6.4.1.2 Access through agro-dealers 211

6.4.2 Informal sources of seeds 214

6.4.2.1. Friends, relatives, and colleagues 214

6.4.2.2 Market women $\quad 215$

6.4.2.3 Access through researchers and non-governmental organisations $\quad 216$

6.5 Conclusion 216

Chapter 7 - Maintaining and Controlling Access to Resources 218

7.1 Maintaining access to land - Gumbihini extended case study 218

7.1.1 Who has control over government land used for farming 221

7.1.1.1 Land conflict between farmers, chief and a land developer in 2007

7.1.1.2 Maintaining land access through international intervention 237

7.1.1.3 Maintaining access on contested land involving the judiciary 242 
7.1.1.4 Court case between the chief of Gumbihini and Reverend/lawyer Luguterah

7.1.2 Maintaining control over communal and undeveloped private land

7.1.3 Maintain access to land in irrigation sites

7.2 Maintaining access to water

7.2.1 Maintaining access to water through technology

7.2.2 Maintaining water access in irrigation sites

7.2.3 Maintaining water access from government agency and private owners

7.3 Maintaining access to seeds

7.3.1 Maintaining access to hybrid seeds

7.3.2 Maintaining access to self-saved seeds

Chapter 8 - Conclusion: Urban Farming in a Growing African City

8.1 Urban Agriculture in a globalized city

8.1.1 The dynamics of continuity: the struggle for self-government and its link to resources

8.1.2 A transnational arena of governmentality and political struggle

8.1.3 Capturing societal change

8.1.4 Property-in-the-making

8.1.5 Governance and Subjects-in-the-making

8.2 Situating resource politics in Africa $\quad 275$

8.3 Recommendations $\quad 276$

8.3.1 Further Research $\quad 276$

8.3.2 Policy Recommendations 276

$\begin{array}{ll}\text { References } & 278\end{array}$

\section{List of Figures}

Figure 3.2: Population trend of Tamale between 1907 and 2010.

Figure 3.3: Different water sources used for vegetable gardening. 59

Figure 3.4: Effects of land commodification on cultivated land area at Buipela site. $\quad 66$

Figure 3.5: During and after focus group discussions in some vegetable sites. $\quad 79$

Figure 3.6: Pictures, showing farming practices by vegetable farmers in Tamale. 82

Figure 3.7: How data was analysed. 89

Figure 4.1: Map of Northern Ghana in 1965. 
Figure 4.2: Drawing of a Dagomba compound with the different traditional houses. 106

Figure 4.3: The partition of the Dagomba area. 110

Figure 4.4: Gold coast, 1907, showing the Northern Territories. 111

Figure 4.5: Center and periphery relationship between the Northern and Southern region in the Gold Coast.

Figure 4.6: Graphs showing different land use patterns over a period of six years in an urban and peri-urban vegetable site in Tamale.

Figure 4.7: Land use changes of Urban Tamale from 1984 to 2013

Figure 4.8: A diagrammatic illustration of governmental interventions.

Figure 5.1: Procedure for securing a land title in Accra, Greater Accra and part of Kumasi.

Figure 5.2: Historical relations between chiefs and different state authorities.

Figure 6.1: Socio-political processes of land access in Tamale.

Figure 6.2: Access to communal farmland by local indigenes.

Figure 6.3: Process of getting a lease on customary land

Figure 6.5: Sangani vegetable site with a newly constructed mosque.

Figure 6.6: Vegetable site in around uncompleted buildings in Choggu.

Figure 6.7: Vegetable site in Sahapalegu.

Figure 6.8: Female farmers at Golinga irrigation site.

Figure 6.9: My field assistant is helping a farmer to irrigate his Amaranthus spp with pipe borne water at Gumbihini new dam.

Figure 6.10: Water source at Gumbihini waterworks.

Figure 6.11: Well installed by New Energy in Zagyuri vegetable site.

Figure 6.12: Solar powered and drip irrigation facilities in Fooshegu and Datoiyili. 202

Figure 6.13: Hand-dug shallow well in Kabonayili.

203

Figure 6.14: Actors and institutions involved in the production of certified seed at the regional level in Ghana.

Figure 6.15: Improved sweet pepper variety beds in Tuunayili.

Figure 7.1: Map showing the location of the Gumbihini sites.

Figure 7.2: Allocation note on the right and receipt on the left issued for checking the validity of this plot

Figure 7.3: A pillar, a symbol of land ownership at the Gumbihini site.

Figure 7.4: An example of chieftaincy hierarchy relevant to this case study.

Figure 7.5: An example of the farmers' networks and relationships farmers use to maintain to access land.

Figure 7.6: An example of farmers' networks and relationships in maintaining access to land at the new dam site. 
Figure 7.7: Chief's network to sell land.

Figure 7.8: Reverend's network to get back the plot of land he bought or monetary rewards.

$\begin{array}{ll} & 244 \\ \text { Figure 7.9: A judgment sign post indicating this land has been sold. } & 245\end{array}$

Figure 7.10: Signpost at the Waterworks site. 246

Figure 7.11: Luguterah's network to get back his money/Land from the chief. $\quad 247$

Figure 7.12: Fooshegu reservoir in the height of the dry season 251

Figure 7.13: A greenhouse and water solar plant in Fooshegu 252

Figure 7.14: Drip irrigation site in Datoiyili with cattle herd close by 253

Figure 7.15: Bontanga Irrigation water sources. 254

Figure 7.16: An experimental plot in Gumbihini new dam site. 257

Figure 8.1: Total cultivated open space vegetable sites in Tamale over the past six years.

262

\section{List of Tables}

Table 3.1: Climatic data of Tamale. $\quad 60$

Table 3.2: Interviews conducted during fieldwork by the researcher. 77

Table 3.3: Focus group discussions conducted during fieldwork by the researcher. $\quad 80$

Table 4.1: Cereal farms destroyed by locust invasion in 1929.

Table 4.2: An urban farming survey carried out in Accra. 123

Table 5.1: Incorporation of Chiefs and Non-Chiefs into the Legislative Council 142

Table 5.2: Incorporation of Chiefs and Non-Chiefs into the Executive Council 143

Table 5.4: The Politics of LAP Aid. 161

Table 6.1: Associated water sources on open space vegetable sites in and around Tamale.

194

Table 7.1: Contested land ownership in the Gumbihini sites. 218

Table 7.2: Summary of different actors and the intermediaries they used to access and maintain control over resources. 


\section{Chapter 1 - Introduction: Resource Politics in Urban Agri- culture}

This project is focused on the politics which is endemic to resource flows and resource acquisition during dry season vegetable production in open spaces in Ghana's Northern regional capital of Tamale. Internal population growth and migration from rural areas and other regions have caused a rapid increase in the urban population. This has resulted in the encroachment of people on land previously used for agriculture. The scarcity of land, tenure insecurity, low water availability and limited access to seeds have constrained vegetable production in the region. As a result, many farmers cultivate lands along temporary streams and beside canals, dugouts, wells, broken sewers and reservoirs.

Changes in the traditional land distribution system of the indigenous people of Tamale (the Dagombas), driven by increased land insecurity, have aggravated urban pressures on peri-urban lands. Under this system, the land is held in trust for the people by chiefs and distributed to the community through families or individuals. In recent times, the high demand for land for more profitable ventures has enticed chiefs to allot and sell them to developers without consulting with the farmers to whom it was traditionally given.

As a bulwark against such moves, many farmers have begun to build alliances and negotiate with non-governmental organisations (NGOs), international agricultural organisations, researchers, educational organisations, senior chiefs, political/community elites, and the state. The goal of these alliances and negotiations is to ensure access to, and control over, resources needed for agricultural production (Callon, 1986; Ferguson and Gupta, 2002). These negotiations have taken the form of interventions which have transformed the way farmers presently engage with resources and with each other (Benda-Beckmann, 1981).

This project is focused on the politics which is endemic to resource flows and resource acquisition during dry season vegetable production in open spaces in Ghana's Northern regional capital of Tamale. Internal population growth and migration from rural areas and other regions have caused a rapid increase in the urban population. This has resulted in the encroachment of people on land previously used for agriculture. The scarcity of land, tenure insecurity, low water availability and limited access to seeds have constrained vegetable production in the region. As a result, many farmers cultivate lands along temporary streams and beside canals, dugouts, wells, broken sewers and reservoirs.

Changes in the traditional land distribution system of the indigenous people of Tamale (the Dagombas), driven by increased land insecurity, have aggravated urban pressures on peri-urban lands. Under this system, the land is held in trust for the people by chiefs and distributed to the community through families or individuals. In recent times, the high demand 
for land for more profitable ventures has enticed chiefs to allot and sell them to developers without consulting with the farmers to whom it was traditionally given.

As a bulwark against such moves, many farmers have begun to build alliances and negotiate with non-governmental organisations (NGOs), international agricultural organisations, researchers, educational organisations, senior chiefs, political/community elites, and the state. The goal of these alliances and negotiations is to ensure access to, and control over, resources needed for agricultural production (Callon, 1986; Ferguson and Gupta, 2002). These negotiations have taken the form of interventions which have transformed the way farmers presently engage with resources and with each other (Benda-Beckmann, 1981). I will investigate the effects of these interventions as they relate to existing relations, practices, and processes as stated in Li (2007a). I will also explain how the struggle for access and control is embedded in a more subtle struggle for power, authority, legitimacy, and governance by the different actors (Lund, 2006; Scott, 2009). Furthermore, I will also how attempts to intervene affect "subjects in the making" (Dean, 2010; Merlingen, 2006; Rose and Miller, 2010) managed by farmers in their diverse socio-economic environments, prompting them to value different technologies at various extents. The sub-objectives are:

1. To analyse how farmers access and channel resource and commodity flows from urban agriculture.

2. To examine how farmers maintain and use their resources in their socio-economic environment to optimize production.

3. To analyse how the existing/current resource access and management systems affect technology adoption, innovation and development.

Furthermore, I will explain how meaning is given to the socio-political and institutional dimensions of resource flows in vegetable cultivation. In the first section of this chapter, I will situate urban agriculture in Tamale amidst the rise of land markets, urbanisation, and population growth. In the second section, I will present the objectives, research problem, justification for this study, and possible gaps in research. In the third section, I will give a historical overview of traditional and contemporary laws governing access to land, water, and seed. The historical overview aims to give the reader a better understanding of how farmers' access to the resources mentioned has been shaped and reshaped over the years by different interactions and institutional changes. I will end this chapter with a structure of the thesis.

In the first section of this chapter, I will situate urban agriculture in Tamale amidst the rise of land markets, urbanization and population growth. In the second section, I will present the objectives, research problem, justification of this study and possible gaps in research. In the third section, I will give a historical overview of traditional and contemporary laws governing 
access to land, water, and seed. The historical overview aims to give the reader a better understanding of how farmers' access to the resources mentioned above due to changing sociopolitical events and historical moments has been constructed and reshaped over the years due to different interactions and institutional changes. I will end this chapter with a structure of the thesis.

\subsection{Vegetable Gardening in the City}

Urban agriculture is the production of crop and livestock goods within cities and towns (Zezza and Tasciotti, 2010). This study is framed around vegetable gardening/ farming which is a major activity in Tamale (Orsini et al., 2013). Vegetable farming in Tamale normally involves the use of small plots or patches of land near human settlements for agriculture. It is considered one of the oldest forms of food cultivation and has been practiced for more than two millennia as found in the Hammurabi code written by the Greeks and the Romans (Niñez, 1984, 1987; Zohary et al., 2012). Vegetable cultivation is not restricted to rural areas. Its practice in urban areas date back thousands of years ago (Castillo, 2003). It is an activity practised everywhere in the world and became popular in Europe and America especially after the First and Second World Wars (Pretty and Bharucha, 2014).

Urban and peri-urban agriculture have been defined differently by Mougeot, (1995), Mougeot, (2000), Mbaye and Moustier (2000), Moustier and Fall (2004), van Veenhuizen (2006) and Bon et al. (2010). However, they all make clear the link between agriculture and the city as a resource and destination of outputs. According to Pretty and Bharucha (2014) and Smith et al. (2001), an estimated 800 million people practice agriculture worldwide. Data from Lee-Smith (2010) shows that more than half the urban population of many African cities practice urban agriculture in one form or the other. Urban agriculture is used interchangeably with urban and peri-urban agriculture in this study because of the close proximity between the two zones.

Vegetable cultivation is mainly practiced for subsistence purposes as noted by LeeSmith (2010). But it is also practiced for commercial purposes to boost household resilience (Pretty, 2002; Rowe, 2009). For poor and average urban dwellers it is both a survival strategy (Galhena et al., 2013) and a means to supplement income for many households (Prain et al., 2010).

In many African countries, agriculture is mostly considered a rural activity. Urban planning in many African countries including Ghana has historically followed a Western construct which views city dwellers not as food growers but instead as wage earners. The failure of the Structural Adjustment Programs (SAP) in the 80's and 90's and the subsequent economic crises amongst other factors revived urban agriculture in developing countries especially in 
Africa (Castillo, 2003). Even though urban agriculture provides most of the fresh vegetables consumed in the city, it is still illegal in many African countries (Nugent, 2000).

Tamale is the administrative and commercial hub of Northern Ghana. It is a fast growing city with roughly $74 \%$ of its population found in the urban area (Ghana Statistical Service, 2013) and mostly engaged in informal economic activities like independent urban farming around ditches, sewers, reservoirs, dugouts and drains (Gyasi et al., 2014). Such activities allow the use of underutilized and degraded lands such as lands under electric lands, lands affected by seasonal floods and other undeveloped public and private lands (Danso et al., 2014; Drechsel et al., 2006; Niñez, 1984; Smith et al., 2001). Urban agriculture is popular in this region despite the fact that the local government Act 462 of 1993 considers it an illegal activity (Giweta, 2011).

Globally, limited food production is seen as a threat to food security as noted in Robinson et al. (2015). However, Leathers and Foster (2009) argue that the threat to food security is distribution related. The projected increase of 860 million urban dwellers in African cities between 2010 - 2050 (Ncube, 2012; United Nations Habitat, 2008, United Nations Habitat, 2015; World Bank, 2014, World Bank, 2014) is a cause for concern. However, the projected increase could result in an increase in food production, availability, and distribution in the coming years according to Godfray et al. (2010) and Lele et al. (2010). But for that to happen, intensive agricultural methods such as urban agriculture must play a major role and could if threats to agricultural production posed by urbanisation are addressed.

Urbanisation poses a threat to agriculture by exerting pressure on water and land resources (Gyasi et al., 2014; Naab et. 2013). Competition for land between developers and farmers means growing more food on very limited plots of land. The plots of land used for urban agriculture in Africa usually range between 0.1 - 0.6 acres per farmer according to Andreas de Neergaard et al. (2002). The growing impacts of climate variability and change have been argued by Dubbeling (2013) to be an additional source of danger to this form of agriculture; even though it can also play a role in mitigating and adapting to these changes (Lwasa et al., 2014; Lwasa and Dubbeling, 2015).

In many African countries, agriculture has and is still considered an activity meant for the rural areas. Urban planning in many African countries, including Ghana, followed a historically constructed Western model, with an assumption that city dwellers will earn wages to buy food and not grow food in the city. The failure of the Structural Adjustment Programs (SAP) in the 80's and 90's and subsequent economic crisis amongst other factors revived urban agriculture in developing countries especially in Africa (Castillo, 2003). Even though urban agriculture provides most of the fresh vegetables consumed in the city, it is still illegal in many African countries (Nugent, 2000). 
Tamale is the administrative and commercial hub of Northern Ghana. It is fast growing city with $74 \%$ of its population found in the urban area (Ghana Statistical Service, 2013) and mainly involved in informal economic activities. According to the local government Act 462, 1993, urban agriculture is an illegal activity, even though practiced in the city (Giweta, 2011). It is an activity which is mostly practiced around ditches, sewers, reservoirs, dugouts and drains (Gyasi et al., 2014). Urban agriculture allows the use of underutilised and degraded lands, such as lands under electric pools, lands affected by floods seasonally which are usually undeveloped public and private lands (Danso et al., 2014; Drechsel et al., 2006; Niñez, 1984; Smith et al., 2001).

The proximity of the gardens to markets and the relatively suitable transport systems provide producers with a market niche (Gockowski et al., 2003). However, despite these advantages, urban agriculture, mainly dry season vegetable gardening, continues to face some severe challenges in northern Ghana. One of those challenges is the limited water resources which push some vegetable growers to resort to using wastewater for irrigation. This produces serious health risks for both the farmers (water-borne disease for instance) and the consumers of those vegetables. Other challenges include land scarcity. Land for real estate fetches more money than land for agricultural purposes. As a result, local land authorities such as the chiefs prioritise the needs of real estate developers over farmers.

As mentioned above, the realities facing farmers in cultivating vegetables in the city are complex, especially in accessing resources like water, land, seeds and others integral to this agricultural practice. This study analyzes the socio-political configuration through which resources - in particular land, water, and seed - are channeled to vegetable farming. It will also focus on how farmers draw on different bundles of powers - from individual actors, a group of actors, institutions, and organizations to be able to gain access, maintain and control resources implicated in this agricultural practice.

The following section identifies the research problem/ question, identifies possible gaps in the research, and provides a justification for the study.

In the next section, I will pose the problem, possible gaps in research and a justification for this study.

\subsection{Problem statement, potential gaps in research, and rationale of study}

Urban farming is critical to the survival of many urban dwellers in the developing world (Nugent, 2000). As Drechsel and Dongus (2010) note, vegetable gardening is a dynamic livelihood strategy which supplements the incomes of many urban dwellers. Yet, the practice remains illegal in many parts of the developing world. 
The illegality of urban agriculture in many African states can be traced back to the colonial time period. Colonial agricultural policies in what was previously known as the Gold Coast restricted vegetable gardening to the forts and castles of European settlers. The gardens served a number of purposes including the provision of food and the beautification of the urban surroundings La Anyane (1963).

City residents along the West African coast were encouraged to grow more vegetables to feed the allied forces stationed in the Gold Coast (presently the Republic of Ghana) during the Second World War. The subsequent withdrawal of allied troops from the Gold Coast after the defeat of Nazi Germany led to a decline in urban vegetable farming. Later on, officials in various town and city councils were instructed to destroy crops in the cities for health and sanitation reasons. Although this set urban farming far back, it did not fully wipe it out (Asomani-Boateng, 2002; Obusu-Mensah, 2002).

The policy of restricting farming to rural areas has continued to the present - shaped by different socio-political institutions through formal and informal laws - resulting in new policies that nonetheless have not made urban farming wholly legal. After independence, the agricultural policy adopted was not different from that practised during colonial times. It excluded farming to the rural areas for ideological and pragmatic reasons (Janowicz, 2008). For one, the idea of the capital city of a newly independent country with a rising economy covered in green as opposed to bricks and rails was particularly unattractive to urban planners. Farming was never seen as a quick means to closing the development gap between the global North and the global South, a belief that is captured by the saying "Africans must run while the others walked" (Heidhues and Obare, 2011).

The famous Prebish-Singer Hypothesis (PSH) influenced the thinking of many African leaders of the early post-colonial time period. According to this hypothesis, the price of primary goods will decline in proportion to manufactured goods. The implication is that countries dependent on the export of primary goods may lose out from a worsening of the terms of trade. It was this caution that led many developing countries to reduce their economic dependency on primary production and instead adopt policies more favorable to industry (Acemoglu et al., 2001).

Following independence in 1957, a socialist approach to development was adopted in Ghana. The overextension of the Ghanaian government in economic affairs was based on the belief that its private sector was ill prepared for the heavy task of turning the country into an industrial powerhouse. Guided by this approach and with donor support, the government invested in large state-run primary industries and "enacted comprehensive regulations to control prices, restrict trade, and allocate credit and foreign exchange" (according to Heidhues and 
Obare (2011: 56) as cited in (Owusu, 2003). The industrialization policy was meant to eliminate the dualism that characterised developing countries between a traditional underdeveloped rural and agricultural sector and a modern, westernized urban sector (Hirschman, 1958).

After independence, many African leaders pursued policies of industrialisation of the urban centers and the restriction of agriculture to the countryside. Cities were to spearhead economic growth and human development and prosperity was to be achieved through wage labor (Castillo, 2003). With this approach came a bias which mostly favored the urban centers. Development policies mostly favored urban populations over their rural counterparts (Radetzki and Lipton, 1978).

Initially, the industrialization policies led to significant investments in infrastructures like roads, ports, telecommunications, and power generation with health and education sectors improving significantly. Annual economic growth in Sub-Saharan Africa averaged $3.4 \%$ between 1961 and 1980 while "agriculture grew by about 3\% per year over the same period". However, in the early 1970s the growth engine of many African countries began to slow down, and by the mid-1970s, their economic performance lagged behind that of other developing countries. This was reflected in waning exports, mounting debts, deteriorating socio-economic conditions, and an increasing erosion in institutional capacity (Heidhues et al., 2004).

The Lagos Plan of Action (LPA) and the Regional Food Plan for Africa (AFPLAN) were introduced to reverse the situation. Both policies have roots in the Bandung Conference of 1955, which aimed at solving the problem of underdevelopment through Import-Substitution Industrialisation (ISI) and the establishment of a bourgeois state in the third world (Heidhues and Obare, 2011). Countries which pursued the LPA and AFPLAN strategies encountered difficulties in implementing their plans due to weak government institutions and the reluctant support by the World Bank (WB) and the International Monetary Fund (IMF). These western donors did not favor any adjustment in international economic order outside free market system. In the 1980's a second set of policies was initiated and found expression in the Berg Report (World Bank, 1981), with constituted steps towards a Structural Adjustment Program (SAP) in Africa.

The SAP and its associated stabilisation policies have been one of the most critical regulatory frameworks that have impacted agricultural programs, strategies, and overall economic development in Africa (Heidhues and Obare, 2011). The IMF set the space for stabilisation policies on macroeconomics while the WB provided structural adjustment policies subject to lending. These two activities came as a package (Lipton and Ahmed, 1997). Kherallah et al. (2000) argue that technological innovation and its associated practices that are good for productivity and sustainable farming systems were neglected in favour of pricing which did not do much for the economy. Stein (1994) notes that one of the failures of the SAP was what I refer to as the "a-institutional" roots of the IMF and WB whom he considered ill-equipped to 
promote market and institutional development in Africa. It was concocted with little attention paid to how African markets are shaped by the habits and culture of the African people. Instead of economic growth and poverty reduction, the rural populations were pauperized by policies that did not support their dominant means of livelihood (Heidhues et al., 2004; World Bank, 1981).

The SAP and its associated stabilisation policies have been one of the most critical regulatory frameworks that have impacted agricultural programs, strategies, and overall economic development in Africa (Heidhues and Obare, 2011). The IMF set the space for stabilisation policies on macroeconomics while the WB provided structural adjustment policies subject to lending. These two activities came as a package (Lipton and Ahmed, 1997). Kherallah et al. (2000) argue that technological innovation and its associated practices that are good for productivity and sustainable farming systems were neglected in favour of pricing which did not do much for the economy. Stein (1994) notes that one of the failures of the SAP was what I refer to as the "a-institutional" roots of the IMF and WB whom he considered ill-equipped to promote market and institutional development in Africa. It was concocted with little attention paid to how African markets are shaped by the habits and culture of the African people. Instead of economic growth and poverty reduction, the rural populations were pauperised by policies that did not support their dominant means of livelihood (Heidhues et al., 2004; World Bank, 1981). Overall, structural adjustment was "a form of 'non-structural, partial adjustment' that was never destined to produce the expected benefit of a sustainable rural livelihood generation" (Lipton and Ahmed, 1997: 27). The counter reason given by the World Bank and IMF for the reported failure of the SAP failure in Africa was that many African countries who underwent one or two structural adjustment programs did not fully implement the whole package (Kherallah et al., 2000).

An example of a failed agricultural package resulting from the structural adjustment program in Ghana was the Sasakawa Global (SG) 2000 project which was funded by the Nippon Foundation and led by Norman Borlaug. The aim of this project was to find an alternative to food aid and make Ghana food sufficient. A large field demonstration program was set up in collaboration with the Ministry of Agriculture, the Ghana Crop Research Institute (CRI), the International Maize and Wheat Improvement Center (CIMMYT), and the International Institute of Tropical Agriculture (IITA) to grow improved maize and sorghum. Inputs such as improved seeds, fertilizers, and pesticides for post-harvest storage were loaned to farmers, with extension officers mandated to collect payments after a given period. However, as soon as the SG project was scaled-up, $45 \%$ of the farmers were unable to pay their loans. Later on, farmers were organized in associations with the hope that pressures from their peers would cause those among them who had been unable to pay their loans to do so. The strategy, however, did not produce the intended result. The inability or in some cases the unwillingness 
of many of the farmers to pay back what was loaned to them was one reasons for the failure of the SG project. An evaluation of the project concluded that the focus of the project was too narrow and that it was unable to adjust to changing markets and SAP policies at the time, and also it was insensitive to smallholder farmers' resource endowment and risk capacity (Amanor, 2010).

As already indicated, the introduction of structural adjustment packages (SAPs) and other 'reform' policies further exacerbated urban and rural socio-economic challenges as essential social services and infrastructures declined (Stren, 1992). Gardens began to crop up throughout cities in Africa and Latin America (Castillo, 2003). According to Mougeot (1994), the urban poor in the late 80 's spent about 60 to $90 \%$ of their income on food and thus the economic rationale to cultivate food. The prominence of gardens in cities awakened the interest of researchers and governments. Studies have so far concentrated on the socio-economic importance of urban agriculture and how it links to the rural agricultural system, sustainability, and food security (Lee-Smith, 2010). Hardly enough light has been shed on how relations between actors over time and across space affect resource access and property in Africa. In this study, I will look at the different processes farmers go through in order to gain access and control over agricultural control over resources. I will also explain how and with whom they build networks or alliances in order to be able to keep access routes to these resources open.

Berry (1992) observed that a lot had been written about the abundance of rural lands in Africa that are immune from both competition and political conflict. But recent studies suggest that this view is oversimplified. Land rights are increasingly being exchanged, negotiated, constructed, and transformed in urban and peri-urban areas as noted by Yaro (2010). As the urban sprawl moves outward, rural areas are being enveloped in the land use changes taking place (Yaro, 2012). Presently, the struggle to gain access to agricultural land lies more in urban and peri-urban areas where urbanisation and population pressure has created a lucrative land market in which traditional authorities have become entangled (Naab et al., 2013). As will be seen later in this thesis, the dynamics of land is very important and so much of the data will be about it. While land is not the only resource, at this developmental juncture, it is the most important resource by virtue of its scarcity.

The following section outlines how resource access has been shaped and reshaped by individual, group actors and institutions over the years to serve different agendas. It also explains how historical moments, political circumstances, and geographical discourses have been used by these different actors to garner legitimacy and recognition of their claims or rights to land. At the end, it summarises the section and relates it to the general idea of this thesis. 


\subsection{Who owns land in Ghana?}

"The openness and contingency of land issues in Africa make absolutely central the questions of how and to whose benefit settlement are reached who has the capacity to endorse or enforce them, and how and by whom they are challenged" (Lund, 2008a: 2).

To understand how land is accessed for vegetable cultivation, it is of essence to know who owns the land, the different land rights or interests in the land, and how land rights are legitimised. In Ghana, there exists a dual land tenure system that broadly consists of two institutions; the customary and statutory land institutions. Roughly $80 \%$ of land in Ghana belongs to the customary land agencies while $20 \%$ is owned by the state through the power of eminent domain (Ubink and Quan, 2008). The customary land system in Ghana can best be understood by examining its embeddedness in the religious, political, social and economic life of the people. It transcends the material realm into a spiritual realm of the ancestors. The ancestors oversee the welfare of the people who must in return acknowledge and pay homage to them. As Agbosu (2000) points out, it is for this reason that authority over land is not considered the sole exercise of the living. In other words, the dead and the unborn also have metaphysical claims to land. This highlights the importance of social relations in the context of land rights and ownership. The word land literally means "earth," and it is under the control of the earth goddess who communes with the earth priest. It is mostly through annual rituals and sacrifices that the productivity and fertility of the soil can be assured.

The acquisition of land through war and conquest has a number of implications. One, it is emblematic of the strength of a people and kingdom and two, it is a means of gaining prestige. It is one of the reasons why land is considered the property of the whole instead of the individual, and it is central to the social and political cohesion of the polity (Ministry of Land and Forestry, 2003a). Land ownership is a form of social prestige not only enjoyed by the community but also enjoyed by families and clans who control these lands (Mends, 2006, p. 12). Since lands are recognised by the members of the society and constitute part of their culture, they are not necessarily recorded. As Mends indicates, "transactions involving transfer of rights in the customary lands are not recorded, the use of the land is secured within the community through recognition by all the members." Most importantly, land is a source of livelihood and since most of the people are mainly farmers, it is a source of hope and survival. Even with the introduction of agencies to assist with the administration of land through the provision of titles, people's conceptions of land rights are still rooted in socio-cultural land practices. 
Four main customary and common law rights are recognised by the Land Title Registration Law of 1986 in Ghana. These rights and interests include allodial, freehold, leasehold, and other lesser rights or interests. Allodial right is the highest land right in the land (Boamah, 2013). Under this right, land interest is vested in the skin/stool - that is, the community represented by the chief. In some areas, land rights are also held by families and individuals as explained in Kasanga and Kotey (2001) and as we shall see in chapters 6 and 7. Although, generally speaking, land is a collective property, titleholders who represent the individual and family can "execute judicial, governance and land management functions" (Kasanga and Kotey, 2001: 13). While land under this system is there to serve the collective interests, the are many examples of appropriation of land for personal benefit by allodial holder in the urban and peri-urban Tamale (Naab et al., 2013; Yaro, 2010). All other lesser land interests can only be derived from the allodial land interest (Ministry of Land and Forestry, 2003a). Interests in or rights to land can be purchased or given as a gift to another with the consent of the elders or members of the families involved. However, land obtained through such means can be lost at the discretion of allodial holders.

According to Boamah, (2013), Sarpong (2006), Ubink and Quan (2008), and the United States Agency for International Development (2011), there exist two types of freehold on land; the customary freehold interest and the common law freehold interest. To have a customary freehold is similar to having a usufruct (use) rights. It is an interest in land held by members or indigenes of a community that hold allodial interests in the land. In this community, the members are entitled to use rights according to the customary laws of their community. In most cases, any member owning allodial interest can obtain a customary freehold title by exercising his rights through the development of a vacant land i.e. not belonging to another. $\mathrm{He}$ is allowed to occupy and derive economic gain through cultivation, building, or other means. This land right is transferable and inheritable, but it may or may not give its owner access to minerals on the ground depending on the community. If there is no successor to take over the land, then the use rights will no longer be valid and the land is taken by the community. It is worth noting that a freehold customary right owner is under the allodial proprietor. There are many controversies in different communities about what usufruct title entails and as a result, various forms do exist in different communities.

The introduction of the common law freehold interest by the British during the colonial period was intended to secure lands for European entrepreneurs in the Gold Coast. This was acquired through allodial right holders. Under that law, the parties involved decided on the rule which governed future disputes - customary or common law. The 1969 constitution of Ghana abolished freeholdership for Ghanaians and the 1979 constitution extended it to non-Ghanaians. Furthermore, Article 267 (5) of the 1992 constitution states that "subject to the provisions of this constitution, no interest in, or right over, any stool land in Ghana shall be created which 
vests in any person or body of persons a freehold interest how so ever described." This article has engendered much controversy, with different interpretations making its implementation almost impossible. One interpretation of the Article is that freehold titles no longer existed by the time the 1992 constitution came into being. However, results from field interviews reveal a general perception that those who had such claims over a piece of land are allowed to lease it for up to 99 years (for Ghanaians) or 50 years (for foreigners).

Leasehold is the right given to an individual to occupy land for an agreed period. After the agreed period, the right is either renewed or taken back by its owner. This land title is subject to the common law but not customary law. In Ghana, land leased for commercial use is usually granted 50 years and land for residential purposes 99 years. The holder of an allodial or freehold interest may grant a lease over land which has not already been given to another. Leaseholders can also grant sub leases (Sarpong, 2006; Ubink and Quan, 2008). The various rights and interests in land are further examined in chapter 6.

Lesser interests on land usually take place in farming communities, where allodial and customary land title holders lease out lands to farmers. In Southern Ghana, the "abuna" and "abusa" system prevails, where a certain portion of crop cultivated is distributed among the owners of the land and the tenants. In the abuna system, the crops are split in half while in the abusa system the tenant is given one-third of the farm produce. In the Northern region, land is usually lent to farmer who are expected to compensate the landowner in crops. There is no standard scale relating to the volume of crops or vegetables a farmer has to give to the landowner (Ministry of Land and Forestry, 2003a). In chapter 6 and 7, I shall discuss a new trend of renting lands on government irrigation sites which are similar to the abuna and abusa practices in the Southern part of Ghana.

In the Northern Region of Ghana, $80 \%$ of land is under the customary system while the remaining $20 \%$ is under the legal system or the state (Yaro, 2010). According to Larbi (2008) and the Ministry of Land and Forestry (2003a) the state manages lands classified as vested and public lands. Vested lands are customary land holdings held by customary land right holders but legally administered by the state. The customary landowners in this case still own the land and benefit from the proceeds of these lands even though its management is in the hands of the state. The 1962 Administration of Lands Act (Act 123) is the legislation that governs this unique land arrangement.

By contrast, public lands are acquired compulsorily by the state for specific purposes such as the construction of hospitals, markets, transport infrastructure, water facilities, and public ministerial services. This compulsory acquisition of land is made possible by the use of the constitutional power of eminent domain. Under eminent domain, land is vested in the President of the Republic on behalf of and in trust for the people, and all previous owners of these lands are entitled by law to fair and adequate compensation. Pieces of legislation governing 
the compulsory acquisition of lands by the state are many ${ }^{1}$, with different regulations made under these statutes. The Land Commission is the state land agency that administers state land on behalf of the president according to Article 258 (1a) of the 1992 constitution.

Other existing interests in and rights to land include common property rights, alienation rights, licenses, and other derived rights (Larbi, 2008). Common property rights are usually enjoyed by all members of the community. These include rights to community water reserves, community forests, and common grazing lands. Alienation holdings are rights acquired through the buying of land for agricultural purposes by a non-member of the community while a license may be given to someone who intends to use the land for construction or agricultural purposes. In the latter, however, the land is not alienated and license has a time limit.

The struggle for access and control over land predates the present time. Land has been exchanged, negotiated, and fought over by different kin groups and clans in many ethnic wars and expansion of various dynasties (Berry, 1992). In pre-colonial time, rights over land in what is now known as Ghana were determined by customary laws and local community customs. Those customary land laws varied from one region to another and even from one community to another (Agbosu et al., 2007). The arrival of the colonists led to the re-invention of the traditional land tenure system in Ghana (Berry, 1992; Fuseini and Kemp, 2015; Yaro, 2012; Nchanji and Bellwood, 2016a). Since the British knew, at the onset, very little about the place which they then called home, they could not anticipate the indigenes' reaction to their agenda (Obeng-Odoom, 2014). After the colonisation of the Gold Coast, scarcity of money and lack of manpower amongst other issues prompted the introduction of an indirect rule system by the British (Berry, 1992). The idea behind the system was to appease traditional rulers and gain the cooperation of their subjects by involving them in the governing process. To this end, chiefs - mostly loyal to the colonial government- were appointed as administrative heads (ibid). With the help of these chiefs and indigenous entrepreneurs sympathetic to the British colonial government, the latter imposed its own version of the existing traditional laws (ibid).

The reinvention of traditional laws and values was attempted because traditional rulers were more or less perceived to have a better understanding of the customs of the people (Firmin-Sellers, 1996; Ward, 1958). The colonists trusted the judgements of the chiefs with regards to land rights and that trust, in effect, emboldened powerful traditional leaders such as the Asantehenes to expand the Ashanti dynasty through various land consolidations in the 18th century (McCaskie, 1980; McCaskie, 1984; Tordoff, 1965; Wilks, 1975). Berry (1992) argues that the colonial regime's decision to function via traditional structures of authority inevitably pushed them into building their rule on a foundation of conflicting customary laws that

\footnotetext{
${ }^{1}$ Article 20 of the 1992 Constitution, Administration of Lands Act 1962 (Act 123), the State Lands Act 1962 (Act 125), the Land Statutory Wayleaves Act 1963 (Act 186), State Property and Contract Acts 1960 (CA 6) and the Public Conveyancing Act 1965 (Act 306).
} 
were constantly prone to changes. Customary or traditional laws are not static but ever changing due to negotiations and reconstruction amongst community members who have created networks to further their interests, taking advantage of different historical events and sociopolitical changes. For instance, when cocoa and palm oil exportation became a profitable business, many landowners who had previously sold cocoa and palm nuts farmlands successfully reclaimed their allodial rights to those lands with the help of the colonial government and the chiefs.

These conflicts had negative impacts on British entrepreneurs which led to a proposal of a Crown Land Bill in 1894 and subsequently a Land Bill in 1897. These bills proposed the confiscation of vacant lands and their administration by the Crown (Obeng-Odoom, 2014). This gave the British an opportunity to form a new system of land ownership that was more favourable to their economic activities than the customary land tenure system (Howard, 1978). Another beneficiary of the proposals was the indigenous bourgeoisie class which, as we shall see in chapter 5 , included the educated elites who, together with the chiefs, created the Aborigines Rights Protection Society (ARPS) which succeeded in repealing the Crown Land bills of 1894 and 1897. They explained that occupied lands were owned by chiefs or extended families and unoccupied were managed by the earth priest for members of the community who are alive, dead or yet unborn. Furthermore, land referred to as wasteland (land left to fallow over some period of time for subsequent cultivation) was owed by families (Howard, 1978). The abolishment of the transatlantic slave trade and the industrial revolution also had significant impacts on land tenure system in the Gold Coast.

The abolishment of the slave trade for instance, had a negative impact on traders profits while the industrial revolution increased the demand for raw materials in Africa. These developments meant a greater demand for land for agricultural activities and an increasing monetisation of the rural economy, hence the scramble for land discussed in Agbosu (1990). This created a need for laws on land alienation (Howard, 1978). As already indicated in the text, during pre-colonial rule customary laws were interpreted differently depending on the regions and even communities and many traditional authorities used this advantage to recodify customary laws to suit their interest.

The struggle to maintain access and control over land by chiefs and colonial administrators led to the reshaping and re-interpretation of land laws (Firmin-Sellers, 1996; ObengOdoom, 2014; Ward, 1958). Backed by the colonial government, many chiefs abandoned their traditional responsibilities to the land - and to their subjects for that matter - by engaging in land transactions that largely benefited them and European entrepreneurs. The latter acquired lands mostly for mining and cash crop cultivation for exports (Amanor, 2005; Howard, 1978). This transactional attitude of the chiefs was criticised by many including Kwame Nkrumah who, in 1973, stated that the chiefs were free to leave the Gold Coast with the Europeans if 
they did not desire freedom. The land tenure system of the British Gold Coast continues to be practiced in Ghana with only minor modifications Hughes (2003). For instance, although the colonial administrators have now been replaced by Ghanaian elites, chiefs still maintain control over customary lands.

Hughes observation is in line with an earlier observation by Firmin-Sellers (1996) who argues that the sanctioning of traditional chiefs` authority over the land by the 1992 constitution is a continuation of the land tenure system under British rule. Generally speaking, all land matters in Ghana are adjudicated under the chieftaincy institution (The Republic of Ghana, 1992). The land tenure systems in the Northern territories (presently Northern Ghana) and the Gold Coast (currently Southern Ghana) were different, and this is reflected in the dissimilar land tenure systems practiced in both regions today. Unlike in Southern Ghana where a laissez-faire land administrative system was practiced, land in the Northern region was nationalized by four main legislations ${ }^{2}$.

Even though lands in the North was nationalized, the reality of this act was limited on the ground, as no major land acquisition was carried out or communities displaced by the colonists (Kasanga, 2002). However, because of the lack of knowledge about the law, due in no small part to the high illiteracy levels in the region, many people continue to abide by the customary land laws (Kasanga, 2002). The next section examines the post-independence land tenure reforms and their effects on resource access and control by a broad range of actors.

\subsubsection{Land administration after Independence: Chiefs or Government?}

Several land management reforms were put in place between independence (1957) and $1968^{3}$ to regulate the land tenure system. These reforms were intended to bring about a shift in land administration from the customary system to a government controlled and subsequently, a monetised system (Kasanga and Kotey, 2001). The reforms were also intended to bring about equity and equal rights to land for all. However, as Obeng-Odoom (2014) states, the idea of the "untouchable chief" and his land was not completely eroded after independence. Nkrumah's government disempowered the chiefs but retained the ideology of collective ownership

\footnotetext{
2 The Administration Ordinance (CAP III), 1902; The Land and Native Rights Ordinance No. 1, of 1927, the Land and Native Rights Ordinance, 21 November 1931(Cap 147), 195 and the mineral Ordinance 1936(Cap 155) revised in 1951.

${ }^{3}$ The state land Act, 1962 (Act 125); the Administration Lands Act of 1962 (Act 123). The state property and contracts Act 1960(CA6) transferred all land vested in the Governor General to the President. The state was empowered to acquire land compulsorily in the country. All Northern land was vested in the President. In the South, the Ashanti and Akim Abuakwa stool lands were vested in the President when it was discovered they used stool money to support the rival political party (Ashanti stool Act 1958 and the Akim Abuakwa stool Revenue Act $\mathrm{N}^{0} 78$ of 1958). By extension the vesting of power was later extended to the rest of the country by the Stool Lands (validation of legislation) Act $\mathrm{N}^{0} 30$ of 1959 and Stool Lands Act 1960 (Act 27). The Concession Act, 1962 vested all timber trees in the government on trust for the stool even though it was later repealed.
} 
of land which, giving the importance of chiefs to the collective, leaves their authority over lands undiminished (Amanor, 2005). Thus, although Nkrumah (1973: 35) was of the view that "the chieftaincy, in common with other human institutions, cannot remain static, but that it must in large measure adapt itself to the changing requirement of the changing time", only the chiefs allodial rights to lands were shifted to his government (Obeng-Odoom, 2014).

Early research in the 60's and 70's portrayed colonial governments as external actors governing and exploiting African societies according to the political and economic interests of their home governments (Berry, 1992). But authors including Bates (1983) and Jessop (1977) have argued that it was not only colonial governments who benefited from the African states. They explained that governments are made up of complex institutions with different individuals or group of individuals with different interests. Thus, a political institution can be viewed as a forum through which people channel their preferences for a social outcome. Even though the government manages the national economy, it can only retain power through satisfying the interests of other key sectors within the domestic political economy. For example, in the case of Ghana, land administration policies enacted by the state can only work efficiently if the interests of chiefs and other senior administrators are satisfied. The idea of disaggregating the state, conceptually speaking, has been borrowed by many students of political economy and social history in explaining how culture shapes social and economic processes. Paaga (2013) states that land as a resource arouses territorial instincts from different individuals and groups, with different agendas or interests which could sometimes lead to disputes.

After Nkrumah was overthrown in 1966, the land tenure system in Ghana underwent several reforms with the most recent one made by the 1992 constitution (Kasanga, 2002). Currently, there are 86 legal land instruments ${ }^{4}$ in Ghana. These legal instruments operate alongside customary laws, thereby making the administration of land in Ghana more complex (Ministry of Land and Forestry, 2003a). For example, Article 271(1) of the 1992 constitution states that "all stool land is vested in the appropriate stool or skin on behalf of and in trust for the subjects of the stool or skin in accordance with the customary law and usage." This implies that the traditional authorities take all management decisions and exercise powers that deal with the rights to own, sell, receive payment, manage, and decide on allocation terms and price for a plot. The above article overlaps with Article 267 (2) and (6) that sets up the Office

\footnotetext{
${ }^{4}$ Local Government Act 1993(Act 462); Town and Country Planning Ordinance of 1945(CAP 84); Fourth Republic Constitution (L. I) 1241; National Development Planning Commission Act 1994 (Act 479); National Development Planning (Systems) Act 1994(Act 480); Land Commission Act, 2008(Act 767) which repealed the Lands Commission Act 2000 (Act 483). Constitution of the Republic of Ghana, 1992; Administration of Stool Lands Act, 1994(Act 481) which repealed the Administration of Stool Lands Act; State Lands Act, 1962 (Act 125); Deeds Registration Ordinance of 1883; Land Registry Ordinance of 1895; Land Registry Act 1962 (Act 122); Land Title Registration Law, 186 (PNDCL 152); Land Title Regulation, 1986 Legislative instrument.
} 
of the Administration of Stool Land (OASL) to work on all financial matters on stool land including disbursement of all stool land revenues like rents and royalties, which traditional authorities do.

Several authors including Kasanga (2002), Kasanga and Kotey (2001), and Ubink (2008) have alluded to the dual land ownership system in Ghana between the state and the customary authorities. As mentioned earlier, $80 \%$ of lands in Ghana is owned by the traditional authorities while only $20 \%$ is owned by the state. It is difficult to know what percentage of the land belongs to private holders since it is hard to determine whether those lands are customary freeholds as in Article 267(5) or not. Da Rocha and Lodoh (1999) are of the opinion that as of 7 January 1993, no one could acquire a freehold interest in stool land. Gyan (2005) disagrees and argues that this article does not prohibit the grant of customary freehold in stool land and family land where the grantee is a subject of the land owning stool.

The above section shows that ambiguities in the land tenure system in Ghana have led to many overlaps in land administration between traditional and state authorities, and even among different state land agencies. These conflicts and how the uneasy relationship between the state and the chieftaincy institutions have shaped the present dual land tenure system in Ghana are further discussed in chapter 5 . The overlapping and conflicting land statues are exploited by farmers in their struggle to gain access and control over lands for agricultural activities. Chapters 6 \& 7 discuss this.

Another important resource whose access poses serious challenges to farmers is water. The next chapter briefly examines the customary and statutory laws that regulate access to, and the use and control of, of different water sources in Ghana.

\subsection{Who owns water?}

Water is one of the most valuable natural resources for agricultural, industrial, health and hydropower (Opuku-Agyemang, 2005). However, there is a scarcity of water in many parts of Sub-Saharan Africa according to van Koppen (2003), especially in the semi-arid and arid areas where rainfall is spatially variable and unpredictable (Gichuki et al., 2000). On the African continent lakes, rivers, and vast wetlands are limited. However, ground water is largely untapped. Mwanga (2003) and Lipton and Litchfield (2002) estimate that only 1 to $5 \%$ of cultivable land in Africa is irrigated compared to 30 to $50 \%$ in Asia. According to FAO (1995), of the total 212 million hectares of land under cultivation in Africa, available land and water resources can only allow for an eight-fold increase in cultivation on just $2.4 \%$ of the total farm lands.

Agricultural growth has long been considered the engine of Sub-Saharan African economy as it employs $65 \%$ of Africa's labour force and accounts for $32 \%$ of the gross domestic 
product (Chauvin et al., 2012). According to the World Bank (2013) fact sheets, African agriculture has improved since the 19th century, but its productivity level is still the lowest in the world. Koning (2002) argues that if the African governments do not protect farmers from trade policies and low international prices which are imposed by international financial institutions, limited progress will continually be made in the agricultural sector in Africa. Per capita availability of land in Africa has decreased from 0.5 ha to 0.3 ha between the 1970 s and the $1990 \mathrm{~s}$. Landlessness is currently a major problem in many African countries (Benneh, 1996). Climate research suggest that in 2015, 1.8 million people were already living in countries or regions with absolute water scarcity and by 2030 , nearly half of the world's population will be living in areas with extreme water shortage (Falkenmark, 1989; Unesco World Water Assessment Program, 2012).

Water stress is now considered extreme in Africa and the Middle East, with the most adversely affected areas in the Gulf nations (Maplecrof, 2013). Many urban areas in Africa in the 1970's used ground water sources like boreholes, springs, and wells as their primary source of water and most of these sources in Sub-Saharan Africa were mostly from interbasin water transfers (United Nations, 1973). With increasing urbanisation and population growth, many water areas will be drained, and a decrease in groundwater will likely lead to an increase in the use of surface water. According to Benjaminsen and Lund (2002), international pressure on African states to make water more productive by commodifying it has resulted in different options. The introduction of a water reform through the "user pays principle"' in Zimbabwe for example, was resisted its citizens who believed that water should be shared freely (Derman and Hellum, 2007).

According to news media outlets including Peace FM Online ${ }^{5}$, Pulse ${ }^{6}$, and Ghanaweb.com ${ }^{7}$, Ghana will face a severe water crisis in 2025 that will result in a reduction in its water cover from $70 \%$ to $40 \%$. This crisis is likely to be caused by climate variability and change, increasing pollution of water bodies, and human activities such as forest degradation, illegal mining, and changing land use patterns. Therefore, an increase in the Ghanaian population will most likely exert pressure on the water resources of the country and increase conflict and tensions between different water users. Since no national water policy existed before the 1992 Constitution, a Water Resource Commission (WRC) was set up under Article $269^{8}$ of the

\footnotetext{
${ }^{5}$ http://www.peacefmonline.com/pages/local/news/201605/280255.php. This document was retrieved, on the, $11^{\text {th }}$ of August, 2016.

6 http://pulse.com.gh/news/climate-change-scientists-warn-of-water-crisis-in-ghana-id4888282.html. This document was retrieved, on the 11st of August, 2016.

7 http://www.ghanaweb.com/GhanaHomePage/NewsArchive/Ghana-s-water-crisis-will-worsen Geographer-415703. This document was retrieved on the $11^{\text {th }}$ of August, 2016.

${ }^{8}$ (1) Subject to the provisions of this Constitution, Parliament shall, by or under an Act of Parliament, provide for the establishment, within six months after Parliament first meets after the coming into force of this Constitution, of a Minerals Commission, a Forestry Commission, Fisheries Commission and such other Commissions as Parliament may determine, which shall be responsible for the regulation and
} 
1992 constitution to set water policy in Ghana. This statutory body is charged with coordinating, regulating, and managing water resources according to section $2^{9}$ of the Water Resource Commission Act 522 of 1996 . The commission can grant, limit, or suspend a right already given depending on the circumstance. The control of water resources is also vested in the President on behalf of the people of Ghana (Section 12) ${ }^{10}$. Although the Water Resource Commission has been in existence for quite some time, it has not achieved much in the way of formulating concrete policies with regards to water rights. However, before the creation of the WRC there were a number of independent water agencies in Ghana. They include the Ghana Water and Sewerage Corporation (GWSC), the Volta River Authority (VRA), and the Irrigation Development Agency (IDA). The Ghana Water and Sewerage Corporation was setup in 1965 and charged with providing, distributing and conserving water for domestic and industrial purposes according to section 2 of the GWSC Act 310, 1965. It was also charged with developing long term sewage and water plans for the country. Under LI 1233 (section 1-20 of the GWSC Regulations), this body was entitled to all lands including private ones provided they are necessary to the implementation of its mandate which includes erection, inspection, and repair of sewage plants.

However, the GWSC fell short of providing sufficient water to the rural areas and as a result, Act 564 was created in 1998 which mandated the Community Water and Sanitation Agency (CWSA) to provide water to rural the areas. The agency was expected to include women in its operations since they were in closer contact with water-related domestic activities than men. It was also expected to work in collaboration with the Environmental Protection Agency (EPA) and the District Assemblies (DA) to promote a participatory approach to water provision in the rural areas and ensure water safety and sustainability. These provisions were provided in section 10(1) and 10(3) c, d, e of the Local Government Act 462 of 1993, which

management of the utilization of the natural resources concerned and the coordination of the policies in relation to them.

(2) Notwithstanding article 268 of this Constitution, Parliament may, upon the recommendation of any of the Commissions established by virtue of clause (1) of this article, and upon such conditions as Parliament may prescribe, authorize any other agency of government to approve the grant of rights, concessions or contract in respect of the exploitation of any mineral, water or other natural resource of Ghana.

9 (1) The Commission shall be responsible for the regulation and management of the utilization of water resources and for the coordination of any policy in relation to them. (2) Without prejudice to subsection (1) of this section, the Commission shall - (a) propose comprehensive plans for the utilization, conservation, development and improvement of water resources; (b) initiate, control and coordinate activities connected with the development and utilization of water resources; (c) grant water rights; (d) collect, collate, store and disseminate data or information on water resources in Ghana; (e) require water user agencies to undertake scientific investigations, experiments or research into water resources in Ghana; (f) monitor and evaluate programs for the operation and maintenance of water resources.

10 The property in and control of all water resources is vested in the President on behalf of and in trust for the people of Ghana. 
was created to establish close ties between the water agency, the district assemblies, and the unit committees.

Mensah (1999) indicates that water rights in the customary system vary across the country. The most important sources of water in the various communities include wells, streams, rivulets, and rivers. In the Akan customs rivers, lakes, and seas are all vested in the stool (Illenu, 1962). In times of scarcity, even water owned privately becomes a common property and it is shared by all members of the community (Opuku-Agyemang, 2005). In some communities, surface water is public property under the trusteeship of the traditional leader (which can be the king or the chief), who holds the water in trust for the people. In other communities, water is said to have no owner. There are community wells (dug by the community for collective use) and private wells (drilled by individuals on private lands). Drilling is a particularly expensive service and well water is often unaffordable for many in the rural areas. The price of a well ranges between 250 to $400 \mathrm{Cedi}^{11}$ and the cost of a bucket of well water ranges between 10 and 40 pesewas, which can be expensive for the rural poor.

Chiefs, elders, and earth priest are usually the ones who control, manage, and regulate water use: they select days within the month or year on which sacrifices are made to cleanse the water and rules on water use are reiterated (Ofori-Boateng, 1977). Ofori-Boateng also states that it remains unclear whether customary laws treat groundwater on private lands as part of the property of the land's owner.

So far, this section has explained how the laws regulating water use for farming and other activities vary from community to community. Water used mainly for agriculture is controlled by traditional authorities and the government. Unlike dugouts and streams, irrigated water and pipe or portable water cost money to obtain. In the semi-arid areas that are the main focus of this study, there is a heightened level of water scarcity which has caused many dry season farmers to use water from ditches, sewers, streams, and dugouts despite the associated health risks. Also, because most of the dry season vegetable farmers are probably poor, they are mostly only able to access pipe or potable water through negotiations with non-governmental organisations and research institutions as discussed in chapters 6 and 7 . Another important resource (in addition to land and water) whose access poses a challenge to many farmers is vegetable seeds.

The next section examines the importance of seed in the African agricultural system and how vegetable farmers gain and control access to them. It also hints to the global seed discourse and the developing agro-seed business in Africa in order to update the reader on some of the recent developments in the seed discourse in Africa.

${ }^{11}$ According to the OANDA currency converter, 1 new Ghana Cedi was 0.22 Euro in 2015. 


\subsection{Which seed and why?}

"Don't judge each day by the harvest you reap but by the seed that you plant" (A poem by Robert Louis Stevenson).

The fundamental unit of agricultural production, as Etwire et al. (2013) argue, is seed. They determine the yield potential of a crop and the right seed can increase productivity even without other inputs such as fertilisers and pesticides (Cromwell, 1990). It may come in the form of a "dry seed" (as in the case of jute mallow (Corchorus olitorius)) or a cutting (as in a cassava cutting (Manihot esculenta)) (Jaffee and Srivastava, 1992). Etwire et al. (2013) and Niangado (2010) argue that seed is not only the most important production input, but it is also the cheapest in Ghana and Sub-Saharan Africa in general. In Ghana, farmers largely depend on their preserved seeds and are reluctant to buy hybrid or improved -open pollinated- seeds. This is also compounded by the poor seed delivery system in the country (Amanor, 2011).

Seed production, processing and distribution in the global North is mostly done by its private sector. Its public sector on the other hand undertakes such initiatives as seed research and development and provides other services including seed certification, seed crop inspection, and fair-trade practices. In developing countries seed production, processing, and distribution were done by their governments in the 1960's and the 1970's (Srivastava, 1990). During the structural adjustment period (1080's), the seed system in Sub-Saharan Africa came under a lot of pressure to privatise. A lot of money was invested in large national farms with no significant improvement in food productivity. Privatisation of some public sector organisations like the seed company took place (Amanor, 2010) which severely reduced funding for government research. This played a role in reducing the capacity of government research institutions to breed climate resilient vegetable varieties (Afari-Sefa et al., 2012). The technical know-how for vegetable seed production is inadequate compared to that involved in the production of cereal seeds or field crops in both the formal and informal seed systems in Africa (Tabor and Yesuf, 2012).

There are mainly two parallel seed systems in many African countries. A formal system led by the state and supported by international non-governmental organisations (INGO's). This system has clear rules and regulations on seed production, certification, and distribution. Seeds under this system are expected to be registered and to meet the quality standards set by the different countries. Presently, regional seed harmonisation workshops are taking place in the different blocks to harmonise seed laws and even seed quality standards in the different countries found within a particular region. For example the Conseil Ouest et Centre Africain pour la Recherche et le Développement Agricoles (CORAFMECARD) recently issued an official release to the Economic Community Of West African States (ECOWAS), the Union 
Économique et Monétaire Ouest-Africain (UEMOA), and the Permanent Inter-State Committee for Drought Control in the Sahel member states requesting that the ECOWAS publication be published in their gazettes so seed regulations can be enforced in all the countries concerned $^{12}$ based on Article 88 of the ECOWAS seed regulations.

The informal system on the other hand, is a traditional system in which farmers select and preserve -post-harvest - the best seeds for use the following season or seasons. More than $80 \%$ of seeds used in the African agricultural settings are informally produced by farmers (Jonge and Munyi, 2016). Distribution of the seeds usually takes the form of barter, exchange, donation, and even gifts. Therefore, farmers are both the producers and the consumers of seeds under this system (Ayana et al., 2014; Jaffee and Srivastava, 1992; Niangado, 2010). In Tanzania, 70 to $75 \%$ of seed is produced by the informal sector while just $25-30 \%$ is provided by the intermediate and formal sectors (Afari-Sefa et al., 2013). Intermediate seed systems are usually a group of individuals or community members considered model farmers who are trained to produce seeds using formal laws. In Ghana, they have been integrated into the formal seed system and provide seeds certified by the state (Amanor, 2010). The utilisation of improved seed varieties and hybrid seeds is lower in West and Central African states than in East and Southern African countries like Kenya, Malawi, Zimbabwe, and Zambia. The reason for this variations in seed use across Africa is because the private seed production and market sector in East and Southern Africa are more developed than in West and Central Africa.

The commercial seed industry in Ghana was first established in 1958, with the aim of producing and multiplying hybrid maize seeds and subsequently, open-pollinated seeds (Amanor, 2010). The expansion of commercial seed production was part of the Green Revolution (GR), which was focused on raising the demand for certified seeds and other technological inputs in African countries like Ghana. Simultaneously in the Global North, big agribusiness started to acquire seed varieties produced by local farmers through intellectual property rights (IPR) arrangements, promulgated and strengthened by patent regulations and the traderelated aspects of the World Trade Organisation (Amanor, 2010). The Green Revolution was unsuccessful in Africa and its failure is largely attributed to the reluctance by local farmers to embrace new technologies they deemed unsuitable for the kinds of farming methods they practiced.

In the late 1980's, one of the requirements for Ghana's structural adjustment package was the privatisation of the seed sector (Amanor, 2010). The use of commercial or certified seeds was seen as the panacea for farmers' problems and food insecurity just like the Sasakawa 2000 project when it was first introduced. During this period, concerns about the erosion

\footnotetext{
${ }^{12}$ Burkina Faso, Cape Verde, Chad, Gambia, Guinea Bissau, Mali, Mauritania, Niger, Senegal, Benin, Cote d'Ivoire, Ghana, Liberia, Nigeria, Sierra Leon, and Togo.
} 
of seed diversity resulted in the rise of civil society organisations and NGOs lobbying for farmers' rights to their own seeds. They include the Rural Advancement Foundation International (RAFI) - known today as the ETC Group (Action Group on Erosion, Technology and Concentration) - and the Genetic Resources Action International (GRAIN). GRAIN proposed the strengthening of the informal sector's seed research capabilities through farmers' associations and NGOs instead of adopting the Green Revolution`s approach which undermined the ability of farmers to manage their ecosystems and biodiversity (Amanor, 2010).

With the introduction of the Structural Adjustment Program (SAP), agricultural policies were made more free market friendly. Smallholder farmers were integrated into projects in which they benefited from the introduction of new inputs but they were also expected to conform to a top-down approach explained in Koning (1986). Cooperation and extensive linkages with multilateral organisations and state institutions like the Canadian International Development Agency (CIDA), the German Technical Assistance Cooperation (GTZ), Ghana Grain and Development Project (GGDP), Savannah Agricultural Research Institute (SARI), and the Council for Scientific and Industrial Research and the Crop Research Institute (CRIR-CSI) were developed to address issues relating to pests, diseases, resistance, acceptability, and the adaptability of crops to local climatic conditions (Amanor, 2010). The agricultural industry, particularly the trade in fertiliser, was heavily privatised in Ghana. The liberalization of the foreign exchange market and a $25 \%$ drop in the value of the local currency resulted in high interest rates of 30 to $40 \%$ on agricultural loans from banks. The price of fertilisers was later increased which negatively impacted demands by farmers (Amanor, 2010).

The seed sector is receiving a lot of attention from researchers and policy makers due to ongoing debates about seed sovereignty, the implications of intellectual property rights for Genetically Modified Organisms (GMOs), and the conservation of agrobiodiversity. Understanding seed circulation is complex since farmer seed systems are embedded in social relations and institutions that constitute the socio-economic and political fabric of community life. The existence of a dual seed system in Ghana has opened avenues through which farmers can negotiate access to seeds with NGOs, research institutions, and other actors. In this study, I am interested in the different relations and interactions farmers exploit in order to access and control seed for their agricultural practice. These are explored in detail in chapters 6 and 7 .

This chapter has focused on the historical processes through which resources are accessed, managed, and controlled in Africa and Ghana in particular. It has shown that customary and statutory laws co-exist but do not always have the same agenda in administering these resources due to the different interests of the various institutions and individuals implicated in these systems. The struggle for access and control of resources involves different actors including individuals, private institutions, the state, and international agencies, each relying on different customs and concepts such as territoriality, belonging, and community for legitimacy 
and authority (Lund and Boone, 2013). This has led to changes in the nature of power relations and has reshaped access to resources over time as new claims of legitimacy, rights, and benefits are reconstructed and transformed (Ibid). Ambiguity resulting from these overlaps has been exploited by farmers to negotiate and gain access to and control over resources for vegetable farming as explained further in chapters 6 and 7.

\subsection{Structure of thesis}

The introduction to this thesis previews the reader on how access and use of resources in Ghana - and Africa as a whole- have been shaped and reconstructed through different historical moments and geographical spaces. It argues that access and control over resources by various actors have never been static, but are always changing. These changes are due to changing socio-political and economic circumstances and also varying interests of actors and institutions at various times. Presently, urbanisation, population growth, and increasing land markets are also influencing access to and control of resources for vegetable production. The introductory chapter hints at how vegetable farmers negotiate with each other and with other actors in this present socio-political environment to gain access and maintain control over resources for dry season vegetable gardening.

Chapter 2 deals mostly with the theoretical framework of this thesis. Concepts of power relations, authority, legitimacy, governance, networks are contextualised and explained in this chapter. It employs theories and concepts such as governmentality- which explains how subjects are governed from afar and how the state and individuals govern each other. The concept of political ecology is used to further understand the asymmetrical power relations in resource use and control and how people interact with their environment and with each other. Resource access studies will give a better understanding of how actors gain the ability to benefit from "things" which can constrain or enable access. Science and technology studies also explain how social and technical configurations interact to solve problems. This techno-graphic approach is also used to describe how human and non-human "actants" build and maintain relationship "networks" in order to access and control vegetable farming resources. The processes of resource access and control are framed in the context of these theories. Through them, we seek to understand how farmers manipulate the activities of different social actors and institutions to access and control resources for vegetable production. For example, these theories will help us understand how power shifts over space are manipulated by farmers to tailor their relations with actors which can help them achieve their interests. Chapter 2 also explains the role of legitimacy and public authority in legalizing claims in the midst of asymmetrical power dynamics in resource access. The theories are also used to explain how farmers "shop" for different forums in the same or different institutions in order to legitimize their claims to resources. They are also used to explain how an actors' repertoire of knowledge, 
technology, social identity, market, and capital are used to legally or illegally maintain and control access to resources for vegetable production.

Chapter 3 situates the study in a geographical, socio-political, and demographic landscape. It presents the author's methods and reflexivity during the research process. It also presents the author's data collection methods, sampling techniques, and analysis in a way that allows for the replication of this work elsewhere.

Chapter 4 examines the emergence of the Dagomba people and how they came to settle in the Northern Region of Ghana. It argues that the British economic policy which turned the Northern Region into a labour reserve to extract resources in Southern Ghana has contributed to the present semi-subsistence agricultural system found in the region. In addition, the lack of collaboration and synergy between different institutions and actors involved in improving the agricultural system during colonial and postcolonial times have contributed to the low levels of progress and innovation in the agricultural sector of Northern Ghana. Specifically, colonial urban agricultural policies, based on outdated laws and special interests, continue to shape the fate of urban agriculture in present-day Ghana.

Chapter 5 gives a historical overview of the different land administrative governance systems in the Northern Region of Ghana. It discusses the emergence of chieftaincy systems from the pre-colonial era and explains how it was sustained by the colonists through indirect rule. It also examines how shifting power relations between the state and traditional authorities in administering land between the colonial and postcolonial eras has reinvented the traditional land laws and constructed the existing dual land tenure system in Ghana. Ambiguities resulting from questions of legitimacy and control over land administered by state and traditional authorities have created spaces in which farmers negotiate access and control over resources for agricultural activities.

Chapters 6 and 7 provide the empirical results of this thesis. They examine the different socio-political and institutional processes through which farmers negotiate, cooperate, coordinate and even manipulate 'elements' in their social settings in order to gain access and maintain control over resources for vegetable cultivation. The chapters also show how the uneasy relationship between traditional and state authorities explained in chapter 5 creates gaps within which farmers negotiate for resource use and control. In addition, because discourses on urban agriculture are built on outdated planning laws, many non-governmental organisations and research institutes are collaborating with farmers to gain and maintain access to resources for urban gardening. Furthermore, the chapter argues that unless care is taken, the absence of synergy between actors and farmers to promote urban agriculture will result in an unsustainable practice as discussed in chapter 5 of this thesis and by Nchanji et al. (2017).

The concluding chapter highlights the contribution of this study to theory and science. It explains how women's access to resources like land has changed over time as a result of 
influences of global development discourses on gendered agriculture. The findings are situated in the global context of resource access politics/debates in Africa. The chapter also highlights what is novel about this study. 


\section{Chapter 2 - Theoretical Framework}

\section{Introduction}

Understanding the socio-political configurations through which resources and commodities are channeled into urban gardening and the different bundles of power drawn upon to access and maintain them require an analytical approach that probes the very provenance of social relations in the African society. The theoretical framework employed for this empirical task incorporates governmentality studies, political ecology, resource access theory and science and technology studies. Governmentality studies explain how different governance systems are created or recreated as a result of government interventions in resource access and control. Political ecology is used to show how shifts in power relations between actors over time and space play out as they attempt to gain or control various resources. Resource access theory explains how actors use social relations, markets, knowledge, social identity, and historical events to enable their access to resources and maintain control over their use. Science and technology studies are used to understand how different actants, human or non-human, seek to build and maintain networks through which they can gain access and control over resources. This chapter analyses these theoretical frameworks as employed by the author for the analysis of this thesis.

This chapter is divided into three sections. Sections 2.1 and 2.2 further explore the governmentality and political ecology literature in order to gain a better understanding of government intervention and its nature and how shifting power relations between actors' manifest in resource access and control. Section 3 examines how actors negotiate and stake claim to resources through alliances and politico-legal discourses. It also examines how socio-political changes over time alter the nature of power and the different forms of access to resources.

\subsection{Effects of ambiguity and constructs}

As discussed in the previous chapter, land, water, and seed are indispensable resources to agricultural production. Access to these resources are continuously being shaped and negotiated in many places including Ghana (Berry, 1992; Elmhirst, 2011). Gaining and controlling access to a resource depends on one's position in society over a given period of time. According to Ribot and Peluso (2003: 154), "people and institutions are positioned differently in relation to resources at various historical moments and geographical scales." Thus, when the role or powers of individuals and institutions change over a socio-political and historical period, the power to access resources also changes. Foucault (1991) defines power as a regime of truth, where truth is negotiated and redefined through a flux of political and economic ideologies 
influenced by the media and educational system. Here, power is constituted through an accepted form of knowledge which conditions an actor's' access to resources. Individuals or institutions can draw from different sources of power (political or economic) to gain or give legitimacy to one governance system or another depending on their interests (Ribot and Peluso, 2003).

Resource access, use, and management have been constructed and reshaped through programs, projects, and policies implemented by state and international and national non-governmental organisations. These interventions are referred to in this study as government interventions not to suggests they are all done by a government in the political sense, but rather because they are intended to govern the behavior of people through calculated technologies (Foucault, 2001). Governmentality refers to how the state governs people from afar. But it can also be seen to include how individual and group actors interested in changing a society shape the behavior of its people from afar as the effects of the introduction of a drip irrigation technology and solar plants by a host of non-governmental organisations shows in chapters 6 and 7.

Government interventions are not always good for farmers and in many instances, they are not successful at achieving the goals for which they were initiated (Li, 2007a). For example, the Land Administration Program was introduced to provide fair and equal access to land for every Ghanaian. But as shown in chapters 5,6 , and 7 this program has instead created a space in which chiefs and land developers are appropriating land for their personal benefits. This has denied the poor and the marginalised fair or equal access to land as argued by Obeng-Odoom (2014).

To tease out how these power relations are implicated in the struggle for access to resources, this author employs a political ecological approach which deals with the power relations inherent to the use of land by individuals and how those individuals interact with each other and with their environment. The author uses Callon's (1986) concept of translation and Latour's (1984) notion of power (from science and technology studies) as tools with which to illustrate the processes by which actors convince and enroll other players in their quest for access and control over resource. Furthermore, I will show how shifts in power relations are manipulated to achieve personal interest (Callon, 1986; Latour, 1984; Law, 1986). 


\subsection{The Political Ecology of government interventions}

'Only 'beyond the state,' it appears can life worthy of free human individuals begin" (Rose and Miller, 2010: 271).

Government intervention in this study refers to the use of technology and knowledge to govern human behavior by various actors including, but not limited to, the state. Political ecology is the lens through which power relations between different actors - in their struggle for access and control over land, seed, and water resources - is analysed. These power dynamics is not limited to asymmetrical relations in resource distribution and benefits, but also includes relations which are relied upon to bring about change. Where there is plurality of interest over resources, one's profit can sometimes be another's loss (Blaikie, 1985, 1995; Bryant, 1998; Escobar, 1999; Paulson et al., 2003; Robbins, 2012; Watts, 2003; Wolf, 1972). However, this is not always the case as seen later on in this study.

Interventions have had both direct and indirect effects on land use patterns, resource disputes, and tenure transformations. The intervening agents in the Northern Region include the Tamale Metropolitan Assembly (TaMA), traditional authorities (chiefs), Savanna Agricultural Research Institute (SARI), University for Development Studies (UDS), government land agencies, farmers, and NGOs including the Urban Agricultural Network (Urbanet), New Energy, United States Agency for International Development (USAID), and the Trento cooperative. In addition, other actors and institutions like agro-dealers and private landowners are also implicated in government interventions in the Northern Region. The plurality of actors, organisations, and institutions means divergent interests. These divergent interests are sources of conflict between the various actors. However, many have managed to cooperate with each other in order to advance their mutual goals.

The different interventions by these actors in relation to dry season vegetable gardening are important political processes studied by this author. The concept of access is an important building block for this analysis. The interventions which will be central to this thesis are referred to as "governmental." For a better understanding of governmental interventions, it is necessary to delve a bit deeper into the governmentality literature.

\subsubsection{Government interventions, practices, and the notion of Governmentality}

Governmentality has historically been a specific art of government. In some views, it is a particular way of governing that is closely linked to notions of sovereignty and discipline (Foucault, 1991; Inda, 2005). According to Foucault (1991), governmentality is not a replacement for other forms of government but rather it is "a triangle; sovereignty-discipline-government, which has as its primary target the population and its essential mechanism the apparatus of security." 
Foucault explained what a sovereign government is in his interpretation of Machiavelli's The Prince, describing it as a situation in which the prince has the ultimate power over the people and his sovereign territory. The exercise of power by government was through force and violence as situations demand. He distinguished this form of government from a modern system of government using Guillaume de la Pierriere`s Mirror Politique in which a government governs its citizens through subtle power from afar; that is, through calculated techniques and rationality as opposed to the use of visible force or violence (Foucault, 1991). Some academics use the term governmentality as a theoretical base or as an analytical tool to understand political processes in government interventions ${ }^{13}$ (Foucault et al., 1991; Li, 2007b; Li, 2007a; Sending et al., 2006). This author uses the term governmentality in a similar sense. In common parlance the word "government" refers to aan organ, tat carried out activities of the state and backed by political powers. In Foucault's 2001 lecture on governmentality, he attributed the erroneous perception of state and government as closely linked to historical processes in the fifteenth and sixteenth centuries Europe when the state became "governmentalised' (Foucault, 2001). He explained that government came to be used as an exclusive construct of the state after the 'governmentalisation of the state' (Foucault, 2001).

The extent of the link between state and government notwithstanding, there is a link nonetheless. Government is internal to the state, for it is within the state that it exercises power and control over its subjects. In a broad sense however, government refers to the management, control, direction, and guidance of oneself and a group of people (Dean, 2010; Li, 2007b; Rose et al., 2006). This implies that it is not to the state only that the concept of government applies; it transcends the state as much as it can be done at the sub-state level. It is a mechanism that cuts "across domains that we would regard as separate: the state, civil society, the family, down to the intimate details of what we regard as personal life" (Dean, 2010: 10). Government as the conduct of the conduct in the Foucauldian sense is analysed by Li (2007b: 5) as an "attempt to shape human conduct by calculated means." It deals with how individual and group behavior is shaped, guided and directed in a particular direction by different actors using different techniques, practices, and knowledge (Foucault, 1991, 2001). The term 'government' as related to the phrase 'conduct of the conduct' means to lead, direct, guide, or perform some sort of calculation - to conduct oneself in a particular manner, - the art of comportment. Government in the Foucauldian point of view is pluralistic. Dean (2010: 18), adds to this by stating that:

\footnotetext{
${ }^{13}$ Dean (2010) explains the plurality of governmentality and proposes calling the latter "analytics of government" to distinguish it from the historical meaning of governmentality. However, the use of the "analytics of government" has not been widely adopted as many authors still prefer to use the word governmentality, such as Merlingen (2006: 183) who says other labels like analytic government are clumsy and that using governmentality theory "may actually ease the dissemination of the approach in International Relation and European studies", hence her disregard for conventional labelling.
} 
Government is any more or less calculated and rational activity, undertaken by a multiplicity of authorities and agencies, employing a variety of techniques and forms of knowledge, that seeks to shape conduct by working through the desires, aspirations, interest and beliefs of various actors, for definite but shifting ends and with a diverse set of relatively unpredictable consequences, effects and outcomes.

The meaning attached to government has an implication for the way the state is approached in this study. Here, the state and the different institutions (political, social, economic, cultural) are all considered to be one - that is, they are all involved in the government of the people. These institutions consist of state officials, researchers, NGO's, and traditional authorities who, as Li (2007a) states, are trustee and participants in government. While government practices linked to state, national and international actors is important and is discussed in this paper, those of chiefs and other traditional leaders deserve particular attention since they have a closer impact on the people. Thus, despite literature on the importance of the state to citizens` lives, Trioullot (2001) and Ferguson and Gupta (2002) call for a 'common frame' where analytically non-state actors should be viewed as operating on the same level as the state. Foucault's concept of governmentality provides this common frame.

Ferguson and Gupta (2002) have adopted transnational governmentality as an extension of the Foucauldian notion of governmentality to explain not just the plurality of national actors, but also the new complex alliances which are being introduced on a global scale and beyond the state.

These include not only new strategies of discipline and regulation, exemplified by the WTO and the structural adjustment programs implemented by the IMF, but also transnational alliances forged by activists by complex networks of international and transnational funding and personnel (Ferguson and Gupta, 2002: 113).

The significance of the term transnational governmentality is felt in the idea that government interventions do not originate only out of the efforts of a single governing institution or agency but more often from a transnational collaboration or 'partnership' with other different agencies. The Administration Land Project for example, emerged from a partnership between the World Bank, Department for International Development (DFID), Canadian International 
Development Agency (CIDA), Kreditanstalt fur Wiederaufbau (KfW), German Technical Assistance Corporation (GTZ), Nordic Development Fund (NDF), Government of Ghana and chieftaincy institutions. The concept of transnational governmentality was coined by Ferguson and Gupta to portray an extension of a modern government in which grassroots or local organisations are linked to and with international organisations to the exclusion of the state. This, however, does not imply that local or transnational actors are superior or are always at the winning end of any conflict or fight "or that national states have become incapable of exercising their authority over localities" (Ferguson and Gupta, 2002: 122).

This study focuses on how government interventions govern the people from afar by shaping the way they interact with each other and with socio-political and economic institutions or agencies in relation to their access, maintenance, and control of resources like land, water, and seed. This study touches upon on government interventions like the Land Administration Project, which is rooted in the relationship between the chieftaincy institution and the state dating back to the colonial time period. Other government interventions and their effects on resource use and access are discussed in chapters 6 and 7.

According to Scott (1998), the state easily governs the people by making them and their environment 'legible' through what he refers to as 'state simplifications;' that is, the use of planning schemes and cadastral maps to detail land boundaries and ownership. This is employed by the state to gain political control over land administration. This strategy is implicated in the scramble for land in the Northern territories (Northern Ghana) as discussed in chapter 5. In that particular episode, we European states gained political control over their colonies in West Africa, and Ghana in particular, by appropriating the indigenes into categories that eased administration. The people colonized were first classified into different tribes and then placed under 'centralized traditional states.' After that, an administrative system was created where the head of these states, referred to as chiefs, were under colonial administrative control. In this manner, the colonial governments were able to rule the people indirectly through their handpicked chiefs. After independence, development projects including the Land Administration Program were introduced. The justification for them was that they were joint development projects involving a plurality of actors and institutions whose aim was to promote the common good as stated in development discourses ( $\mathrm{Li}, 2007 \mathrm{a})$.

These partner-driven projects were influenced by a can-do spirit that with government at the helm. Built on the notion of the will to improve. Hence, government interventions were branded development projects under the 'we can improve' spirit as explained in Li (2007a), or what Dean (2010: 44) calls the "utopian element of government." The will to improve is seen in Foucault's exploration of the different historical forms of rule and in Li's book titled the will to improve. Foucault (2006: 140) elaborates on this idea when he states "in contrast to sovereignty, government has as its purpose not the act of government itself, but the welfare of the 
population, the improvement of its condition, the increase of its wealth, longevity, health." The role of government as the improver of the welfare of the people can be viewed as paternalistic and expansive ( $\mathrm{Li}, 2007 \mathrm{a})$. However, government interventions are not always welfare improving (Li, 2007a). Li, (2007a: 1) argues that some intervention programs are "intertwined with other processes and relations, set the conditions for some of the problems that exist today" even though they also bring about positive changes that people desire. Hence, a broad, critical analysis is sometimes necessary before a government intervention scheme is implemented in order to avoid or minimize disasters like the ones in Scott's (1998).

The need to improve is a common justification and a readily available reason for development and resource projects or programs. In this study, the interveners are considered trustees in the manner defined in Li (2007a: 4); as those who "claim to know how others should live, to know what is best for them, to know what they need." This claim of knowing is also a claim to power and authority. In chapters 5, 6 and 7 we shall see how actors' claims to power and authority over resources are justified through discourses of land security, employment for poor urban dwellers, and food and nutritional security (Mahama, 2015; Ministry of Land and Forestry, 2003a, Ministry of Land and Forestry, 2003b; Tenkouano, 2012).

The notion of governmentality has, at its core, the concept of power in the Foucauldian (2001) view of it as the 'positionality' of the actor at the time of an event or intervention and the practices therein. Government interventions are done by multifaceted institutions who exercise authority and power by reshaping and guiding the conditions of the socio-economic and political life of the people as they are being conducted (Dean, 2010). This is a subtle form of power which is directed from afar; it "operates by educating desires and configuring habits, aspirations, and beliefs" (Li, 2007b: 5). People do what they ought to do and not necessarily aware of the conditions that influence their compliance nor the effects (Colvin et al., 2011). This kind of state power is produced through techniques of registration and identification. The existence of a new public administration as a result of technology has increased the pace and frequency of interventions and subsequent techniques of evaluation and budgeting. When these processes are added to the repertoire of governance from a distance, we experience what Strathern (2000) refers to as neoliberal rationalities of government (Rose, 1999; Rose and Novas, 2007). The notion of governmentality gives then the avenue by which one understands how this subtle power works during government interventions.

Three concepts are used to analyse government power (Foucault, 1991). Inda (2005) identifies them as political rationality, technologies or techniques of government, and the formation of subjects. Government technologies and political rationality often go hand-in-hand. Lemke (2000) explains the relationship between the two concepts using the French words gouverner, which refers to one who governs, and mentalité, the mode of thought or way of thinking. He insists that it is impossible to study the techniques of power without understanding 
the rationalities that underpin them. Government or political rationality is defined as intellectual machineries that turn social reality into manageable and amenable situations for government interventions through the process of problematization. Problematisation refers to the process of problem identification and the resultant proposal of solution to such problem; even projects that failed call for rectification of some of these problems (Dean, 2010; Li, 2007a; Rose \& Miller, 2010, 2010, 2010). Problematization is a key practice of governments and Bryant (1998) considers it a highly political act that may or may not be grounded in scientific fact. Technologies of government further refer to a translation of political rationalities into concrete and specific intervention activities like drip irrigation projects and solar plant programs (Dean, 2010; Rose \& Miller, 2010, 2010). Li (2007a) refers to the process of translating government technologies into concrete projects as rendering an activity technical.

To contextualise this study within the government practices discussed above, the Land Administration Program is an example of how a government could lay claim to certain knowledge about a problem that must be solved. In this example, it is knowledge about the environment and about the problems of landlessness. When a government identifies a problem related to a piece of land for instance, the next step is for it to exercise power over the population regarding their relationships to that piece of land. This knowledge or technology usually has a political motivation which is, to govern people's behavior in accordance to the interest of the state. The projects presuppose then that social reality is programmable and subject to processes that can be acted upon and improved by authorities. The exercise, therefore, of state government power over land in the Ghanaian context can also be seen as a check on the authorities of the chiefs and the resultant transfer of power from the chieftaincy institution to the state government. This is in part why government technologies are sometimes referred to as technologies of power (Lemke, 2000; Merlingen, 2006).

The Actor Network Theory (ANT) was first proposed by, among others, Latour and Callon. The theory explains how ideas become lasting or 'durable' among groups of people through the actions of human and non-human actors in constellations or 'networks.' Latour and Callon's model of power resembles that of Foucault by virtue of the slippery nature of power; that is, it cannot be held or possessed. Power is not produced through the successful creation of a network, but it comes into being as an effect of the creation of the composition of the network (Merlingen, 2006; Rose and Miller, 2010). It is also through such networks that power spreads in time and space, provided the actors in the network do not break away. For durability of the networks, shared interest are realised through negotiations, persuasions, and bargains. This study investigates how government interventions and practices were (and still are) used to enroll different actors into networks by translating their interest and goals into that of the governing body (Rose and Miller, 2010). It also examines how claims to resource access 
are translated and transformed into social, concretised facts in order to lay claim to certain resources.

A powerful actor, agent or institution is one that in a particular circumstance and given moment is able to successfully enroll other actors through the use of artifacts and technology in pursuit of its goals. This means that powers are:

Stabilized in lasting networks only to the extent that the mechanisms of enrolment are materialized in various more or less persistent forms - machines, architecture, inscriptions, school curricula, books, obligations, techniques for documenting and calculating and so forth (Rose and Miller, 2010: 281).

Shifts in power always result in the creation of new subjects or in the co- construction of governance. Generally, there has been less focus on the Foucauldian concept of subject formation. Foucault (1982: 781) defines a subject as being "subject to someone else by control and dependence; and tied to his own identity by a conscience or self-knowledge." This suggests a form of power which subjugates and makes 'subject of' and 'subject to political forces, that are subject to change over time. Foucault identifies three types of struggles that explain the concept of subject formation. These are, the struggle for domination (which can be religious), social forms of exploitation that separate one from what he produces, and voluntary subjugation (Foucault, 1982). For example, opposition to the power of men over women or of parents over children shows common themes of antagonism, as we all struggle against the submission of people's subjectivity.

Agrawal (2005) and Li (2007a, 2007b) have argued that the effects of governmental interventions should be related to and included in governmentality studies. The literature on effects of governmental interventions on subject's formation is multifaceted: subjects at times have been transformed to envisioned subjects, that is, subjects who accept to be transformed. In other cases, subjects contest governmental projects that target them, for example Agrawal's (2005) study on environmental subjects in Komaon, India and Li's (2007) study in Sulawesi, Indonesia. According to Bose et al. (2012) subjects may resist identity change only to internalize it later on. Studies like this raise important ideas as to the 'docility of the governed,' as explained in Merlingen (2006), and the incapacity of government practices to sometimes produce the expected change they seek (Inda, 2005).

\subsection{Processes of access and property}

This section examines how actors gain legitimacy and authority through their interactions with other actors or relations with politico-legal institutions. It explains how property right is just one 
strand of power used by actors, agents, and institutions to gain and maintain access to resources for vegetable gardening. Furthermore, it also uses the resource access theory to explain and analyze how resources are accessed and channeled for vegetable cultivation by farmers and how these interactions or relations directly or indirectly influence adoption of new technology.

\subsubsection{Property rights and claims}

According to Grey (1980), the common conception of property is physical things that are owned by people. Ownership in this context is viewed as having exclusive control over a thing and the ability to use it as one pleases. Grey contrasts this common ideology of property with the theory of property rights advocated by economists. Ownership from the economists' point of view is a bundle(s) of rights (Grey, 1980). Grey argues that the question of what property is differs in this modern capitalist system from the latter traditional systems. For example, are property rights still linked to things in the context of intangible properties like stock, a piece of insurance paper, franchise, patents, copyrights? If property rights are more than just rights of 'ownership' and rights to 'things,' then what are they and what is property in particular?

Benda-Beckmann, Benda-Beckmann, and Wiber (2006) are of the opinion that property is a multifaceted concept that cannot be captured in a one-dimensional political, economic, or legal model. They state that a discussion of property entangles one in a deeply conceptual historical discussion of property regimes. Property can be many things; it is a constituting factor in the identity of an individual or a group of people. Property can be wealth and wealth is a major source of political power over people and labour. This means that property is a vital element of political control over an organisations or people in the society. BendaBeckman, writing from a legal anthropological perspective, is concerned with how property operates in the real world as opposed to how it functions in the neo-utilitarian view of how it should be designed and approached (Benda-Beckmann, Benda-Beckmann, \& Wiber, 2006; Rose, 1994). Property, stated by Benda-Beckmann et al. (2006), centers on relationships amongst social actors with regards to valuable objects. The social actors may be individuals or groups. These actors are linked to property in the form of 'enforceable claim' which to Macpherson (1978) means to use or benefit from something that is supported by society "through law, custom or convention" (Ribot and Peluso, 2003: 155).

Given the extensive literature on property, this discussion is limited to aspects of the property theory that find resonance with the empirical findings of this thesis. This study defines property as a 'legalised claim' - a claim that is sanctioned by the state or some other form of politico-legal authority (Sikor and Lund, 2009). Macpherson (1978) and Neale (1998) define property as a "moral claim to rights arising from the mixing of labor with land" and "property . .. a right in the sense of an enforceable claim" to use or benefit from something (Ribot and 
Peluso, 2003: 155-56). Thus, chosen for this study is a strand of property that is defined by claims to physical things as opposed to rights to ill-defined and vague objects in the modern economic sense.

The term 'bundle of rights' has dominated the property scholarship since it was first used by Maine (1861) (Benda-Beckmann et al., 2006; Meinzen-Dick and Pradhan, 2002; Ostrom and Schlager, 1996; Schlager and Ostrom, 1992). The term right is appropriate as a synchronic snapshot of the analysis of property as a bundle of rights. Schlager and Ostrom (1992) have distinguished five property rights that groups or individuals can hold with regard to common pool resources such as grazing land, agricultural land, and fisheries. These rights are the right of access, the right of withdrawal, the right of management, the right of exclusion, and the right of alienation. The term 'rights' has a certain fixedness and degree of permanency which does not interact well with calls to regard property as ever changing, negotiable, and relational (Benda-Beckmann et al., 2006; Berry, 1993; Hann, 1998; Juul and Lund, 2002; Leegwater, 2011; Meinzen-Dick and Pradhan, 2002).

The term 'claim' better captures the negotiable, dynamic, and temporary nature of property in Tamale. By focusing on claims and the practices involved in claiming, this study shows that property is a process and not a finished product. In other words, socio-economic change and transformation are characteristic of a property (Berry, 1993; Ingold, 1986). The term 'claims' also focuses our attention on claimant and counterclaimant as well as the authority that legalises or validates these claim(s). We shall see in chapter 6 and 7 that claiming land as individual property and the process of legitimising claims generally are not simple procedures.

\subsubsection{Access}

As discussed above, access involves more than having a right to a particular thing. Access is defined by Ribot and Peluso (2003: 153) as "the ability to derive benefit from things." Things will include material objects, persons, institutions, and symbols through which access to and control over resources is possible and benefits here stands for the material use of these resources. By focusing on ability rather than rights, attention is shifted to a broader range of social relationships that can enable or restrict benefits from resources without "focusing on property relations alone" (Ribot and Peluso, 2003: 154). Ribot and Peluso offer a practiceoriented approach that allows for empirical investigations into the processes of access with a "...focus on the issues of who does (and who does not) get to use what, in what ways, and when (that is, in what circumstances)" (Ibid: 154).

This study explores the different 'bundles of power,' a term borrowed from Ghani (1995), used by farmers to gain access and control over resources necessary for dry season vegetable farming. These bundles of power can be obtained through material objects, persons 
in authority, institutions, and symbols which farmers can draw on at different historical moments and on different scales. Taking a strand from these bundles of power simply means using one of the options available to an actor. Access in this context is viewed as a bundle or a web of powers. This bundle is placed within the politico-economic framework that makes clear the circumstances under which actors are permitted or denied control and use of resources (Ribot and Peluso, 2003).

Maintaining access involves investing in relationships with resource owners or overseers such as other individuals, groups or institutions and expending resources to sustain it (Berry, 1993). Controlling access, however, "is the ability to mediate other's access" (Ribot and Peluso, 2003: 158). It is worth noting that one actor or institution could hold a strand from a bundle of powers that permits them to control and maintain access to a resource alone or share the access routes with other competing or cooperating actors. In other words, access alone does not translate into absolute or exclusive control. This has led to the inability to fit resource access and control into a traditional Marxist frame.

The term 'ability' is key in Ribot and Peluso's definition of access. It makes reference to relations of power that could constrain or enable a person to benefit from a resource (Ribot and Peluso, 2003). The concept of control is crucial to the resource access literature. An actor is in control if he or she holds the power to moderate access to others. This makes the relationship that one has with another who is in control crucial to the latter's ability to successfully keep a resource access route open (Ribot, 1998; Ribot and Peluso, 2003). Ribot and Peluso (2003: 154) focus on "the range of powers...that affect people's ability to benefit from resources". The concept of access is a starting point and a common denominator in the analysis of resource transformations on the one hand, and resource conflicts on the other.

\subsubsection{Grey zones between property and access}

Resource conflicts and landlessness in Tamale can be partially attributed to the selling or the allocation of communal lands to real estate developers by local chiefs. As stated in chapter 1 , these lands are often sold without the knowledge of the farmers who cultivate them. This has resulted in a struggle by farmers to hold on to mostly undeveloped public lands. As discussed later in chapter 7, most of these lands, especially those in Gumbihini, are labeled green belts by state land agencies because they are prone to floods. In these particular zones, gaining access to land after the flood requires appropriation by farmers and chiefs. The theory of property is used later on to theorize the type of control that is pertinent in the land management of the green belt.

Sikor and Lund (2009) view property as 'legitimised claim' in the sense that it implies a recognition by the state or some other form of politico-legal authority. Along that line, Meinzen-Dick and Pradhan (2002) also define property as a claim to use or control resources by 
an individual or a group of individuals that is recognised as legitimate by a larger collectivity and protected by law. The difference between property and access is that while property presupposes a legally and or socially recognised claim, access to a property is not only obtained through legally and or socially sanctioned means. An individual could access and benefit from a resource through illegal means such as theft or violence (Ribot and Peluso, 2003). Property or legal access' in Ribot and Peluso's terms is a subset of access. This translates into the idea that one "may derive benefits from a resource without holding property rights to them" (Sikor and Lund, 2009: 4). Gumbihini farmers in Tamale consider the green belts they farm on literally as their 'property.' This is because their access to these sites is sanctioned by a politico-legal authority, that is, the state and sometimes NGO's. It is for this reason that farmers are shifting from the traditional land governance system to the modern land governance system which justifies their access to the green belts, as will be later explained in chapter 6 and 7 .

The overlap between access and property as explained above is what is referred to as the 'gray zone' (Ribot, 1998; Ribot and Peluso, 2003; Sikor and Lund, 2009). Many formerly colonised countries including Ghana are characterised by a legal pluralism as a result of overlaps in administrative activities between state and the chieftaincy institution. An example of the 'grey zone' is seen when people attempt to secure rights to resources by having their claims recognised by a politico-legal institution (Merry, 1988). Recognition establishes an individual's right to a property, but it also empowers the authorizer by re-affirming its right to recognize (Sikor and Lund, 2009). The effort of farmers to gain access to and control of the green belts in Gumbihini is central to the discussions in chapters 6 and 7 .

\subsubsection{Legitimacy and its associated practices}

According to Sikor and Lund (2009), an act of legitimation by a politico-legal authority is a distinguishing feature between access and property. The practice(s) of legitimization is/are critical in this study since actors and institutions are interested in having their claims to resources legitimised. As Lund (2006) states, the exercise of authority is intimately linked to the legitimacy of that particular institution. This is because to exercise power, one must have a specific or a historical claim to legitimacy (Sikor and Lund, 2009).

Lentz (1998) and Moore (1998) suggest that legitimacy is conceptualised not only as a fixed element against which conduct can be measured but also as a dynamic concept. This is done by investigating the processes of legitimate actions that are attempted by various actors and institutions (Fortmann, 1995; Rocheleau and Ross, 1995). What is considered legitimate varies in time and space between and within cultures and is continually re-enacted and re-established through conflicts and negotiations (Ribot and Peluso, 2003; Sikor and Lund, 2009). An important process to legitimization is social conceptualisation, which is how con- 
cepts and truth are established (Agrawal, 2005; Ferguson and Gupta, 2002; Li, 2007a). Different occasions give rise to opportunities to make claims legitimate and to engage in several repertoires (Lentz, 1998) as people and institutions interpret concepts in an attempt to justify their differing political interests and projects (Lentz, 1998). This process creates an "ongoing redefinition of the very concept of property" which might be seen as fixed (Sikor and Lund, 2009: 7).

Sikor and Lund (2009: 7) argue that what is considered a legitimate property "is historically contingent" on "contemporary political constellations of institutions that can recognize claims as valid." What is perceived as legal or illegal can change over time. Thus,

\begin{abstract}
Government policies, statements and practices can effectively outlaw certain legal practices and nullify established rights. Government may thus effectively turn private property into public land, and the inventive opportunism of farmers may secure them private rights to public infrastructure, contrary to the legislation in place (ibid: 7 ).
\end{abstract}

An example is illustrated by the State Land Act 1962 (Act 125) ${ }^{14}$. This Act permits the state to take any land it chooses for public use which led it to seize many lands for state use without compensating those who were affected. Traditional laws also allow farmers to appropriate community lands at the discretion of local chiefs. How government statements and policies have nullified established rights is discussed in chapters 6 and 7. It is worth noting that the processes or mechanisms by which claims to properties are legitimised are not the same for all actors. In other words, different actors use different means to have their claims to land and other resources recognised by the relevant authority. (Sikor and Lund, 2009).

Local political actors often question the legitimacy of many private and public properties especially during political transitions. Rights to resources in many African countries often change with changing political leadership. This makes the relatively more stable chieftaincy institution much more reliable and by extension, more trustworthy (Lund, 2002). In this study, I will explain how the waxing and waning power of chieftaincy over natural resources in Ghana from pre-colonial times till now has shaped and reshaped what is considered property rights over resources, in particular land and water. Claimants seek politico-legal institutions to au-

\footnotetext{
${ }^{14}$ State land 1962 (Act 125), State land Amendment 2000 (Act 586) and also Article 20 of the 1992 constitution of Ghana.
} 
thorize their claims and politico-legal institutions also seek claims to be legitimized, a relationship better explained in Benda-Beckmann's (1981) notion of 'forum shopping,' and 'shopping forum':

In the presence of competing forums for resolving disputes, contestants tend to 'shop' for forums for dispute resolution, and forums actively shop for disputes in an effort to consolidate their authority. Such competition can unfold in many different fields, such as citizenship/belonging, personal security, development and property (Sikor and Lund, 2009: 11).

Forum shopping is:

The ability of some actors to select the arena of law, custom, or convention that will favour their objectives-the importance of political-economic and cultural forces beyond the legal sphere becomes more evident in determining who can use law, custom, or convention, when, and for what purposes (Ribot and Peluso, 2003: 157).

Land in northern Ghana has changed many hands from pre-colonial times to present (see chapter 5). Farmers in the region often 'shop' for forums - which means they identify from a pool those institutions which best serve their interests in accessing and maintaining control of farmlands. Farmers also solicit support from various forums within the same institutions to gain access to resources. The idea of forum shopping as explained by Benda-Beckmann (1981) has also been used by Bierschenk and Olivier de Sardan (2003). The latter discuss institutional shopping in which actors discriminate between different institutions depending on which best advance their interest at a particular time. Later in this thesis, the Actor Network Theory will be used to illustrate how different actors shop for forums.

\subsubsection{Appropriation links access to property}

Ribot and Peluso (2003: 160) define access analysis as "a process of identifying and mapping the mechanisms by which access is gained, maintained, and controlled." They also agree with Berry (1993), Lund (1994), and Peluso (1996) that access is conceptualised as a bundle of processes. The processes of appropriation and claim making as key practices adequately bridge the viewpoints. Appropriation can be viewed as the process through which access metamorphoses into property. The concept of appropriation helps to understand practices of claiming land in public spaces in Tamale. 
According to Locke in Olivecrona (1974: 92), appropriation is the act of "making a thing proper to oneself." How people appropriate is key to Locke's idea of the origin of property. According to it, appropriation is the beginning and foundation of the right to property (Olivecrona, 1974). Locke's theory of the right of property and its origin is influenced by the history of agrarian enclosure in England (ibid). From the fifteenth century to the seventeenth century, the rural population in England enclosed the common lands for its use (KingstonMann, 2006). The process of appropriation as found in Tamale parallels the enclosures in England at that time. In the Tamale area, families succeeded in acquiring individual rights to state lands simply by demarcating the land and fencing it (see chapter 6). The echoes Karl Marx's term 'land grabbing' which he used to describe the English enclosures (White et al., 2012).

Ingold (1986: 133) links property, appropriation and the processes of making claims. He describes landed property as "a mode of appropriation by which people exert claims over resources dispersed in space." Ingold insists that every claim is part of a continuous process, stressing the importance of viewing property from a diachronic perspective. He also states that during what is termed here as the appropriative movement, information on territorial demarcations are communicated. He describes this as a kind of territoriality (Ingold, 1986). Communication can be carried out in various ways: if the parties concerned are not in direct contact, then a sign language is used. Signs are 'written' on the landscape in the form of durable boundary markers of diverse kinds from which implicit messages can be read (Ingold, 1986). This communicative aspect of appropriation is taken up in the next subsection on claim-making and also in chapters 6 and 7.

\subsubsection{Practices of land appropriation: grounding and talking claims}

Appropriation, as explained above, is the process of making land one's own through recognition by a politico-legal institution. Claiming land is a process that requires a lot of investment of time, labor, and relationships. The first step towards making a claim needs to be communicated and other actors persuaded that it is valid as individual property (Juul and Lund, 2002).

There are two main processes of acquiring land in northern Ghana. Land appropriation usually starts with "grounding claims" which is a process of gaining land by inscribing and altering its landscape using socially understood symbols. A fence, for instance, is an example of a grounded claim. However ramshackle it may appear, it is a powerful assertion of ownership over an enclosed piece of land. Disagreement over grounded claims can be expressed by destroying the fence (Fortmann, 1995). Destroying a fence is considered a grounded counterclaim. As long as the grounded claim is not challenged or questioned, then it is socially and legally recognised as possessed. When grounded claims are challenged, an alternative 
means of claim-making by the incumbent is necessary to maintain access. Otherwise, the challenger's counterclaim will be recognised.

In conclusion, the appropriation process begins with a claim, followed by a legal and or social recognition of that claim and finally its consolidation. If a grounded claim is challenged, it may be countered by a talking claim. Both processes of appropriation are discursive ways of claiming land and forms of communication intended to persuade people to recognize these property claims. The former is written in the landscape, and the latter is spoken out during land dispute meetings.

\subsubsection{Governmentality and appropriation at land dispute settlement meetings}

Land dispute settlement meetings are occasions when claims are 'talked' by disputing parties and lands are appropriated. Talking claims and appropriations correspond to what BendaBeckmann et al. (2006) call concretised social relationships, which is one of the legal institutional analytical layers of property. In concretised social relationships, property relations are expressed between real people and real objects, an example being the claim that a land belongs to the one who clears it. The legal and institutional analytical layer (categorical property) is identified when property relations between people and objects are socially and legally formalised as if one leaves the village, then he loses access to the land in that village which he previously had.

In practice, these different analytical layers interact in myriad ways and mutually influence how property falls into the separate layers (Benda-Beckmann et al., 2006). Chapters 6 and 7 discuss a case in which a dispute over concretized property practices by different actors result in attempts to formalise claims by some actors which gave rise to new forms of property rights. The analytical frame offered by Benda-Beckmann et al. (2006) provides a useful way to analyze the way property is created, maintained, and sometimes reshaped. This research studies landed property relationships acting at the socially concretised and legal-institutional levels, and land dispute settlement meetings provide the settings in which interactions between the two layers are explored.

When disputants 'talk` claims, they are mostly concerned about their relation to the property or object under dispute. Property in this context comes in the form of a concretized relationship. However, discussions about it is often abstract and in terms of rules and categories which brings it under the legal-institutional analytical layer. Land dispute settlement meetings are therefore settings where different ways or processes of negotiation are explored. State or customary law act as a source of legitimacy for property claims (Ribot and Peluso, 2003). They spell out regulations on use of and access to resources. These regulations can range from basic rules like who has what rights to a resource to more solidified social norms 
and procedures on how rights to resources can change and by who (Benda-Beckmann et al., 2006; Sikor and Lund, 2009).

Rules in this context refer to "generally agreed-upon and enforced prescriptions that require, forbid or permit specific actions for an individual" (Ostrom, 1986; Schlager and Ostrom, 1992: 13-15). This thesis uses a similar view to analyze customary rules (generally unwritten) used to validate claims and solve land disputes at dispute settlement meetings. These customary rules are not static. As Moore (1989) shows with the example of the Chagga law, they are constantly changing and adaptive. In a legally pluralistic society, multiple rights with divergent backings or sources of legitimacy coexist and interact with different institutions and authorities (Meinzen-Dick and Pradhan, 2002). In the face of changing land tenure practices, the state and the chieftaincy institution have not always applied the same rules or rational to land dispute settlement cases. In the process of settling land and other disputes, both institutions are engaged in governing; that is, they are engaged in shaping aspects of human behavior according particular sets of norms as further discussed in chapters 5,6 , and 7 .

\subsection{Conclusion}

This chapter has explored the theoretical concepts of governmentality, enrolment, resource access, and political ecology. These concepts help understand how farmers take advantage of overlaps and ambiguities in existing governance systems in order to be able to gain and maintain access to resources. Governmentality is conceptualised as interventions by state, civil society, and multilateral organisations through the use of technologies to condition people's access to resources at different times and scales. These interventions are engineered internally by different internal and external actors; internally by actors such as the state, traditional institutions, and national civil society groups and externally by actors such as multilateral and international organisations with varying degrees of independence from their national governments.

These interventions have the intended consequence of conditioning subjects 'behavior in subtle ways. When government interventions take place, subjects resist, endorse or sometimes actively partake in the creation of a new governance system or a hybrid governance system. The interventions in this study are evidenced by the different technological packages introduced at farm level by civil society organisations sponsored by international development agencies and also by land administration projects of the state, partnered with multilateral and international development organisations. These interventions, as shown in the later chapters, are critical to structuring control and access to resources as well as shaping agricultural discourses at both the national and international levels.

This chapter has also shown that government interventions are received in varying ways by different actors, resulting in multiple government systems. From the resource access 
theory and the concept of enrolment, when interventions take place, one's ability to benefit from them depends on their social and or political standings in society at a given time. The passage of time often goes with it changes in standings which could impact an individual's ability to access and control farm resources. One's access to and control over a resource(s) over time. How a farmer manages his relationship with powerful to actors in a particular sociopolitical space may also affect his ability access to keep access routes to resources. In a nutshell, an actor's ability to gain and maintain access to resources depends on the following:

1. His position in society or in an institution at a given socio-political moment.

2. The social relationship he has with other actors or institutions.

3. His ability to draw upon different bundles of power at different times.

4. His charisma and general ability to be persuasive

5. The ability to appease and retain different actors within a network which requires great negotiating skills

6. Taking note of socio-political changes and adapting to them.

7. Making use of information, markets, social identity, capital, and labour.

8. Use of illegal mechanisms of access such as theft and deception.

Thus, keeping up with the changing socio-political environment and maintaining cordial social relationships can keep resource access routes open and secure them for use by actors.

The employment of political ecology theory in this chapter also shows how concepts such as 'authority,' 'power' and 'legitimacy' play out in resource access in Tamale and Africa. Power is controlled by the one who has it at a given time, which means that an actor or institution can draw on his/her power to gain access to a resource. Actors or institutions can also gain access to a resource through social relations. In chapter 5 , we shall see how shifts in power relations between the state and chieftaincy institutions have, over time, reconstructed what is now considered as the contemporary land tenure system.

Lastly, this chapter illustrates the processes by which farmers cooperate with each other and with other actors, persuading them to support their agendas and interests. Alliances between different actors when government projects are implemented often results resulted in changes to individual behavior in relation to resource access and control. Different power relations exist in this 'game' of access, in which all actors are participants in resource governance.

The next chapter, I will situate this study in a geographical, socio-political, and demographic landscape. It always explains the methodology used and how the field data was analysed. 


\section{Chapter 3 - Background of Study Area}

\section{Introduction}

The positioning of households in the Northern Region`s urban landscape is largely due to outdated planning laws. This positioning has created opportunities for urban dwellers to pursue their livelihoods in a wider socio-demographic, physical, economic, and policy environment. While individual households may constitute separate units of production, they are not independent actors in their environment. The wider and complex urban environment in which they exist presents both constraints and opportunities in the pursuit of their livelihoods. These opportunities and limitations are constantly changing over time with varying impacts on the livelihood of the people (Geest, 2004). Thus, urban and peri-urban structural characteristics shape the nature of people's livelihoods and the vulnerabilities they face. This chapter discusses some features of the urban and peri-urban environment in which farmers from different households pursue their livelihoods. The goal is to shed light on how the different variables in the environment influence urban and peri-urban agriculture - that is, enabling and constraining farmers' access and control over agricultural resources.

This chapter is structured into two sections. The first section describes the physical features of, and the socio-economic activities of people in, Tamale. This analysis serves as a basis for understanding the effects of urbanisation, population growth, and climate variability on urban agriculture in this study area. This chapter I discusses how urbanisation and a valuable land market has led to an increase in the 'sale' of agricultural lands for residential purposes and the resultant effect of changing land use patterns on farmer's economic activities. This chapter also explains the contribution of a number of socio-cultural factors to the current agrarian system of the region under study. Furthermore, it explains how the outdated urban and peri-urban planning laws in Ghana have contributed to the state of urban agriculture in the Tamale Metropolis.

The second section of this chapter provides an overview of the author's fieldwork, followed by a detailed discussion of my sampling techniques, data collection methods, and the reliability of the study and finally, a summary and a conclusion to the chapter.

\subsection{Background of study area}

The study area under discussion is Ghana's Northern Region. Discussion on Tamale became a commercial and educational hub in this region will be provided. Climatic and physical characteristics will also be explained, as they are essential elements in any agricultural production system. A brief summary of the socio-economic activities will be discussed in relation to the 
present land tenure system and the effects of urbanisation and population growth on resources availability, access, and control.

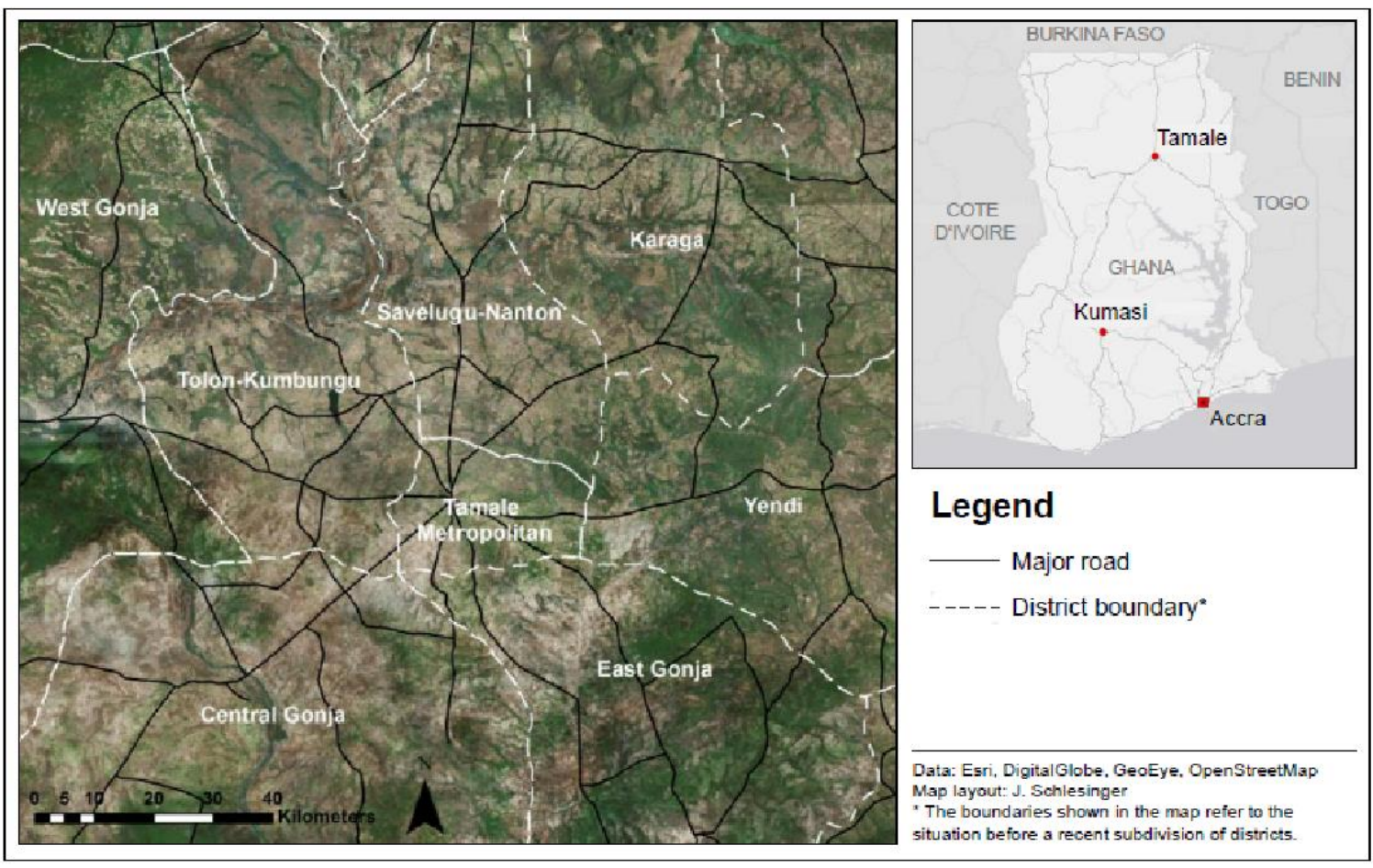

Figure 3.1: Map of Tamale, Northern Region of Ghana

Source: Nchanji et al. (2017)

\subsubsection{Location and Origin of Tamale}

Tamale is the third largest city in Ghana, located between latitudes $9^{0} 16^{\prime} \mathrm{N}$ and $9^{0} 34^{\prime} \mathrm{N}$ and longitudes $0^{\circ} 34^{\prime} \mathrm{W}$ and $0^{0} 57^{\prime} \mathrm{W}$ (Figure 3.1). It is bordered to the North by the Savelugu-Nanton Municipality, to the North West by Kumbungu District, to the East by the Mion District, to the South East by the East and Central Gonja, and to the West by the Tolon District. It covers a land surface area of $922 \mathrm{~km}^{2}$ and it is situated in the center of the Northern Region. Tamale is also considered the economic capital of Northern Ghana.

Between 1988 and 1914, present day Northern Ghana was partitioned between the Germans and the British colonizers. This partition split the Dagomba kingdom into two, with Eastern Dagomba falling into the hands of the Germans and Western Dagomba the British. During this time, the British section was governed from Tamale where both the District Commissioner in Western Dagomba (sometimes called Tamale District) and the Provincial Commissioner of the Southern Province had their headquarters. In 1907 when civil administration was introduced, Tamale became an administrative capital of the British colonial government with 1435 people (Staniland, 1975). The relocation of the administrative capital from Gambaga to Tamale during the British rule was due largely to its centralised location, constant water 
supply, and vibrant market. (MacGaffey, 2006). The administrative move led to an inflow of capital to Tamale arising from the construction jobs that accompanied the move.

Tamale began to experience rapid economic growth from 1909-1913 as more permanent structures were built and a formidable cotton industry came into being with the installation of a cotton gin and press (Dickson, 1968; Staniland, 1975). However, by 1914 economic growth had begun to stagnate due to the British colonial administration`s labour policy. This policy favoured the recruitment of labour from northern Ghana to the mines of the southern region, a policy that drained the workforce of the north and undermined its ability to develop its cotton industry among others (Staniland, 1975). Another reason for the collapse of the cotton industry was due to the concentration of free manual labour on road networks during farming periods and the low prices offered for cotton by European merchants (ibid). After independence, Ghanaian towns and cities like Tamale experienced a bump in population (Fuseini and Kemp, 2015). In the period 1960 to 1970, Tamale`s annual population growth rate was the highest among all the metropolitan districts in Ghana -7.2\% for Tamale compared to $5 \%$ for Accra and $4.4 \%$ for Kumasi (Ghana Statistical Service, 2005). The population of Tamale, as shown in 3.2, increased even in the 1980s, when economic conditions were tough and the population of most urban areas declined

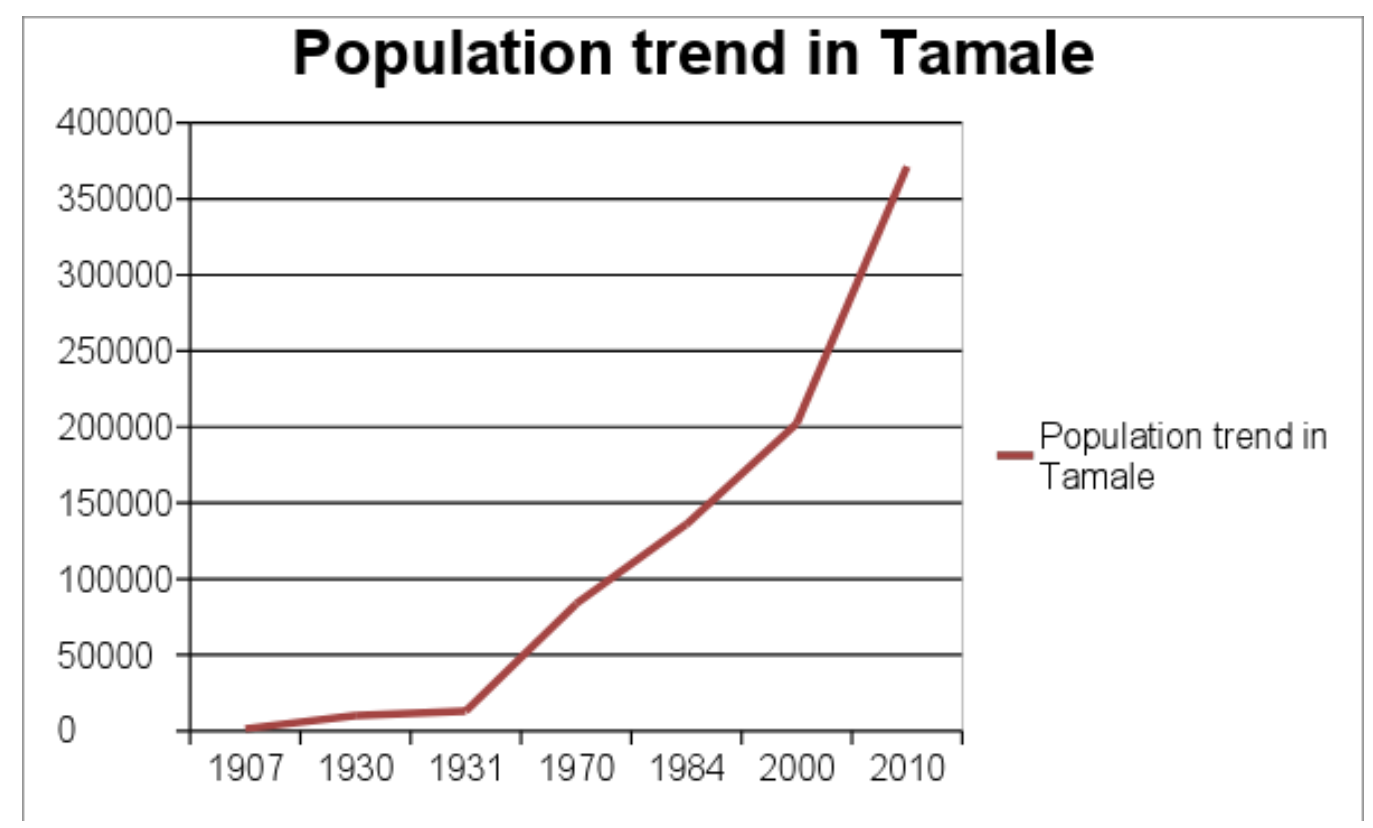

Figure 3.2: Population trend of Tamale between 1907 and 2010

Source: Ghana Statistical Service (2005), Ghana Statistical Service (2013), Gyasi et al. (2014), MacGaffey (2006) and Staniland (1975) 
Tamale's higher population growth is attributed to the vibrant rice industry promoted there at the time as part of the 'make Ghana self-sufficient` campaign shortly after independence (Gyasi et al., 2014). As shown in figure 3.2, the current population of Tamale is more than 371,000 and it is one of the fastest growing cities in Africa according to Ziem and Gyebi (2011). Tamale's location near smaller districts with vibrant agrarian economies and countries including Burkina Faso, Niger, and Mali makes it the trade magnet of the north and the link between local producers and foreign buyers. The following section describes the physical characteristics of Tamale.

\subsubsection{Physical Characteristics}

The most outstanding physical features of Tamale include its relief, climate, and vegetation. These features are relevant to understanding how nature has shaped the agricultural system of Tamale and. They also help one to understand where resources are situated and how they can be accessed and controlled. The physical characteristics of Tamale, points to possible access points for infrastructural services which are tied to the socio-political environment.

\subsubsection{Relief and drainage}

The Tamale Metropolitan Municipality has what Laryea-Adjei (2007) describes as a rolling topography. It is about 180 meters above sea level as indicated in Table 3.1 below. Tamale is poorly endowed with water bodies - notably few streams like the Pasam, Dirm-Nyogni, and Kwaha. There are about 91 dugouts according to Laryea-Adjei (2007) which provide water for domestic, agricultural, and industrial purposes. Reservoirs and dugouts have traditionally provided water for free range livestock rearing, drinking, cooking, and crop irrigation. Urbanisation and population growth has increased the demand for water for household and agricultural use. This need has partly been solved by the provision of additional dugouts and dams with assistance from international non-governmental organisations like the Deutsche Gesellschaft für Technische Zusammenarbeit GmbH (GTZ) - or what is now known as the Deutsche Gesellschaft für Internationale Zusammenarbeit (GIZ) (Eguavoen, 2008).

Reservoirs and dugouts are the main sources of water for urban and peri-urban vegetable production (see Figure 3.3) as stated by Gyasi et al. (2014), even though the quality of these water sources are not considered safe for drinking or irrigating vegetables eaten raw (Abdul-Ghaniyu et al., 2005; Cobbina et al., 2010). Despite their importance, poor management and housing encroachment in the different communities have often threatened their existence. For example, the dugout in Kpenni collapsed due to poor management and presently the reservoir in Fooshegu is poorly being managed. Officials from the Ghana Irrigation Authority (GIDA) visited this site with this author on a tour to see what can be done to revamp it. The 
Reservoir in Buipela is drying out and over the years the chief has allocated almost all surrounding agricultural land (around the riparian buffer meant to protect the reservoir) to real estate developers. A riparian buffer is generally a vegetated area around a stream or reservoir intended to protect it from the impact of adjacent land use. It also has environmental benefits such as increasing water quality and reducing water pollution. The construction of houses for any purpose along a reservoir will lead to the weakening of its walls and a possible future breakdown (Acheampong and Sekyi-Annan, 2014).
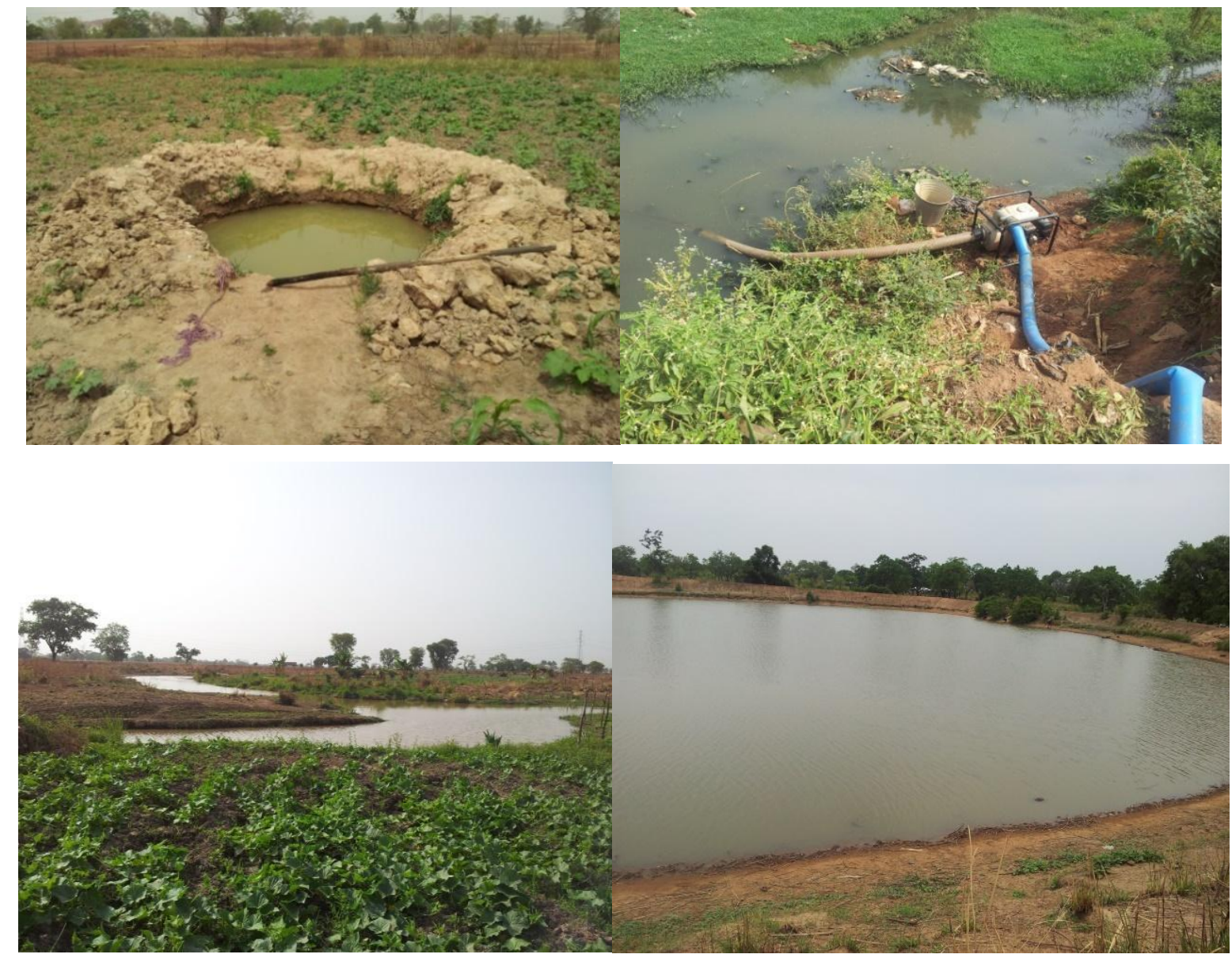

Figure 3.3: Different water sources used for vegetable gardening

Source: Author's fieldwork 2014/15

The topography of Tamale makes the region susceptible to floods especially in the Eastern part of the Municipality. Mr. Akwettey Samson, Head of Waste Management Unit stated in an interview with the author that storm drain and retention pond will be built around the Gumani area to reduce floods during the rainy season. This exercise will be carried out under the Ghana Urban Management Pilot Project (GUMPP) in Tamale. The GUMPP projects are expected to take place in several Ghanaian bankrolled by the Ministry of Finance and Economic Planning (MOFEP) thanks to a 40-million-euro loan and a 500,000 euro grant from 
the Agence Française de Développement (AFD). The following section describes the climate and vegetation that shape Tamale's agriculture.

\subsubsection{Climate and vegetation}

As shown in Table 3.1, Tamale lies in the semi-arid guinea savannah ecological zone in West Africa with a relatively dry climate. In recent times, farmers in the area have been worried by the later start of the raining season in July as opposed to May/June previously (Gyasi et al., 2014). A unimodal rainfall pattern is experienced in this area due to the moist South Western winds as opposed to a bimodal pattern in the South (Nkrumah et al., 2014). This has given rise to a single agriculture production season in Northern Ghana since most agricultural production is rain-fed. Given that farming is a major livelihood and irrigation infrastructure is limited, underemployment in the dry season is high among the local populace and it is one of the reasons why dry season vegetable cultivation is promoted by civil society organisations. Furthermore, rain-fed agriculture is adversely impacted by climate change and variability. The harmattan period is getting drier and hazy, influenced by the North Easterly winds which blow across the sub-region from the Sahara Desert around October and February each year (Cobbina et al., 2013). The mean annual temperatures are also rising according to Gyasi et al. (2014) and Asante and Amuakwa-Mensah (2015).

Table 3.1: Climatic data of Tamale

\begin{tabular}{|c|c|c|}
\hline Parameters & Measurements & Source \\
\hline Elevation & $180 \mathrm{~m}$ & Ghana Statistical Service (2014) \\
\hline Ecological zone & $\begin{array}{l}\text { Semi-arid Guinea Sa- } \\
\text { vannah }\end{array}$ & Gyasi et al. (2014) \\
\hline Rainy season & May to October & Gyasi et al. (2014) \\
\hline Dry season & November to March & Gyasi et al. (2014) \\
\hline Rainfall pattern & Unimodal & Nkrumah et al. (2014) \\
\hline
\end{tabular}

The vegetation in this area is characterised by guinea savannah woodlands, tall grasses, and drought-resistant trees like Azadirachta indica, Vitellaria paradoxa, Parkia biglobosa and Ceiba pentandra, with a ground cover of perennial grasses such as Andropogon gayanus. The four trees listed above form part of resources that women use in meeting their traditional provisioning responsibilities as explained in Nchanji and Bellwood-Howad (2016a). Wood, especially Azadirachta indica, is used for charcoal production. Charcoal production is an important source of livelihood for women in the region, enabling them to provide for basic 
household needs. Especially for the women who have no access to farmlands, charcoal production is one of the few economic activities to which they could turn (Nchanji and BellwoodHoward, 2016a).

Shea nut gathering and processing (into butter) is another major source of livelihood and has been since colonial times (Sutton, 1989). Rising demands from oversea has led to the emergence of many processing mills in Tamale with the financial aid of non-governmental organisations like Urbanet (Naatogmah, 2015). Shea butter is used for a lot of things including cooking, fruit preservation, and cosmetics. Apart from the sheanut tree the seed of the Parkia biglobosa is an important spice used by women in preparing soup for their families (Nchanji and Bellwood-Howard, 2016a). The Parkia biglobosa in public spaces belongs to the sub-chief by virtue of his traditional status, it is a symbol of power and authority in the Dagbon chieftaincy institution. The next section examines the changing socio-economic activities in Tamale.

\subsection{Socio-economic activities}

Here, the economy of Tamale is examined alongside its different social and demographic characteristics. The Relevance of the land tenure system to agricultural production, especially dry season vegetable cultivation in the study area, is also explained.

\subsubsection{Demographic characteristics}

As stated earlier, the Tamale metropolitan area is one of the fastest growing areas in Ghana. The present population of Tamale exceeds 371,000 . $73.8 \%$ of the population is found in the city and only $26.2 \%$ is found in the rural areas of the district (Ghana Statistical Service, 2013: 24-26). A possible reason for this is that as the administrative and economic hub of northern Ghana, job and educational opportunities are more readily available there than in the rural areas or in other districts (Ghana Statistical Service, 2013). The present population also represents a $26.4 \%$ since the 2000 census when the population of Tamale was about 290,000 (Ghana Statistical Service, 2005, Ghana Statistical Service, 2013).

The population of Tamale is a very young population, with $36.8 \%$ under the age of 15 and $58.8 \%$ in the reproductive age. This increases the need for more social services like schools, health care, and infrastructural facilities from the government. In terms of agriculture, the population demographics likely explain the large number of young people engaged in dry season vegetable farming as observed by this author at a number of sites. More telling is the fact that $97.2 \%$ of cabbage farmers are in their reproductive age (Nchanji et al., 2018b). According to Watson (2009), fast-growing towns like Tamale with its outdated urban planning regulations lack the capacity to manage crisis related to infrastructure, the environment, and agriculture. Hence, climate change and food insecurity are major challenges affecting people in the Tamale region Fuseini and Kemp (2015). 
In terms of household structure, most of them are headed by men under a patrilineal system. Because family members live next to each other -usually a husband and his wives, their children and their children's spouses and offspring - household sizes are generally big and come in the form of compounds composed or surrounded of several huts. The following section examines the people of Tamale according to their economic occupations.

\subsubsection{Economic activities}

In the 1960's, $82 \%$ of men in Tamale were involved in fishing, hunting, and farming while $0.2 \%$ and $1.1 \%$ were involved in administrative and technical related activities respectively (Staniland, 1975). In the early $20^{\text {th }}$ century the number of people mainly engaged in agriculture reduced despite the introduction of large demonstration fields and the provision of inputs and technological packages. The organizations and research institutions involved with the introduction of the technological packages include the United States Agency for International Development (USAID), Alliance for a Green Revolution in Africa (AGRA), International Institute of Tropical Agriculture (IITA), and the International Maize and Wheat Improvement Center (CIMMYT) (Gyasi et al., 2014).

The internationally engineered agricultural and technological innovations were nothing new since similar programs were introduced as early as during the colonial era. These projects have have not helped much because of limited synergy between the different institutions who introduce varied agricultural projects without consulting or learning from the failures of past projects. Other reasons have been the overlapping and often competing attitude of aid agencies against one another even when they have the same goals (Owusu Baah, 1995). A third of the population is now involved in service delivery, 17.6 in skilled agriculture and fisheries, and 21.55 I craft or related activities (Ghana Statistical Service, 2013). It is important to note that although more people are mainly engaged in the service industry, more than $90 \%$ of the popukation takes part in one agricultural activity or another.

The shift towards informal economic activities has roots in the colonial construct and the Structural Adjustment Programs (SAP) introduced by the World Bank and the International Monetary Fund (IMF). Colonialism left the North as the most underdeveloped part of Ghana with agricultural projects that did not take into consideration the socio-cultural environment of the people according to Blench and Dendo (2007) and Sutton (1989). The structural adjustment led to the removal of government subsidies on agricultural inputs like fertiliser and social services. This caused serious economic hardships and pushed more than $60 \%$ of the population into the informal sector. Secondly, the structural adjustment went a long way to reducing the purchasing power of the urban poor (Barwa, 1995). The structural adjustment also encouraged key infrastructural developments like the electrification of Northern Ghana through the implementation of the national electricity grid networks and road reconstructions (Bawumia, 
1998). The following section outlines the different social services in Tamale and how they affect its agricultural industry.

\subsubsection{Social activities}

Tamale is a quite homogenous city mostly populated by the Dagombas who belong to the Gur speaking Mole-Dagomba ethnic group of people. The Guan and Akan closely follow with $2.9 \%$ and $2.8 \%$ respectively (Ghana Statistical Service, 2013). Two third of the population is Muslim and the remaining third is either Christian or Traditionalist. According to Imam (2015b), due to the similar practices between Islamic and traditional practitioners, the latter has become dominant although some people adhere to a mixed practice. Christianity entered the Dagbon kingdom mostly through missionary's interactions with the indigenes on an agricultural basis as explained in chapter 4.

Tamale is the most literate district in the Northern Region with $60.1 \%$ of its population aged 11 years or older able to read and write. $48.4 \%$ of these people are found in the urban area (Ghana Statistical Service, 2013). The metropolis literacy rate is lower than those of Accra and Kumasi which are $90 \%$ and $83 \%$ respectively. The Northern Region as a whole has the lowest literacy rate in the country at 37.2\% (Ghana Statistical Service, 2013). Literacy in this context is defined as the ability to read and write. This low literacy rate has socio-economic and political implications for the development of the region since formal education is a major means of skills acquisition which is a prerequisite to most jobs and overall survival in many societies (Ghana Statistical Service, 2013).

According to Afari-Sefa et al. (2015), the International Monetary Fund (2015), and Nchanji et al. (2018a) farmers with more years of education are better at dealing with health and environmental risks in urban and peri-urban agriculture. The Tamale metropolis is rapidly urbanising and white-collar jobs are proliferating, but still a significant proportion of the workforce is in the informal sector. The Tamale metropolis also has the highest percentage of an economically active population at $63.3 \%$ due to the youthfulness of its population and centralised location (Ghana Statistical Service, 2013).

One-third of the metropolis aged 12 years or older owns a mobile phone. According to the Ghana Statistical Service (2013), increased access to cell phones has led to an increase in technology-related education. Internet technology is utilised by more than two-thirds of the people. It is used by farmers to communicate with each other and with merchants. Tamale is not only the administrative and economic center of the north but it is also the Northern Region`s educational hub. It has the highest school attendance rate among 6 year olds or older. However, the fertility rate in the Northern Region as a whole is higher than in other regions as under five years old mortality rate has reduced from 199 to 116 between the 2000 and 2010 census years (Ghana Statistical Service, 2013). 
In the Tamale metropolis, more than $80 \%$ of its vegetables are produced by its informally engaged urban and peri-urban growers (Gyasi et al., 2014). The informal means of production has brought to the fore issues regarding health, water, and nutrition. Three-quarters of the population has no access to pipe-borne drinking water (Ghana Statistical Service, 2013). The scarcity of water in Tamale has led to competition for water resources by different water users and has significantly impeded dry season vegetable farming. How farmers address this threat is discussed in chapters 6 and 7.

The existence of good roads for food transportation has significantly reduced vegetable spoils. This, combined with a ready market for vegetables, have made dry season vegetable farm a niche activity as stated by Drechsel et al. (2006). In the next section, we shall look at the impacts of the land tenure system on the agriculture industry in the context of rapid urbanization and population growth.

\subsubsection{Land tenure}

As mentioned in chapter 1, there exist two land tenure systems in Ghana. These are, the statutory land tenure system and the customary land tenure system (Kasanga and Kotey, 2001; Quan et al., 2008; Ubink and Quan, 2008). Statutory land tenure covers public and vested lands. Public and vested lands are under the control of the government. Public lands are customary lands acquired by the state under eminent domain, a right which allows the state to acquire private property for public use. This is also referred to as compulsory acquisition or purchase. There also exist what is known as vested lands which are community lands vested in the president on behalf of a stool or skin (Kasanga and Kotey, 2001). Under the customary land tenure system, land is vested in the chief who is a trustee of the clan, community or family. The trustee is expected to control and administer the land for the benefit of the community or trustors (Kasanga and Kotey, 2001).

Customary lands are referred to as skin lands in the North while in the South they are known as stool lands. Skin and stool lands are vested in the chieftaincy institution, where the chief is the custodian of land for the people with a social obligation (Yaro, 2010). The chiefs social obligation is to ensure that land under their control benefits all of their subjects or the members of their society (Kasanga and Kotey, 2001). As stated in chapter 1, about $80 \%$ of the land is customarily owned while the remaining $20 \%$ is under the control of the state (Ubink and Quan, 2008). Chiefs have allodial rights over land, which means that they have the ultimate right over land and are expected to administer them for the development of their communities. Lands under the control of the chiefs are not meant to be entirely alienated because they are also the property of the unborn (Nchanji and Bellwood-Howard, 2016a).

In Tamale, the land is mostly owned by chiefs, individuals, clans and families. Few families own land in Tamale compared to the other regions like the Upper West, where most 
lands are family owned (Kuusaana et al., 2013). In Tamale, three-quarters of the land is under the control of the chiefs and the remainder is under the control of the state (Yaro, 2010). The hierarchical position of a chief determines the quantity of land under his control or his influence over land matters. The king of Dagbon, known as the Ya na, is the paramount chief and below him are the district chiefs, local chiefs, village chiefs, sub-chiefs, and the subjects. The king has allodial rights over all lands in the kingdom, but he designates district chiefs to control them. These district chiefs have under them local chiefs who control lands at the local level. The local chiefs also have village chiefs and village chiefs have sub-chiefs under them. Customarily, the dawadawa tree (Parkia biglobosa) is under the control of the sub-chief, and its seed cannot be harvested without his permission.

Traditionally, the existing land arrangement allows natives to acquire land for farming by giving the immediate chief in the area where the land is situated a token - usually cola/ kola nuts. Presently, an additional monetary package has to accompany the kola gift (Yaro, 2010). The land chosen has to be vacant or not occupied by someone. The land has to be continually farmed to maintain use rights as non-use after a period of time is a sign of lack of interest. Non-locals can also have access to land for farming by offering a token to the chief in the form of some kola nuts. However, this right is non-transferable unlike the case of locals where such lands are tansferable. However, there is a different rule for land acquired by non-locals for commercial or purposes other than subsistence farming. For one, a traditional token in the form stated earlier and cash are required before permission is granted. An allocation note is then given by the local chief with the approval of the district chief. Obtaining a lease by a stranger involves a trip by him or her to the Lands Commission, providing the necessary documents and abiding by its rules as explained in chapter 6 .

The customary land tenure system is a symbol social justice and equity in land allocations. This is derived from a tradition in which every shares and no one is alienated from the land (Kasanga, 1995). However, Urbanisation has brought about some changes in people's relationship to the land in Tamale. It has increased the value of land and has consequently led to the creation of a lucrative land market which has altered the roles of the chiefs as traditionally expected (see chapters 6 and 7). Land is frequently being appropriated by chiefs at the expense of their community members (Ubink and Amanor, 2008; Ubink and Quan, 2008; Yaro, 2010). The supervisory role of public land agencies in customary land administration and management is also challenged by chiefs who believe that they should not be held accountable by anyone (Kasanga, 2001). Traditional land laws have now been reconstructed by chiefs to facilitate sales of agricultural land for personal gain, with negative impacts on urban and periurban vegetable farmers who have been forced to intensify their practice to cope with decreased lands each season. Farmers who have lost part or all of their lands (as shown in 
Figure 3.4) are moving to peri-urban areas in search of land and water as discussed in chapters 6 and 7.

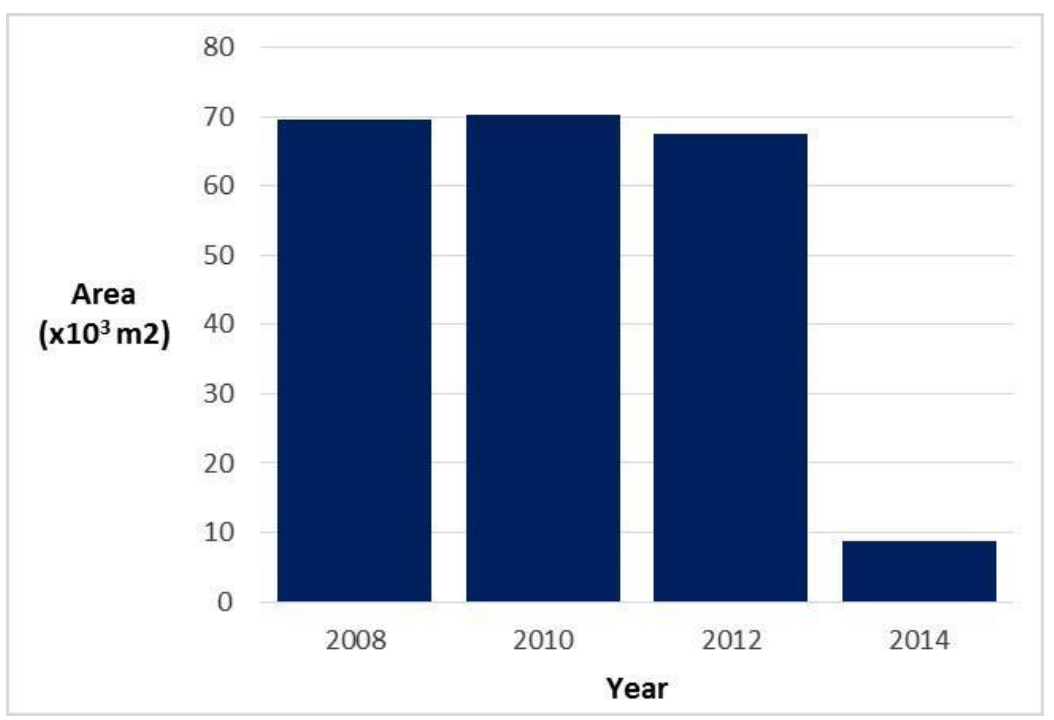

Figure 3.4: Effects of land commodification on cultivated land area at Buipela site Source: Author's fieldwork, 2015

The current land administration system in Ghana is the product of power dynamics between the state and the chieftaincy institutions dating back to the colonial time period. Power shifts and frictions between the state and chieftaincy institutions have resulted in limited accountability by the latter to the community and to the state as discussed in chapter 5 . In addition, the outdated urban planning laws in Ghana did not match the pace of population increase in Tamale and has, as a result, facilitated a land and housing crisis. However, there is currently a call for the adoption of a new urban planning law that incorporates all stakeholders involved in the use and administration of land in parliament. At the municipal level, a stakeholders meeting facilitated by RAUF under the UrbanFood ${ }^{\text {Plus }}$ project took place in Tamale. The aim of the meeting was to arrive at a policy narrative through a democratic dialogue for the purpose of integrating urban agriculture into city planning.

So far, this chapter has given a background of the socio-economic and geographical features of Tamale and their effects on urban agriculture. The following section explains how this author's fieldwork was carried out. It also explains the methodology used as well as the data collection techniques employed. Details of the sampling technique used in getting participants for the study are discussed in addition to how the collected data was analysed. 


\subsection{Fieldwork}

This section describes the author's preparation and field experiences. It also examines my position as a researcher in the field. Research validity, reliability, and ethical considerations are also being discussed. Sampling techniques and analysis used are also elaborated on.

\subsubsection{Methodological considerations}

This research was carried out using an emic and inductive approach. In seeking a research methodology that would provide an ontological and epistemological fit with the research under study, two paradigms were explored. These are the interpretivist paradigm and the constructivist paradigm. I employed them because they refute the existence of an objective reality and consider knowledge as constructed (Bryman, 2012). Max Weber was an advocate of interpretivism with his concept of verstehen, which aimed at understanding the meaning people attach to their actions in order to arrive at a causal explanation. Critics of verstehen have labeled it subjective, stating that for one to understand the action of another, one has to rely on an unverifiable intuition of the observer. Weber agrees that verstehen is subjective but maintains that the aim is to find out what the actor meant in his action and not the meaning the action has for the observer.

This idea fits with the concept of phenomenology, which is concerned with how individuals make use of the world around them. It calls for a need to see things from an actor's v point of view in order to understand his or her behaviour (Embree, 2015). According to Guba and Lincoln (1989), realities are social constructions of the mind and many of such constructions exist. Schutz (1954: 266-67), heavily influenced by Weber's verstehen, states:

The world of nature as explored by the natural scientist does not "mean" anything to molecules, atoms, and electrons. But the observational field of the social scientist - social reality- has a specific meaning and relevance structure for the beings living, acting, and thinking within it. By a series of common-sense constructs they have pre-selected and pre-interpreted this world which they experience as the reality of their daily lives. It is these thought object of theirs which determine their behavior by motivating it. The thought object constructed by the social scientist, in order to grasp this society reality, has to be founded upon the thought object constructed by the common-sense thinking of men living their daily lives within their social world. Thus, the construct of the social sciences are, so to speak, constructs of the 
second degree, namely constructs of the construct made by the actors on the social scene, whose behavior the social scientist has to observe and to explain in accordance with the procedural rule of his science.

From that perspective, knowing the motivations behind an action is crucial to understanding it. My research work takes into account Hayes and Oppenheim's (1997) caution that there exists a subjective inter-relationship between the researcher and the informant, a relationship through which meaning is co-constructed. I am also in agreement with De laine (1997) and Guba and Lincoln (1989) that my humanness is part of my research outcome. I address this issue in my data collection by presenting the voices of the informants. I also acknowledge the need to familiarise oneself with the field and research under study. It is for this reason that I, in the words of Mills et al. (2006), immersed myself in the knowledge of the respondent in order to be theoretically sensitive. Through a continuous interaction with the data, I hope to give it the necessary meaning that it deserves.

For the purposes of this study, immersing myself into the knowledge of the respondents allows me to better appreciate and understand the behaviours and interests of stakeholders involved in resource governance. Based on the research objectives stated in chapter 1, which is to understand how farmers access and manage resource and commodity flows. The interpretivist and constructivist methodology will be integrated with quantitative methods like Geographic Information System (GIS) techniques, which are useful for spatial analysis (Myburgh and van Niekerk, 2014). Quantitative data was used to triangulate and validate some of the qualitative data collected from farmers through interviews and focus group discussions. The next section explains how the research work was conducted with an eye towards validity and reliability.

\subsubsection{Research validity and reliability}

Although reliability and validity are concepts mostly associated with quantitative studies, (that is, positivist epistemology), currently they are employed in qualitative research studies (Golafshani, 2003). Reliability in this context refers to the ability for a research to be replicated or repeated whereas validity is mostly concerned with the accuracy and trustworthiness of a research findings (Winter, 2000). In qualitative research, truth and value are spoken of instead of validity, which is based on the recognition that multiple realities exist. Hence, the researcher outlines personal experiences and viewpoints that may have caused methodological bias and clearly and accurately presents participants' 'perspectives' (Noble and Smith, 2015). Reliability in qualitative terms constitutes a function of consistency relating to the 'trustworthiness' of the data collected. 
In this context it is important that a researcher's decisions are clear and transparent and that an independent researcher can be able to arrive at a similar finding. Neutrality or confirmability is only achieved when issues related to truth value, consistency, and applicability are addressed. For the sake of accuracy, it is important for the researcher to acknowledge "the complexity of prolonged engagement with participants and that the methods undertaken and findings are intrinsically linked to the researchers' philosophical position, experiences and perspectives" (Noble and Smith, 2015: 34). These elements are accounted for by the author and have been differentiated from participants' accounts. In qualitative studies, the approach towards reliability and validity is different as it seeks understanding and illumination instead of measurements (Stenbacka, 2001). Morse et al. (2002) have argued that to separate fiction from scientific research, there is a need for rigor. Although quantitative concepts of validity and reliability cannot be used in qualitative research since they have different philosophical and methodological positions, there is a need to put in place some criteria for sound social research (Noble and Smith, 2015).

Alternative concepts suggested for asserting rigor in qualitative research by Lincoln and Guba (1985) are truth value, consistency, neutrality, and applicability as explained above. Morse et al. (2002) and Golafshani (2003) talk about credibility, neutrality or confirmability, consistency or dependability, and applicability or transferability. Triangulation is a test for evaluating the reliability and validity of any study (Golafshani, 2003). It also strengthens a study by combining methods (Patton, 2002). Moreover, since reality is ever changing and there exist multiple realities, the use of multiple methods of gathering data, as done in this study, is important (Johnson, 1997).

Data was collected through a variety of means including in-depth interviews, informal conversations, and focus group discussions. This took into account the different social realities in the study area, and the effect on farmers as they attempt to access, maintain and control resources like land, water, and seed in their farm practice. Respondents were asked why they used certain access routes, what the alternatives were, and how access was gained. Notes and recordings from interviews and focus group discussions were transcribed and relevant themes and concepts noted and grouped. Additional focus group discussions and in-depth interviews were conducted to discuss themes noted before to ensure clarity and make room for consistency.

Information gathered was then triangulated using a quantitative spatial data collected with a GIS device. For the data to achieve a truth value, be consistent, and applicable the researcher acknowledged the existence of multiple realities and accounted for that by using multiple data collection methods. The data collected was also taken back to the informants for clarity and consistency. To avoid philosophical and methodological bias, the researcher, I present the participants opinions in their own words and I also immersed myself into the data 
and frequently checked in with participants for clarification. In the next section, the focus will be on the researcher's positionality and reflexivity during and after the research.

\subsubsection{Researcher positionality and reflexivity}

As already mentioned, there exists a subjective relationship between the researcher and the informant and as a result, data collection processes and research findings could be biased (Golafshani, 2003). Field research is a co-constructed space occupied by the researcher and her informants. Both parties have multiple overlapping identities which could result in different meanings from various aspects of their identities (Bourke, 2014). Thus, a researcher's positionality and reflexivity are essential to the production of data that is theoretically sensitive and an accurate representation of informants' views. Reflexivity here entails a continuous selfanalysis and scrutiny on the part of the researcher and his/her acknowledgement of a professional relationship with the informants (Pillow, 2003). Positionality stems from the outside/insider considerations.

With regards to the insider-outsider distinction by Bourke (2014), it is worth your knowledge that this researcher is an outsider; that is, neither a native of Tamale nor a Ghanaian. As an outsider, she was considered by the informants as a vessel through which their voices could be heard - as one who will tell their story the way they say it without bias because she is not from the area, but trusted. Some power dynamics were at play given my circumstance as the only woman working with mostly male farmers. This gender dynamic had a positive effect on my working relationship with the farmers who were impressed that a woman could do vegetable farming, an activity which they considered too technical for females in this study area.

The personal networks of my research assistants built through their works in a capacity for other researchers proved useful in building and strengthening trust between myself and the farmers. Those networks benefited my research in ways that mirrorThuo`s (2013) description of his research experience in Nairobi, Kenya. Among some of the things my assistants did include the use of their personal contacts to get me access to respondents through the Sagniregu District Chief Executive (DCE) and other senior staff members of the district assembly.

Generally, before any interview my assistant introduced me as a 'Cameroonian researcher studying in Germany, who has decided to do fieldwork in Ghana' and afterwards he explains the purpose of my research. This was very important to the informant since it gave them an idea of what my research was about. During this introductory phase, the informant's consent is sort and confidentiality assured. Most of the research with farmers was carried out in the Dagbani language. That is, I asked the questions in English and then it was translated to the farmers by my Dagbani and English speaking research assistants who translate the 
former's response to me in English. This made most of the informant comfortable since they could express themselves better in their own dialect. However, I acknowledge the fact that such an arrangement opens the possibility for information to be twisted. It was for that reason that I conducted some in-depth interviews in English for verification purposes and corresponded with other researchers with experiences with the same farmers that I interviewed.

In this study, the positionality of the assistance is relevant as an insider, as was the case of early anthropologists, who could not speak the dialect of the people and so got insiders as interpreters. In following the footsteps of early anthropologists, I got a better understanding of the issues from the insider position of my assistants. This advantaged was weighed against potential biases that my assistants might have had which could have affected how they relayed certain information. After spending about fourteen months in this study area separated by a three-month break in Germany, I agree with Visser (2003) that the duration of fieldwork can blur the insider-outsider distinction. During the last leg of my fieldwork, I established a close relationship with many of my respondents which allowed me have informal conversations and interviews with them about issues we had previously discussed for better understanding.

My short visit to Germany was also important because it gave me time to do more research on the subject using the preliminary data I had collected. It also gave me the opportunity to discuss my work with other colleagues and my supervisor. It was a chance to rearrange my data and make sense of what the data was telling me. I was also able to distance myself from the field and look at the data with an 'objective lens.' When I returned to the field I was inspired to ask more clarifying questions and delve into fruitful themes. From the information given above, it can be said that the researcher's positionality and reflexivity throughout the research process impacted on the quality of data gathered. My assistant's position as an insider also gave me access to traditional authorities and elders with whom I developed a close relationship and as a result I was able to get their own interpretation of how resource politics has played out over time on vegetable sites in the study area.

This examination of the research process in the context of my positionality can be described, at least in part, as reflexivity. Thus, if reflexivity is said to be "a continuing mode of self-analysis" as stated in Callaway (1992: 33), then the methodological approaches that I undertook in collecting and analysing data can be described as such. Visser (2003) and Bourke (2014) argue that the insider-outsider conceptualisation with regards to a researcher's positionality is not static but instead, it is dynamic across time and space. They argue that the political atmosphere at a given time and place has an effect on the responsiveness of the informants in relation to the questions posed. This is seen when respondents in government offices shy away from the use of recorders during interviews or refuse to cooperate at all for fear that they may be secretly recorded. According to Bourke (2014), the insider-outsider bi- 
nary should not be focused upon at the expense of transparency to respondents by the researcher regarding his or her position. This I believe I have done. Also important are some ethical consideration which no research work can be conducted without. I have outlined below some of the ethical considerations that I gave over the course of my field research.

\subsubsection{Ethical considerations}

Ethical issues are an integral part of any research, whether it is with regards to human or animal informants (Bryman, 2012). This is because the researcher needs to collect personal data and the informant's right to privacy and dignity has to be maintained (Žikić, 2007). Ethical guidelines or rules are meant to secure the informants from any socio-cultural or political harm that could result from his or her cooperation (Meadows et al., 2003). There are some general principles that every researcher is expected to adhere to when carrying out research. These principles include informed consent, voluntary participation, anonymity, confidentiality, respect for respondent's privacy, and no deception (Bryman, 2012). According to Žikić (2007), it is imperative to clearly state the nature of the research in its entirety to the informants. The informants are supposed to be reminded at all stages that they have a right to leave at any time during their encounter with a researcher. Anonymity and confidentiality are also important; data should sometimes be kept separate from the identity of the informants. When data is made public, it could take the form of a pseudonym when the information is sensitive and could potentially put an informant in harm's way. While I did not keep the identity of the informants completely separate from the data, a pseudonym was used where the information received was sensitive.

Informed consent is the first step towards building a cordial and trustworthy relationship with informants at the start of any field work. This is because it entails informing the informants about the aim of the research, its effects, the confidentiality code, and the voluntary basis of their cooperation. This leaves open the possibility of a negative or positive response when an informant's consent is sought (Miller and Boulton, 2007). Once an informant gives his consent, the researcher is ethically bound to these terms throughout the research process (Miller and Bell, 2002). During this study as mentioned in section (3.3.1.3), I informed all informants about my research goals and while some gave me their consent, others did not. Some of those who did not cooperate with me include locals who felt they were abandoned by previous researchers who promised to help them in one form or another following their cooperation. They gave examples of researchers who used information obtained from them to apply for funds on their behalf that did not in actuality benefit them.

I complied with the ethical considerations stated above by explaining the purpose of my research to my informants, the likely consequences of their cooperation with me, and how data will be collected. I also presented some information on the funders and collaboration with 
other colleagues in the project. I informed some of them about how data obtained from them will be treated. Permission was granted and consent was given to taking pictures and shooting videos for scientific and public purposes. The informants were given the opportunity also to ask questions for clarification before an interview was started and they expressed their preferences which wes duly noted and adhered to by the researcher.

In the next section, I follow up on the different research techniques I used in gathering data, starting from the preparatory phase in Germany and the fieldwork proper in Tamale, Northern Ghana. The following section also explains my choice of research data collection tools, the sampling methods utilised, and how data was analysed.

\subsection{Research methods and data sources}

This section details the preparatory phase of my research work in Germany. It gives a summary of the baseline survey organised by all the sub-projects, and this served as part of my preliminary data. It also describes the different data collection techniques used their relevance to this study. This thesis is built on data collected from October 2013 to March 2014 and July 2014 to February 2015.

\subsubsection{Preparatory phase in Germany}

During my preparatory phase for fieldwork in Germany in the months of June, July and August 2013, extensive literature research was carried out on the effects of structural adjustment programs on the agricultural system in Ghana. I studied the historical evolution of agricultural policy in Ghana from the colonial era to the present. I also pored over numerous documents on urban agriculture and its relevance to the government and smallholder farmers in Northern Ghana. I attended doctoral colloquiums and a summer school where I had the opportunity to present my research idea and receive comments and criticisms that later became useful to my work. I also communicated with experts, potential research assistants and others on the field prior to my visit. Furthermore, I attended a number of colloquiums on theories and concepts relevant to my research work. All of these helped shape my ideas for this research in a very significant way. This ties in with Mills et al. (2006: 4) argument that a researcher should not enter the field as a blank slate.

\subsubsection{Baseline survey}

I left Germany for the field on the $31^{\text {st }}$ of August 2013. A baseline survey and participatory research for the overarching UrbanFood ${ }^{\text {Plus }}$ project had to be carried out before each doctoral fellow carried out their individual studies. As part of the baseline team, we engaged in quantitative and qualitative data collection. A closed-ended standardised questionnaire was used in gathering socio-demographic data in Tamale, Ghana, and Ouagadougou, Burkina Faso along 
a continuum. This was intended to collect data on crops grown, animals kept, soil properties, cultivated area, land ownership, wealth, and the statuses of farmers. These information was collected after a randomised sampling using ArcGIS with open space fields and backyard farms. Qualitative data using participant observation, open-ended interviews, informal conversations and focus group discussions were used to understand how farmers negotiated access to resources for farming and technology adoption. This activity was mainly done by the Anthropology sub-project. In carrying out the qualitative data, participants were purposively sampled. We selected informants who were willing to talk to us in areas where the quantitative data was collected. This qualitative data was meant to complement and explain the findings from the quantitative data.

In carrying out the baseline survey, I visited many open space vegetable and rice fields in urban and peri-urban and government irrigation sites where data was later collected for this thesis. I joined the farmers on several occasions while they raised ridges and irrigated their vegetable farms. We had informal conversations about how land is accessed for residential and agricultural purposes. We discussed the customary land tenure system and their impressions on the ways land was administered by their chiefs. I noticed the farmers were pleasantly surprised by my ability to raise a ridge, an activity which is uncommon for females in their community.

During these visits and talks with the farmers, I was informed about the strategies employed by farmers to gain and maintain access to resources necessary for farming. I also came across many agricultural innovations and information on how they came about I sort to understand why they chose some technologies over others and the ease with which they adopted them. Land security and 'ownership' 15 were constant themes and I sort to understand their meanings from the farmers` perspectives which were different from their literal meaning. My research assistants Mr. Baako and Baba Alhassan accompanied me on those trips.

My participation in the baseline survey gave me a general idea about the dynamic processes inherent in the urban agricultural resource governance system and a basis on which I could comfortably start my doctoral research work. The following section discusses the different data collection techniques I used and their relevance to this study.

\footnotetext{
${ }^{15}$ My understanding of "ownership" before I went to the field was when one has a "legal right" over something. So, if one said he owned a piece of land. Initially I understood that to mean, he legally owns the land and has a deed or title to it. But later I realized that farmer's reference to ownership referred to usufruct rights to farm on all community land, when permission was obtained. This is discussed more in chapter 4,6 and 7 .
} 


\subsubsection{Overview of research methods}

After the baseline survey, I turned to data collection as my next main objective. I used a combination of methods in gathering the data for this thesis. The qualitative methods employed include informal conversational interviews with key informants, participant observation, participatory photography, focus group discussions, case studies, and stakeholder meetings. The quantitative spatial method used was the Global Positioning Satellite (GPS) tool to measure the open space areas under vegetable cultivation between 2008 and 2014. Farmers' recollection was triangulated using google maps and images from an unmanned anerial vehicle. The Unmanned Aerial Vehicle commonly or drone is a small aircraft controlled by remote and with which aerial views are captured. In addition to these primary sources are secondary sources from which information was gathered. The following describes each research method in detail and explain how it was used for gathering data for this study.

\subsubsection{Interviews}

Interviews are one of the most common data collection tools in qualitative research (DiciccoBloom and Crabtree, 2006). Face to face interviews are a valuable method of getting a rich description of a phenomenon from the interviewee's lived experiences (Seidman, 2006). Interviews could be structured or semi-structured. Most interviews with identified key informant are semi-structured and in-depth (Dicicco-Bloom and Crabtree, 2006). In-depth interview gives the researcher an opportunity to understand the meaning behind the informant's behavior and action, that is, it pits behaviour in the context and understanding of the action (Seidman, 2006). Key informant interviews are sources of expert information about a particular subject (Marshall, 1996). Key informants have been referred to as strategic and natural observers by Sjoberg and Nett (1968).

I used an interview guide when talking with informants as stated earlier. The questions I asked were open-ended allowed for new ideas to develop during the interviewing process. When valuable information was revealed, I followed the trend of the conversation and sometimes never went back to the guide. Many interviews were carried out during the baseline survey with farmers, sub-chiefs and government officials in the land and water sector to understand how those resources are owned and distributed in the community (Table 3.2). After the baseline survey, I scheduled in-depth interviews to understand certain interesting concepts and themes that $c$ related to access routes to land and technology adoption that came up earlier. These in-depth interviews led to continued interaction with data which provided multiple meanings and understanding of the study. I realized that each time I carried out an indepth interview, new information was revealed and sometimes I was forced to revisit past questions. Respondents for the in-depth interviews were identified through focus group discussions and participant observation. 
Informal interviews or conversations were carried out at various stages of the research work. First, they were conducted to generate information about subjects to be interviewed. They were also used when I wanted to discuss sensitive issues and get explanations for actions which informants were hesitant to talk about in the presence of a recorder or notebook. Informal conversations were also used when I needed clarifications on observations during field visits or in government offices. Informal interviews, according to Turner (2010), are 'the moment experiences' and what Gall et al. (2003: 239) refer to as “... spontaneous generation of questions in a natural interaction, typically one that occurs as part of ongoing participant observation fieldwork". Information on why few women took part in vegetable farming in the city during the dry season was gotten through informal conversations with farmers and my assistants after meetings, while travelling fields, and while at leisure with interviewees.

Key informant interviews were carried out with farmers, agricultural officials, irrigation unit staff, public land agencies, chieftaincy institutions, customary land secretariats, and nongovernmental organisations amongst others as shown in (Table 3.2).

Table 3.2: Interviews conducted during fieldwork by the researcher

\begin{tabular}{|l|l|c|}
\hline Interviews & Informants & Numbers \\
\hline Key informant inter- & -Public land agencies & 4 \\
views & -Traditional institutions & 5 \\
& -Ministry of Agriculture & 4 \\
& - Ghana water company Ltd & 1 \\
& -Northern Electricity Distribution Company & 1 \\
& (NEDco) & \\
& -Customary Land Secretariat & 1 \\
& -Urban Agricultural Network & 1 \\
& -New Energy & 1 \\
& -Vegetable farmers & 11 \\
& -Wet season farmers & 2 \\
& -Livestock keepers & 2 \\
& -District Chief Executive & 1 \\
& -Assistant Chief Executive & 1 \\
& -Agro-chemical dealers & 1 \\
\hline In-depth interviews & -Savanna Agricultural Research Institute & 1 \\
& -Vegetable farmers & 6 \\
& -Land Commission & 1 \\
\hline
\end{tabular}




\begin{tabular}{|l|l|l|}
\hline & -High court registrar & 1 \\
& -Urban Agricultural Network & 1 \\
\hline General interviews & -Vegetable farmers & 25 \\
& -Agro-dealers & 5 \\
& -Savanna Agricultural Research Institute & 2 \\
& -Italian Cooperative representative & 1 \\
& -Ghana Water Company staffs & 2 \\
& -Town and Country Planning Department & 2 \\
& -Survey Department & 1 \\
& -Local chiefs & 2 \\
& -Sub-chiefs & 1 \\
& -Gunza Development Association & 2 \\
& -Radio Station broadcasters & 3 \\
& -Irrigation Officers & 2 \\
& -Wet season farmers & 3 \\
& -Volta River Authority & 1 \\
& -Assemblyman & 2 \\
\hline
\end{tabular}

Respondents and sites were identified through snowball sampling with different subjects implicated in dry season vegetable farming. gathering information through different subjects including farmers, researchers, non-governmental organisations, government institutions and chieftaincy institutions in identifying respondents and vegetable sites reduced the possibility of the bias I would have had by using a single subject to reach the sites and respondents.

\subsubsection{Participant observation}

Participant observation is a traditional tool used by some of the earliest anthropologists including Bronisław Malinowski in his research on the Trobriand Islands (Taylor et al., 2015). Qualitative research is concerned with how people think and act in their everyday life. Participant observation is a method used by researchers to access information and gain understanding by interacting with informants in a natural and non-intrusive manner (Rossman and Rallis, 2012). According to Taylor et al. (2015), participant observation constitutes 'blending into the woods,' that is, grasping an understanding of the research setting. Through participant observation, the researcher is able to understand a subject's actions by observing through daily observation. After a year of using this method, the researcher comes close to getting the insider's point of view (Hume and Mulcock, 2004). 
I participated in the everyday lives of the farmers and had the opportunity to ask for the reasons behind some of their actions which I observed. This was routinely done at all the vegetable sites that were visited. After observing farmers' everyday practices, questions were asked through interviews and focus group discussions for a better understanding and also to get their perspectives. For example, through participant observation, it was clear that urban agriculture was male dominated in this study area and I wanted to know why. Using participant observation proved to be a great eye opener, as it gave me insight into the agricultural practices of the people and interviews conducted later deepened my knowledge of this practice.

\subsubsection{Focus group discussion}

Focus group discussions are carried out ideally in groups of 6-8 persons (Liamputtong, 2011). The aim of such a tool is to generate conversation with many persons in order to generate a variety of opinions on a particular issue (Cyr, 2016). It also provides a broad array of experiences, perspectives and an opportunity to ask for an explanation to responses or ideas raised (Morgan, 1996). Focus group discussions (FGD) are considered by Smithson (2000) as social events which yield data through interactions with a group of individuals making the information greater than the sum of its parts. Interactions in groups yielded different meanings and understandings, which was better understood after in-depth interviews were later conducted.

Focus group discussion also gives an idea of how different people understand phenomena and it also helps to mitigate problems of clarity (Moravcsik, 2014). For example, a question could easily produce two different answers, with each answer justifying the answer. Probing this further can produce information which is relevant to the research. This method was useful at explaining why some farmers choose different actors or institutions in their search for resources or why they used a particular discourse instead of another. A weakness of FGD is that some individuals react differently in public than they do in private. Some "exaggerate, minimize or withhold experiences" (Hollander, 2004: 626). This implies that group dynamics do shape how individuals react to questions (Farnsworth and Boon, 2010).

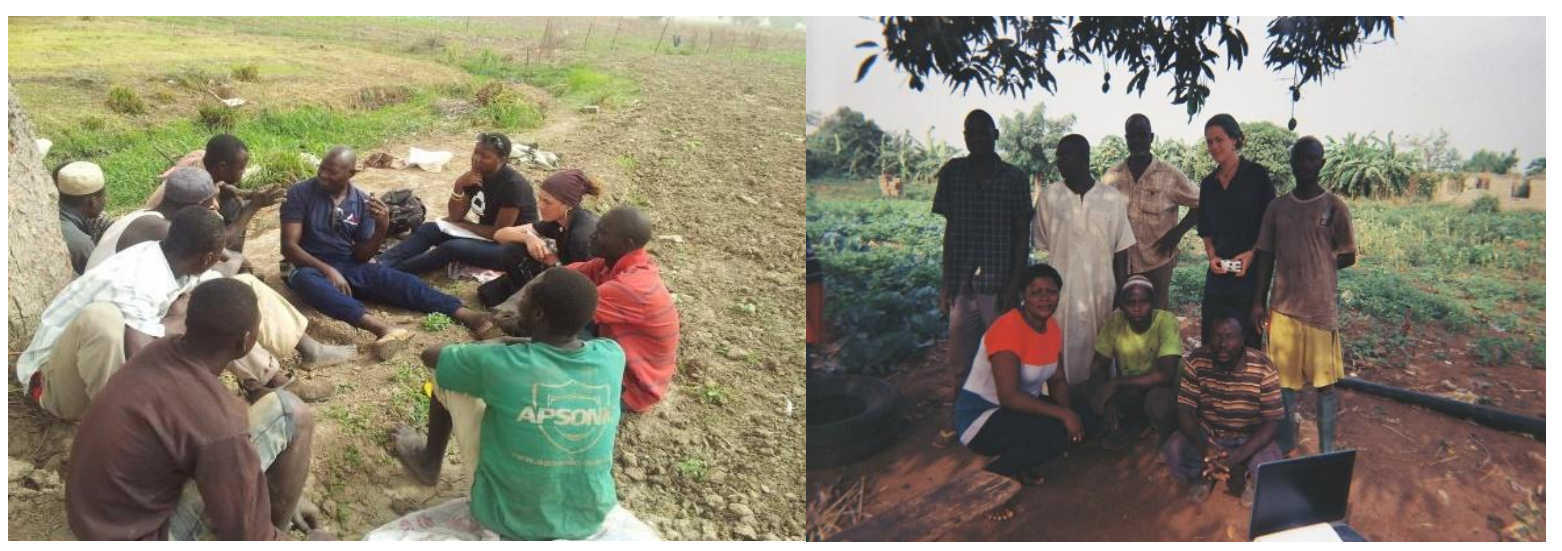


Figure 3.5: During and after focus group discussions in some vegetable sites Source: Author's fieldwork 2014/15

I carried out focus group discussions in all the vegetable sites in urban and peri-urban Tamale, as seen in Figure 3.5 above. These discussions focused on specific thematic issues and were followed up by an in-depth interview with some of the farmers later. Focus group discussions was a great source of information on contesting issues inherent in urban agriculture, and it gave me a different perspective on how farmers gained and maintained access to land, water, and seeds. In using this tool, I identified many technologies and questioned why and how they used one technology and not another. For example, during a focus group discussion with farmers at Gumbihini, I learnt that the Urban Agricultural Network and the Savannah Agricultural Research Institute researcher had provided them with pipe borne water, drip irrigation, improved seeds, and compost. They preferred pipe born water which was easy to use and efficient unlike the drip irrigation and improved seeds which were technical, and of which they got limited support from the donors after these technologies were introduced.

Three sets of focus group discussions were carried out. The first round of discussion was to understand the general agricultural practice of vegetable farmers and their social relations and networks. The second set of focus group discussion was carried out to measure the surface area of urban and peri-urban vegetable fields in the past six years, to triangulate and validate data from interviews which indicates that land used for vegetable farming has continuously been shrinking over the years. The last set of focus group discussion was participated by female vegetable farmers and the goal of the discussion was to understand how they got access to lands for farming and how they maintained control over it. In addition, I also wanted to know how they were first introduced to farming on irrigation sites.

Table 3.3: Focus group discussions conducted during fieldwork by the researcher

\begin{tabular}{|c|c|c|c|}
\hline $\begin{array}{l}\text { Focus group discus- } \\
\text { sions }\end{array}$ & Area & & Numbers \\
\hline $\begin{array}{l}\text { General farm prac- } \\
\text { tices }\end{array}$ & $\begin{array}{l}\text {-Choggu } \\
\text {-Buipela } \\
\text {-Zagyuri } \\
\text {-Dufa } \\
\text {-Kpenni } \\
\text {-Gumbih } \\
\text { (VRA) }\end{array}$ & $\begin{array}{ll}\text {-Forest reserve } & \text {-Fooshegu } \\
\text { - Stadium area } & \text {-Sangani } \\
\text {-Jekerayili } \quad \text {-Kambonayili } & \\
\text {-Nyanshegu } & \\
\text {-Gumbihini new dam } \\
\text { old dam - Gumbihini waterworks area }\end{array}$ & 15 \\
\hline Land use & -Choggu & -Buipela & 18 \\
\hline
\end{tabular}




\begin{tabular}{|c|c|c|c|c|}
\hline & $\begin{array}{l}\text {-Nyanshegi } \\
\text {-Kambonay } \\
\text {-Fooshegu } \\
\text {-Gumbihini } \\
\text {-Gumbihini } \\
\text {-Fuo }\end{array}$ & $\begin{array}{l}\text {-Sahapelgu } \\
\text {-Jekerayili } \\
\text {-Sangani } \\
\text { dam -Gumk } \\
\text { aterworks ar }\end{array}$ & $\begin{array}{l}\text {-Dufa } \\
\text {-Daitoyili } \\
\text {-SSNIT } \\
\text { hi new dam } \\
\text { (VRA) -Tunaayil }\end{array}$ & \\
\hline Women & -Golinga & -Gbelahigu & & 2 \\
\hline
\end{tabular}

\subsubsection{Participatory photography}

The proliferation of smartphones with cameras over the past decade has allowed people to capture their everyday realities and environment through photography. (Luttrell and Chalfen, 2010). This method asks informants for their stories and perspectives through the production of photographs and the interpretations they attach to them. It also gives participants an opportunity to tell their stories in their own ways (Yates, 2010). Informants were equipped with camerasby the author through which they could document their social landscapes. After the photos are taken, the next step is reflecting on the meanings behind them (Packard, 2008). Photography as a data collection is a mechanism that makes the informant and the researcher cocreators of knowledge (Coronel et al., 2013).

Finally, and in agreement with Allen (2012), it is important for the researcher to know what he or she is looking for before using this method. Knowing what I wanted allowd me redirect the discussion towards my interest thereby preventing unpleasant surprises and allows important moments to be captured. I used this method to understand farm dynamics and what farmers consider important in their practice and why. Farmers were put into groups of six and one of them is appointed by his team members to be in charge of the camera. He may also give it to any one of them who wants to use it It was agreed that they would decide on their own how and which pictures will be taken. This was done on eight vegetable farms. After the pictures were taken, they were spread out before the farmers in groups. Each farmer was asked to identify a picture that best describes what he does and why. The pictures selected and shown below capture some of the main concerns vocalized directly to me by the farmers regarding dry season vegetable farming as stated in the descriptions. 

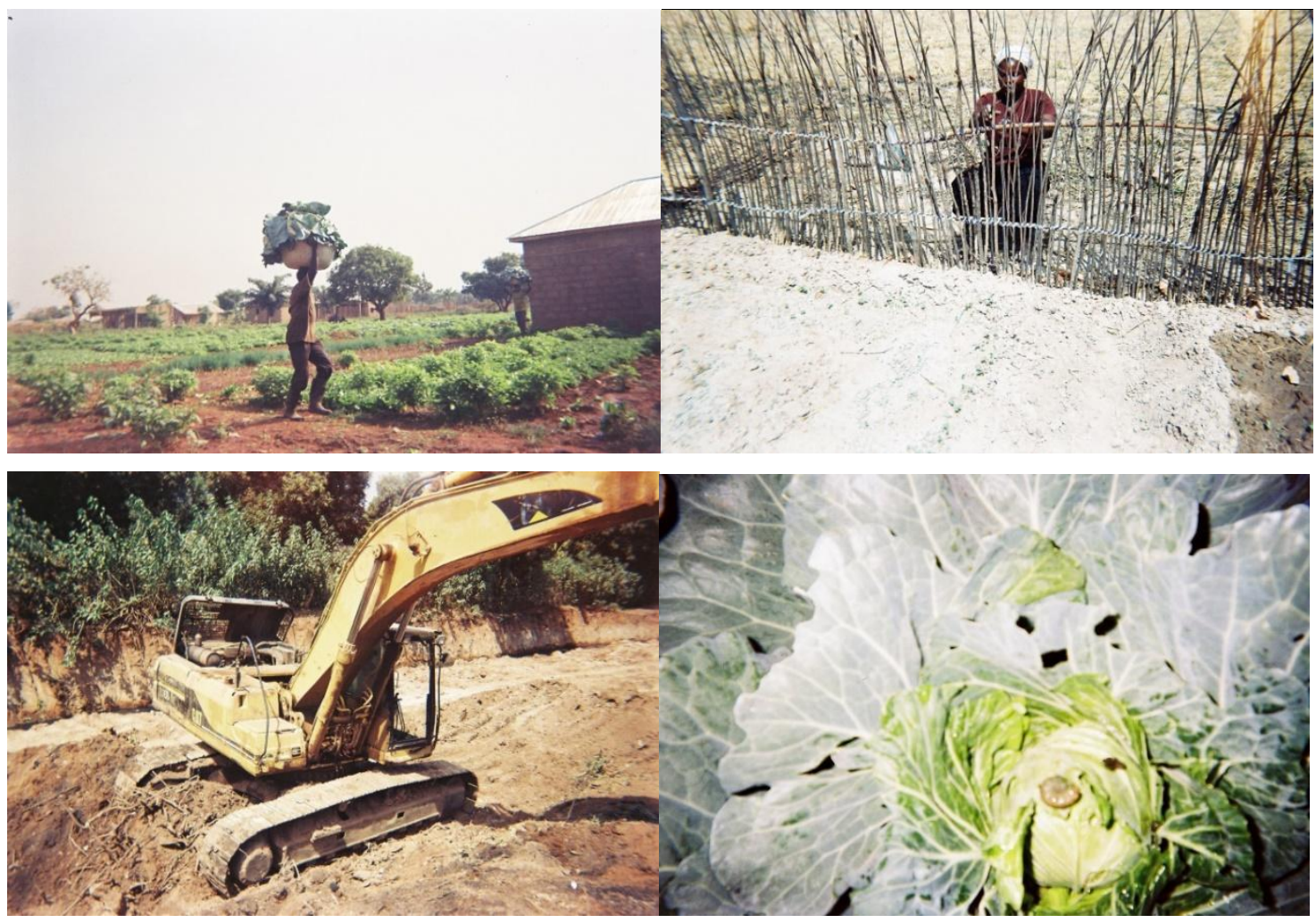

Figure 3.6: Pictures, showing farming practices by vegetable farmers in Tamale Source: Author fieldwork, 2014

Top left - customers are kings, so farmers need to do all in their power to keep them while maintaining a reasonable profit margin. They do this by giving their customers more vegetables as gifts and also by carrying their purchased vegetables to the nearest transport station. Top right - women are good helpers on the field but cannot be trusted with technical responsibilities like weeding and planting crops such as lettuce and cabbage. Fences are very important technologies or tools to keep out animals and stake ownership. Farmers use fences to stake their claims over a resource.

Bottom left - urban infrastructural development projects are taking away land previously used for agriculture. The machine was used to widen gutters around the Gumanai- Fuo- Tunaayili area. The aim of these development projects is to prevent water from collecting into gutters during the wet season. However, in the dry season, these gutters are water sources for dry season vegetable production. Therefore, urban planning not only reduces agricultural land, but it also takes away important sources of water for vegetable irrigation during the dry season. Bottom right - Pests are another threat that farmers have to contend with. They cause both physical and financial damage to farmers and because they are such a common threat, farmers are sometimes forced to use pesticides that are more appropriate on cotton plantations on vegetable farms. This has caused serious health complications of various kinds for farmers and consumers. 
Other pictures touched on different themes that important to this study. They touched on issues regarding pests, consumer relationships, infrastructural developments, and household relations and how they affect vegetable farming. In the following section, I build my cases for this study.

\subsubsection{Case studies}

In seeking to understand how farmers gain, maintain, and control access to resources in their agricultural practices, I visited a number of farms and had informal conversations and interviews with their owners. I asked how they acquired the lands they were farming on and how long they had been farming on them. I asked the farmers to explain how plots of land were distributed amongst themselves at different sites and the reasons for any distributional discrepancies. I also observed and participated in farm activities including irrigating vegetables and building ridges. In one of the discussions with the farmers, I learned that multiple actors had claimed ownership of lands close to the city center that were used for vegetable cultivation. This led me to conduct an extensive case study in line with Mitchell (2006) and Gluckman (1940) to ascertain why and to also gain a better understanding of how land is accessed, used, and managed.

The first case study involved three open space vegetable sites in Central Tamale. These sites include the Gumbihini old dam, the Gumbihini new dam, and the Gumbihini waterworks areas or former VRA. These are among the biggest vegetable sites in the area and multiple actors are in competition for control over them. Traditional leaders were in charge of these lands since under state law land no longer in use falls automatically under the control of the chiefs. However, other actors including the Ghana Water Company limited (GWCL) and Volta River Authority (an electricity company now referred to as Northern Electricity Distribution Company (NEDCo)) also claim to have rights to at least parts of the same lands - rights which they claim to have acquired through compulsory land acquisition exercises initiated to provide vital public services to the people.

To build up my cases, I conducted in-depth interviews and focus group discussions on different themes like resource access, management practices, and technology adoption at the various vegetable sites. I also carried out participatory photography to get a 'thick' description of farmer's management practices and their strategies to maintain their livelihood. I used interview guides to clarify and triangulate information already collected. I also visited with the traditional authorities to learn about the history of land use and ownership in the region. I asked local chiefs how land is acquired and what the different procedures are and compared their responses with the information I obtained from officials at the various public land agencies.

Land dispute case files were studied with subsequent interviews held with the registrar of the high court and the commercial court clerk. I corresponded with lawyers for the different 
parties to the dispute including government institutions like the Land Commission, Ghana Water Company, and the Volta River Authority to get a clearer picture of how the judiciary system functioned alongside customary laws in land dispute cases. I also had several key informant interviews with non-governmental organizations, staffs of the metropolitan assembly, as well as the regional and local agricultural officers. For informal conversations, I visited with the farmers at their homes as a sign of friendship and solidarity with their needs. I participated in funerals and naming ceremonies. I also welcomed many farmers at my place of stay who often brought with them vegetables from their farms for me to use. Before our meetings I offer them the customary soft drink offered to visitors as a sign of welcome in the Dagomba tradition. This practice of hospitality and reciprocity created a bond of friendship which eased data collection. I was no longer looked at as a foreigner but I was referred to as a sister. This opened up avenues of trust and more in-depth information. For example, during a conversation with a farmer, he said "I am talking to you because you understand our culture and can help us; you are not like the "white" researchers who do not have respect for our culture or our agricultural extension workers who do not help us".

\subsubsection{Meeting places as political arenas}

I attended a number of meetings including a farmer's union meeting organised by the Urban Agricultural Network in 2014, a stakeholders meeting organised by the Resource Centre on Urban Agriculture and Food Security on urban agriculture in 2015. I also attended a metropolitan assembly meeting on the importance vegetable farming in 2015 combined with a technical meeting on integrating fish farming as a component of urban agriculture in the proposed Gumbihini new dam in 2015. I also collected minutes of land disputes from the national archives in Tamale and had a discussion with a colleague about other stakeholder meetings which I did not attend.

Land disputes meetings are of particular interest to this thesis because they are local arenas where 'talking claims' are made Land disputes could be between two people or groups of individuals and between the former and the latter and an institution as explained in the extended case study on Gumbihini in chapter 7. Meetings are forums for conflict mediation and where wrongdoers are punished. Meeting settings are also occasions for political tussles, power struggles, and government in action. They are places where hybrid governing systems are combined for the resolution of issues critical to individuals and society. During stakeholder meetings, different claims to resource were expressed and solutions to have access to landed property proposed. Different access routes to resources for vegetable farming were suggested by the participants and options for a legalised solutions discussed.

These stakeholder meetings are arenas where the authorities of different politico-legal institutions are acknowledged and their recognition of claims are sought by individuals or 
groups. The meetings open up possibilities for forum shopping and institutional shopping as explained by Benda-Beckmann (1981) and Bierschenk and Olivier de Sardan (2003) and illustrated in chapters 6 and 7. I also attended the vegetable farmers' union meetings organised by a non-governmental organisation that is very active in aiding farmers to secure resources for vegetable production. As a partner working with farmers to secure lands and gain access to water and seeds, it has acquired legitimacy from the public as an organization worthy of funding. In-depth and key informants' interviews were carried out to delve deeper into the meanings attached to the socio-political processes that take place in these arenas and how struggles for power and authority at these meetings affect farmers' access and control over resources for vegetable cultivation.

My meetings with the municipal assembly and technical team about the creation of a new reservoir to promote urban agriculture was largely about development. Specifically, about developmendiscourses that were introduced by transnational actors such as the Italian Cooperative as described in Ferguson and Gupta (2002), which inspired grassroots self-help movements that played important roles in providing social services to members and the community. By getting involved with this project, the state also re-establishes its role as the social benefactor of the people. The next section explains how spatial data was collected and how it added value to the qualitative data in this study.

\subsubsection{Spatial data}

A global positioning system (GPS) was used to capture the surface areas of open space vegetable sites that were under cultivation between 2008 and 2014. This was done to find out if this urban farming system is temporary or permanent. The spatial data was triangulated using images from Google maps and an unmanned aerial vehicle (UAV) to corroborate information obtained from farmers' recollection of farm sizes over the years. In addition, GPS points of some purposive cabbage backyard and open space farms were also collected. This spatial and aerial data were then analysed using an Arch GIS software. The spatial data was collected to validate qualitative data from farmers that suggested that open space vegetables sites were shrinking as a result of appropriation by local chiefs. It was also done to confirm whether farmers were moving to peri-urban fringes and opening up new vegetable sites as information from the various interviews suggested. During this exercise, I conducted informal conversations during which I asked for the changes witnessed in each vegetable site and the reasons why. This was followed by focus group discussions organized to uncover how the activities of the local chiefs have vegetable production. I also conducted interviews with chiefs to figure out why more lands were being sold now than ever before. In addition to the primary data, I also consulted with some secondary data in order to contextualize the primary information I obtained. 


\subsubsection{Secondary data}

Secondary research involves a search for existing data on a research subject. It is usually consulted to enlighten the researcher on what has been done and what is still left to do or how to improve what has been done. Secondary data sources are found in archival publications, statistical systems, scholarly publications or unpublished data obtained either online or in physical form (Whitehead, 2005).

I used secondary data to get an idea of the geography of the place and to familiarize myself with studies already done on urban agriculture in Ghana, Africa, and in other places around world. After collecting the preliminary data, I returned to Germany to read more secondary literature and analyze the preliminary information I had obtained. Secondary data sources were employed to contextualize the data. Secondary data was obtained from the archives in Tamale courts in Accra and Tamale, unpublished and published data from libraries and online, Ghanaian land laws and also letters to land agencies on land conflict related matters. The following section explains the sampling method used for this study.

\subsection{Sampling}

This research was carried out in urban and peri-urban vegetable fields in Tamale. The terms urban and peri-urban are ambiguous and defining them is not easy. When one thinks of urban images of a developed or built up area with good transport network and high population density comes to view. However, this is not necessarily the image in many urban areas across the African continent. According to Andranovich and Riposa (1993), an urban area is characterised by a dense population, social networks, high concentration of living spaces and a variety of economic activities. The population size usually ranges from 2500 to 50,000 people. According to Drechsel et al. (2006), Adam (2001) and Moustier (2001), urban areas are considered administrative centers. Drescher and laquinta (2002: 5) went further to define urban areas as a "statistical concept defined by a country's government." This definition leaves a lot of room for flexibility although it most likely takes into account features regarding population size, density, political and economic activity.

Peri-urban areas have been defined in Chagomoka et al. (2015a) as areas not more than $40 \mathrm{~km}$ from the urban center. Adam (2001) proposes a similar range of 30-40 km from a city center and Moustier (2001) argues for a $50 \mathrm{~km}$ distance from the city center. Simon et al. (2006) refer to peri-urban areas as a dynamic interface between the urban and rural area with no particular reference to its geographical location. In this study, I consider an area urban or peri-urban in the same vein as Laquinta (2012); that is, based on its classification by the government and in this case the Ghanaian government. All vegetable sites in urban and periurban Tamale were identified through snowball sampling, with city officials and staffs at the 
University for Development Study (UDS), I identified other sites. When I got to these other sites through more interviews and focus group discussions, I was informed about the existence of additional vegetable that I was unaware of. Altogether, I identified twenty open space dry season vegetable sites and two irrigation sites as shown in chapter 6 . Key informants for indepth interviews were selected purposively. Case studies were built from the data obtained from in-depth interviews, informal conversation, focus group discussions, and secondary literature.

When new information came up, I adjusted the participant's list by adding new informants to my research list Key informants in the government sector were selected for interviews as a result of their interactions with farmers in accessing agricultural resources like land, water, and seed. Information about them was obtained through snowballing with farmers, non-governmental organizations and the Regional Agricultural Ministry. Information on non-governmental organizations associated with agriculture was obtained from UrbanFood ${ }^{\text {Plus }}$ partners in Tamale including UDS and my assistants. Through conferences at UDS, I also received additional information through presentations and discussions with other colleagues working on urban agriculture in Tamale. I targeted mostly sub-chiefs and regents in my attempt to gather information about land use and management because of the unnecessary bureaucracy in meeting with district chiefs. Also, informal conversations with community elders revealed that sub-chiefs and the linguist of the local chiefs had more information on how land is transacted than the district chiefs themselves. This, according to them, was $s$ due to a Dagbon custom that physical restrict the district chief to certain areas. This means physical land transactions are done mainly by secretaries, relatives and linguists of chiefs. Information on how spatial data was sampled can be seen in section 3.3.3.7.

By using a mixed method, I gained an extensive understanding of both methods and avoided the problems associated with using only one method. This technique also provided a possibility for triangulation which allowed me to identify aspects of phenomenon more accurately by approaching them from different angles. The next section explains how data collected was analysed during and after field work.

\subsection{Analysis}

Analysis was done from an emic perspective in which an inductive reasoning (see section 3.3.1) was used to identify relevant patterns, categories, and relationships through a process of discovery of participants' views as prescribed by Schutt (2012). Here, I was interested in analysing cases in the research project as wholes and not as since the whole is larger than the sum of its parts. The analysis started from the data collection stage and continued throughout the research process. 
I took notes and made conceptual inferences as data was collected. Interview recordings were mostly transcribed personally in order to immerse myself into the data. Due to a continues self-analysis of my work, information from interviews and informal discussions were later reexamined during focus group discussions and vice versa to compare data gotten and recheck meanings attached to descriptive data. The aim of this activity was to ensure that the data best described the social realities of the farmers as communicated by them.

This process or what Parlett and Hamilton (1976) and Sinkovics and Alfoldi (2012) refer to as progressive focusing was repeated throughout the research process. After the process was completed, important themes and concepts contained in the notes and descriptive data were identified and continuously refined as new information emerged. For example, through discussing preliminary data with colleagues on and off the field, the information I received gave me new ideas about what to look for next time I was on the field. Through this process, new ideas and information cropped up modifying old themes and concepts as expected by Anderson (2003; Maxwell, 1996).

New themes and concepts were continuously refined to fit new information obtained till the researcher gets to the point of theoretical saturation. Theoretical saturation here does not only entail reaching a point where the researcher has 'heard it all.' According to Morse (2015: 587), theoretical "saturation is the building of rich data within the process of inquiry, by attending to scope and replication, hence, in turn, building the theoretical aspects of inquiry." Data was analyzed as per Figure 3.7 below. 


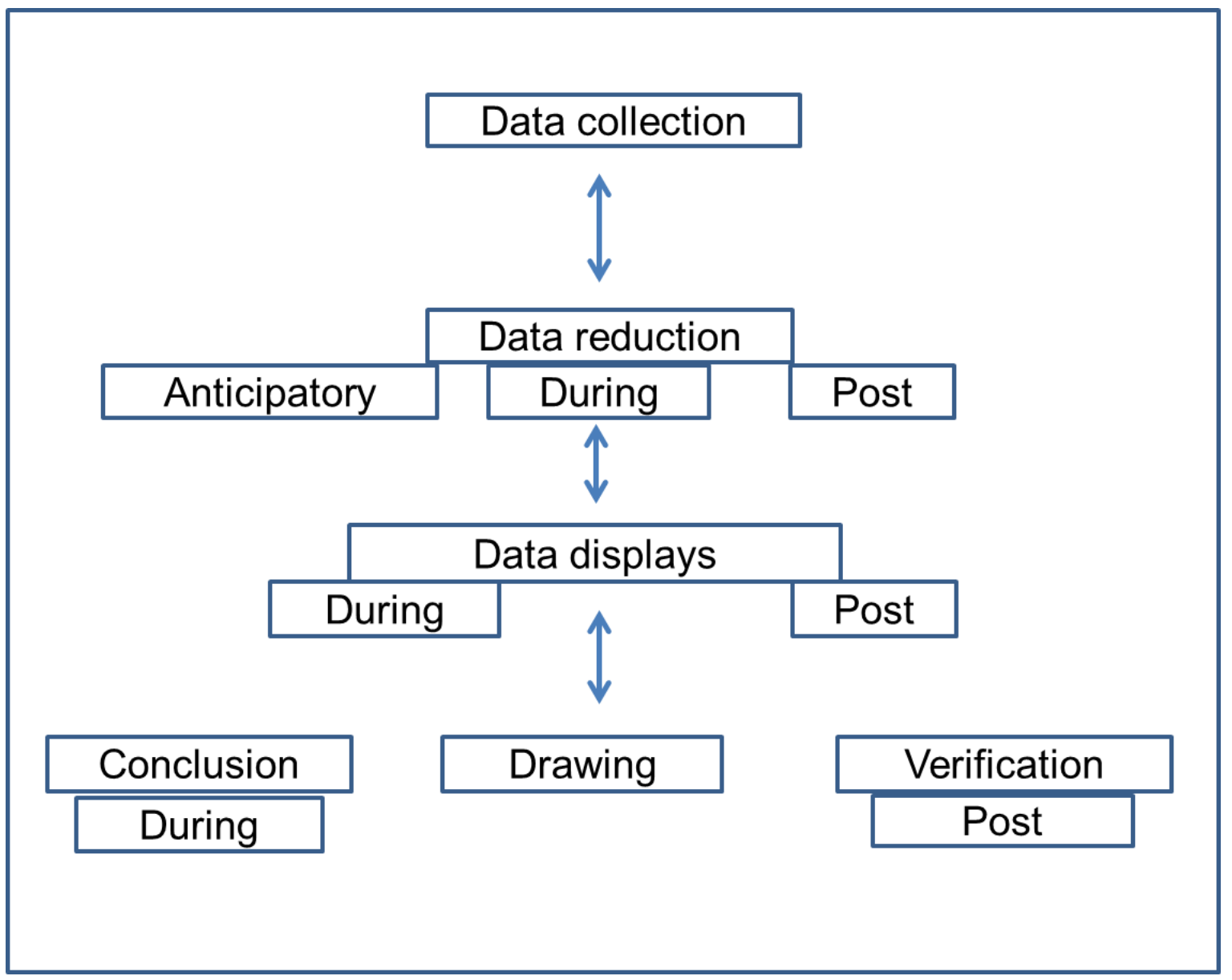

Figure 3.7: How data was analysed

Source: Adapted from Miles and Huberman, 1994

To reach data saturation I explored all the aspects of the phenomenon under study and use open-ended questions to collect data from farmers, government officials, traditional authorities, and non-governmental organisations. Data from different informants validated same ideas as I studied my notes and transcripts in the field. Theories and concepts developed were used as a tool to check for gaps in data collection and more data was collected and new themes were contextualised in the event of a gap at any junction. This continuous process of data processing, analysis, and verification (with participants) made this research work theoretically saturated with relevant and fully developed theories. 


\section{Chapter 4 - Dagbon and its Evolving Agricultural System}

"The only way to stop these fights is to burn all the compounds and food,[sic] I made a very thorough job of it yesterday . . I hate these fine men to kill each other when I am convinced that by burning their compounds fights would very soon stop." (District Chief, 1926).

"Forced labour was used in great quantities, to the detriment of agricultural development... 'our calls for carriers at all times of the year, as not alone does this practice deplete certain country sides at critical farming times but also the young men are inclined to leave the country on account of it" (Staniland, 1975: 46).

\section{Introduction}

Chapters 4 and 5 cover the same time trajectory but deal with slightly different subject matter. Chapter 4 presents the overall context of the agricultural reform and Chapter 5 delves into how the multiple government relationships with chiefs has reshaped the land tenure system in Ghana. This chapter will be framed by the notion of entangled history adopted from the works of Weiss (2004), where the interactions of different "social spaces" are studied to understand production, distribution and consumption patterns which overlap over time. In this chapter, the agricultural system in the Northern region will be presented as it evolves from the pre-colonial years to present day with an emphasis on changes through the interaction of different material and social cultures. The agricultural system in Africa has always been predominantly subsistence, even with the introduction of many technological packages to revolutionise this sector during colonial rule and later in the 1960's Green Revolution. Foras like the African Green Revolution Forum (AGRF) brought together all relevant stakeholders in September 2016 with the aim of cultivating discussions concerning the possibility of new agricultural policies and investments which will transform the African farming system.

AGRF aims at creating an industrialised agricultural system which can be achieved through a combination of information technologies, liberalised input market, financial investments and infrastructural development amongst other factors. Small-scale agricultural transformation can already be seen in the horticultural sector in countries like Kenya and Ethiopia and in the cereal sector in Nigeria and Senegal according to the African Development Bank (2016). 
This chapter will be divided into three sections. The first section will examine the history of the Dagomba people (who are part of the Mossi-Dagomba states and populate the study area), and how they settled in present day Northern Ghana. I will describe the socio-economic activities of these people and explain how these have shaped their current socio-political structure, with emphasis on the Dagbon dynasty. In the second section I will also explain how the agricultural activities of the Dagomba people have been shaped by the different land and agricultural policies enacted and carried out in pre-colonial, colonial and post-colonial times. This is meant to give the reader a glimpse as to why vegetable agriculture has become an integral economic activity of the Dagomba people. The third section will focus mainly on the effects of urbanisation on vegetable farming in the city of Tamale, which will compliment data discussed in Chapters 1,6 and 7. The agricultural activities of the Dagomba people from the pre-colonial era will be explained from interviews, focus group discussions and oral history collected by anthropologists and historians who first visited these people. Even though oral history is considered problematic due to its sources and credence, it gives a clear picture of the past sociopolitical relationship of people to farming (Tait, 1955).

In this chapterl will talk aboutchanges in crop production and livestock rearing alike, but this thesis focuses on dry season vegetable production, as already explained in Chapter 1 and later in Chapters 6 and 7. A summary will be made at the end of each section, as well as its relevance to the chapter and the thesis as a whole.

\subsection{Origin of the Dagbon kingdom}

The Dagomba people are part of the ethnically related Mossi-Dagomba states. These states are made up of the Dagomba, the Mamprusi, the Nanumba and the Mossi's from Ouagadougou, Yatenga and Fada N'Grumah (lliasu, 1971). According to Rattray (1932: 549), these states were founded by a "small band of strangers." These strangers migrated from the East or North East of Lake Chad into the lands South of the Niger Bend, which is known today as Nigeria. They were accustomed to the idea of chieftaincy, "as opposed to the politico-ritual organization of the acephalous peoples they encountered," which has no central organisation and relied on the earth priest and elders for guidance (lliasu, 1971: 95). The history of the Mole-Dagbani (Mossi-Dagomba) states has many variants originating from the different sources of oral history, with evidence consolidated by various authors who wrote on these states. This evidence constitutes the Mossi-centred evidence and the Mamprusi- Dagomba evidence. These different pieces of evidence have different historical starting points, but, most importantly, they all have the same endpoint. The Dagomba oral tradition is more accessible and visible due to the creation of the elaborate and efficient machinery of the state drummers "lunsi" (lunse) who are court historians and form the core of this machinery. 
In this chapter I will give an encompassing history of the Dagomba people that is mindful of the different written versions available. The history of the Dagomba people is wrapped in many mythical events dwelling on historical recollections (or memories) which define the people. Here the author explains how memories, constructed through mystical tales, are used by people to shape and reproduce their socio-political and economic status in the past and present. Their identities as 'Dagombas' are intertwined in these tales. The concept of 'memory in the making' or 'memoirs' best explains the importance of historical recollections in understanding people's socio-political structure (Hagberg, 2006). In Chapters 6 and 7 I will explain how farmers use historical recollections in the construction and reshaping of development discourses which suit their interest of maintaining access to land and water for their agricultural practice.

Lentz (2013) looks at historical recollections from the angle of contradictory versions of history. She argues that in most cases respondents did not agree on their versions of history in her study because each group had constructed different histories to legitimise their claims. She explained that most firstcomer narratives acted as oral land registries, where the storyteller version could be legitimised or not. I agree with Lentz that histories are not just stories told to foreign anthropologist; they are also stories used by people to explain who they are and to legitimise claims in resource disputes with other communities and clans. In this chapter I will make use of oral history, interviews, focus group discussions and secondary literature to explain the history and agricultural system of the Dagomba people from the colonial period to contemporary times.

The history of the Mossi-Dagomba States is traced from a man known as Tohazie the 'red hunter' who was the son of Tiyawumya (Iliasu, 1971). His father was from the family of King Shabarko in ancient Egypt. Tiyawumya was born in Massari and moved through Thungi to present day Morrocco. From Morrocco, he migrated to somewhere East of Lake Chad and finally to Zamfara at a place called 'Banza Bokwoi' North of Borgu where he presumably gave birth to Tohazie (Staniland, 1975). According to Tranakides (1953), these 'red people' were possibly the military aristocracy of the Mossi-Dagomba people.

According to oral tales and an interview with the great Lunsi in Choggu, I was told that Tohazie was a skilled hunter who is said to have rescued an ancient Malian town from a wild bull that blocked access to their only source of water. This Mali town would be 'Melle', Southeast of Fada N'Gurmah, and not the Mali empire of the West, the present-day Republic of Mali (Tamakloe, 1931). After Tohazie had killed the bull, he cut off the head of the animal and sent it to the king as proof of his act of bravery. To repay his kindness, he was asked by the king to choose any of his daughters for marriage. He selected Pay' Wobga, one of the princesses who was crippled. When the people in the community asked why he chose the crippled lady when he had many beautiful princesses to choose from, who were not crippled the hunter 
(Tohazie) said he liked her and her looks told him that he was going to produce an ethnic group which the whole world would know of due to its greatness, and the community concurred with him.

The Malian legend of Sadio records the bravery of Tohazie in the fights against his enemies under the service of the Malian king. Tohazie established himself amongst the Mande and Gur-speaking people south of the Niger as a successful warrior and leader till he moved to Biun in Grumah land where he died. Kpognambo, the son of Tohazie, married two wives, one of whom, Sohiyini, was the daughter of Abdul Rahamani, king of Grumah. Together they had a son called Gbewa who is "the great ancestor of the Mossi-Dagomba peoples" (Iliasu, 1971: 96). His other wife, daughter to the earth priest of Birum who Tohazie assassinated in order gain leadership, gave birth to Malgimsim, Nyelgili, and Namzisheli (Tsikata and Seini, 2004). In the story it is said that when Tohazie killed the earth priest he took the earth priest's clothes and wore them. This is mentioned in the history of Dagbon by lunsi Dakpem Lung naa. Presently in the Dagbon customs the king of Dagbon wears this same cloth when he is enskinned, but other authors like Imam (2015a) state that the cloth the new king is enkinned with belonged to the earth priest killed in the former Dagbon capital in Yiendi-Diari, known as Chare by the Konkombas, and not Bium.

The tentative dates for the emergence of the ancient Dagbon Kingdom consisting of the Dagomba, Mamprusi, and Nunumba, are around the $11^{\text {th }}$ and $12^{\text {th }}$ century from the Mossicentred evidence (Delafosse, 1912; Tauxier, 1912). According to Fage (1956) and lliasu (1971), the tentative dates for the emergence of the ancient Dagbon Kingdom are possibly faulty because they were calculated based on theoretically average reign lengths of the different rulers and this type of analysis has its limitations. The generally accepted time in which the Dagbon kingdom emerged is the $14^{\text {th }}$ century, as stated by Tamakloe (1931), Fage (1964) and Iliasu (1971).

Iliasu (1971) explains that after the death of Kpognambo (one of the sons of Tohazie), his remaining sons were in constant conflict over the succession to the throne. Even though Gbewa's fraction won the fight for succession, he decided to split and move with a large following to Sanga or Sana, south of Fada N'Grumah. He gradually conquered part of the Busansi and Kusasi territories and later moved his base of operation to Pusiga from Sanga. The territories under his control, according to the Mamprusi oral history, are said to have stretched from the White to the Black Volta. Gbewa's reign was one of peace. According to these accounts, his first child, Kachiogu, could not succeed him because she was a woman. He considered his first son, Zirili unfavorable due to his love for adventure. He appointed a different son named Kifogu as his heir, but Zirili killed him. In the Dagbon tradition presently, according to my interview with Sahini, a farmer at Sangani: 
A man does not pronounce to the hearing of others his heir. It is believed that if he does so, the heir will be killed by his enemies in or out of the family. Sometimes the heir is sent out to other relatives where he will be brought up and will only come back to take over his father's property at his death (Interview, 2014).

Gbewa, upon receiving the tragic news of Kifogu's murder, moved restlessly on his skin (refers to the seat of the King in the Northern Region) until the ground opened up and swallowed him and Zirili succeeded him. This statement is just meant to show the extent to which Gbewa loved his son Kifogu. This event led to conflicts as Zirili's succession was not supported by his siblings. This split of siblings is what resulted in the breakup of the ancient Dagbon kingdom and the creation of the Mamprusi kingdom by Tohagu, the Nanunba Kingdom by Mantambo and the modern Dagbon Kingdom by Sitobu. Their sister married at N'Grumah and established the Mossi Kingdom. This is to say the Dagomba's, the Nanumba's and the Mamprusi's are siblings and are cousins with the Mossi.

This narrative gives us a glimpse into the socio-political life of the Dagbon people, which is embedded in their origin. Their historical recollections are echoed by current writers like Imam (2015a) and Mahama (2003) who have painted them as warriors, skilled hunters, and great agriculturalists. They are organised in centralised states with a patriarchal system of inheritance where women are not included in the decision making of the state. The Dagbon people adopted the cultures of those they conquered, but maintained their class as royals in the socio-political structure as will be explained further in this chapter. Some earth priests still exist and perform rituals and sacrifices to the earth god on behalf of the people for a good and fruitful season. These are all elements which defined the functioning of the present day Dagbon kingdom.

\subsubsection{The birth of modern Dagbon}

According to Tamakloe (1931) one of the earliest writers on Dagbon, before Nyaysi and his father Sitobu came to Dagbon around 1416, there were already aborigines settling in this area. Rattray (1932: xii) confirms this assertion when he writes:

The majority of the tribes who inhabit the Northern Territories were, I am convinced, residents in or near the localities where we now find them, centuries before the ancestors of those names many of the divisions now bear had arrived in this part of Africa. Upon these more or less autochonous people with their primitive institutions ascended small bands of strangers within comparatively recent historical times. 
These aborigines were called the Dagbamba or the "Black Dagomba" (lliasu, 1971: 99). Tamakloe (1931) traced the ancestors of the Dagbamba people to the descendants of Ad, during the time of Prophet Noah in the Arabian lands. It is said by Imam (2015a: 128-29) that after:

The confusion of tongues the tribe of $\mathrm{Ad}$, the son of $\mathrm{Uz}$, the son of Aram, son of Shem, son of Noah settled in the Province of Hadramaut where their posterity greatly multiplied. This tribe continued to worship God but in process of time they fell from the worship of true God into idolatry. God seeing this sent them the prophet Heber to preach and reclaim them. But when they refused to acknowledge his mission, God sent a hot and suffocating wind, which blew seven nights and eight days together and which entering into their nostrils passed through their bodies and destroyed them all and saved the very few who had believed in Heber. This tribe we learned were of prodigious stature, the tallest of them being said to be a hundred cubits or a hundred and fifty feet in heights and the least of them sixty cubits or ninety feet. This tribe, it is said, wandered towards the East and the West, settling in inhibited countries, till they arrived in the country which is today called "Dagbon" and their progeny were called Dagbamba.

In line with an article found at the Dagbon Website ${ }^{16}$, the name Dagbon was coined from the animal skin on which the Ad priest sat. This skin was referred to as 'Ada Gbon' which has been corrupted to Dagbon. The Dagbon area was consolidated by Sitobu, father of Nyaysi, who is known to have killed almost all the earth priests and pushed back the Kokomba's from Yiendi Diari in the then Western Dagomba (Froelich, 1954; Tait, 1963). The Dagombas also fought the Gonjas to secure the trade routes in Eastern Dagomba from Kumasi to Jenné but did not kill many earth priest in this area (Staniland, 1975). This is the reason why many earth priests exist in the Upper East and West Regions in Northern Ghana but not in the Northern Region where Situbu became the king (Ya naa). He replaced the dead earth priests with his younger brothers as divisional chiefs - Biemone became Karaga Na, Biyumkomba became Mion-Lana, Bojyeligu became Sunson- $\mathrm{Na}$, and his other two brothers became Kuga-naa (elder of the king) and baga (soothsayer for the king). They were conferred with the powers to rule over the people. The chiefs on their own employed earth priests to take care of

${ }^{16}$ http://dagbonweb.com/history.php?article ID=185\&sid=2, accessed 22.02.2016 
rituals and sacrifices to the gods, while the few earth priest who were not killed continued in their spiritual function but were controlled by the chiefs. Any Ya naa had to come from - Karaga, Mion or Savelugu. They had to be a son of a former Ya naa, and any individual in pursuit of this position, cannot get a greater position than his father before him (Staniland, 1975). All these rules were meant to reduce the number of eligible candidates for succession so as to reduce conflict, as reflected in Goody's (1978: 30-31) study on the Gonja's when he says:

In agnatic systems ... the effects of polygynous marriage can mean a rapid growth of the dynasty over a very few generations ... Such growth complicates the process of selection, because the larger the number of eligibles the more difficult they are to handle. Where the support of such a large dynasty is not required, one solution is to lop off the unwanted branches ... Homicide apart, the dynasty can only be cut down in size by shedding whole segments (i.e. lineages) whose claim to the throne has now become distant.

Two important non-royal chiefdoms were established as a gift to the commoners. They were the Tolon and Kumbungu chiefdoms. The Tolon naa is the traditional head of the King's army and the Kumbugu naa the head of archery. These are important socio-political structures which still exist in the Dagbon Dynasty, and on which the Dagbon dynasty was built. The Ya Naa became the commander of the Dagomba army and highest administrator of the state. He was also the lineage head of the dynasty, head of the royal patrician, and a figure surrounded by rituals of avoidance and deference (Staniland, 1975). An excavation in Yiendi-Diari revealed what seems to be a caravanserai, possible the merchant quarters of soninké wangara. This shows that the Dagombas were active participants in trading and enjoyed benefits of being along the trading routes. The trade traffic volume was increasing along the Salaga trade routes close to Daboya, and the Dagombas did not want to miss out on this opportunity (Talton, 2010). According to Bowdich (1819: 178):

Yahndi is described to be beyond comparison larger than Coomassie, the houses much better built and ornamented. The Ashantees who had visited it told me they frequently lost themselves in the streets .... The markets of Yahndi are described as animated scenes of commerce, constantly crowded with merchants from almost all the countries of the interior. Horses and cattle abound, and immense flocks are possessed even by the poorer class. 
From Bowdich's description, we see the benefits of trade in Yiendi and the reason why the Dagombas pushed the Gonjas to secure the trade routes. The Dagbon kingdom is presently the largest in the Northern Region of Ghana and accounts for more than half of the total population of the Region (Tsikata and Seini, 2004).

\subsection{Changing agricultural systems in the Northern Region}

Blench and Dendo (2007) estimate the surface area of the Northern Region to be $70,384 \mathrm{sq} . \mathrm{km}$. It is the largest region in Ghana, found in the Northern parts as seen in Figure 4.1. It comprises about $41 \%$ of the total land area in Ghana and has its headquarters the Tamale Metropolis. Its population density is noted to be the lowest in the country.

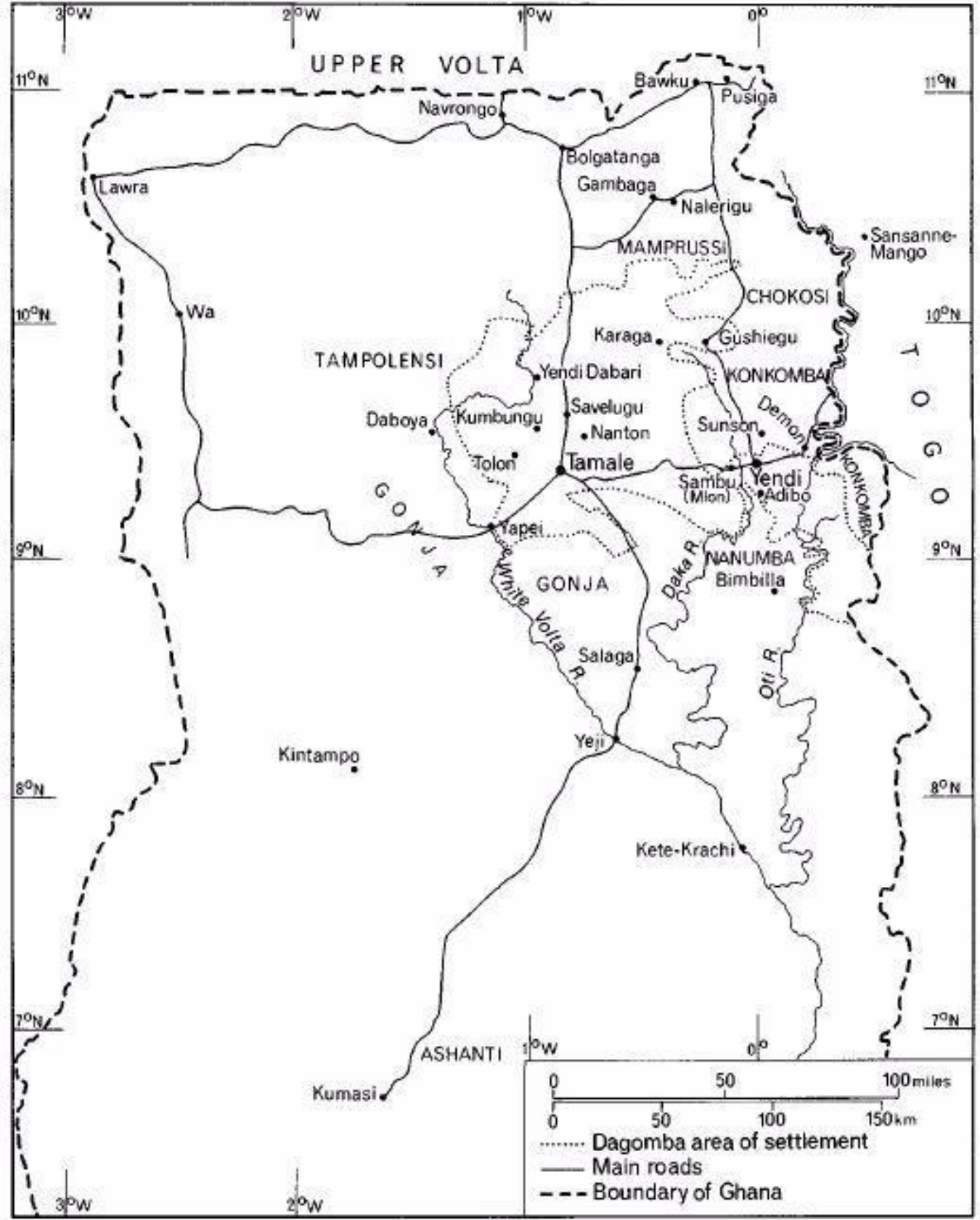


Figure 4.1: Map of Northern Ghana in 1965

Source: Staniland, 1975

Rain-fed agriculture is predominant in this region as opposed to irrigated farming which, though present in the country, takes place in less than $2 \%$ of the total cultivated area in Ghana (Blench and Dendo, 2007; Namara et al., 2011). The main economic activity of the Dagomba's is agriculture, which employs more than $70 \%$ of the active population (Ghana Statistical Service, 2013). Most importantly about $90.5 \%$ of households in the Northern region practice crop farming compared to other forms of agriculture (Ghana Statistical Service, 2013).

Interviews with one of my key informants in the field revealed that the Dagbon people have always relied on their farming skills as a source of income to provide and sustain their families. This informant stated that when the colonial administrators came and settled in Tamale as their headquarters, few Dagomba's were interested in administrative jobs like clerks, teachers because a man was defined according to his capacity to provide food for his family from his field, and white collar jobs were considered "activities of the weak". Informal conversations coupled with oral tales confirm that agriculture is an ancient activity which constitutes the backbone of the Dagomba identity. In the next sections, we will examine how the agricultural system in the Northern region has evolved over time. I also examine how different agricultural policies have contributed to the present agricultural system in this region. Changes in the agricultural activities of the Dagomba people will be considered at different time scales from pre-colonial times to the present date.

\subsubsection{Pre-colonial era}

In pre-colonial times, agricultural activities of the Dagomba's were captured by historians and anthropologist through tales and participant observation of the people who visited the Gold Coast and the Togoland. Cardinall and Tamakloe (1931) argue that, even though most traditional tales and history in Africa are regarded as superstition, they are absolutely believed to be true by the people who live it daily and to whom it is considered perfectly natural. Cardinall and Tamakloe place this this assertion in opposition to tales in European peasant societies, which are half-believed and are not assumed to be natural occurrences. Talton (2010) also emphasises the importance of historical recollections in defining the customs and traditions of people, their socio-political structure and how they construct their identity and access to different resources. Through tales on human interactions with the gods, we see a clear picture of the type of agricultural system that existed before colonialism (Cardinall and Tamakloe, 1931). This is explained in the tale of Edubiaku the Wise Child, which describes how man received seeds as a gift from the gods to plant far afield and, later, around the living abode. 
The idea of farming far away from the living quarters or the compound is corroborated by Blench and Dendo (2007) when they talk about the practice of bush farming in the Northern parts of Ghana. He explains that many fields were cultivated far from the living abode - about 4 to $10 \mathrm{~km}$, a situation which we still find today in the Northern region. From the different tales written in Cardinall and Tamakloe (1931), Te author decipher that due to the destruction of crops far from the compound by animals, the guard of the gods advised humans to sow their seeds close to their compounds. This idea is referred to as backyard farms or compound farms which are considered an ancient activity that existed all over the world and is practiced by Northerners today as explained by Niñez (1984)

As stated by Kranjac-Berisavljevic and Gandaa (2004), about $75 \%$ of farmers in the North cultivate yams; this region constitutes the 'yam zone' which runs from Cameroon to Ivory Coast supplying about $90 \%$ of the world's yams each year, which is about 33.7 million tonnes (Mclntyre, 2009). Yam farming is not just an economic activity, it is embedded in the culture and traditions of the people. During communal farming yam seedlings are exchanged between families and used as a ritual to appease the gods. These seedlings are believed to possess blessings from the gods and manifest in high yields (Kranjac-Berisavljevic and Gandaa, 2004). Apart from yams, cereals like sorghum, millet and guinea corn are also cultivated in this region alongside livestock rearing (McIntyre, 2009).

These activities can be seen in the stories narrated by Cardinall and Tamakloe (1931) about the cob of maize and a hundred slaves. In this tale, a god visited the Dagomba's and lost his son during his sojourn with them. To sympathise with him, they offered him abundant maize as compensation. This tale shows the hospitality of the Dagomba people, showcasing one of their stpale crops. This story shows the economic activities already practiced at that time, one of crop cultivation. These agricultural activities were mainly for subsistence, where surpluses were sold in the regional and local markets, especially along the Salaga slave market route, in order to get other needed goods (Sutton, 1989).

The main ways of cultivating land in the pre-colonial era were through bush fallowing and shifting cultivation, as explained by Blench (1999). He stated that bush farms were cultivated for three to four years and when it showed signs of low productivity this land was left to fallow and another area was chosen for farming. In order to access new lands for farming one gave a token to the chief or the tindana of the village. This token often came in the form of giving a kola nut, after which a ritual is performed to bless the land. Then the new owner gets 'use right' to the land, which he can pass on from generation to another.

The Linguist - the spokesman of the Zagyuri chief - informed me during an interview that, during the pre-colonial times, when a person requested a piece of land for farming, markings on trees or physical objects like stones were used as boundary markers. This was a way to make the land legible and easy to manage by the chief. It was also an act of grounding 
claims, as explained in Chapter 2. Because land is not moveable and the rights non-tranfeable for non-locals, they were lands for farming and housing with use rights. This meant when a stranger decides to leave an area of land acquired traditionally, he forfeits all investments made on the land. He is not authorised to sell the land or the investments on it because the land was not sold to him. In the case of indigenes, the use rights on the land can be passed on from one generation to another, or if the indigene wants to leave the area he can give the land to another indigene or relative after the chief has been informed and agrees to this new arrangement.

Land access was administered by the males in the households and women could get access to land only through them. This solidified the status of men as the decision makers in the community and society as a whole, a social norm which still exists today in Tamale. Rituals and libations were poured on land for cleansing, an activity performed by the traditional institutions, which are constituted of mostly men. These rituals and sacrifices transformed land into a spiritual being through which one communicates with his ancestors. This is one of the reasons why lands are allocated and not sold in this region. This tradition is now dying out as lands are now being sold by chiefs for personal gain, especially as the value of land have increased due to urbanisation (Yaro, 2010).

In one of my many focus group discussions at Sangani, farmers informed me that this site is considered a sacred shrine by the clan. I was told that their ancestors have been performing rituals and sacrifices to their gods here since before the coming of the Europeans. There is a natural spring on this land and a big kapok tree (Ceiba pentandra) where these rituals take place. An animal is usually killed by the spring then it is burnt, prepared and eaten under the kapok tree, as no sacrificial meat could leave the sacred grounds. When the rains do not come as expected, a special ancestral stone will be taken out of the spring amidst animal sacrifices, and the gods will respond by sending rain so the ancestral stone can return to the water where it belongs.

These rituals and sacrifices were done by men, who are part of the priestly and chieftaincy institutions. Here the reader will be made to understand how tradition in the form of sacrifices throughout the year "promote agriculture and the harmony of the local group" this ritual strengthens the "well-being of the community and reaffirm the solidarity of lineages." (Blench, 1999). This traditional activity of performing rituals also became an important element in promoting livestock rearing, as animals were always needed for sacrifices (ibid: 10). In chapter 6, I will further explain the importance of religion in accessing and maintaining rights over resources for vegetable farming.

Women were ascribed certain agricultural and social roles in the household and community both then and now, as argued by Nchanji and Bellwood-Howard (2016a). A woman was expected to cultivate vegetables and legumes at the fringes of the family's bush farm. 
This was a traditional responsibility in relation to household meals where the woman "provide the ingredients for preparing the soup or stew which goes with food prepared from grains supplied by the husband" (Benneh, 1968: 32). From interviews, I gathered that a woman who could not provide soup for her household was labeled useless and sometimes called a witch. This was because food provisioning responsibilities were taken seriously in the society or community, and one's failure then was considered an act of wickedness.

This complementary division of labour, according to Benneh (1968), might have originated according to Goody and Buckley's (1973: 108) explanation that, during this time, hunters constituted one of the most important subgroups in this society and they contributed significantly to the diet of villagers. Therefore:

\begin{abstract}
If at the hunting stage women were the ones who collected vegetable produce, they would tend to be the ones concerned with cultivating the domestic varieties of these plants; just as men who had formerly been concerned with hunting wild animals would tend to take over the husbandry of domestic livestock.
\end{abstract}

Musah (2013) and Tengan (2000) detail the importance of the traditional maternity leave women took during the birth of the first and second child in their natal homes in relation to their traditional provisioning roles. During this period, women were expected to stay with their parents until their children started walking. During this time, they could work on farms belonging to their parents or natal family. The new mother was expected to accumulate her 'bride wealth' which she will later take to their husband household, to continue life officially as the 'cooking wife.' This accumulated wealth exclusively belonged to the woman. This wealth was in the form of money or material objects of value that the woman had been given or had bought. Men created control mechanisms to regulate the wealth of women through the use of labels such as 'witches.' For example, if a woman shows more economic prowess than her husband and acquires a piece of land or building without his consent she may be labeled a witch by her husband. When this is done, the society and her family abandon the 'witch' to her own devices and have nothing to do with her

A woman's identity is constructed amongst the Dagomba's as secondary - she is expected to be humble and respectful to her husband and do all to please him. The woman becomes a caregiver expected to clean, cook and care for their children and her husband. Women's decisions need to be vetoed by their husbands before any action is taken, making the men the decision makers of the home. Expectations for how a woman should behave are norms created and moderated by men who constitute the ruling class and are mostly involved 
in constructing and reshaping norms and values of the society (Nchanji and Bellwood-Howard, 2016a).

Focus group discussions with farmers revealed that crop farming was done mainly through human physical labour, from clearing the land, sowing and harvesting. Marketing was mainly done by women or children, with goods carried on the heads and sold in the villages or in the markets depending on the goods for sale. Among the Dagomba people clearing the fields, sowing, harvesting and marketing are activities divided amongst men and women. Women are predominantly marketers while clearing the fields, sowing, and harvesting are done by both men and women. The "traditional food farming in Ghana is family labour inclined - where members of the family operate as a production unit to cultivate small scattered fields with simple like tools - cutlasses and hoes - to, cater mainly for their food needs" (Benneh, 1968: 28; Dickson, 1969). The family in the Dagomba context from interviews and participant observation in the field - includes everyone that makes up a compound.

A compound, as depicted in Figure 4.2, is usually made up of the household head, his wives and children, his brothers, their wives and children and maybe his parents. Everyone in the compound is considered a family as they usually eat from the same pot and the women each have a day to prepare food for the whole compound. The main entrance is usually meant to entertain guest. The household head's hut and that of his last wife are close to entrance of his redidence. The rest of the family is found in the buildings in the middle. Food and livestock is stored close to the entrance on the left side of the compound. The power dynamics are clear with the household head building taking a central stage to all activities in the compound. The size of the farm usually reflects the availability of family labour. The Dagomba families are generally large and range from 6-20 people. The main crops grown were and are yams (Dioscorea alata), guinea-corn (Sorghum bicolor), millet (Pennisetum glaucum), legumes (Fabaceae leguminosae) and vegetables. Women cultivate legumes and vegetables at the edge of the main fields, as stated above, while the cereal staples are cultivated by men in the center of the farm. Intercropping and mono-cropping were both practiced by farmers. Cereals and rice were usually planted on the same land, and never rotated with other crops. Legumes, cereals, and vegetables were mostly intercropped in the compound or backyard farms.

Dickson (1969: 77) details the farming process: "preparation of land for sowing began with burning the bush, after which the charred bush was slashed with cutlasses and thrown, together with tree trunk..." The clearing of the fields, building ridges and weeding were done mainly by men, and the main task of the women are sowing and harvesting of crops to preserve in the household barn, an activity which they sometimes shared with the men (Benneh, 1968). When crops get into the barn, especially cereals, the men are in charge of giving it out to their different wives or sister-in-laws assigned to cook food. A woman cannot help herself to cereals in the barn without permission from the household head. 


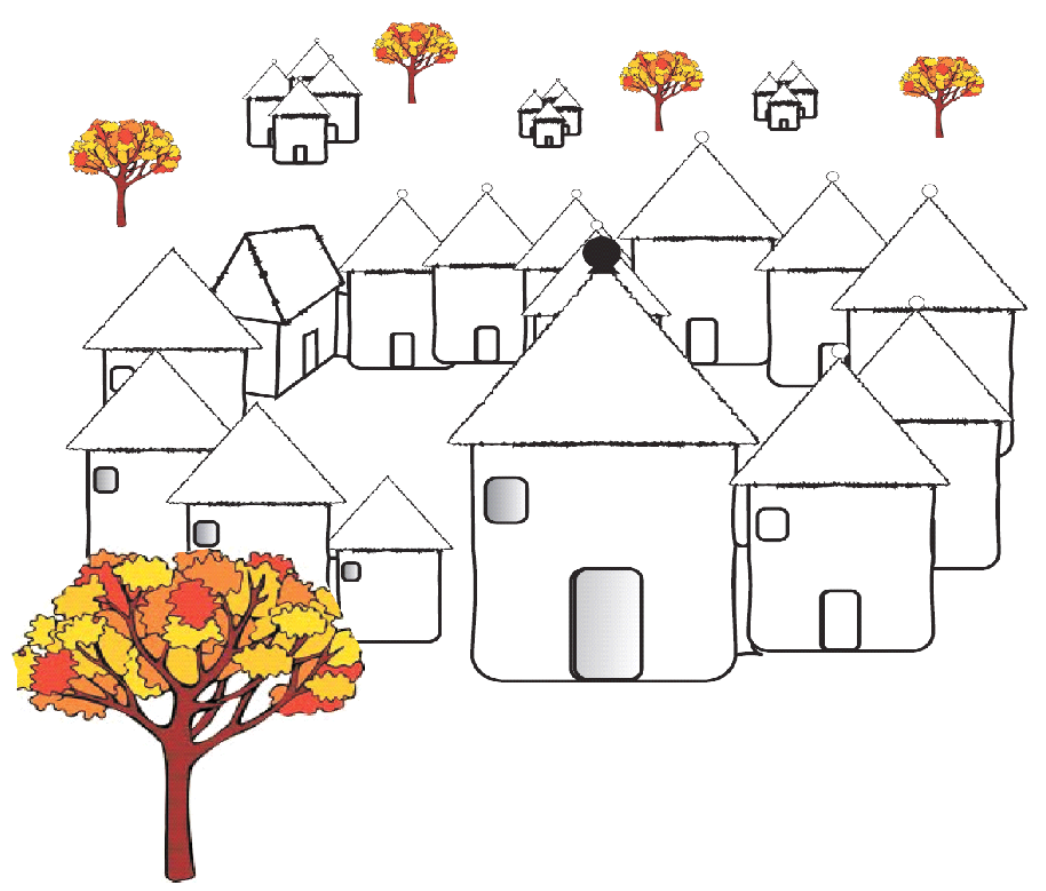

Figure 4.2: Drawing of a Dagomba compound with the different traditional houses Source: Author's construct, with her assistant Mr. Baako, 2014

Other forms of labour also existed apart from family labour, such as communal labour. Communal labour usually involves people working communally without monetary rewards on the farms of another community member. This communal form of labour was usually organised amongst groups of families, friends or lineages. The host farmer was expected to provide food and drinks like pito (which is made of fermented millet and brewed for some hours) for all during the period they worked in his field. This system of farming was rotatory and was sometimes extended to the sick or very old in the community, who at one time was part of this scheme (Benneh, 1968; Dickson, 1969).

Chiefs also relied on community labour for their large farms (Benneh, 1968). This is seen clearly in Fortes and Fortes's (1936) ethnographic data, which stated that chiefs and headmen had food even in hard times due to community labour. In Weiss (2004) the diaries of District Commissioners revealed that locust invasion destruction was less on the farms of the chiefs than the villagers as the chiefs mandated their subjects to kill locust on their farms first before theirs. Chiefs, as the heads of their communities, had considerable power over decisions that affected the socio-economic and political structure of the communities. There was a defined set of rules in matters of tributes from the people to their chiefs, giving the chieftaincy institution prestige in the communities. For example, a prescribed quantity of yams, 
maize, and other foodstuffs was provided by the head of a compound to the local chief to safeguard use rights over land for farming and maintain a cordial relationship that permits for continual access to land. In the case where land was leased for housing, the local chief will divide the token he took between him, the district chief and paramount chief. In this way, the Dagombas recognised the right of their chiefs as caretakers of land on behalf of the community, who, as allodial owners, gave out usufruct rights to those who needed land to farm (Staniland, 1975).

In the pre-colonial era, the hierarchy of subspontaneous tree species was probably the African locust/dawadawa (Parkia biglobosa), shea ( Vitellaria paradoxa), kapok (Ceiba pentandra) and the neem tree (Azadirachta indica). The fruits or seeds of all these trees were considered to be of great value and their collection and processing the subject of some competition (Blench, 1999). These trees were relied on for different purposes; as a food spice, cooking oil, bathing soap, stuffing for pillows, clothes and cream for the body. These four important economic trees could be accessed by women only through the men in their lineages (Nchanji and Bellwood-Howard, 2016a). The dawadawa was owned by the sub chiefs, so permission needed to be obtained by all from the sub chiefs before it could be accessed as already mentioned in Chapter 1. Blench (1999: 4) supported this assertion when he said that "in a few areas, major trees, such as dawadawa, belong not to the farmer but to the chief who has the right to harvest them and give a portion to the farmer."

The processing of dawadawa and shea were mainly in the hands of the women. It was mainly consumed in the household, and the surpluses sold for the purchase of other household basic needs. Shea nuts were also processed and used as candles (Musah, 2013). According to Wardell and Fold (2013), the shea butter trade existed long before colonialism in West Africa. Sutton's (1981: 52) description of goods traded at the regional markets during the pre-colonial era states that "the amount of yams, cattle and shea butter passing south was directly related to the amount of salt going to north" through the trading links between the Sahelian kingdoms in the North and the Ashante kingdoms.

Apart from crop farming, the Dagombas also reared livestock for many reasons; as sacrifices to the gods in demand for a request, for annual rites to appease the earth god and for payment in exchange for farming services. Surpluses were usually sold and the money gained from sales was used to acquire other household needs. During the rainy season, animals were generally enclosed, to avoid crop destruction as agriculture was mainly rain-fed. Their feeding and care were primarily in the hands of women and children. During the dry season, animals are allowed out of the pens to roam and feed, this practice presently has led to many farmer-herder disputes, which I will discuss briefly later in this thesis. At this time ploughs were unknown, and animals were not used for farm work nor integrated into the farming economy (Dickson, 1969). 
Fynn (1971), in explaining events of the Ashante's invasion of the Northern territories in the mid- $16^{\text {th }}$ century by Opoku Ware (the grand-nephew of Osei Tutu), listed the weaponry used by the Dagomba cavalry as traditional, consisting of lances, spears, and sabers, while Bowdich (1819) mentions that other weapons used included bows and arrows, javelin and clubs. These traditional weapons are labeled as one of the reasons why the Ashante defeated the Dagombas because they had more sophisticated and modern weapons, such as muskets. As a result of the defeat of the Dagombas, they became a vassal state of the Ashante's according to Staniland (1975), but Bowdich (1819) argues that the Dagomba acceptance of defeat was an intelligent way of maintaining their trade links, which gave them access to taxes from goods sold on the market and not as a result of the use of traditional weapons. The defeat of the Dagomba cost them a yearly tax of slaves, cattle, sheep and cloth to the Ashantehene (King of the Ashante people). This invasion is also regarded as a strategy by the Ashante for securing labour for their gold mines and benefitting from the market activities in the North at the time.

It is evident from the discussion above that agriculture was mainly rain-fed and the crops grown were mainly cereals, legumes, vegetables and tubers for subsistence. Shifting cultivation and bush fallowing was common, and the farms were cultivated with rudimental tools like hoes and cutlasses. Here the reader sees how technology shapes the agricultural system or vice versa. Slash and burn farming was one of the main means of preparing land for sowing, a practice which is still being carried out today due to historical recollections of past farm experiences. Labour was produced mainly by the family, and the male household head usually made all farm-related decisions. Women's subsistence activities relied on the decisions made by men on how to gain and maintain access to different resources like land, forest or trees. Here one can see clearly how the identity of women are being constructed by male dominated institutions, who believe women should be subject to men and controlled in all they do. These constructions have structured the agricultural activities expected of men and women and greatly influence the agricultural system prevalent in Tamale. In addition, 'tradition' is being used by men to control women's access to resources for farming, that is, their productive and reproductive roles are dictated by tradition which has been constructed and reshaped by men as explained in Nchanji and Bellwood-Howard (2016a).

Even though land was considered abundant and accessed simply through a token given to the chief or tindana, the notion of land abundance in Africa is being contested by Lentz (2013), who states that land was never abundant, and that it has always been contested by different actors as they struggle to gain and maintain control over land. She explained that some actors had used different strategies, such as the first comer's concept, while others used tradition and power relations to legalise their claims over resources. Shifts in power relations over time and space between the chiefs and tindana have shaped resource access, as lands 
were now accessed mostly through chiefs and not tindanas, who were stripped of their sociopolitical power and left only with spiritual powers over land purification and rituals. A different scenario is found in the Upper East, and Upper West regions were the tindana still has the same socio-political power as the chief and are in charge of land administration and management.

Livestock was kept as a secondary activity mainly for subsistence and sacrifices. Livestock keeping was under the control of the men with women and children participating only in feedings the animals during the rainy season when the animals are not allowed to stray and destroyed crops. The society at this time was rudimentary and agrarian, with chiefs usurping the powers of the tindanas over resource management while the few tindanas whose lives were spared were restricted only to rituals and sacrifices. The next section discusses agricultural changes under colonial rule to see if it is different from pre-colonial times and how resources were accessed for farming. The section will examine changes in agricultural technology, labour relations and power relations in connection with resource access and control.

\subsubsection{Colonial era}

The scramble for territories in the hinterland of the Gold Coast was between the French, British and Germans. The Germans had made contacts with chiefs in Savelugu, Yendi, Salaga, Gambaga, Karaga and Nanton, who accepted German protection, according to Staniland (1975). This act by the Germans alarmed the British, who had their eyes on Salaga, one of the main trading routes in the North. They needed this area to be able to secure their commercial interest from the French. In 1899, after the Germans defeated the Dagomba at Aido and later destroyed Yendi. Britain and Germany decided to amicably come together and sign the AngloGerman treaty on $14^{\text {th }}$ November 1935 , which partitioned the Dagomba area between these two countries, as seen in Figure 4.3. The Eastern part of Dagomba was controlled by the Germans and the Western section by the British. After the First World War, when Germany was defeated, the British took over the Dagomba area that was previously under German control (Owusu-Ansah, 2014). 


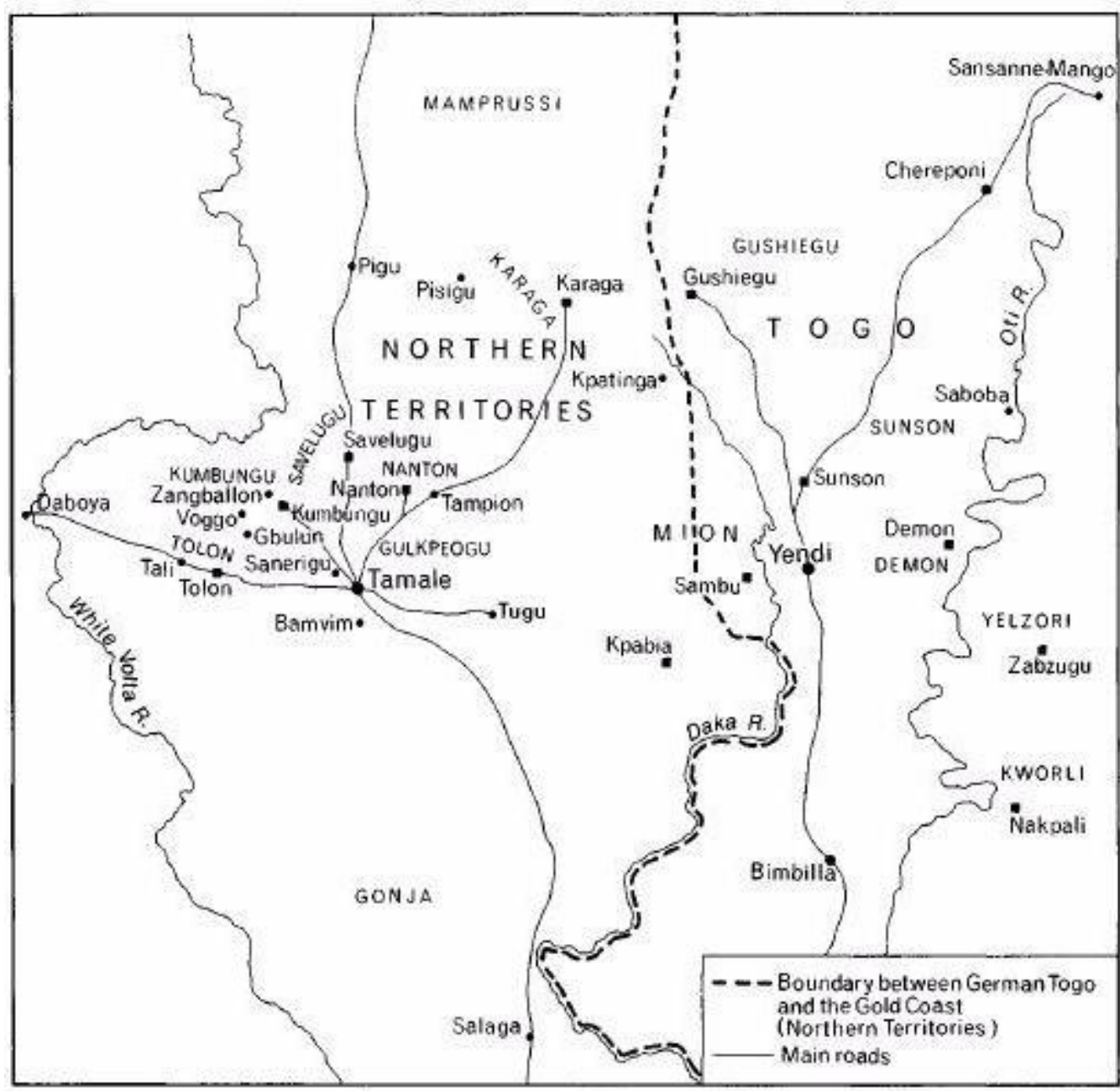

Figure 4.3: The partition of the Dagomba area

Source: Staniland, 1975

The Northern territories (present-day Northern Ghana), as seen in Figure 4.4, officially became a part of the British protectorate in 1902 after the defeat of the Germans. Sutton (1989) describes the delayed acquisition of the Northern territories to a British Gold coast colony as an afterthought, or so they seemed to be during British colonial rule. After the annexation of the Northern territories to the Gold Coast explorations were set in motion to find out the economic and political potential of this region to the Crown. George Ekem Ferguson, a Fante geologist, was employed by the Gold Coast government to make British annexation of the Northern territories legible. 


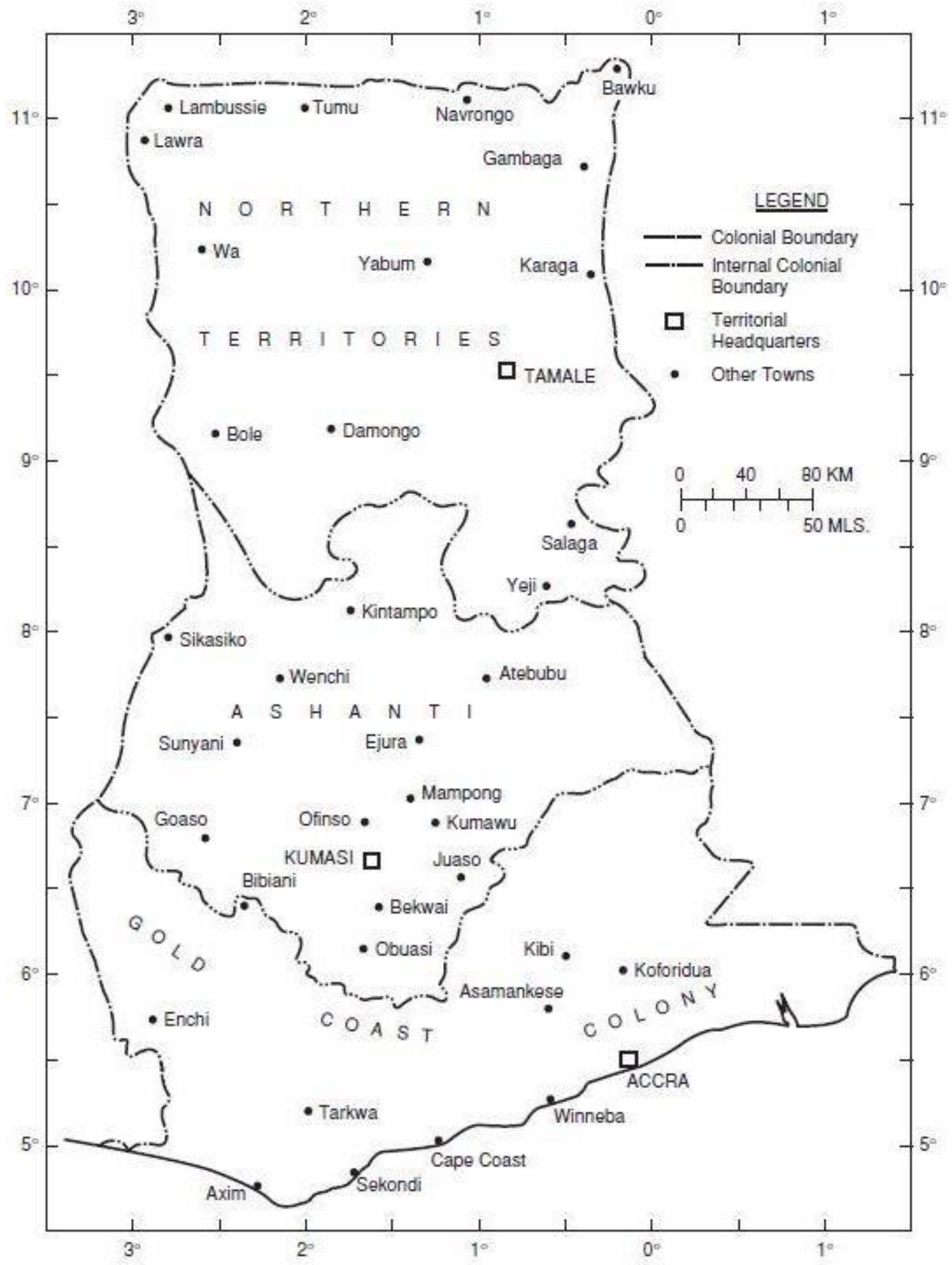

Figure 4.4: Gold coast, 1907, showing the Northern Territories

Source: Bening, 1999

Ferguson reported that some resources such as gold and ivory could be found in this region, but that the region's greatest potential laid in agriculture, "shea nut trees [sic] was widespread, rice and millet grew well in the plains, and the development of cotton, tobacco, and indigo" (Sutton, 1989: 638). Caravan trading was flourishing at this time but more in the 
hands of outsiders like the Hausa, Fulani from further North and the Mossi from further South. The people of the Northern territories mostly sold their surpluses to the caravans and people transporting shea butter and yams going South in the Volta salt canoes, but mainly got their income from the extraction of tolls and market taxes from traders along this trading route (Sutton, 1989).

The Northern territories were meant, like all other colonies, to provide raw materials for the European economy. The colony was expected to generate money to be used for running administrative cost and development projects (Blench, 1999). Revenue collected by the colonial administrators derived from the caravan tolls and tax amounted to about $£ 7000$ $£ 15,852$ yearly in 1907 (Sutton, 1989). The goods taxed were usually livestock brought from the French colonies in the North, kola nut which came from Ashante, salt from Ada at the mouth of the Volta and a few manufactured goods from Togo and the colony. In 1908 with the abolition of the caravan tolls the revenue of the administration of the Northern territories dwindled to about $£ 2000$. The administrators had to rely on revenue from the sales of yam, shea butter, dawadawa and cotton, which was not sufficient for the investment needed to improve sectors like transport, health, and education.

Staples constitute the backbone of the food economy of the Northern region, according to Fortes and Fortes (1936) and Shaffer (2015). They constitute the principle starchy foods relied upon in the households and that are eaten with vegetable soup. These staple foods are generally provided by the men while the women provide the vegetable soup to be consumed with it. Staples are of particular importance during the 'hunger months,' that is, during the time of hoeing, planting, and weeding (April-June). This concept of 'hunger month' is a phenomenon which is still present today in the Northern region (Apusigah, 2009). The Fortes monthly compilation of agricultural activities depicts clearly the hunger months or season in their account:

April: Food stores very low in average households and being rationed. Many households dependent upon supplementary sources of supply. Ample food supplies in market and many buying grain. Wild fruits ... being consumed to stave off hunger.

May: Food stores deplenished and severe rationing. 'Hunger' commences. Poorer households suffer two or three days' hunger a week, living on vegetable soup, ground-nuts and wild fruits.

June: Peak of 'hunger' reached. Granaries empty among poorer households... grain scarce and dear... Small groups of children wander about hungry, feeding on wild fruits and small animals ...people 
are staunching their hunger by cutting the ripe or half ripe heads of early millet which they roast ...

July: Wild fruit still eaten and hunger prevalent in late-planting areas ..." (Fortes and Fortes, 1936: 253-56).

Locusts are known symbolically as the scourge of the earth in religious circles. For example, God punished the Egyptians with a plague of locust that ravished the land of all its harvest in Exodus 10: 1-18. However, locusts are also delicacies amongst other societies (Anankware et al., 2015; Bequart, 1921). In West Africa there exist two different locust species which have been recorded, the African migratory locust (locusta migratoria miratorioides) and the desert locust (schistocerca gregaria), with main breeding areas in the marshes of the central delta of the Niger River, Lake Chad area and the Sahara Desert respectively. These locusts are prone to ravaging cereals like bulrush millet (pennisetum typhoideum), guinea-corn (sorghum vulgare) and millet (pennisetum spicatum) which are the main staple food for people in this guinea savannah zone.

Consequently, cereal producing communities were hard hit if the locust came when the crops were germinating or during the harvest (Weiss, 2004). Reports from 1910 to 1927 from archival material consulted by Weiss showed that trees also suffered from locust infestations even though the damage was minimal compared to cereals. Fruits trees were defoliated in the Tamale agricultural station and shea trees destroyed in Kusasi. The worst plagues of the migratory locust started in 1929 and continued for 10 years. This plagues caused extensive damage to the staple crops. Animals were sold to buy food, and large-scale emigration to the South was noted in some divisions like Lawra-Tuma. The chiefs solicited the help of the colonial government to get food from the South as hunger became widespread. The only sources of food available were tubers, such as yams and cassava, and also rice which the locusts did not destroy.

In addition, information collected from informal diaries of the different District Commissioners from Lawra and Bole paints a vivid image of these locust infestations. Some visual description of the infestations is; "Bole town was hidden in a red fog covering all the ground so it could not be seen" or according to Whittal "the swarm was enormous, 12 to 15 miles wide; it took six hours for the swarm to pass by and go out of sight" (Weiss, 2004: 11,14). Some reports of destructions of cereal farms in Lawra-Tuma district area is tabulated in Table 4.1 below. 
Table 4.1: Cereal farms destroyed by locust invasion in 1929

\begin{tabular}{|ll|l|l|l|}
\hline Data source & Date & Divisions & $\begin{array}{l}\text { Farms de- } \\
\text { stroyed }\end{array}$ \\
\hline $\begin{array}{l}\text { Informal Diary } \\
\text { Lawra }\end{array}$ & 16.11 .1929 & Sabule and Karui & 32 \\
\hline $\begin{array}{l}\text { Informal } \\
\text { Lawra }\end{array}$ & Diary & 28.11 .1929 & Sabule and Karui & 82 \\
\hline $\begin{array}{l}\text { Informal Diary } \\
\text { Lawra }\end{array}$ & 19.11 .1929 & Zini & 47 \\
\hline $\begin{array}{l}\text { Informal Diary } \\
\text { Lawra }\end{array}$ & 19.11 .1929 & Lambussie & 43 \\
\hline $\begin{array}{l}\text { Informal Diary } \\
\text { Lawra }\end{array}$ & 19.11 .1929 & Hain & 33 \\
\hline $\begin{array}{l}\text { Informal Diary } \\
\text { Lawra }\end{array}$ & 24.11 .1929 & Tuma area & 577 \\
\hline
\end{tabular}

Source: Weiss, 2004

Other districts affected were the Western Dagomba district where the District Commissioner, Cardinall, was horrified as "hoppers were all over the district" (Weiss, 2004). Here destructions of cereals farms were also reported. Farmers got tired of the locust destroying their crops and decided to stop sowing cereals as long as the locust abounded. The District Commissioner advised the chiefs to inform their communities to alternatively start growing yams and beans following food shortage and famine that plagued the district.

Around the late 1920's and 1930's, locust invasion coupled with adverse climatic conditions like erratic rainfall and poor soils led to poor yields and subsequently increased widespread famine and hunger (Weiss, 2004). In the opinion of Grischow (2006) even though food shortages in the Northern territories were reported every two years, nothing was being done by the colonial administration to alleviate this plight. After the First World War, to improve the welfare of the people, the Colonial Development Act of 1929 was introduced. This act promoted agriculture aimed at eradication the tse tse fly which affected livestock, especially cattle and promoted mixed farming (Grischow, 2006). It also facilitated the creation of a Nutrition Committee (NC) to examine the problem of malnutrition prevalent in this region (Worboys, 1988).

The colonial administrators and native authorities from the different provinces met to discuss different strategies which could be adopted to survive the plight of the locust. Deliberations from these discussions centered on the cultivation of non-destructible hopper crops like 
yams and other root crops in the Southern and Northern Provinces. An embargo was placed on the exportation of guinea corn to the South in the Southern Province, but the Dakpema reported cases of cereals being exported to the South illegally.

A relief fund to feed the population and provide them with seeds was carried out by the Native authorities in the Buipe area and in the Savelugu division, about 700 loads of guinea corn was also provided by the Native authorities to be distributed. In the Northern Province, the District Commissioner opted for a food for work programme, where all the men were employed to construct the Navrongo-Zuarungu road in exchange for food. This project saw the employment of over 500 men until the end of the year. Weiss's (2004) analysis of the locust invasion period in the Northern Territory brings to light aspects of governance between the chiefs and the colonial government. In this example, we see a co-construction of governance by the chiefs and colonist to solve problems of famine and hunger in these provinces, as they come together to deliberate and implement strategies agreed upon by all.

Even though relief policies were reached, one of the early difficulties was convincing farmers to start cultivating root crops, a practice they had not indulged in before, especially around the Navrongo area. The farmer's reason for not adopting this new policy in their words was 'our fathers never grew them' according to information in the informal diary written on Navrongo community in 1930 cited in Weiss (2004). This example brings to mind Foucault's notion of subject making, as discussed in Chapter 2. Here we see the farmers resisting change and governance policies by the colonist using historical recollections of their farming experiences and practices. The unavailability of digging sticks and enough seedlings also posed a challenge to this large scale project. This project to introduce root crop to farmers in the Navrongo area was later aborted.

Weiss argued that this project was a 'colonial propaganda' used to showcase colonial interventions in reducing famine and hunger, where more effective and efficient interventions could be done but were not done. This 'colonial propaganda' led to increased yam cultivation in other areas like Wala, where changes in household food consumption were noticed. Yam consumption increased compared to that of other staples. Yam was prepared as the staple food to be eaten with the vegetable soup. The women also preferred yams preparation to maize, millet or guinea corn, which were more labour intensive. Communal yam farms were developed in the Builsa Native administration and Lawra-Tuma district. The Dagombas who were already known to cultivate yams produced surpluses which were exported to Kumasi and Accra in the South. Here we see how governmental intervention by the colonial government has reshaped the agricultural practice of its subjects the farmers who diversified their crop production.

Rice was also given special attention by the colonial government for a while when they thought it could be a future cash crop that would boost the economy of the Northern territories. 
Rice was chosen because it was not affected by the locust and had potentials of being a cash earner for the local farmers with the intent to reduce poverty and hunger, but also it was meant to provide funds for the colonial government if they operated large farms and exported it back home. This project partially succeeded as farmers started planting rice, but it did not attain the potentials for export. The traditional fast maturing guinea corn seeds from the Southern province known as red guinea corn or kajie were also introduced in the Northern Province, but little is said about the success of this particular project. Lynn, C. W., an agricultural Superintendent proposed alternatives and diverse crops like pigeon peas (Cajanus cajan), cassava (Manihot esculenta) and sesamum (Sesamum indicum) to remedy the food shortages caused by locust invasions.

Despite efforts put in place to promote the cultivation of alternative crops; some colonial agricultural experts like Shepard, C. Y. argued that the Northern territories are the most problematic part of the Gold Coast, plagued by irregular rainfall, poor soils, bushfires, locust invasion and rinderpest epidemics, all of which are detrimental in any agricultural activity. Shepard pointed out that another factor which slowed down agricultural growth was the conservative and somewhat primitive social organization of the people who, in refusing to leave teh graves of their ancestors in order to relocate to collonial farms, also contributed to the food shortages in this region. This positioning of natives in the minds of the colonial administrators greatly differed, as some District Commissioners believed the natives could solve their own socio-economic problems with and without aid from the colonialist. This shift in the mindset of colonialist about the natives' potentials contributed to the introduction of a more modern, technical and scientific approach to the economic crisis in the Northern Territories to improve the wellbeing of the people.

Sutton (1989: 640) states that sporadic attempts were made at generating a cash economy in the North as "experimental agricultural and livestock schemes were initiated, dropped and revived several times in the course of the colonial period." The changes introduced in the agricultural sector focused on soils and water conservation and also mixed farming - where animal husbandry was integrated with agriculture with the use of more manure. Experiments were carried out on existing crops found in this region like cotton, shea butter, grains, groundnut and also on livestock. Many reasons account for the failure of the different agricultural and livestock experiments. Each venture was treated as a new idea without reference to other past experiences. There was little or no coordination between the different organisations implementing these projects over time and space, leading to a waste of time, money and resources. The aim of the colonial council in reviving agriculture and exporting raw materials like cotton to Europe, livestock to the South did not yield any fruits. In this example we see how governmental interventions with the aim to improve the livelihood of the masses as stated in $\mathrm{Li}$ (2007a), does not succeed, due to different interest and agendas by the actors. 
The fleeting consideration of tobacco, dawadawa, rice, and shea butter as cash crops was problematic due to numerous factors. First, there was the absence of a good transport system. Secondly most of the crops were not suited for mechanisation. Thirdly there was a lack of technical expertise to fix any machine that broke down. The British colonial government invested a lot in the experimentation with cotton as a possible cash crop. The British Cotton Association even introduced cotton hybrid seeds. Animal traction was introduced especially for this particular cash crop farming practice with ox- carts fabricated from wrecked cars, as the "main implement used is a heavy ridger pulled by paired oxen" (Blench, 1999: 19). These technologies were introduced first to chiefs, with the idea was that if the chiefs adopted these technologies, and then the people will do same. Chiefs, in this case, were used by the colonial administrators as an Obligatory Passage Point (OPP) to get the people enrolled in the project. The OPP is a concept that comes from the Actor Network Theory by Callon and Latour, previously explained in Chapter 2 . New farm technologies were introduced to the chiefs by the colonists who believed that if chiefs adopted these technologies, other farmers would be convinced to adopt them too. This process of enrollment, as explained in Chapter 2 , is a process through which an actor, or actors, convinces other actors to join his ideological network by using discourses or intermediaries which the other actors accept. Even though many technologies elaborated above were not adopted by the people, intercropping of maize and millet fertilized with manure collected from animal kraals close to the compound was adopted by many farmers (Sutton, 1989).

Sutton (1989) also discusses the large-scale groundnut farm opened in 1955 under the Gonja Development Company Scheme. The idea was that the company would acquire the land, plant, harvest the crops and sell. The farmers were required only to weed the crops, and when sold, they would be given a third of the profit. This project invested in the use of chemical fertilisers, tractors, and the crop rotation method. About 4000 acres of land was acquired, and expectations were to get roughly 400 farmers to settle and work on this farm. This project ended at the experimental phase with only 15 permanent farmers on site. Reasons for this failed project were that the farmers did not own the project, and found it taxing to relocate to this project farm to settle and farm. As opposed to the intercropping example above, farmers are resisting governmental interventions by the colonial government, and in this way reshaping the governance system in place by not legalising their power and authority in controlling the agricultural system.

Irrigated dry season or market gardening on small protected plots was introduced by the Society of Missionaries of Africa (White Fathers) who grew vegetables around water bodies first in the upper East region as stated by Wardell and Fold (2013). The vegetables cultivated were mostly exotic, that is, vegetables foreign to the local diet. Vegetable cultivation increased in the city as the colonial administrators each had gardens where they cultivated 
vegetables and flowers for culinary and aesthetic purposes, especially in the Gold Coast (as explained in Chapter 1 and section 4.3) (Obusu-Mensah, 2002). In the North, vegetables were grown in compound and bush farms; these vegetables were generally grown in the wet season and dried for culinary use in the dry season. In a letter dated $12^{\text {th }}$ April 1949, the Department of Agriculture requested that the District Commissioner hand over a vegetable garden in Choggu to an ex-serviceman called Mr. E. N. A. Boatey. This transfer was meant to facilitate the payment of rents for the land to the appropriate quarters (Ref No.0179/1). This shows that dry season vegetable was also practiced by the local people, but not on a large scale, compared to rain-fed vegetable agriculture which was a predominant practice because of the climatic condition in this agro-ecological zone.

In the livestock domain, cattle, sheep, goat, horses, donkeys, pigs and poultry of various types were kept by the Dagombas. There were no intensive productions systems of animal rearing in the region, and small livestocks were allowed to forage freely in the dry season and confined in the wet season (Weiss, 2004). Technological changes started in this sector with the importation of cattle from Europe, with most of them dying before reaching the Gold Coast or shortly afterward. The few that survived were crossbred with the local cattle to produce what Sutton (1989) referred to as half or quartered-bred European crosses, and they were placed in the chief's herds. This practice of passing down new technology to the community through the chiefs, as already explained above, was a popular concept then and is sometimes still applied today in rural agricultural projects.

Later local selective stock breeding was encouraged when Zebu, Mossi, and Ndama cattle were imported from Burkina Faso, Mali, Niger for cross breeding with the West African shorthorn cattle found in the protectorate (Mahama, 2009). This new breed of livestock from the French African colonies was given to chiefs of the Dagomba catchment area. Native authority kraals were thus created to increase the cattle population in the region, as old and dysfunctional bulls were replaced with new, active bulls. A veterinary center was set up in Pong Tamale for the treatment of cattle. However, there existed few cattle-owning families who were not capitalist-oriented. Thus, the objective of increasing cattle population for commercial purposes by the colonial administrators did not succeed (Sutton, 1989).

From the pre-colonial to the colonial period Shaffer (2015: 9) argues that "by most accounts, agricultural practices in the 1930s were essentially unchanged from earlier times. The staple crops remained millet and guinea corn which were cultivated using the same techniques as in the earliest times". This he corroborates with an observation made by an agricultural officer Lynn, C. W, who describes agricultural activity thus: 
Men wander over the farm with long sticks and make holes at random, and women and children follow with the seeds in a calabash... the precarious food situation was due primarily to ... methods not sufficiently intensive for the conditions obtaining (Lynn, 1942: 81).

The citation above reflects the contemporary agricultural practice of the Dagomba people, from my observation during fieldwork and even discussions with other colleagues who have interacted with farmers in peri-urban and rural areas. The slight difference is that a few farmers now use tractors on their fields. Sutton (1989) relates Gunder-Frank's metropole-satellite framework, used in his study in Latin America, to the case of the Northern territories and the Gold Coast in Ghana. Gunder-Frank's framework seen in Figure 4.5 stated that metropolises were not only centers of intercourse but of exploitation, and he related this to the socioeconomic and political relationship between the third world countries and the capitalist economies. The capitalist economies are meant to stay developed at the expense of the underdeveloped countries. Sutton uses the center-periphery relationship of Gunder-Frank to explain the relationship between the then Northern territories and the Gold Coast as designed by the British.

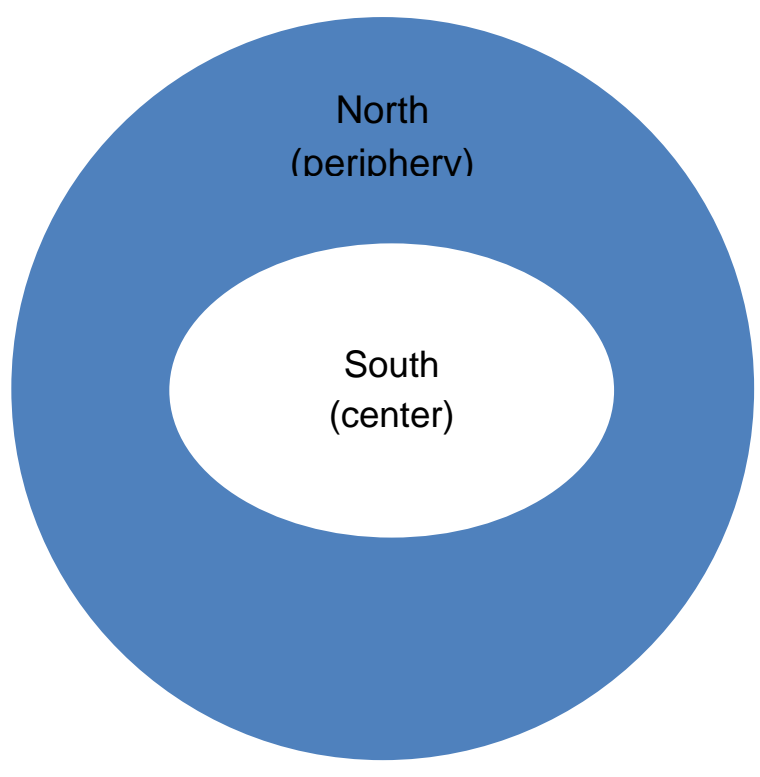

Figure 4.5: Center and periphery relationship between the Northern and Southern region in the Gold Coast

Source: Author's construct, 2014

Sutton states that the North was a labour reserve for the South and its administration was left at the mercy of the development in the South. This idea of the North being a labour 
reserve for industries and plantations in the South is supported by many authors like Ladouceur (1979) and Nii-K (2007). Weiss (2004) also supports this idea when he states that the work for food programme and the use of compulsory labour retarded development in the North in favour of the South. In addition, cheap food and good prices for labour rendered in the South also encouraged North-South migration in the Gold Coast colony. Southern development was important to the European economies, so labour from the North was solicited to boost the southern economy through mineral extraction, oil palm exports and rails constructions (Blench, 1999). This altered the North's position as a food supplier to the South and crippled little of what was left of its economy. The colonial government's opinion on the North-South divide was evident from some of their statements:

I cannot too strongly urge the employment of all the available resources of the Government upon the development of the country south of Kintampo... I would not at present spend upon the Northern Territories - upon in fact the hinterland of the Colony - a single penny more than is absolutely necessary for their suitable administration and the encouragement of the transit trade... until the Colony and Ashanti have been thoroughly opened up and developed, the Northern Territories must be content to await their turn (Kimble, 1963: 533-34).

In this section, I have discussed the emergence of a semi-mechanised (use of animal traction) agricultural system based on mixed farming and improved livestock rearing which was introduced during the colonial period. These factors had little or no effect on long-established norms of agriculture when it came to land allocation, labour distribution, and agriculture output. This was because land allocation was mainly in the hands of the chiefs, who still controlled agricultural resources supervised by the colonial administration. The agricultural system can be said to have changed only slightly with the adoption of improved hybrid and pollinated seeds by commercial and smallholder farmers through projects participation. Many of the agricultural and livestock innovations either died at the experimental phase or after subsidies attached to the projects came to an end. The colonist's strategy of using the chiefs as intermediaries to convince farmers in the community to adopt these new technological packages did not work, as chiefs were not really interested in these projects.

Furthermore, some of the District Commissioners resorted to the use of unpaid labour for road construction, government buildings and courier services, causing many young men to flee to the South where they were sure of payment for labour services. By resisting the governance system in the North and moving to the South, the people fitted into the global British governance system in their colonies, which was economically oriented. This migration 
trend had a negative effect on the agricultural sector in the North but a reverse effect in the South. Thus, interactions between British Governors in the North and South to promote British interest were fulfilled, at the expense of Northern development.

The social structure of the family also changed significantly, as many women became family heads in the absence of their husbands, who had migrated to the South. Women, in this case, made daily decisions, which were supervised by their male kins who had not moved down South. This situation did not give them direct access to resources such as land. Food was mainly bought by the men who went to work in the South to feed their families. This probably contributed to the Dagomba culture where women are primarily involved in marketing and men in farming. Women continued processing shea nut and dawadawa for spice, food, and cosmetics as a survival strategy and source of livelihood for the family. In the next section, I will examine if any recent changes have altered the agricultural system with the introduction of projects by many multilateral organisations, and if this has reshaped resource access and control in any way.

\subsubsection{Post-colonial era}

After independence in 1957, the new government of Nkrumah realised that the economy of the country had to move at a fast pace to catch up with the rest of the world, as mentioned in Chapter 1. Representatives from the Northern territories had demanded a speedy economic and social development to catch up with the rest of the country. They wanted roads, schools and other basic socio-economic amenities and services. This view by representatives of the Northern territories reflected those of many colonial administrators in the writings of Sutton (1989) and Brukum (1997) who had argued that the lack of a proper transport system and other social amenities was an impediment to any agricultural improvement or development as a whole in the Northern part of Ghana. In the opinion of Asuming-Brempong et al. (2013) the agricultural policy in the 60's shifted from a capitalist ideology to a socialist one under Nkrumah, where large tracts of government managed farms and cooperatives were opened up and government subsidies in the form of fertilisers, tractors and improved seeds made available for agricultural production in the North (Chapter 1). The Agricultural Development Corporation (ADC) was created then to spearhead this agricultural modernization and to exploit the economic opportunities at that time.

As stated in Ouma (2015) and Blench (1999) from 1964 to 70's, with the overthrow of Nkrumah, a military regime took over and changed the agricultural system from socialist ideologies to a capitalist ideology, with calls for more investments in commercial food production. Cooperatives, private-led rice investments, and cotton farms were promoted. The Agricultural Development Bank (ADB) was enacted to support and provide needed credit to promote agriculture through an Act of Parliament (Act 286) in 1965 under the name of the Agricultural 
Credit and Cooperative Bank. This credit facility was mostly accessed by literate community members who were able to obtain the necessary documents needed to guarantee bank loans and get a written registration of land holdings. This governance technique was used by the state as a mechanism to control access to land and other resources for farming. This technique excluded poor community farmers, who could neither gain access to these credits nor get registered land holdings.

The acquisition of large mechanised private farms led to the creation of a new group of farmers known as urban-based capitalist farmers who were different from communal farmers, as most of them were civil servant personnel, private investors and ex-military (Goody, 2007). They were more interested in commercial cash crop cultivation and had an entrepreneurial spirit. Their easy access to credit, loans, and land holdings created resentment amongst the indigenes because they could not benefit from this system of farming since they did not have the money or connections to get loans and guarantee land holdings. Moreover, as stated above, this method of acquiring land was in competition with the local people's procedure for having access to land. Villagers rebelled against this form of land acquisition by destroying machinery on the farms and burning the rice fields (Goody, 2007; Konings, 1984). This goes to solidify previous discussions that governmental interventions are not always accepted by subjects but are sometimes resisted, creating multiple governance systems. Indigenes, in this case, used the traditional norms on land acquisition to fight against the commercial agricultural system in place, thereby legitimising the traditional governance system. Blench (1999) was also of the opinion that "similar attempt to develop large-scale mechanised farming would be subject to similar problems," in any near future. He also warned that state intervention on land administration and management could easily lead to the individualisation of lands, a phenomenon which is now widespread in urban and peri-urban Tamale as discussed in Chapters 1, 5, 6 and 7.

Muslim migrants such as the Zarma and the Hausa are presumed by Blench (1999) to be some of the first people to practice horticulture in riparian areas in the Northern region, even though he does not specify the year this activity started. The White Fathers also practiced vegetable gardening along water bodies and around shallow rivers. This practice became more predominant in the dry season, which is a time when little agricultural work is done. This is because agriculture is a predominantly rainfed activity that is usually carried out for only 120 days a year in this region according to Gyasi et al. (2014), with gardens mostly found at the edges of dugouts used for agricultural and domestic purposes.

In the early 1970's the capitalist ideology was pushed aside and a semi-socialist or 'nationalistic' system taken up by the Acheampong's regime. Obusu-Mensah (2002) mentioned that during this regime, due to the economic crisis and famine the 'Operation feed yourself' programme was launched. This programme was introduced as a result of high inflation 
and scarcity of basic commodities - as a result of political upheavals and droughts in the country. The country had large external loans which were yet unpaid. To salvage the economy Acheampong instituted the yentua policy (we shall not pay) and the international community responded by cutting all external credit and aid to Ghana. This resulted in food shortages exacerbated by the 1983 droughts. This programme legitimised interstitial farming in the city with no fear of crops destructions, as the bylaws on urban agriculture were relaxed to increase food supply in the community (Asomani-Boateng, 2002). This programme permitted urban agriculture for everyone and not just for the government administrators, as was the case during British colonial rule, where only colonial administrators were allowed to practice urban farming. From the discussion above, political interest and international relations have a direct effect on the socio-economic environment of a country and indirectly its agricultural system.

Urban dwellers got involved in patch agriculture as a source of survival and also as a source of secondary income. During this time smallholders' farmer were favoured in comparison with large scale farms owners. Most of the nationalized farms introduced by Nkrumah had fallen apart (Asuming-Brempong et al., 2013; Girdner et al., 1980). Urban agriculture in the city grew during this time as opposed to the colonial era where city planning did not permit urban agriculture for everyone due to health and hygiene reasons (Obusu-Mensah, 2002).

Table 4.2: An urban farming survey carried out in Accra

\begin{tabular}{|l|l|l|}
\hline Cultivation period & Frequency & Percentage \\
\hline Before 1966 & 20 & 10 \\
\hline $1966-1975$ & 67 & 33.5 \\
\hline $1975-1985$ & 55 & 27.5 \\
\hline $1986-1995$ & 58 & 29 \\
\hline Total & 200 & 100,0 \\
\hline
\end{tabular}

Source: Obusu-Mensah, 2002

The data presented in Table 4.2 above was collected in 1966 by Obusu-Mensah (2002) in Accra in order to find out when people started getting involved in urban agriculture. The number of individuals interviewed and sampling method used in collecting the data is not mentioned. The above table is just a reflection of the history of urban agricultural practices in changing political times. From the table, a rise in urban agriculture can be seen from 19661975, during the operation 'feed yourself programme' introduced by Acheampong, when Ghanaians were encouraged to grow food and feed themselves. This practice declined during Rawlings' military rule in Ghana when droughts and famine took over the country. The reason 
for this decline in urban agriculture could be due to government agricultural policy and intervention which focused on rural than urban areas. Even though urban farming is still being practiced in the Ghanaian society and in many West African cities, it has not been integrated into the planning schemes in the towns and its considered illegal except in few countries like Tanzania, Uganda, and Kenya according to Lee-Smith (2010).

In the 1990's donkey carts were introduced from neighbouring Burkina Faso to aid farmers in transporting manure, compost and tools to farms and later food to markets for sale. Even though donkey carts were very useful to farmers, the prices for these carts remained a main financial obstacle for many farming families (Blench and Dendo, 2007). When these carts developed faults, they were often abandoned due to the lack of technical expertise in the region to work on it, so many farmers did not adopt this technology. Farmers presently using donkey carts are the wealthier farmers. Tractors were available as subsidies flowed in but with the end of these subsidies only a few wealthy farmers had tractors which they hired out to other farmers at the start of the planting season (Blench, 1999). From the above information, governmental interventions were sometimes not accepted by the subjects not because they were not good, but due to other socio-economic factors like the lack of finances required to acquire and maintain these resources.

The post-colonial period saw a lot of investment by multilateral and international agencies in rice and maize cultivation - in irrigation sites and natural floodplains (Blench, 1999). Socio-economic and political policies like the Poverty Reduction Strategy (PRS) which is an extension of the Structural Adjustment Programme (SAP) was introduced by the government and facilitated by the World Bank (WB) and International Monetary Fund (IMF). Even though these policies were put in place to improve the failing economy of the country, the reduction of subsidies contributed to the lapse in agricultural development and research (Briggs et al., 2001; Lipton and Ahmed, 1997). Agricultural projects did not all cease, as several initiatives on smallholder projects on crop cultivation and livestock were launched by international agencies such as the Food and Agricultural Organisation (FAO), and later the International Fund for Agricultural Development (IFAD). These projects were mostly carried out by local nongovernmental organisations in collaboration with the Ministry of Agriculture, sometimes in what Ferguson and Gupta (2002) refers to as trans-governmental interventions or transnational governmentality.

According to Blench (1999), a Northern Region Integrated Project was also conceived to take an integrated approach to planning and agricultural development in the Northern region even though it did not achieve much. The World Bank initiated a National Livestock Services Project (NLSP) in 1993 to improve veterinary care through the construction of communal water holes and introduced the use of improved pastures. Non-Governmental Organisations (NGOs) 
like the Save the Children Fund, the Adventist Development and Relief Association and ActionAid were and are important players in the agricultural system in this region, where government contributions are not significant as mentioned in the World Development Report (2006). Many of these projects by international development agencies are carried out to legitimise their authority in this country and status in the development arena.

In the section above I discussed how different political regimes addressed agricultural activities especially vegetable cultivation. It was clear that urban agriculture became widespread as a result of governmental interventions which encouraged it and declined when the agricultural policies changed. Food production and consumptions patterns in this region have changed significantly due to the adoption of different technological packages from various national and international NGOs. Many of such technological packages were agricultural inputs such as improved seeds, fertilisers, and tractors.

Recent technological packages introduced in the horticultural sector are drip irrigation in Sakpehalegu and Gumbihini old dam site, solar irrigation panel in Fooshegu and Daitoyili, organic compost and improved seed varieties in Gumbihini, Ganasco dam, and many other sites. These technologies are changing the pattern of vegetable production and consumption in this region, especially in Tamale, as more middle-income urban dwellers are consuming more vegetables than before. A mixed farming system is now practiced in which livestock owners use manure from their animals to fertilise their fields and those who do not keep animals buy or secure freely chicken droppings to use for their vegetable gardening, like in Sangani. According to a focus group discussion in 2014, I was informed that farm inputs like fertilisers and water pumps are mostly used by farmers when they come at a subsidised rate. This is the case with water pumps used by farmers in Tuunayili. The end to subsidies for water pumps and fertiliser has forced farmers to look for cheaper alternatives through visiting researchers like me.

Lands for compound and bush farms are still accessed by obtaining usufruct rights from chiefs. Men are still in control of access to land and rely heavily on household labour on their farms. However, a new trend of hired labour was observed on government irrigation sites where women are recruited to harvest vegetables in exchange for money or, sometimes, the harvested vegetables, as discussed in Nchanji and Bellwood-Howard (2016b). Farming in the North is no longer subsistence but it's semi-subsistence as many governmental interventions even though not well linked has led to changes in the agricultural practice in this region. These variations in the agricultural sector have legitimised development projects carried out by national organisations with foreign aid and also resulted in co-constructions of governance systems as subjects accept and resist governmental interventions. The shift in political ideology from socialist to capitalist camp and vice versa has over the years affected the agricultural system of Ghana, as can be seen in the different governmental interventions during these 
different political regimes and has slowed agricultural progress especially in this region. In the next section, I will focus on the emergence of vegetable farming and how it is being managed in the advent of urbanisation and increasing population growth.

\subsection{Vegetable cultivation and the advent of urbanisation in the North}

As already explained in previous sections and chapters, vegetable cultivation is a long-standing activity that took place in the backyard or household gardens, and even in bush farms, during the pre-colonial era in the North and in the world as a whole (Benneh, 1968; Niñez, 1987). It was an activity that was traditionally attributed to women who had a responsibility to provide ingredients to prepare the vegetable soup for the household to be eaten with starch cereals provided by the men (Apusigah, 2009; Musah, 2013; Nchanji and Bellwood-Howard, 2016a). It is assumed that this gender distribution of labour might have resulted from man's preoccupation with hunting and livestock rearing, and a wife's responsibility to harvest vegetables and make a stew which will be eaten with grains supplied by her husband (Benneh, 1968). Women accessed land for vegetable cultivation through the males in their households or lineages. These farms were either cultivated with their husbands or individually. Most of the farms consisted of not only vegetables but also cereals like maize and millet.

During the colonial era, exotic vegetables were introduced by missionaries and different European administrators (La Anyane, 1963). However, according to Asomani-Boateng (2002: 593):

The rearing of livestock, poultry and cultivation of indigenous staple crops was not permitted by city officials for health reasons, and this trend continued even after independence in $1957 \ldots$ officials of various Town and City councils were instructed to destroy any crops growing in the city, as well as animals found roaming the streets, and the farmers responsible were prosecuted for compromising city health.

During the operation 'feed yourself programme,' as mentioned before, the government began to tolerate farming in the city due to the economic crisis and hunger at that time. As mentioned above, we see how different political interests influenced the agricultural policy and consequently urban agriculture.

With the advent of urbanisation, the value of land increased as a result of a real estate market resulting in lucrative land markets. Chiefs are taking advantage of this lucrative land market to allocate agricultural lands to estate developers for commercial and residential purposes, as already discussed in Chapters 1 and 3. Many vegetable farmers have lost their lands in the city center over the last six years as shown below in the Buipela site, while some 
farmers are moving to the peri-urban areas in search of land with water bodies for vegetable cultivation in the Datoiyili site, for example, as shown in Figure 4.6.
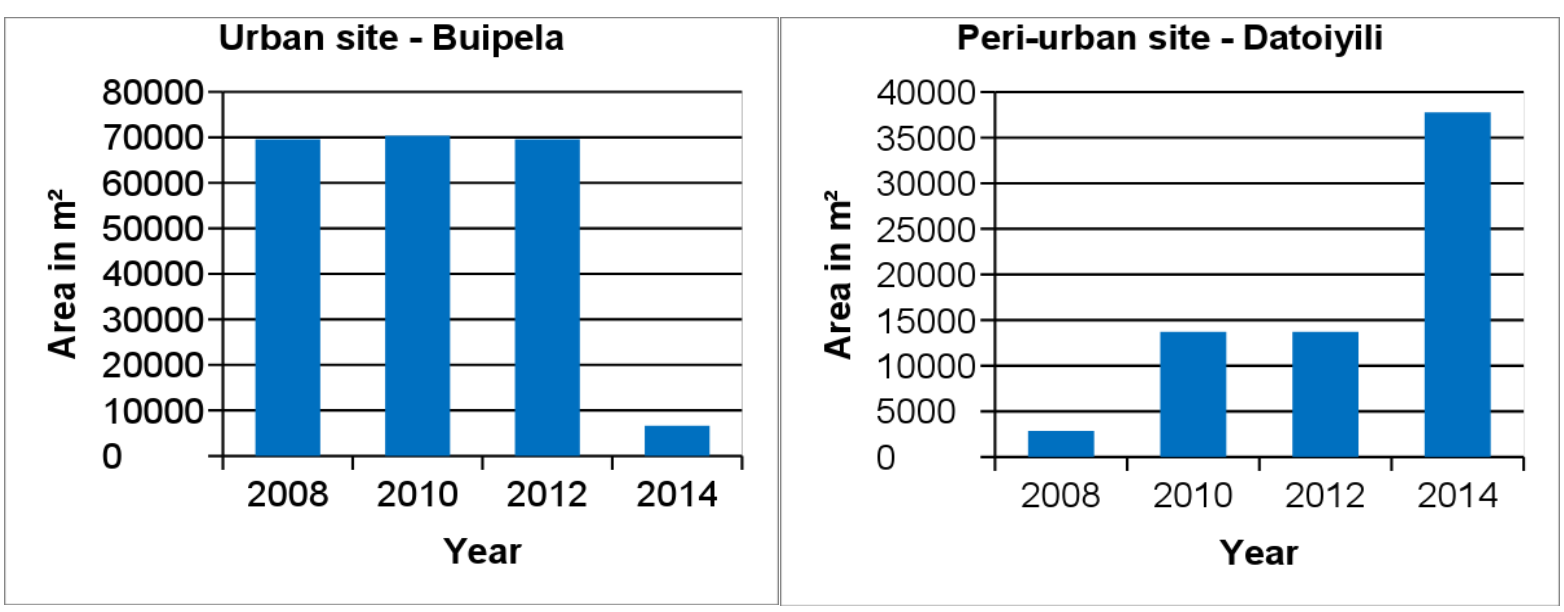

Figure 4.6: Graphs showing different land use patterns over a period of six years in an urban and peri-urban vegetable site in Tamale

\section{Source: Author's fieldwork, 2015}

Farmers who have decided to continue farming in the city are re-negotiating with different actors who own or control lands. The process through which farmers gain and maintain access to these lands will be discussed in Chapters 6 and 7. For example, farmers are negotiating with private undeveloped lands owners to continue farming while acting as land guards against encroachment (Drechsel and Dongus, 2010). It should be noted that even though urban agriculture is tolerated in the city and practiced by urban dwellers, farmers did not move into the cities to farm. Rather, urbanisation engulfed rural areas in the 80's, which have now become new urban and peri-urban areas. These changes in land use are clearly seen in the work of Erfurt shown in Figure 4.7. 


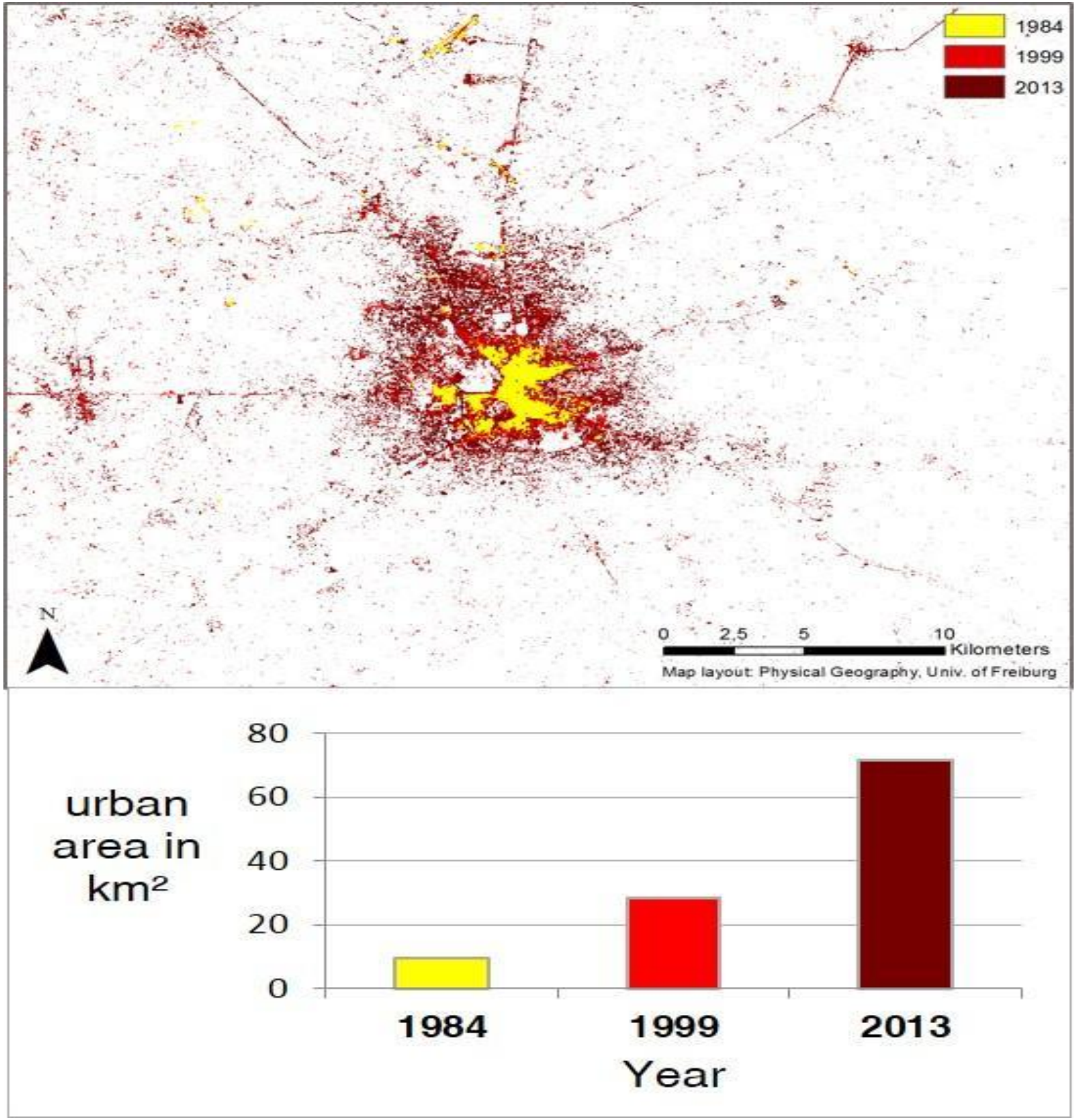

Figure 4.7: Land use changes of Urban Tamale from 1984 to 2013

Source: Erfurt, 2014

From interviews, new labour relations have emerged in irrigation sites as a result of the diffusion of gendered agriculture postulated by many local and international non-governmental organisations including the Urban Agricultural Network, New Energy, and the United States Development Agency. Even though these changes are occurring, women are still more involved in vegetable harvesting and marketing than production.

The traditional method of growing vegetables around dugouts, reservoirs and gutters are still maintained, but new technological changes are also being witnessed. More farmers are using water pumps as compared to watering cans, more fertilisers and pesticides are used, 
especially in cultivating exotic vegetables, which are more profitable according to Seidu (2009) and consumed by the new urban class in urban areas. New technology like drip irrigation, mixed farming and use of solar powered irrigation techniques have been introduced in this agricultural milieu with positive and significant results in commercial vegetable production and sales.

In the above section, we see changing labour relations, especially in urban farming with a gender sensitive agricultural system in place, where women are being allocated lands in irrigation sites by the state through influences from international agricultural development agencies. Here we see how the interests of many international organisations are being implemented in many developing countries, through gender-sensitive policies. These governmental interventions over time have been resisted and accepted resulting in different governance systems and changing agricultural practice. Different political ideologies have also influenced the vegetable agricultural practice with a change from a subsistence system to a semi-subsistence one, where commercial vegetable agriculture is prioritised over predominant subsistence farming. The idea of transnational governmental interventions is predominant especially in Tamale, which is an NGO city in Ghana.

\subsection{Conclusion}

In this chapter, I examined how shifting power relations between the tindanas and chiefs have changed rules in gaining access and maintaining control over resources, and how this has restructured the agricultural system. This shifts in power relations has also structured labour relations in the family and society, as subjects were automatically expected to work in the fields of the chiefs for free while taking care of their own fields.

Chiefs' control over land has been justified by historical recollections and colonial influence in what authors like Fuseini and Kemp (2015) and Nchanji and Bellwood-Howard (2016a) refer to as "the reinvention and reconstruction of tradition," which will be explained in detail in the next chapter.

Different political regimes have over the years enacted different techniques in the form of policies, programmes and projects through which they have governed the people from afar. These projects, programmes, and policies were meant to reshape the agricultural practices of the people from a subsistence system to a more mechanised or industrial system. These governmental interventions were sometimes accepted and resisted by the subjects, creating new or sometimes hybrid governance systems, as summarised in Figure 4.8 below. Most of these projects and programmes, as explained above, were meant to serve the interest of the intervener and also to position them as credible and fundable organisations in the development world. 


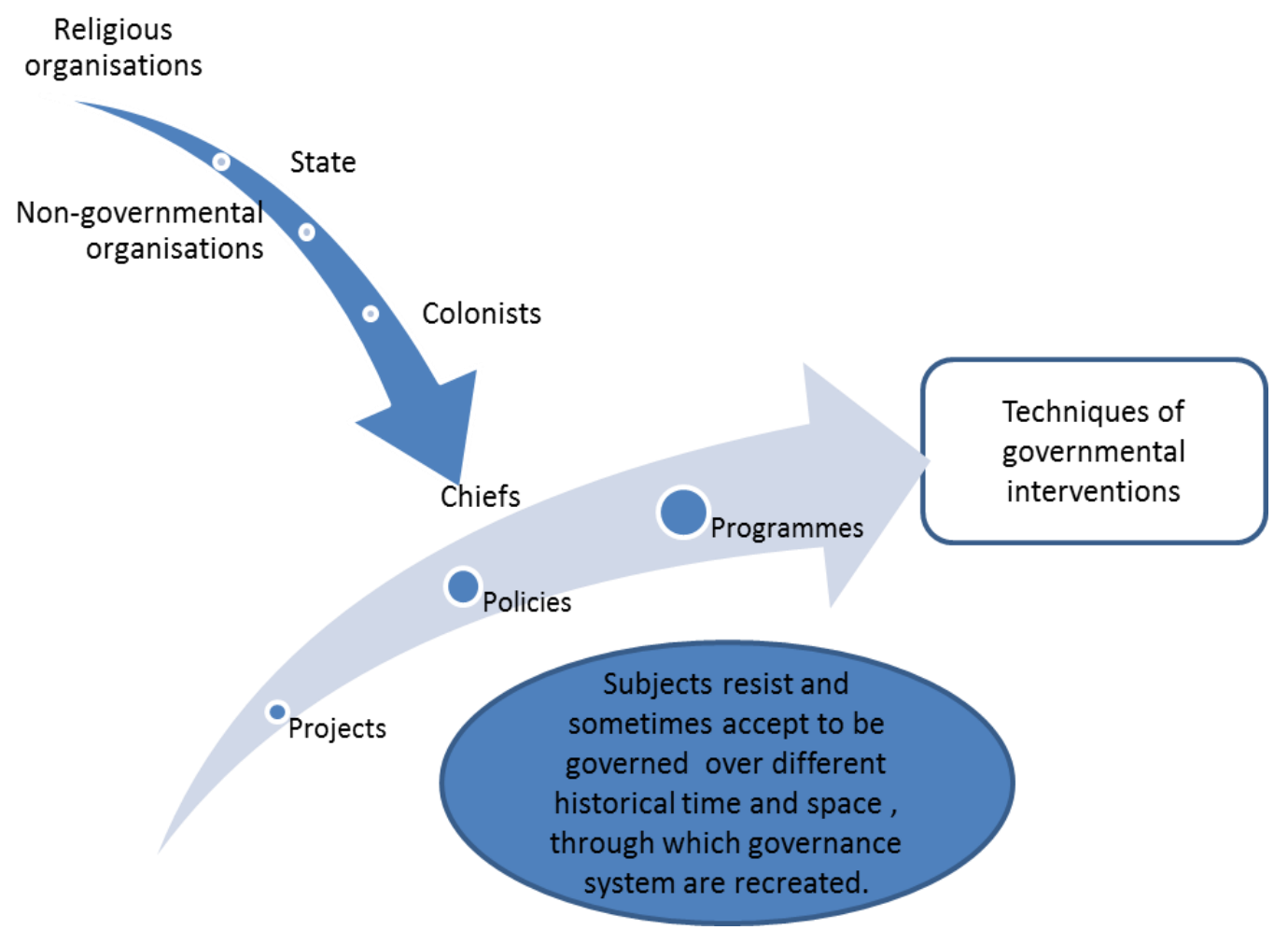

Figure 4.8: A diagrammatic illustration of governmental interventions

Source: Author's construct, 2016

In addition, changing agricultural policy has also influenced practice of urban agriculture in Ghana. The practice of urban agriculture is used by non-governmental organisations to legalise their activities which are embedded in the idea of food and nutritional security. Due to the high rate of poverty and food insecurity in Northern Ghana, agricultural projects and programmes are always embraced by the state and sanctioned to take place, even though these projects are generally not linked, as interveners compete against each other. In the next chapter, I will explain how uneasy relationships between the chiefs, colonists and the present government have reshaped the land tenure system in Ghana, as well as property rights. 


\subsection{Conclusion}

In the first section of this chapter, I situated vegetable farming in the wider socio-demographic and physical landscape of the Tamale Metropolis. I explained how Tamale came to be the administrative and economic center of the Northern region. As one of the fastest growing cities in Ghana if not in Africa with an annual growth rate of $7.2 \%$, Tamale is experiencing serious pressure against its natural resources. Urbanization has created a lucrative market for lands which are frequently being sold by local chiefs for their private gains. This has resulted in two things; intensive farming on the one hand and migration from the urban center to peri-urban areas in search of farmlands by farmers on the other. The physical/geographical characteristics also has an effect on agricultural activities. For example, the unimodal rainfall pattern and the climate variability of have allow for just one major agriculture production season in northern Ghana since most agricultural production is rain-fed. Given that farming is a major source of livelihood and irrigation infrastructure is limited, underemployment during the dry season is high among the local populace, but dry season farming is now reducing poverty and unemployment during the dry season. Despite the tremendous shift towards the service delivery sector, more than $80 \%$ of the population still practice agriculture in one form or another.

I have argued that the lack of synergy and competition between different agricultural development agencies from colonial to postcolonial times is one of the reasons why the agricultural system is still agrarian in the Northern region. Agriculture in the northern Ghana was neglected by the colonial administrators whose development policies largely concentrated on turning the north into a source of labor for the mines and commercial farms of the south. Added to that was a general neglect of northern Ghana`s social and infrastructural needs since most developments were concentrated in the south where the colonizers lived and exploited. The effects of those policies still linger today in northern Ghana In the post-colonial era, successive governments have tried to address the poor state of development in northern Ghana through a number of national development programs. Some improvements in economic and social infrastructure (improved access to energy and transportation for instance) have been achieved as a result of those programs. However, poverty remains a major problem confronting the people of the north. Northern Ghana still remains the poorest region of the country and development inequality between the north and the south continues to widen. Investments have been low relative to the magnitude of the development challenges and many policies lack the commitment to address this development imbalance geographically.

To take account of the different social realities, data was collected using a variety of methods including in-depth interviews, informal conversations, and focus group discussions to gather information on the different socio-political process through which farmers are able to 
access, maintain and control resources like land water and seeds. Quantitative data was gathered and used to triangulate and validate the information on land use patterns and strategies employed by farmers to maintain control over resources for their farm practice which were obtained through the qualitative methods.

In carrying out this study, there was a need to understand the background of the research area and to find out how urban agriculture is situated within its socio-economic and political setting. The researcher positioned herself within the interpretive and constructivist paradigm where social realities are constructed and multiple truths exist. The reason for that was to understand how the different social realities of all the different actors in their sociopolitical settings contributed to a global understanding of resource access and property rights in vegetable farming in Tamale. A mixed method was used to collect data from respondents and farm fields with shortcomings stated. 


\section{Chapter 5 - Land Tenure System in Ghana}

"There is no land absolutely unoccupied, in the sense of being without an owner; it is either the property of the occupant of the Stool or of certain chiefs and headmen." (Letter of Governor Freeling to Carnarvon, 29 May 1877)

"Parliament shall have no power to enact legislation which confers on any person or authority the right to accord or withdraw recognition to or from a chief; and which in any way detracts or derogates from the honor and dignity of the institution of chieftaincy." (Act. 172 (6)), Brempong (2006: 33).

\section{Introduction}

This chapter builds on concepts introduced in Chapter 4 and goes in-depth to discuss how different relationships tied to land influence the land tenure system. Ethnographic data collected shows that land is a vital resource in urban farming in Tamale compared to other resources I have discussed, like water and seeds, as mentioned in Chapter 1 . This chapter will detail a historical perspective of the different land administrative governance systems in the Northern Region of Ghana. The author will examine how the shift in power relations between the chiefs and earth priests gave chiefs control over resources like land, and how the colonist further empowered chiefly land control. Further shifts in power relations between chiefs and the post-colonial government over the years have consistently been reconstructed and shaped to produce the present dual land tenure system in Ghana.

The uneasy relationship between chiefs and different governments provides spaces within which farmers are able to negotiate for and gain access to resources. Overlaps in land management between different government land agencies and also between chiefly and government institutions provide gaps within which farmers negotiate access and control over resources. This chapter provides a basic understanding of the complexities of land reforms in Ghana which have roots in land contestations in the pre-colonial era. Such complexities, as we shall later see in Chapters 6 and 7, are inherent in resource access in vegetable farming. While I discuss resources in general, rapid urbanisation in recent times have called for the need to work on lands, as explained above and in Chapter 1. 
In the chapter's first section I discuss how chiefs came to be positioned at the head of the political system amongst the Dagombas and how this position accorded them the control over resources in this region. This tradition was invented to suit chiefly interest and give them power over resources. The second section will examine how chiefs have maintained their control over resources like land with the aid of colonists. The colonists were interested in accessing land for commercial farming and mining for their entrepreneurial endeavours, and they used chiefs as intermediaries to get access to land for their economic interest. During this period tradition was reconstructed by the chiefs and colonists in order to meet both of their interests in getting personal gain and profit from the different resources within their reach. The third section will touch on the uneasy relationship between chiefs and the post-colonial government after independence.

Government land agencies, like the Land Administration Programme (LAP) will be used as an example to show how land use and administration is changing and being reconstructed by different actors embedded in land matters in Northern Ghana and making chiefs accountable to their subjects on land matters.

\subsection{Traditional land tenure system}

Before the Dagombas in the present day Northern region there existed acephalous groups like the Konkombas who were the first settlers (Imam, 2015a). During this time there existed only a customary land tenure system, as explained in Chapter 3 , where land was administered and managed by the tindanas, and allocated to indigenes and strangers alike after a ritual was performed to cleanse the land (Imam, 2015a). According to Staniland (1975), land was acquired after a token was presented to the earth priest and after land was granted crops were given seasonally as a sign of appreciation. The traditional land administration system at that time was controlled by the tindana through communications with the earth god. The tindana was accountable to his subjects and the gods. The earth priest had to perform annual sacrifices and rituals to appease the gods of the land and the ancestors for making the land continually fruitful. Land was regarded as a spiritual being and was not to be sold, but given out for use whenever the need arises. Power and authority in the traditional land tenure system lay with the earth priest who was considered the custodian of land on behalf of the community, and was enforced through the cultural norm of the people and their tradition.

Iliasu (1971) states that in the $14^{\text {th }}$ century most of the earth priests were killed by Sitobu, who replaced them with his brothers, who were later made divisional chiefs. The role of the tindanas as a land administrator was taken over by the chiefs while the tindanas were relegated to the background with only spiritual duties, such as cleansing the land through sacrifices and rituals. Access to land was still gained through the same procedure; the only difference was that chiefs took over the duties of earth priest in allocating land. Tradition is 
reinvented through political conquest, with powers over land shifting from tindanas to chiefs. According to the District Commissioner of Dagomba in a correspondence in 1936 (N.A.G.T., ADM 2/15):

Right of control is vested in the Ya- $\mathrm{Na}$, for the decision of boundary dispute between Chiefs, but not for the apportionment of land outside Yendi sub-division. Similarly sub-divisional Chiefs have no right to apportion land to persons except within their own towns ... The Chief does not grant farming land to individuals. He is considered not to have any right of control over farms ... Tindamba have still power over Chiefs and are feared.

This is the case in Eastern Dagomba were most earth priests were not killed unlike in Western Dagomba were most of the tindanas were killed by Sitobu with his sons replacing them (Staniland, 1975). The above statement is also true in the case of the Upper East, and Upper West Region, where tindana's still have control over land administration and the chief is just a political figure who does not have direct control over land.

The traditional land tenure system is male dominated except for few exceptional cases where women are chosen as earth priests or chiefs. Some of these women are daughters of the Ya naa as explained by Mahama (2009) who are given specific villages to rule over while others are placed as tindanas in some villages. They also perform the same role as their male counterparts but do not address the people directly in public. They are assisted by male elders through whom they address the people and perform sacrifices taking away their direct authority and power over the people enjoyed by their male counterparts. Here we see clearly how the identity of women has been constructed to limit their access to power and authority over men and women alike even when they are part of the same traditional institutions as their male counterparts. Women's role in the society as explained in chapter three falls under care providers.

In the next section, I will explain how chiefs' control over land is being solidified through a reconstruction of tradition by chiefs and colonist to suit their varying interests and agendas.

\subsection{Transition to a dual land tenure system}

In this section I explain how the land administration in the Gold Coast, which is present day Southern region of Ghana (as indicated in Chapters 1 and 4), influenced the British control over resources, especially in the Northern Territories, which is present day Northern Ghana. I also present the reasons the British gave to justify the changes in the land administration which has reshaped the present land tenure system. I focus on tactics used by the British to 
appropriate land for their economic use in the Gold Coast and Northern Territories using chiefs as intermediaries to achieve their objectives.

Even before the Northern territories became a British protectorate in the $20^{\text {th }}$ century, the Gold Coast was already under the control of the British in 1874, after the defeat of the Ashante, the collapse of the Fanti Confederation Movement, and the withdrawal of the Dutch from the Gold Coast in 1872 (Appiah, 2012; Boahen, 1975; Owusu-Mensah, 2014). In 1876, Lieutenant Governor Lees pushed for a public land ordinance which entitled the government to get any land for public purposes, with the landowners being compensated except in the cases of 'unoccupied land' as per a Colonial Office 96/358 correspondence mentioned in Lahouel (2011). He stated that 'unoccupied land' in this context is any land with no proof of farming, habitation, water collection or industrial activity. This ordinance was denounced by the traditional rulers who stated that due to the traditional farming system of shifting cultivation, lands were always left to fallow and so if the government took control of these so-called 'unoccupied lands' hardship would befall the people.

In later years Governor Griffith, in a bid to boost the economies of European enterprises in the Gold Coast, thought of instituting a market economy where profits will be made by Europeans traders. He charged J.T. Hutchinson with framing a bill on how land could be acquired by the crown for the benefit of European companies. Investigations carried out by Hutchinson stated that the land tenure system was extremely complex (Lahouel, 2011). Three type of land ownerships were identified: stool land, family land, and 'private' land (Sarbah, 1968). Stool land belongs to the ancestors with the traditional rulers as custodians of these lands. The chiefs cannot allocate land without permission from the elders (Busia, 1968). Family land was acquired through purchase or inheritance but was controlled by the family head, who made decisions after consulting with the family. Lastly, the term "private lands" referred to land owned by a kinship group or lineage. It was controlled by a lineage head in consultation with families in this lineage (Busia, 1968).

Family and private land owners gave usufruct rights to members growing crops on these lands. These lands could not be sold by the one cropping without the consent of the different family heads (Sarbah, 1968). In Hutchinson's opinion, it would be difficult for land to be vested in the crown without encroaching on one or more of the land rights explained above. He believed that the people who had sentimental and economic attachment to their land and any expropriation will generate problems. Hutchinson suggested that it was best if the crown targeted forest areas and minerals for appropriation since most of the natives did not view them as a source of profit (Griffith to Ripon Conf., 29 Aug. 1894).

The 1894 Native Bill was an attempt by the British government to vest all forest, waste land and minerals in the crown. The indigenes protested against this bill, and it was withdrawn. Three years later the new Governor Maxwell, introduced the 1897 land bill, which stated that 
all stool lands were to be considered public lands under the control of the Governor with chiefs as trustee. Chiefs were not supposed to exercise any control over the land without the approval of the Governor and all unoccupied land after three years became public land (Appiah, 2012; Lahouel, 2011). This sparked resentment amongst the chiefs and the local elites who saw this act as an infringement on the power and authority of the chiefs in land administration. They believed that the colonial government wanted to swindle their land from them (Lahouel, 2011).

The Aborigines Rights Protection Society (ARPS) - made up of traditional rulers, intellectuals elites and local businessmen - created in 1897 to protect the tradition and customs of the people from going into oblivion (Kimble, 1963; Tenkorang, 1973). The ARPS mobilized the masses to support their petitions against the 1897 land bill to the Secretary of State and Queen in Britain. Their grievances centered on the questions of unoccupied lands and their new status under this bill, chiefly powers and concessions matters. When the ARPS representatives visited the Secretary of State in Britain it was unanimously agreed that native lands would be given out for public purposes when the need arises, but the traditional land tenure system will remain intact, and so this bill was retracted (Kimble, 1963). This gives us just a glimpse of how land was fluid at that time. This disputation over land matters by the chiefs and colonist will further restructure how land is distributed and managed in this contemporary era.

When the British pronounced the Northern territories a protectorate, they did not want a repeat of the land disputes they faced in the South. The wanted to control land speculation and what they referred to as "bad administration" of stool land. The fear of land challenges spilling into the North lead to the Rights and Native Land Ordinance, in 1927. This act stated that all land, occupied or unoccupied, will be vested in the Governor (Lund, 2008a). In addition, these native lands were to be held and administered for use directly or indirectly for the common benefit of the natives and compensations will be paid by the colonial government to the land owners for the utilisation of these lands. This ordinance reflected Governor Maxwell's response to the Southern elites when he was defending the land bill of 1987, where he said of the land bill:

It distinguishes between public rights and private rights. It recognises the fact that the stool lands of a tribe are really public lands which ought to be administered for the benefit of the people...to see that native chiefs do not abuse their position, and exceed their powers, by encroaching upon the rights of those for whom they are really trustees, and by dealing illegally and improvidently with stool lands, which are...the public lands of the tribe. 
His response has been challenged by Amanor (2007), Berry (1992) and ObengOdoom (2014) who argue that the land bills were a colonial construct to have direct control over land, in order to lease it to European entrepreneurs, especially the European bourgeoisies in the colony for their economic endeavours. They argue that the traditional elites and Europeans invented traditional land laws to foster their economic gains through a gradual process of land alienation. This assertion is supported by the work of Quarcoopome (1992) when he stated that almost all lands under the Ga people in Accra were alienated as a result of land sales to government, firms, and private individuals on a freehold basis in 1945 . The Ga State Reformation Association (GSRA), in a bid to salvage the situation, wrote a report stating that if land sales were not put in check, the next generation would not have rights to land. This led to the 1951 leasehold ordinance, where lands could be leased for certain years according to an agreement between the lessor and lessee with payments done in installments to keep land under indigenous control.

In the Northern Territories all lands had been vested in the Governor, who acted as a trustee of the lands for the people. In practical terms, administration and control of land were still significantly in the hands of the chief, through whom the colonist indirectly administered and controlled lands. According to Kasanga (2002), most of the chiefs in the Northern territories were illiterate and did not understand the new land law enacted by the Crown. In addition, few lands were acquired by the government for public purposes, so the chiefs were left to administer the majority of communal lands not used directly by the Crown.

Chiefs through the indirect rule system were considered more as government workers under the control of the colonial government. For example, if chiefs did not adhere to the rules and regulations laid down by the District commissioners they were taken out of office and other chiefs were appointed to take over their positions. This is confirmed in a correspondence written on $9^{\text {th }}$ June 1937 from the District Commissioner to the Chief Commissioner of Northern Territories, stating that he had just appointed two new chiefs. This shows that even though chiefs were traditionally the custodians of land, they could only maintain this position by adhering to rules and regulations imposed by the colonial government. They could easily lose power and authority over land matters depending on their conduct or relation with the colonial government.

Even though the chiefs owned land it was controlled by the colonial government through them. The relationship between chiefs and the colonists has continually changed over time from one of colonists supporting chiefs' control in land matters, to curtailing chiefs' power over land, to colonial attempts at appropriating land, to an uneasy sometimes combined control over land with chiefs. For example, the 1878 Native Jurisdiction Ordinance gave chiefs jurisdictive power to write out bylaws, administer land and forest, and place landmarks and even fences to differentiate land use. When this ordinance was re-enacted in 1883 the power 
of tchiefs was curtailed and all land matters to be carried out by the chiefs had to be approved by the Governor (Addo-Fening, 1990). The lands bills of 1884 and 1887, which was petitioned against by the chiefs in the South, was an attempt by the colonist to take over complete control of land matters from the chiefs. The re-enacted Land and Native Rights Ordinance on the Northern territories in 1931 (No.8) had as objectives stated by Governor Alexander Slater in (Appiah, 2012):

To preclude the natives from the temptation to dispose of their lands outright, with regard for the requirements of their descendants, and for totally inadequate payment; to ensure that such profits as are derived from the land are used for the benefit of the community as a whole and not of any particular section or individual member of it; and to minimize the possibility of ruinous litigation (Legislative Council, 1 March, 1932 (Metcalfe, No. 478)).

Most of the reasons given above for the new law curtailing the power of the chiefs to administer land was a guise by the colonial administrators to have control over private land for economic activities as practiced in the Gold Coast (Southern region of Ghana). The twist introduced by the colonist was that land would remain a property of the people but under control of the Governor. This law created a space within which vague and exploitative leases could be acquired by the colonist. An example of such exploits is Captain Duncan 100 years lease. This acquisition was through the use of an English conveyancing form through which he acquired exclusive rights to:

All the lands of the lessors... and all the adjacent and intermediate villages and the rivers... and all the adjacent streams and mountains together with the right of the lessors in all rivers and water courses in the said lands with all metal ores and minerals, precious stones, rocks or mineral substances or materials within or over and under the said land with full power, license and authority to sink, make and use any shafts... and other mining works now existing or hereinafter to be constructed and carry away and make mercantile all such metals, ores and metallic minerals of any kind and convert the same to the use of the said lessees and for the purpose aforesaid to....build houses or any other building upon the said lands (Agbosu, 2000: 19). 
The above example is one of the effects of the introduction of English contract laws and the unquestioning reception of Anglo-American tenurial concepts and its increasing use in land transactions under the traditional scheme. It should be clear that the reason for these laws was not to secure lands for all, but it was to secure lands acquired by European entrepreneurs for their farming and mining activities in the South (ibid). Here we see a co-construction of land administration and governance by chiefs and colonialists to suit their various interests and agendas, thus reshaping land use patterns.

This section has demonstrated that in the Gold Coast and the Northern Territories the position of the colonial powers in supporting chiefs to administer lands was continually shifting according to their different interests and these power shifts changed land use patterns and reshaped property rights. The colonial administration instituted laws and ordinances to curtail chiefs' control over land. Land agencies like the Survey Department and the Lands Department were also put in place to facilitate land titles for colonial landowners and compulsory acquisition of land for public infrastructural development (Kasanga, 2002). The relationship between chiefs and colonial authorities shifted from indirect control of land to appropriation of land as explained above. Colonial appropriation of land, especially in the Northern territories, laid down the foundation for a contested post-independence public administration of land. Prior to 1979 , all lands were subject to the Lands Commission, where compensations were not paid for lands taken for public services. After the 1979 Constitution lands were reverted back to the 'original land owners.' In the Northern region, intertribal wars resulted between the Dagombas and the Kokombas on whom was the original landowner explained in Pul (2003).

This also led to the reconstruction of landed property rights especially in the Upper East region where there existed acute contestation between chiefs and earth priest over land administration and control as discussed in Lund (2008b). The next section will discuss how the existence of a dual land tenure system was solidified and why it still exists today in the Ghanaian society. This begins by examining the difference techniques used by both colonial government and chiefs to continue administering customary lands and created public lands. I will explain how these actors in negotiating their control over land have reconstructed property rights and access to resources such as land.

\subsection{A dual land tenure system}

Due to the increasing economic activities in the Coastal areas by European and local businessmen it became the starting point of a contested land administrative system where the colonist put in place laws to facilitate access to land for their entrepreneurs while the chiefs petitioned some of these laws to maintain control over land. A concretised dual land administrative system was created as a result of a unified governmental system born from a separate native and colonial administrative system. I will examine how this system was set into motion 
by the colonial government in the Gold Coast and how it led to changes in the Northern Territories and later the contemporary Ghanaian land tenure system as a whole.

The concretising evidence of a dual system of land tenure in the Gold Coast started with a banquet organised by the Gold Coast Aborigines' Rights Protection Society (ARPS) for the new Governor, Sir Hugh Clifford on the $26^{\text {th }}$ of December 1912, just five months after his arrival. The ARPS was the political backbone of the traditional rulers who fought for retaining the customary land tenure system during the proposed 1894 and 1897 land bills. This banquet was a reminder to the colonial government of the promise from Mr. Chamberlain that native land would remain in native hands. The new Governor, according to J. E. Casely Hayford's speech at the Aborigines banquet in honour of Governor Hugh Clifford on $19^{\text {th }}$ May 1913, chose the path of cooperation. This event marked a change of colonial administration of native land from a position of state appropriation of land in the 1890s to supporting the chiefs in their management of a traditional land tenure system in the $20^{\text {th }}$ century.

Appiah (2012) advanced, many political and economic reasons for the change in colonial land policy. The traditional system in place had the capacity to promote indigenous and European capitalist growth which met the economic interest of the European and increased domestic capital for the native entrepreneurs. The chiefs and educated elites were willing to cooperate with the colonial government if their communal land tenure system was maintained and not threatened. The colonial government was more concerned that the land tenure system in place might constrain their economic interest in acquiring lands for agriculture and mining especially with the economic boom at the time, which was leading to indiscriminate land alienation.

The colonial government needed political support from chiefs and non-chief elites (educated Africans like members of the ARPS) in their pursuit of indirect administration in state building. Since the chiefs were under their control, they were like easy tools with which they could govern the people. This was a relationship of convenience for the colonial authorities who used the chiefs to attain their economic interest which was extracting raw materials for their country back home. They also needed the support of the non-chiefs' groups like the Gold Coast Aborigines' Rights Protection Society due to their political and economic influence in the community. For example, non-chief elites were very influential in thwarting the land bill in 1884 and 1887 and pursuing other bills considered detrimental to the indigenes.

The chiefs mobilised money for local development or provided free manual labour in the different regions. For example, during the invasion of locust, the chiefs had as their directives to get local people to kill these insects and also to provide free manual labour for road constructions in exchange for food on the 'work and food programme' in the North. Chiefs also provided voluntary labour for construction of government buildings, such as was the case in Tamale where government buildings were constructed for about a year, during which time 
failure to provide this free labour came with fines or flogging of chiefs. Money collected from chiefs contributed significantly to the relief measures instituted during the era of locust invasion. Money mobilised by the chiefs for development on the Gold Coast was also used in subsidising administration cost in the North.

I have shown above that the British colonial government encountered obstacles from the chiefs and non-chief elites in the appropriation of land, but later cooperated with them to have access to land under native authority as prescribed by the ARPS in their agreement with British authorities after the 1984 and 1897 land bill petition. Furthermore, to maintain a firm grip on land affairs, the colonial authorities later made the chiefs the main agents of local administration, through whom they could access resources, including land, and sideline the non-chief elites. This tactic of divide and rule policy led to antagonism between the chiefs and non-chief elites, enabling the colonial authorities to promote their interests without interference from the local elites.

In the Northern Territories, the colonial governmen,t not wanting a repeat of the resistance to land acquisition that they experienced after the 1884 and 1897 land bills in the Gold Coast colony, decided to vest all lands in the Northern Territories in the Crown through several Acts ${ }^{17}$. This means that colonial land policy in the Southern and Northern parts of Ghana was different. These changes in land policy have influenced the present land tenure systems in these separate regions and property rights in contemporary Ghana.

The change of land policy by the colonial government in the Gold Coast colony could be seen as a political trade-off that enables the British government to continually control and administer land with the support of the chiefs, whose position was legitimised by the colonialist. This permitted the integration of chiefs into their rule in the Gold Coast from 1916 to 1953, and a quest to turn the chieftaincy organisations into an accountable agency of land administration through which they could easily access land (Adu-Boahen, 2000). This was achievable through, the consolidation of the stool/skin land system, whereby the land tenure system was reconstructed by the chiefs, colonialist, and local merchant to achieve their interests and agenda at the time, which was mostly economic gain (Berry, 1989).

The reinvention of traditional land laws was possible as chiefs, considered to be traditional experts on customary land laws, pushed their agenda of maintaining access to land as allodial land owners. They were supported by local merchants who also had their agenda of acquiring lands through the chiefs for commercial farming and mining in competition with their European counterparts. The chiefs got power and authority over lands and people from the colonial administration and in exchange gave them access to resources including land. The

\footnotetext{
17 Northern Territories Ordinance (CAPIII) of 1902, Land and Native Right Ordinance (No. 1) 1927, Land and Native Right Ordinance of November 21 ${ }^{\text {st }}$ (CAP 147) revised in 1951. Mineral Ordinance 1936 (CAP 155) revised in 1951.
} 
colonialists contributed to this process by legitimising chiefs as local authorities over land resources but at the same time introduced land laws which made access to these resources easy for them.

Land administration was in the hands of colonialists and chiefs. Chiefs with the support of the colonial government sold out lands and gave a certain percentage to the colonial administration for the development of the colony and in return gained excess power and authority over their people with colonial support. Chiefs were selected not out of nobility, but rather as a result of their ability to provide revenue for colonial activities. Most of these chiefs were referred to as 'warrant chiefs' and were very influential, as their activities were backed by the colonial government. Compulsory acquisition of land for public services was made possible through the creation of the Survey Department in 1909 and the Land Department in the 1920's.

The colonial government decided to opt for a unified system of government in order to maintain complete control over chiefs and the resources under their control. In this proposed system of power, chiefs were integrated into the decision-making body of the government which is the legislative and executive body of the ruling coalition. The Executive Council was initially a small advisory body of European officials that recommended laws and voted taxes, subject to the governor's approval. The Legislative Council included the members of the Executive Council and unofficial members initially chosen from British commercial interests group. Unofficial members were members who were not part of the colonial government. The Legislative Council played an advisory role to the Governor, who exercised legislative and executive powers. Governor Clifford and other subsequent Governors like Gordon Guggisberg said the reason for the integration of chiefs into high-level state affairs was because chiefs already had intimate knowledge and first class experience in ruling their people.

By allowing local rulers to exercise direct administrative control over their people, opposition to European rule from the local population was minimised and the powers of chiefs enhanced. For example, the colonial government, by limiting nominations into the legislative assembly to chiefs, drove a wedge between chiefs and their educated subjects (non-chiefs). By 1925 the number of chiefs in the legislative council increased, as seen in Table 5.1 and the chiefs were encouraged to form the provincial council for chiefs which later became the Regional House of Chiefs. The educated subjects (local elites) believed that the chiefs, in return for British support, had allowed the provincial councils to fall completely under the control of the colonial government.

At this time chief in the Northern Territories were not included in the legislative council so they were charged to provide the needed labour force for development projects in the Gold Coast--construction of the railway link and the deep water harbours in Tema and Takoradi. The council was made up of chiefs only from Accra, Cape Coast, and Sekondi, who were 
asked in a democratic move to elect six chiefs who would be unofficial members of the Legislative Council. Naylor (2000) refers to this move as one of interest for the British and not one which promoted democracy.

The legislative and executive council played an advisory role to the governors on state affairs until 1942 when their roles changed significantly to statutory and executive.

Table 5.1: Incorporation of Chiefs and Non-Chiefs into the Legislative Council

\begin{tabular}{|l|l|l|l|l|l|}
\hline \multirow{2}{*}{$\begin{array}{l}\text { Date of re- } \\
\text { form }\end{array}$} & \multicolumn{2}{|l|}{ Ghanaian representatives } & \multicolumn{2}{l|}{ European representatives } & Total \\
\cline { 2 - 5 } & Chiefs & $\begin{array}{l}\text { Non- } \\
\text { chiefs }\end{array}$ & $\begin{array}{l}\text { Official } \\
\text { Members }\end{array}$ & $\begin{array}{l}\text { Unofficial } \\
\text { members }\end{array}$ & \\
\hline 1915 & 1 & 1 & 5 & 2 & 9 \\
\hline 1916 & 3 & 3 & 11 & 3 & 20 \\
\hline 1926 & 6 & 3 & 16 & 5 & 30 \\
\hline 1946 & 13 & 5 & 7 & 6 & 31 \\
\hline 1951 & 17 & 58 & 5 & & 104 \\
\hline 1954 & 0 & 104 & 0 & & 80 \\
\hline
\end{tabular}

Source: Appiah, 2012

Table 5.2: Incorporation of Chiefs and Non-Chiefs into the Executive Council

\begin{tabular}{|c|c|c|c|c|c|}
\hline \multirow[t]{2}{*}{$\begin{array}{l}\text { Date of re- } \\
\text { form }\end{array}$} & \multicolumn{2}{|c|}{$\begin{array}{l}\text { Ghanaian representa- } \\
\text { tives }\end{array}$} & \multicolumn{2}{|c|}{ European representatives } & \multirow[t]{2}{*}{ Total } \\
\hline & Chiefs & $\begin{array}{l}\text { Non- } \\
\text { chiefs }\end{array}$ & $\begin{array}{l}\text { Official mem- } \\
\text { bers }\end{array}$ & $\begin{array}{l}\text { Unofficial } \\
\text { Members }\end{array}$ & \\
\hline 1915 & 0 & 0 & 5 & 0 & 5 \\
\hline 1916 & 0 & 0 & 5 & 0 & 5 \\
\hline 1926 & 0 & 0 & 5 & 0 & 5 \\
\hline 1946 & 1 & 1 & 5 & 0 & 7 \\
\hline 1951 & 0 & 8 & 4 & 0 & 12 \\
\hline 1954 & 0 & 11 & 1 & 0 & 12 \\
\hline
\end{tabular}

Source: Appiah, 2012

In 1942 Ghana took the lead amongst all British colonies in Africa and the Caribbean when, in response to incessant demands made by the people, the governor, Sir Alan Burns, 
appointed two distinguished Ghanaians to serve on the executive council. One was a traditional ruler, Nana Sir Ofori Atta I, a paramount chief of Akyem Abuakwa; the other, unofficial, member was a leading lawyer, Sir Arku Korsah who had both served in the legislative council. In spite of this innovation, the people did not gain real effective participation on the executive council until 1951 as shown in Table 5.2.

The colonial Gold Coast was subject to a binary legal system as already explained above. The majority of criminal and civil matters which affected Africans were dealt with in the Native Courts. These courts were run in accordance with what was understood to be customary law and were presided over by chiefs and their councillors. From the 1930's this system was widely agreed to be an inefficient and an often unfair justice system. The chiefs exploited the people for personal gains by exchanging justice for money. The colonial authority shied away from attempting any reforms on this system due to personal economic and social gains, but over time they became alarmed by the perceived corruption evident in these tribunals. In most cases "Customary law was defined, interpreted and in some cases invented by Native Authorities and in Native Courts; it thus varied considerably from area to area, as well as over time" (Rathbone, 2000a: 126).

Even though the colonial authorities were aware of the corrupt and anachronistic attitudes of the chiefs, reforming the system was difficult because they relied on the local agency of the chiefs to function effectively, and alienating their allies was considered risky. According to Rathbone (2000a: 127) the colonial government and the chiefs had each settled into "informally demarcated zones of non-intervention" where each actor had morally inscribed "no-go areas.' This arrangement between the chiefs and the colonial government built the defences of the chiefs against the educated subjects who were considered unqualified to represent the people, as 'custom' denied that possibility. In addition, a weak colonial regime throughout the interwar period lacked the will and the resources to reform both the local court system and the local government system. Authorities and Native Courts maintained the capacity to pass and then use by-laws which were occasionally oppressive, and often did so even in the face of the censure of the central government.

Long overdue reforms began especially after the publishing of the Blackall committee report of an inquiry into the Native Administrative system. This report presented the chiefs and their councilors as ineffective and corrupt in the ways that they exercised authority over legal matters pertaining to land and taxes among others. The Blackall report was the catalyst for a radical change in chieftaincy administration in 1944 (Appiah, 2012). The chiefs did not resist the coming reforms like the Native Authority Ordinance and Native Courts Ordinance, as confirmed in Nana Ofori Atta Legislative Council debate in 1943 when he stated the positions of the chiefs as: 
Provided there is nothing which is in direct conflict with some of the fundamental principles of the native constitution, we will co-operate with Your Excellency in bringing up any measure which in the judgement of the Government will help to smoothen the administration of this country.

In 1944, the Legislative Council passed the Native Authorities Ordinance and the Native Courts Ordinance. This led to the formation of three local government administrations; the Native Authority, the State Council, and the Native Courts. The government appointed those they thought capable as Native Authorities with responsibilities including the maintenance of a treasury, police, prisons, native courts, health facilities, and schools. The state council declared customary laws which dealt with the installation and deposition of chiefs, recovery of stool lands, all of which needed to be approved by the Governor. The Native Court Ordinance transformed the Native Tribunals into modern Native courts (Rathbone, 2000b). After the Native Authority Ordinance was passed 95 Native Authorities were created with treasuries- 48 in the Colony, 35 in Ashanti, and 12 in the Northern Territory. Today, the functions of Traditional Councils remain almost the same as they were in 1944, with the only slight change being that the declaration of customary laws now passes through a lengthy procedure involving the National House of Chiefs, Parliament and the President (Appiah, 2012).

The preamble of the Native Court Ordinance stressed that "it is expedient that ... provision be now made whereby ... chiefs may be enabled to take effective part in the administration of the Colony" makes the 1944 reforms unique. (Rathbone, 2000b: 17). The intention was to curb the independent role of the chiefs and give chiefs centrally defined roles under the control of the government. Appiah (2012) refers to this process of integrating chiefs into the central government as a unitary state organisational framework, which in practice meant that all chiefs were appointed by the Governor as Native Authorities (Hailey, 1956). This is to say, chiefs were regarded as government officials who could be removed from their positions for not carrying out their duties well. They lost their identity as traditional statesmen and now needed complete legitimacy from the state in order to reign over their subjects (Staniland, 1975). Ward (1958: 363) captured the effect of the 1944 Native Administration Ordinance as follows:

The Ordinance abandoned the old conception of the central Government and the native authorities as two separate powers, which might co-operate but need not. It replaced this by a new conception: both central Government and native authorities were parts of one unified Governmental system. 
The chiefs defended their integration into the colonial government system as opposed to the non-chiefly elites. In the words of Nana Ofori Atta "an ounce of experience is better than a ton of theory." (legislative council meeting on $18^{\text {th }}$ March 1926). Notwithstanding, the political progress made by the colonial government in reforming chieftaincy administration, was considered insufficient by the non-chiefly elites who later took over complete control of the Executive and Legislative Councils in 1951. The catalyst for this change lies in the aftermath of the urban riots in 1948 in the Gold Coast. This riot started after war veterans were killed when requesting their pensions. The Big Six (J.B Danquah, Kwame Nkrumah, Obetsebi Lamptey, Akuffo Addo, William Ofori Atta and Ako Adjei) were accused by the colonial government of inciting this riot and were jailed. The Watson Commission was formed to investigate the reason for the 1948 riots. In their report, the Big Six's grievances against the colonial government rule over the people were stated, and the need for greater control of the state by the people expressed. This report also criticised the chiefs harshly and stated categorically that:

An intense suspicion that the Chiefs are being used by the Government as an instrument for the delay if not the suppression of the political aspirations of the people... The view is advanced that as long as the Chiefs accepts and supports the Government policy he will receive Government support however much he become the object of dislike of the people (Watson Commission Report, paragraph 104 and 107).

They concluded by stating that "chiefly rule was dying on its feet" (Rathbone, 2000b: 19). The Senior Colonial Officer criticised this report. He said the report was framed by jealousy and vested interest of the commission members against the chiefs. He said the report was prejudiced, and that the educated elites did not acknowledge the difficulty of creating a new and modern government from the existing traditional system (PRO CO 96/796/5, Minute, $29^{\text {th }}$ June 1948).

The Watson Commission recommended the creation of a representative constitution by an all-African committee to draft a constitution to replace the 1946 constitution. This committee was appointed under the leadership of a Ghanaian Judge, Sir Henley Coussey. It was made up of some senior chiefs, amongst other members, so that their treatment of the traditional chiefs was gentler than the treatment of the chiefs by the Watson Commission. This allAfrican committee came to be known as the Coussey Committee. They designed a new sys- 
tem of local government where Native Authorities were replaced by Local Councils. This relegated the duties of chiefs to dealing with stool disputes related to customary laws, a marginal role of which the Watson Commission had made reference to.

Kwame Nkrumah, one of the educated elites who despised the dominance of the chiefs in the colonial council, became the leader of the Convention People's Party (CPP) movement by 1949 and in their editorial paper, Accra Evening News, wrote:

Those chiefs who are with us... we do honour... those... who join forces with the imperialist... there shall come a time when they will run away fast and leave their sandals behind them; in other words Chiefs in league with imperialists who obstruct our path... will one day run away and leave their stools (Rathbone, 2000b: 22).

The words of Nkrumah have been assumed to be targeted at some chiefs who openly opposed the CPP and sided with the United Gold Coast Convention (UGCC) from which the CPP split. For example, it was alleged that Naa Yiri from the Northern Territories attempted to pull down the CPP branch in Tamale (Rathbone, 2000b). This rivalry further widened the gap between the chiefs and the nationalist elites. In 1951 there existed 58 non-chief seats comprised of 33 Rural Electoral Colleges, 5 Municipal Councils, 19 Northern Electoral Colleges and the Southern Togoland Council (Austin, 1964). The specially constructed Northern Electoral College was made up of members from the Northern Territories Council and existing native authorities (Austin, 1964). The 19 members of the Northern Electoral College (NEC) included at least four chiefs - namely, the Kabachewura, the Wa-naa, the Tali-naa and the Katua-naa - this is not surprising as in the North, the sons of chiefs had the privilege to go to school compared to commoners (Austin, 1964; Weiss, 2004).

According to Rathbone (2000b), the non-chiefs described the chiefs as traditional ornaments less equipped to handle their positions within the different councils compared to them. As the non-chiefs increased in number, they formed a majority in these councils and demanded that positions in the Legislative Committee be electoral, giving them an opportunity to have greater control over colonial government activities. By 1951 the non-chiefs had overtaken the chiefs in their advisory role in the state.

In this section, I have explained how the colonial government, through conflictual and cooperative relations with chiefs and educated elites, was able to create a unified government from a separate colonial and native authority rule. This was done through indirect rule, where the resources were accessed through chiefs, and in some cases "divide and rule," by which relations between chiefs and the local elites were strained, giving colonial government opportunities to access the necessary resources for their socio-economic and political interests. 
These strategies were used in all British Colonies in West Africa, and even in the Caribbean, to control the people and tap into their resources for socio-economic gain and socio-political power in Europe and the rest of the world. In my study site all actors (chiefs, government, civil societies and farmers), in their quest to gain access and control over land, negotiate in conflicting situations and also cooperate to attain their interests, as discussed in Chapters 6 and 7. In the next section I will examine how lands are administered by different actors and which strands of law or historical discourse said actors use to legitimise their claim to land.

\subsection{Post-independence land tenure system}

After independence, many land management reforms were put into place, especially from 1957 to 1968. These reforms were the State Land Act, 1962 (Act 125), the Administration Lands Act of 1962 (Act 123) and the State Property and Contracts Act 1960 (CA6). These Acts changed the land tenure administration system in Southern and Northern Ghana. These Acts were meant to shift control of land from the colonial system to the present government and monetise all lands through titling (Kasanga andKotey, 2001). Land in the North was transferred from the control of the Crown to the Government, while some stool lands in Southern Ghana were vested in the government (Kasanga, 2002). These reforms aimed to affect equity and equal rights to land for all.

Obeng-Odoom (2014) states that the idea of the 'untouchable chief 'and his land, misconstrued as communal land, was not eroded or erased after independence, as explained above. Even though Nkrumah (1973: 35) said, “...the government believes that chieftaincy, in common with other human institutions, cannot remain static, but that it must in large measure adapt itself to the changing requirement of the changing time," the only change witnessed was a shift in the power of managing and controlling land from the chieftaincy institution to the state, through acts such as the Ashanti Stool Land Act of 1958, the Akim Abuakwa (Stool Revenue) Act 78 of 1958, the State Lands Act, 1962 (Act 125) and the Administration of Lands Act of 1962 (Act 123). The changes in land ownership from the chiefs to the state, especially in the South, had limited structural effects as the chiefs still benefited from land revenue even though land was managed by the state. Here one can see a shift of power from one actor group to another, which is not very different from the system which existed during the colonial era, where the colonist controlled land indirectly through the chiefs and later jointly, to exploit land and other resources.

Much early research on the dominant liberal and Marxist paradigms of the 1960's and 70's portrays colonial states as external actors governing and exploiting African societies in accordance with their political and economic interests back home (Berry, 1992). Other authors like Bates (1983), Berry (1992) and Jessop (1977) have argued that states should simply be considered as complex institutions which are made up of individuals or a group of individuals 
with different interests and links to the societies they seek to govern. Thus, political institutions can be considered as a market through which individuals channel their preferences for a social outcome. For example, local businessmen and chiefs negotiated with the colonial government to reinvent tradition to meet their economic interests and simultaneously gain legitimacy over resources and the people. It is also true that the colonial government used the chieftaincy institution as a tool to subdue the masses, especially the educated elites, and to gain access to resources like land and labour for their socio-economic gains.

Even though the government manages national economies, they can only retain power through satisfying the interests of other key sectors within the domestic political economy through whom they gain legitimacy. After Nkrumah was overthrown the land tenure system underwent various reforms. In 1978 lands vested in the state was reverted back to the original owners, and the 1992 constitution consolidated this shift in land administration (Kasanga, 2002). There exist 86 legal instruments ${ }^{18}$ alongside customary laws (Ministry of Land and Forestry, 2003a) creating overlapps and conflicts, regarding ownership and administration of land. Kotey et al. (2004) in their final report on a judicial and legislative review of the Land Administration Project pointed out that it is difficult to reconcile the notion of families, stool, and individuals owning with managing land.

Chieftaincy institution was established according to customary laws, where chiefs are expected to manage and administer lands in the interest of the community. Presently chiefs are 'selling land' for personal gain with no regard for community development or welfare according to interviews with farmers. More data regarding this issue can be found in Chapters 6 and 7. Chiefs have defended themselves, stating that their position comes with many financial responsibilities, such as supporting the needy that come to the palace for aid, representing the community's interest in different forums and a general upkeep of the chieftaincy office (Interview with the chief of Malshegu, 2014). The money needed to take care of all the listed financial responsibilities can be gotten only from 'selling' land, which they have control over as they do not receive any salary from the state. The $25 \%$ from stool/skin land sales is too small and petty to cover chiefly functions. Traditional institutions (Traditional Councils, Regional Houses of Chiefs, and National House of Chiefs) and the created public agencies of land administration like the Lands Commission and the Office of Stool Land Administration are always in conflict over the administration of stool/skin land. I agree with Appiah, (2012)

\footnotetext{
18 Local Government Act 1993(Act 462); Town and Country Planning Ordinance of 1945(CAP 84); Fourth Republic Constitution of the Republic of Ghana, 1992; Administration of Stool Lands Act, 1994(Act 481) which repealed the Administration of Stool Lands Act 1962(Act123); State Lands Act, 1962 (Act125); Deeds Registration Ordinance of 1883; Land Registry Ordinance of 1895; Land Registry Act 1962(Act 122); Land Title Registration Law, 186 (PNDCL 152); Land Title Regulation, 1986 Legislative instrument(L.I) 1241; National Development Planning Commission Act 1994(Act 479); National Development Planning (Systems) Act 1994(Act 480); Land Commission Act, 2008(Act 767) which repealed the Lands Commission Act 2000(Act 483).
} 
that these conflicts exist because the authority or duty of a chief has not been clearly outlined in the constitution or in any legislative enactment.

Examples of conflicts and overlaps in administering stool/skin land include Article 271(1) of the 1992 constitution which states that "all stool land is vested in the appropriate stool or skin on behalf of and in trust for the subjects of the stool or skin in accordance with the customary law and usage." This implies that the traditional authorities have the right to take management decisions and exercise powers on who can own land, how land is sold, who receives proceeds from these sales and also allocation terms and prices for a plot. However, Article 267(2) instituted the Office of the Administration of Stool Land which is supposed to work on disbursement of all stool/skin land revenues including rents and royalties. The traditional authority receives only $25 \%$, the traditional council $20 \%$ and the State a significant share of $55 \%$, as per Article $267(6)$ in the same constitution.

In Article 267(3) no stool land can be developed except when it is authorised by the Regional Land Commission, and only then if it is consistent with the development plan drawn by the Town and Country Planning Department for the said area. This implies that where the Lands Commission is unable to accord any development activity carried out is considered illegal and therefore not formally recognised. In article 267(1) all stool/skin lands are vested in the chiefs on behalf of and in trust for the subjects of the stool in accordance with customary law and usage. This implies that chiefs have control over lands and can allocate them to estate developers without permission from the Land Commission.

The creation of the Land Title Registry did not take into account the already existing deeds registry. The new process of registering land titles, which is practiced only in Accra, Greater Accra and some part of Kumasi, has become a complex mix that involves public land agencies like the Land Title Registry, the Lands Commission, the Survey Department and the Land Valuation Board. During a land title registration process:

The Survey Department is required to prepare a parcel/cadastral plan which is recorded in the records of the Survey Department and the Land Title Registry to prevent multiple registration. The plan is vital to the whole process. Until an applicant's plan is received from the Survey Department, publication cannot be placed in the newspaper, a search cannot be conducted at the Lands Commission and there can be no spatial description in the Land certificate to be issued (Sittie, 2006: 5).

If this process is strictly followed, as described by the head of the land registry department in Accra, then land title duplications will be avoided. This process of acquiring a land title 
is problematic for those who have a deed title and want to lease it out to another person under the new land titling system. The problem is that land titles cannot be contested only in the case of fraud, unlike the deed titles which can be challenged at any time. Obtaining a land title usually involves the following process detailed in Figure 5.1.

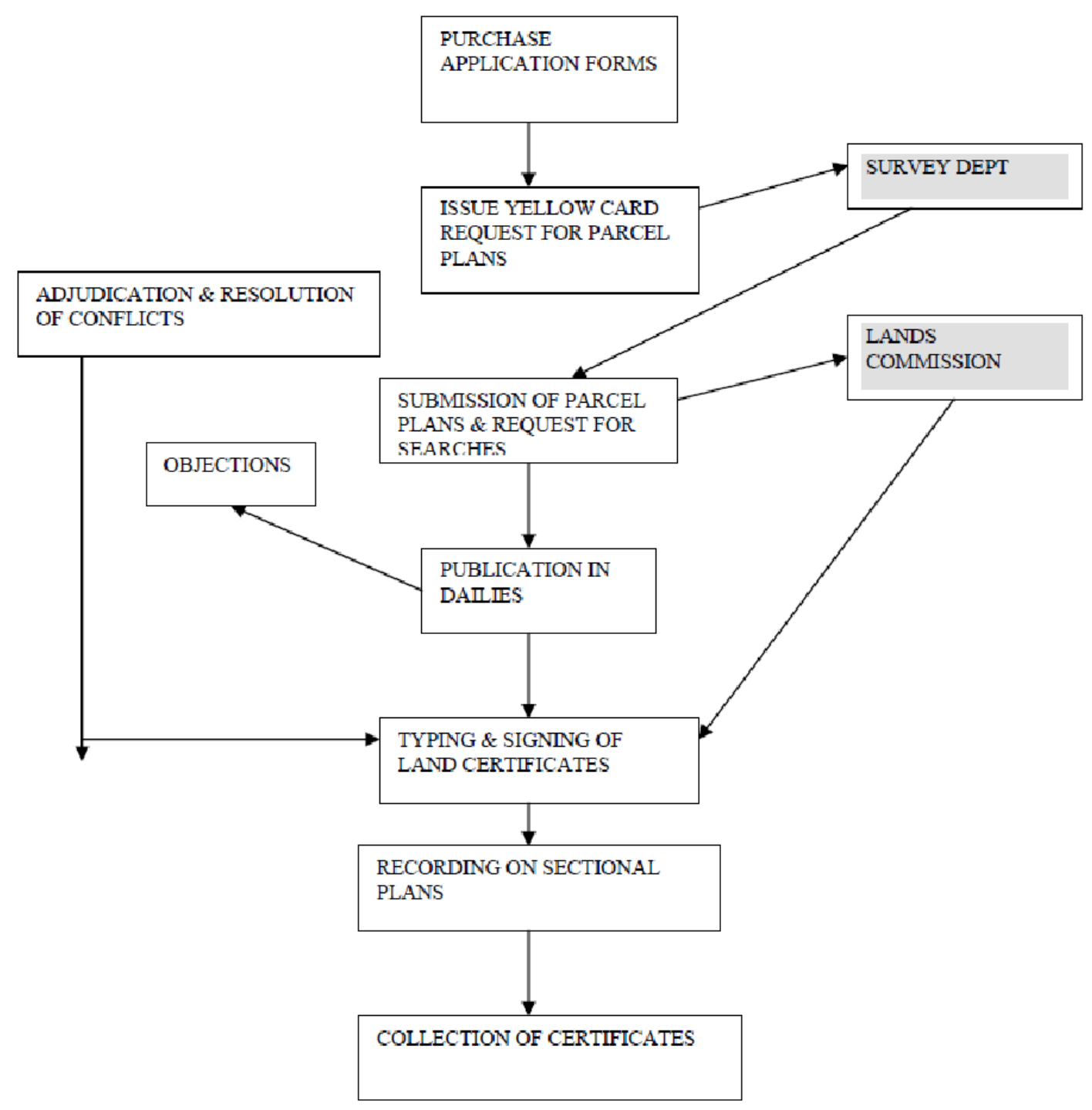

Figure 5.1: Procedure for securing a land title in Accra, Greater Accra and part of Kumasi

Source: Sittie, 2006

The Land Title Registration Law was implemented in Accra and Kumasi after a pilot study was carried out in 1991 and 1999 sponsored by the World Bank. It took place in two urban cities in Ghana - Accra and Kumasi. Even though this pilot study was considered a success by the government of Ghana and the World Bank, this system of gaining title to land 
was introduced only in Accra, Greater Accra, and parts of Kumasi. The old deed system of getting a lease to land is practiced in the rest of the country. Another problem inherent in the land administration sector in Ghana is overlaps within the government land agencies. Overlaps could be seen in legal services provision between the Land Valuation Board, a sub-department under the Land Commission charged with assessing compensation payable for public land acquired by the government, determining the values of properties rented or sold by the government, etc. and the Land commission. The Land Valuation board had no legal staff to attend to the many land claims of over US $\$ 110 \mathrm{~m}$ which flooded its corridors. They solicited the services of legal staff from the Lands Commission and Attorney General's Department through informal negotiations, which were not always efficient due to lack of incentives or any legislative body to mediate this cooperation (Kasanga andKotey, 2001).

In sum, there exist overlaps in land administration and management not only between the chieftaincy institution and government land agencies but also between the land agencies themselves. These overlaps still exist and create spaces through which actors like farmers negotiate for access to land for vegetable gardening, as explained in Chapters 6 and 7. For a more comprehensive understanding of contemporary land tenure system in Ghana, I will explain how the chieftaincy institution redefined the customary land tenure system and why they succeeded. I will also explain how the failure in codifying customary land laws by the government or chiefs has reshaped land administration in present day Ghana.

\subsubsection{Chieftaincy and Stool land administration}

Chieftaincy institutions integrated into the unified colonial system before independence, were the State Councils, the Provincial Councils and the Joint Provincial Councils of chiefs. Today these councils, largely innovated through the support of the colonial government, form an integral part of chieftaincy institutions in the present Ghanaian state. The State Councils are now referred to as the Traditional Councils, the Provincial Councils are now called the Regional House of Chiefs, and the Joint Provincial Councils are now called the National House of Chiefs. In the present government structure these institutions exercise judicial, administrative and political statutory functions which I will discuss below. The only difference in their duties between now and the colonial era is that they no longer elect representatives to parliament, nor are the chiefs permitted to hold any government office.

According to the Chieftaincy Act of 2008 (Act 759), the formal chieftaincy councils have jurisdiction authority to hear and determine chieftaincy matters at community and national levels. For example, the Regional House of Chiefs hears and determines chieftaincy matters in adherence to Article 274 of the 1992 Constitution. The National House of Chiefs is made up of five paramount chiefs elected from the different Regional Houses of Chiefs, and they are represented on the governing board of the Lands Commission in line with Article 259 of the 
1992 constitution. The president of the National House of Chiefs is an automatic ex-officio member and so contributes to decisions on policy change instituted by the Presidential-Executive found in the Article 89-92, 1992 Constitution.

Due to the historical conflict between the chiefs and non-chiefs (local elites) from the colonial era on stool/skin land administration and state control, Article 270 (2-3) of the 1992 Constitution resolves this issue when it states clearly that:

(2) Parliament shall have no power to enact any law which (a) confers on any person or authority the right to accord or withdraw recognition to or from a chief for any purpose whatsoever; or (b) in any way detracts or derogates from the honour and dignity of the institution of chieftaincy. (3) Nothing in or done under the authority of any law shall be held to be inconsistent with, or in contravention of, clause (1) or (2) of this article if the law makes provision for- (a) the determination, in accordance with the appropriate customary law and usage, by a traditional council, a Regional House of Chiefs or a Chieftaincy Committee of any of them, of the validity of the nomination, election, selection, installation or deposition of a person as a chief; (b) a traditional council or a Regional House of Chiefs or the National House of Chiefs to establish and operate a procedure for the registration of chiefs and the public notification in the Gazette or otherwise of the status of persons as chiefs in Ghana.

In addition, the authority of the legislature is constrained in Article 106 (3) of the same Constitution, which states that "A bill affecting the institution of chieftaincy shall not be introduced in Parliament without prior reference to the National House of Chiefs." The National House of Chiefs, then, functions as a quasi-legislative in the country. The political implication for this constitutional constraint is that stool land administration cannot be effectively carried out without the cooperation of the chief, for, according to Brobbey (2008: 3), "the constitution takes away the power of the government or parliament to control chiefs." Matters relating to chieftaincy are left in the hands of the chieftaincy councils and can only be referred to the Supreme Court if resolutions cannot be met (Brobbey, 2008). This shows clearly the judicial and statutory powers of the chieftaincy institutions. The powers of the chieftaincy institution 
are re-emphasised in the words of the former Prime Minister Mahama Aliu cited in the Modern Ghana website ${ }^{19}$ during Brobbey's book launch in 2008:

The Constitution appears not to have gone into enough detail about how the institution of chieftaincy is to be preserved and sustained. Beyond specifying that chiefs are to progressively codify oral traditions and lines of succession, the Constitution does not state clearly other functions and is silent on critical issues of accessions to stools and skins, remuneration and accountability.

Chieftaincy institutions have the power and authority to cooperate with or resist government policies to customary land administration. Customary land administration relies on formal and informal customary and state land laws in Ghana. All four of the Constitutions of Ghana $^{20}$ from the different republics make clear the inclusion of the customary laws into the common law of Ghana with specificity to the community involved. That is, "the sources of customary law are as varied as the regions, tribes, and communities in Ghana, and its content is correspondingly diverse" (Blocher, 2006: 178). Ollennu (1971) asserts that the land law of Ghana is the customary law and no other law, because the customary law in land tenure takes precedence over common law. Crook et al. (2007) clearly point out that the foundation for legal pluralism was laid down with the official definition of customary law. In 1960 the Minister of Local government, Mr. Ofori Atta, presented to the constituent assembly a bill that sought to define, amongst others, the elements of customary law. Section 17 (2) of this Interpretation Bill stipulated that rules of customary law already assimilated by the courts will prevail over any informal rule in the case of inconsistency. The Interpretation Bill, which is now the Interpretation Act 1960 (CA 4), was perceived by chiefs as a device of the government to take away their power and authority in making new customary laws or modifying old ones.

Appiah (2012) argues that chiefs have always cleaved to their authority and knowledge on specific rules and their powers to modify them. However, lawyers and judges have also cleaved to their own rules referring to Courts Act 1993 (Act 459) section 55(1), which says "Any question as to existence or content of a rule of customary law is a question of law for the court and not a question of fact." Other subsections of this Act seem to contradict this view, as section $55(2)$ states:

19 https://www.modernghana.com/news/176052/book-on-law-of-chieftaincy-launched.html. Retrieved on the $9^{\text {th }}$ of October, 2016.

${ }^{20}$ Article 40(f) of the 1960 constitution, article 126 (2-3) of the 1969 constitution, article 4 (2-3) of the 1979 constitution and article 11(2-3) of the 1992 constitution. 
If there is doubt as to the existence or content of a rule of customary law relevant in any proceedings before a court, the court may adjourn the proceedings to enable an inquiry to be made under subsection (3) of this section after the court has considered submissions made by or on behalf of the parties and after the court has considered reported cases, textbooks and other sources that may be appropriate to the proceedings.

Also, according to section 55(5): "The court may request a House of Chiefs, Divisional or Traditional Council or another body with knowledge of the customary law in question to state its opinion which may be laid before the inquiry in written form." The above statements reflect a lack of certainty about the rules pertaining to customary laws within the courts. The chieftaincy institution is recognised as the custodian of customary knowledge and laws, but the inconsistency and fluidity of these rules in current times have pushed lawyers and judges to follow the assimilated version of the customary law (Kludze, 1987; Kunbour, 2002).

From the discussion above it is clear that there exist two forms of customary law judicial customary law and practiced customary law. The judicial customary law is assimilated into the courts, while the practiced customary law comes into being through long term usage in the community (Crook et al., 2007). A comprehensive definition of these two types of customary laws has been offered by Kludze (1987: 108):

The practiced customary law consists of the rules of customary law sanctioned by general acceptance and long usage of the general populace of a community and which have crystallised over the years and are binding as rules of law"; and, "The judicial customary law is the body of rules, purportedly rules of 'customary' law, applied by the courts of the regular court system established under the various Courts Ordinances and Courts Acts.

In other words, the judiciary customary laws are informal rules in the community that have been codified and made formal through the courts. The latter are static and preferred by lawyers and judges while the former is always changing in response to the changing socioeconomic and political environment. According to Kludze (1987: 108), many legal scholars have observed that the courts are reluctant to enforce rules from the practiced customary laws even when "the judiciary customary law has often been wrong." Even though the Chieftaincy Act of 2008 has provided a legal procedure through which a customary law considered uncertain or needing modification and assimilation can become a common law, this option is rarely used by legal practitioners. 
The procedure for changing a customary law into common law starts from the Traditional Council of chiefs drafting its opinion on the customary rule and presenting it to the Regional House of Chiefs. The Regional House of Chiefs will study this rule and submit an accepted draft to the National House of Chiefs. At the National House of Chiefs, the draft will be studied, and, if it meets the approval of all, a request that the rule take effect in the community concerned will be submitted to the Minister of Chiefs. The Minister, after deliberating with the Attorney General, may cause a Legislative Instrument to be passed by Parliament so that the rule of law takes effect. If the draft Legislative Instrument is adopted by the Parliament, the President will have to approve of this draft, and it will be referred to as a common law rule of customary origin.

The National House of Chiefs is authorised to "undertake progressive study, interpretation and codification of customary law with the view to evolving, in appropriate cases, a unified system of rules of customary law, and compiling the customary laws and lines of succession applicable to each Stool" as per the Chieftaincy Act 2008- Act 759(49). However, the traditional institutions (Traditional Councils, Regional House of Chiefs, and the National House of Chiefs) since 1927 have requested but not been given any technical and financial support from the government for the codification of informal rules of customary laws. This request was refused in 1927, and reasons laid out were that the internal organization of the chieftaincy is the business of the traditional states in their different localities and not that of the government. The position of the government on this issue has not changed over time.

The chieftaincy institutions still retain control and management of stool lands, and the government and parliament can only negotiate with them on customary land matters. The customary obligations of chiefs to manage land on behalf of their subjects through the role of informal norms have blurred lines of accountability and transparency. Chiefs have argued that relations between them and their communities are the business of the traditional locality concerned, and so they should be left to settle their chieftaincy and land matters according to their customs and traditions without government interference.

Attempts by government to create agencies that will oblige chiefs to be accountable for the use of stool land proven futile. The call for chieftaincy accountability started in 1985 when the Provincial National Defence Council (PNDC) backed the revolutionary cry of 'probity and accountability' in the constitutional preamble. The accountability decree issued focused on the head of families and not chiefs.

A head of family or a person who is in possession or control of, or has custody of, a family property is accountable for that property to the family to which the property belongs. A head of family or a person who is in possession or control of, or has custody of, a family property shall 
take and file an inventory of the family property. Where a head of family fails or refuses to render account or file an inventory of the family property, a member of the family to which that property belongs who has or claims to have a beneficial interest in the property, may apply by motion to a court for an order compelling the head of family to render account or file an inventory of the family property to the family (Head of Family Accountability Law, 985 (PNDCL 114), Section 1-2).

The PNDC military ruling elite recognised that the informal customary rule failed to enable families to hold chiefs accountable to their subjects. It's difficult to explain why the head of families are held accountable and not chiefs, except that the chiefs hold a quasi-autonomous legitimacy and authority in the Ghanaian State. Maybe this decree was also passed as a first step in redressing family heads. Prior judicial customary law cases analysed in Ollenu (1962) states that individual members of a household have no locus standi to sue the head of the house- Adude vs. Onano (1946) 12 W.A.C.A. 102, 104, even though the 1992 constitution, Article 36 (8) states that:

The state shall recognise that ownership and possession of land carry a social obligation to serve the larger community and, in particular, the state shall recognise that the managers of public, stool, skin and family lands are fiduciaries charged with the obligation to discharge their functions for the benefit respectively of the people of Ghana, of the stool, skin, or family concerned and are accountable as fiduciaries in that regard.

This article makes clear that chiefs should be accountable, but it does not state by which mechanisms they can be held accountable to their subjects in land administration matters. During an interview with an officer at the Lands Commission, he said that subjects found it difficult to hold their chiefs accountable because tradition did not permit a subject to question the chief. He stated further that even sub-chiefs who wanted to hold their senior chiefs accountable did this indirectly by implicating the land commission in the matter, never by confronting the chief directly. In 1991 the Supreme Court presided over a case between a chief and his subjects in Kumawu, on compensation money paid for stool land (Owusu and others vs. Agyei and others -2 GLR 493-517). The Supreme Court emphasised that:

The fear of embarrassment to a chief should not be the ground for a chief not to account when a genuine demand for an account is made 
by his subjects... It was Mensah Sarbah who enunciated the principle of immunity of the head of family from accountability which was later extended to cover occupants of stools. Now that by the Head of Family (Accountability) Law, 1985 (PNDCL 114), a head of family is made accountable to his family, I would recommend a similar law to be made by the legislature to cover occupants of stools.

While a subject can bring his chief before the court of law to account for stool land revenue, enforcement will be challenging because the expenditures of chiefs are not approved by any agency (Kludze, 1987). This means that stool land revenue is spent at the discretion of the chief and his elders, and this is explained in (ibid: 155):

Our courts apply legal principles of accounting which are based upon and are derived from the rules and practices of English courts. There is, therefore, inherent in this a difficulty of reconciling the English practice with the established principles of the Ghanaian customary law. The incompatibility lies in the conflict between the unfettered discretion of the head of family in the handling of family property on the one hand, and on the other hand, the right of the applicant to challenge the state of account... The court will have to determine which of the contentious items of expenditure or disbursement of family property should be disallowed... Whether it is desirable to substitute the wisdom of the judge for the discretion of the head of family is an issue which may lend itself to debate.

Apart from the courts, the Office of the Administrator of Stool Land Administration (OASL) is constitutionally mandated to collect and disburse all stool/skin land revenue collected as rents, royalties, dues and other payments. They are also expected to consult with traditional institutions and the Lands Commission in a matter relating to administration and development of stool land by providing them with "all relevant information and data" as per Article 267 (7) of the 1992 Constitution. Section 74 of the 2008 Chieftaincy Act also requests that yearly statements of revenue and expenditure on stool lands from the OASL be made available to chiefs as a form of accountability. Here we see a scenario where the chiefs have the legal authority to demand that OASL should be accountable for stool land revenues, but neither OASL nor any state land agency can hold chiefs accountable in how these revenues are used in their different localities. The OASL is, therefore, accountable to chiefs and not vice versa. 
The Auditor-General is one of the institutions mandated to audit chieftaincy institutions as laid out in the 1944 Native Authority system. When the chieftaincy institution was separated from Local Authorities in 1951, the State Councils continued to function as a state agency of administration. The Audit department audits the revenue of the Traditional Councils within an informal framework, where chiefs are not subject to any approval on the use of this budget. According to Appiah (2012), in the 2009 report, 28.8\% of chieftaincy organisations had kept their accounts up to date. The reasons given for this lapse were usually the lack of technical resources and qualified personnel (Quartey, 2003; Sakyi, 2003). Chieftaincy institutions are quasi-state institutions but are expected to self-finance their activities like travelling for meetings and payment of personnel like lawyers with little or no finance, so these reports are always in arrears (Kludze, 2000). Most governments, since independence, have assumed policies of non-intervention in chieftaincy matters.

In this section, it is made clear that chieftaincy institutions have the choice to cooperate with or resist government policies on customary land administration. The power and authority to either cooperate or resist government policy have roots in colonial policies which have been adopted by the contemporary government. The power and authority conferred by the state on chieftaincy institutions have led to overlaps and conflicts with land agencies who aim at controlling customary lands. Later chapters will look at how farmers create networks with other actors or seek forums through which they can gain access to land or maintain access routes to land and other resources. It is not uncommon for lands to be leased or rented out to multiple persons, and with the value of land going up, on-going land litigation cases are increasing. The use of unapproved development schemes are all problems inherent in the weak land administration system which exist in Ghana.

The National Land Policy in 1999 and the Land Administration Programme (LAP) are all reforms which have been introduced to improve on land management by making chiefs accountable to their subjects and creating a market for land where everyone can have access to land. This governmental intervention can be seen as a ploy by the government to take over control of land from chiefs to serve their personal interest. In the next section, I will use the Land Administration project as an example to explain how governmental interventions are introduced to subjects and how different subjects with different interests negotiate to have their objectives met while presenting a global front to governed subjects. Here I will discuss the effects on the LAP on customary land administration controlled by chiefs.

\subsubsection{Customary land tenure and Land Administration Project}

In the $20^{\text {th }}$ century, the Peruvian economist Hernando de Soto argued that the problem of insecure land in developing countries in Africa was as a result of the nature of traditional land ownership. He said that landed asset of people in developing countries was defective because 
land could not be traded or used as collateral for a loan; that is, land was dead capital. $\mathrm{He}$ advocated for a private property rights system in which land can be individually owned. De Soto's persuasive modernisation theory came at a time when the Ghanaian government was convinced that the way out of poverty and underdevelopment was through secured private land titles (Soto, 2001). The government started with the drafting of the National Land Policy, whose objective was the "judicious use of the nation's land and all its natural resources by all sections of the Ghanaian society in support of various socio- economic activities undertaken in accordance with sustainable resource management principles and in maintaining viable ecosystems" (Ministry of Lands and Forestry, 1999: 6). In 2003, other land reforms like the Land Administration Programme (LAP) followed suit.

The objectives of the LAP include the institutionalisation of all public land agencies the Survey Department, the Land Valuation Board, the Lands Commission and the Land Title Registry - under one umbrella called the New Lands Commission. A subunit of this organization will be the Customary Land Administration Unit which will help establish land secretariats under the control of the chief, tindana or family head. The project also includes the harmonization of land policies with constant monitoring and evaluation. The Lands Commission is also intended to be market-focused and remove government from the management of stool/skin land (Karikari, 2006). The World Bank (2011) suggested that LAP will be beneficial to Ghana in four ways; firstly, it will reduce conflicts in land ownership and land use, providing secure land titles in both rural and urban areas, facilitating socio-agricultural and industrial development. Secondly, it will reform public sector management structures and aid in land administration decentralisation at the local level structures, with the aim of rationalising and institutionalising land administration. Thirdly, it will facilitate the participation of civil society and the private sector in checking excesses of public sector management and promote transparency and selfhelp initiatives for growth and development. Fourthly, it will assist in street naming which would facilitate identification of businesses, and aid local councils in collecting revenue from them.

Due to the many different aid agencies donating funds for the accomplishment of the various components of the LAP, implementation of an accountable and transparent land administration program has proven difficult, because different institutions of these organisations had diverging agendas. From Table 5.3, it is clear that, while the World Bank is pushing for individual land rights and titles to land through a market-centered approach, the Department for International Development (DFID) is pushing for control of stool administration through strengthening of the customary system in place to make it more efficient (Ministry of Lands and Forestry, 1999). The involvement of varied international organization with different agendas in a project shows clearly the idea of transnational governmentality as purported by Ferguson and Gupta (2002). This occurs where transnational alliances are forged by activists with complex networks of international and transnational funding, as explained in Chapter 2. Here 
we see clearly the interaction of the state and international organisations serve to reorient how the society is governed from a globalised /universal level, and how this plays out at the local level during implementation. Transnational governmentality legitimises the activities of the state at a globalised level and also provides spaces within which international actors can legitimise themselves as local and global development agents of positive change. The LAP is also a forum through which the different international organisations mentioned above, legitimise their ideologies and worldviews on property rights and resource access in Africa and the world.

Table 5.4: The Politics of LAP Aid

\begin{tabular}{|c|c|c|c|c|}
\hline Donors & $\begin{array}{l}\text { Budget } \\
\text { US \$m }\end{array}$ & $\begin{array}{l}\text { Percent } \\
\text { (\%) used } \\
\text { as at } \\
31 / 12 / 2010\end{array}$ & Reform component supported & $\begin{array}{l}\text { Date of } \\
\text { Funding } \\
\text { (with ex- } \\
\text { tension) }\end{array}$ \\
\hline $\begin{array}{l}\text { World } \text { Bank } \\
\text { (IDA) }\end{array}$ & $\begin{array}{l}20.51 \\
\text { Loan }\end{array}$ & $99 \%$ & $\begin{array}{l}\text { 1. Land policy and regulatory } \\
\text { framework revised and harmo- } \\
\text { nised with practiced customary } \\
\text { land laws (includes legally conclu- } \\
\text { sive confirmation of the continued } \\
\text { validity of customary freehold and } \\
\text { other customary titles.) } \\
\text { 2. Institutional reform and develop- } \\
\text { ment: } \\
2.1 \text { Restructuring public sector } \\
\text { land agencies into a single agency } \\
2.2 \text { Decentralisation of restruc- } \\
\text { tured single agency to the regions } \\
\text { 3. Improving land titling registra- } \\
\text { tion, valuation and information sys- } \\
\text { tems } \\
4 \text {. Project coordination, monitor- } \\
\text { ing, and evaluation }\end{array}$ & $\begin{array}{l}18 / 08 / 2003 \\
- \\
30 / 06 / 2011\end{array}$ \\
\hline $\begin{array}{l}\text { Department } \\
\text { for Interna- } \\
\text { tional }\end{array}$ & 9.02 grant & $81 \%$ & $\begin{array}{l}\text { 2.3 Strengthening customary land } \\
\text { administration through the devel- } \\
\text { opment of publicly }\end{array}$ & $\begin{array}{l}\text { 08/06/2004 } \\
- \\
31 / 08 / 2009\end{array}$ \\
\hline
\end{tabular}




\begin{tabular}{|c|c|c|c|c|}
\hline $\begin{array}{l}\text { Development } \\
\text { (DFID) }\end{array}$ & & & $\begin{array}{l}\text { accountable Customary Land Sec- } \\
\text { retariats (CLSs) }\end{array}$ & \\
\hline $\begin{array}{l}\text { Canadian In- } \\
\text { ternational } \\
\text { Development } \\
\text { Agency } \\
\text { (CIDA) }\end{array}$ & 1.03 grant & $62 \%$ & $\begin{array}{l}\text { 1.4 Policy studies on gender and } \\
\text { analysis } \\
3.4 \text { Improving deed and title regis- } \\
\text { tration } \\
\text { 3.7 Piloting demarcation and reg- } \\
\text { istration of allodial boundaries }\end{array}$ & $30 / 06 / 2011$ \\
\hline $\begin{array}{l}\text { Kreditanstalt } \\
\text { fur Wied- } \\
\text { eraufbau } \\
(\mathrm{KfW})\end{array}$ & 6.03 loan & $43 \%$ & $\begin{array}{l}\text { 2.1 Construction of new head of- } \\
\text { fice for the unified new land } \\
\text { agency } \\
\text { 3.2 Cadastral mapping } \\
\text { 3.7 Piloting demarcation and reg- } \\
\text { istration of allodial boundaries } \\
\text { 3.8 Piloting systematic land titling } \\
\text { and registration }\end{array}$ & $\begin{array}{l}26 / 11 / 2004 \\
- \\
30 / 09 / 2011\end{array}$ \\
\hline $\begin{array}{l}\text { German } \\
\text { Technical } \\
\text { Assistance } \\
\text { Corporation } \\
\text { (GTZ) }\end{array}$ & 3.98 grant & $19 \%$ & $\begin{array}{l}\text { 1.1 Revision of policies, laws and } \\
\text { regulations for effective and effi- } \\
\text { cient land } \\
\text { administration (specifically the as- } \\
\text { certainment and codification of the } \\
\text { rules of } \\
\text { customary law in local communi- } \\
\text { ties) }\end{array}$ & $\begin{array}{l}11 / 10 / 2001 \\
- \\
31 / 03 / 2008\end{array}$ \\
\hline $\begin{array}{l}\text { Nordic Devel- } \\
\text { opment Fund } \\
\text { (NDF) }\end{array}$ & 6.92 loan & $92 \%$ & $\begin{array}{l}\text { 3.5 Land use planning and Ortho- } \\
\text { photo Mapping }\end{array}$ & $\begin{array}{l}\text { 20/12/2004 } \\
- \\
30 / 09 / 2011\end{array}$ \\
\hline $\begin{array}{l}\text { Government } \\
\text { of Ghana }\end{array}$ & 9.56 & $36 \%$ & $\begin{array}{l}\text { All components as required for } \\
\text { counterpart funding }\end{array}$ & $31 / 12 / 2011$ \\
\hline Total & 55.05 & & & \\
\hline
\end{tabular}

Source: compiled from DFID (2010), World Bank (2003c, 2008), MLF (2006), MASDAR (2011b)

Appiah (2012: 264) conducted interviews with Mr. Jimmy Aidoo on the accountability of chiefs in stool land administration, whereby Appiah was made to understand that: 
(y)ou don't ask 'Are the Chiefs accountable?', even if you are trying to use those words, the word you should use is 'cooperation'. You have to ask, 'Do the traditional authorities cooperate with the CLS?'... So the word is cooperation, not accountability... The word accountable, you are looking at democratic process. Some people are even saying they are not transparent. You don't choose or use those words when you go to the Chiefs. I took the World Bank to the Asantehene and I coached them the words to use... So if you say accountable and all that, you are threading in a very dangerous territory, they won't mind you, they will say pack your things and go.

Dr. Odame Larbi, LAP Project Director, shares the opinion of Mr. Jimmy Aidoo when he was interviewed by Appiah. He explains thus:

It is the way the traditional system is organized. You know when you go to the chiefs in their palace, in our culture when the chief sits in public and he is adjudicating any case or performing any function, he is the last person to speak, and once he speaks no one else speaks again. When the chief speaks nobody challenges him, in public; when the chief speaks nobody can tell him that he is lying, in public... Their own subjects cannot call them to account because of the way the traditional institutions are organized. If you go and demand in public that the Chief should account, I am sure that before you leave that durbar grounds to your house, if you are in a village they would have burnt your house or whatever they do they would intimidate you to leave so those structures do not allow the people to demand accountability (ibid: 264)

During an interview with an anonymous officer at the Lands commission, I asked if the creation of the Customary Land Secretariat (CLS) has in any way made the chiefs more accountable. I was informed that, unfortunately, the CLS are not experts and lack the capacity to carry out their duties effectively. However, there has been a reduction of land litigation and double allocation, and an increase in the management of record keeping of land transactions. He went further to give a vivid impression of chief's allocation practice, stating:

I have always been saying that, hmmm in Ghana we are underdeveloped because of our land tenure system. It is part of the problem. Here 
is the case where there is a sitting chief. Hmmm you know, land is money and government can task land and raise a lot of money for development. An area becomes ripe for development then a chief goes in and zones the place. If we have about fifty plots, just fifty plots and you are selling each plot ten thousand Ghana Cedi multiple it and see how much money the chief can raise from these sales. You see, but he sells the land and then spends the money on himself and the immediate people around him, without being held accountable for how he spends the money. There is no law compelling him to account, except that one person in the family or in the palace may be he is enlightened he would maybe ask a question, oh where is the money? The chief himself would take so much money and then spend it with the people around him. If you go to the palace, there is somebody a child there sometimes who is unable to pay his school fees. I hope you understand. If you go to Accra, It is worse what they do. He sells the land; the next thing to do is to marry another wife. I am not saying all the chiefs are bad, some of them are good. The sad thing is that you know the money that is accrued from the sales; he does not use it for the development of the area. He would sell the land without any development and then expect the government to come in to provide the infrastructure services; road, water, electricity. Do you think this is fair? Is not fair I can tell you that when you go to Accra, chiefs are getting a lot of money they are selling lands, for millions of dollars but where do these monies go..., they are not being held accountable.

Additionally, he mentioned the difficulty of junior members of the traditional institution to hold their senior colleagues accountable or the other way round. For example, during a stakeholder meeting to present our preliminary results, the paramount chief of Tamale complained that the traditional system in Dagbon has made it difficult for senior chiefs to hold junior chiefs accountable when administering land on behalf of the people. He said senior chiefs could only advise junior chiefs on land use and management, but cannot decide on how they should control their lands. An example of conflict between chiefs on accountability of land 'sales' or leases can be deduced from my respondent's statement below:

Yeah, a sub-chief is challenging his substantive (senior) chief in court.

$\mathrm{He}$ is enlightened. The unfortunate thing is that he has roped the lands 
commission into the case, but if you listen to them, the lands commission is not the target but the senior chief is. The substantive (senior) chief has raised so much money from allocating lands and the subchief wants to know, where the money is. If you listen to them, that is what they are saying. The case is in court, but because the junior chief cannot sue the senior chief, he has just sued the lands commission. He believed that in suing the lands commission, the substantive chief would be roped indirectly. This way he will not be accused of suing a senior chief. Some sub-chiefs are using this strategy to get their senior chiefs to be accountable since there are no law compelling chiefs to be accountable.

From the above direct quotes from interviewees in the field, it is clear that customary land administration is in the hands of the traditional institutions. Government land agencies were created to work alongside traditional institutions for a better land administration system, but not much has been achieved in making this system transparent. The relationships between chiefs and government land agencies have been fluid; there are sometimes cordial and other times conflictual in land administrative matters. This is because the chieftaincy institution has impunity in the courts, due their role as custodians of land or trustees for the community. They also have statutory and judicial powers to manage and administer land with little or no interference constitutionally from the parliament and Government. Due to the flexibility of 'practised' and 'legal' versions of customary laws chieftaincy institutions can always reinvent or recodify customary laws to suit their agendas at any given time and space (Kludze, 1987).

\subsection{Customary ownership under siege}

Land relations in Northern Ghana are increasingly contested especially with rapid urban growth, which has led to an increase in the value of land and lucrative land markets in the city, as previously explained in Chapters 1 and 4 . Lands which were used for agricultural purposes are now being leased out to estate developers for residential and commercial activities. These changes in land use patterns in the city have led to collective conflicts between chiefs and urban vegetable farmers who are increasingly losing their lands. This mutation in the customary land tenure system is creating new categories of losers and winners, and reshaping inequalities in communal land distribution within the affected communities.

As discussed in section 5.3, Chiefs are now, more than ever, allocating land for their personal gain and not for the development of the people. This practice over time has resulted in wealth accumulation and socio-cultural power of chiefs (Berry, 2013). Even though traditional authorities have been praised by the World Bank for effectively allocating land and, in 
some cases, not inhibiting agricultural productivity (Manji, 2003). The World Bank still champions individual land rights and titles through a market-driven economy, which has partially resulted in the introduction of the Land Administration Programme in Ghana. In the Northern Region of Ghana, land alienation was not possible in the past, as mainly farming use rights were granted on customary lands. Chiefs granted rights to individuals to use land on the basis of verbal agreement, after which the land was given back to the community along with all developments on it if the individual wanted to leave the community permanently. This practice was solidified through the Dagbon tradition as explained in Chapter 3 under section 3.4.2. With urbanisation and population pressure there are increasing demands for more permanent land titles. The right to sell/allocate land is now taken for granted by chiefs.

\subsection{Conclusion}

In this chapter, I have discussed how lands controlled by the tindanas are taken over by the chiefs through political conquest and the tindanas relegated to the background. I have also explained how chiefs legalised their control over land by reinventing or reconstructing traditional norms with the collaboration and support of the colonialist and local businessmen. The reinvention of tradition did not only benefit the chiefs but also suited the colonial government's interest in getting access to land indirectly through the chiefs. Later, through the use of intermediaries such as Acts, laws and ordinances the colonist negotiated secure access and control over certain resources like lands and minerals.

Furthermore, with the creation of land agencies like the Survey Department and land commissions through different acts, overlaps over land administration between chieftaincy institution and state land agencies were made evident. These overlaps and ambiguities became more pronounced after independence, as no legal document or legislature stated the limitations of a chief or state land institution in administering land. This led to an uneasy relationship between the state and the chiefs, resulting sometimes in conflicts, but also in moments of cooperation, as depicted in Figure 5.2 below with condensed examples. 


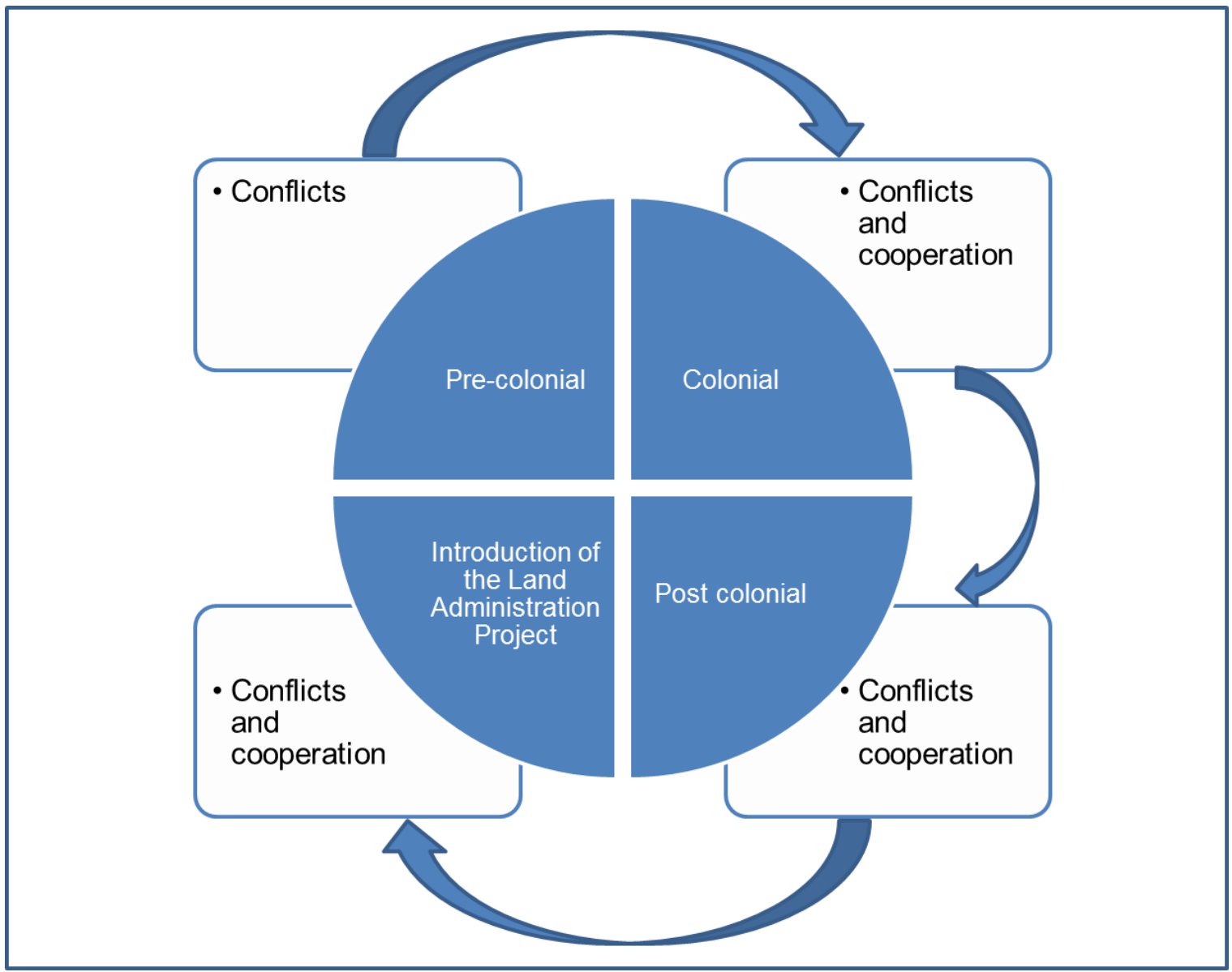

Figure 5.2: Historical relations between chiefs and different state authorities Source: Author's fieldwork, 2015

Pre-colonial - Chiefs conquered the tindanas through wars and took control over land.

Colonial - Colonists collaborated with the chiefs to have access to land but also formed land agencies which gave them more control over land they had acquired. In addition, conflicts over resource access resulted when the land bills and acts were proposed with the intention of taking control over lands in the Southern parts of Ghana. In the Northern territories, all lands were vested in the crown with little or no conflicts with the chiefs, who did not understand the implications of this "new ownership."

Post-colonial - After independence, the new government vested all lands in the Northern and Southern parts of Ghana in the government to punish the chiefs who were accused of supporting the colonial government. Over time, the chiefs' control over land has changed depending on the political government at a given period of time. Presently, the 1992 Constitution empowers chiefs' control over land, but some land agencies have been created to work alongside chiefs in order to establish a transparent land tenure system. This fight for accountability and transparency has led to more ambiguity and overlaps in land administration, resulting in both conflicts and cases of cooperation between these two institutions. 
This uneasy relationship between chiefs and the state has resulted in shifts of power over time and space, reconstructing and redefining the land tenure system in Ghana. These shifts in power and authority over land have various implications for resource access and use, as explained above. The lack of planning laws, as explained in Chapter 4 and the uneasy relationship between chiefs and the state over the years has created spaces or gaps within which farmers can gain access to and control over resources for urban agricultural practices, such as vegetable production. In Chapters 6 and 7 I will detail how farmers gain and maintain access to different resources for vegetable farming, not only because they have a right to these resources but also because they have created social relations and acquired knowledge and technology which gives them the ability to access these resources. 


\title{
Chapter 6 - Resource Access
}

\begin{abstract}
"People and institutions are positioned differently in relation to resources at various historical moments and geographical scales. The strands thus shift and change over time, changing the nature of power and forms of access to resources" (Ribot and Peluso, 2003: 158).
\end{abstract}

"Boundaries are generally defined not with reference to surveyed maps, but to physical landmarks such as hills, streams, trees and anthills. These landmarks shift with time. There is therefore constant land litigation over ownership and boundaries" (Kasanga, 2003: 7).

\section{Introduction}

In Chapter 4, I showed that the agricultural system in the Northern Ghana has been changing, albeit slowly, due to different governmental interventions. I explained how the agricultural practices of the people are being shaped by the interests of different actors who are somehow embedded in multiple governmental interventions. In Chapter 5 I explained how uneasy relations between chiefs and government over land control have opened up spaces in which farmers are negotiating for access to and control over land and other resources. Chapter 6 will discuss how farmers gain access to the resources they use in dry season vegetable farming, and Chapter 7 considers how farmers maintain and control thes resources. These chapters are separated in order to streamline the structure of the thesis, but the information provided cuts across the chapters and overlaps in some instances. As explained in Chapters 1 and 5, land takes center stage in this study because rapid urbanisation in the study setting has brought this issue to the fore, as farming competes with other land uses for residential and commercial purposes.

For any agricultural practice to take place one needs access to a variety of relevant resources. The resources implicated in vegetable production are many. They include land, water, seed, manure/fertilizer, technology, tools and knowledge. In this chapter, I will explain how land, water, and seeds are accessed for vegetable production in the city of Tamale and its environs. I will examine the different socio-political and institutional processes which farmers must negotiate and manipulate in their social setting in order to access land, water, and seed in vegetable cultivation. To avoid repetition in this chapter and the next, I will explain how 
resources are accessed by summarising information gathered from farmers in all my case studies in Chapter 6, while in chapter 7 I will present an extended case study.

Access to resources by farmers is shaped by many factors, including the urban setting where they find themselves, the cultural knowledge they have, the socio-political and economic capital they can access, institutional affiliations and the historical past linked to the socio-political situation at the time of access. Processes of access could act through mutual learning, membership of associations, involvement in cooperative or conflicting events or institutional cooperation and conflict, as well as socio-economic arrangements. Technology also shapes the process of access in that it can enable or constrain access to resources for vegetable gardening through adoption, adaptation or creative innovation. The search for land is linked to water, as this agricultural practice often takes place in the dry season, when irrigation is crucial.

In the first section of this chapter, I will illustrate the different socio-political processes through which land can be accessed in Tamale as they are being enacted in the present $21^{\text {st }}$ century based on primary data. In the second and third sections I will present different cases relating to how water and seeds are being accessed by farmers for vegetable production in urban and peri-urban Tamale. Concepts and theories discussed in Chapter 2, such as forum and institutional shopping, resource access theory, political ecology, governmentality and enrolment will be used in analysing data on how farmers gain access to resources.

\subsection{Land ownership in practice}

Even though laws exist to streamline land ownership and rights, as explained in Chapter 1, in practice people have overlapping rights over land (Hughes et al., 2011). In this section, I will explain how these rights are operationalised. Land rights could range from temporary to permanent usufruct rights, common property rights and individual land rights. For example, in Tamale, farmers have usufruct rights to any piece of communal land for farming. In understanding how farmers gain access to land for vegetable cultivation, it is necessary to reiterate here that access is broader than property, as discussed in Chapter 2. It constitutes bundles of power that one can access even when one does not necessarily have a right to otherwise (Ribot and Peluso, 2003). In this study area, I have identified four land rights attached to land in Tamale and have diagrammatically shown who has these rights over land and what laws or norms legitimise them. These rights to or interests in land may be allodial, usufructuary, private/individual and administrative, as illustrated in Figure 6.1. 


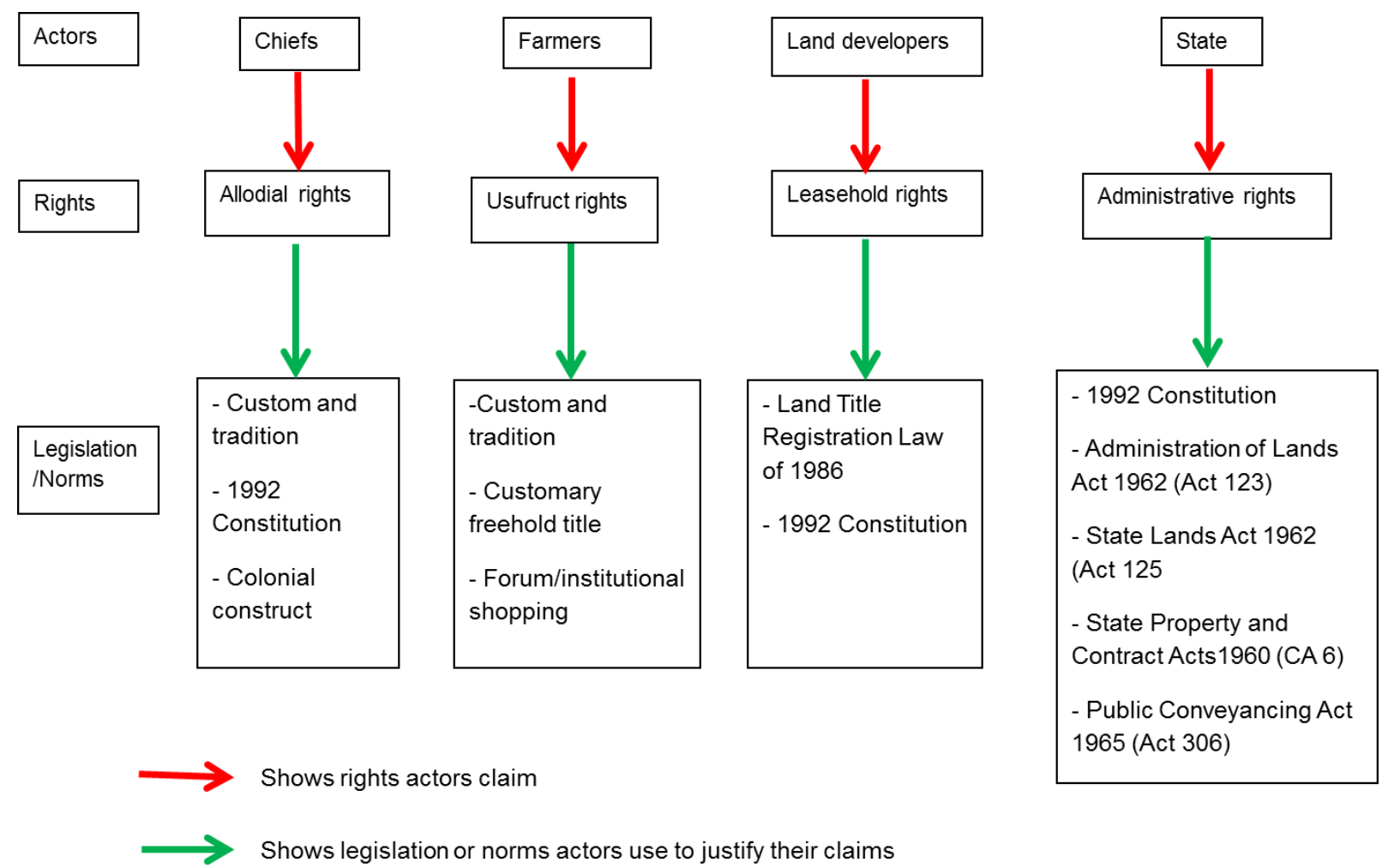

Figure 6.1: Socio-political processes of land access in Tamale Source: Fieldwork, 2015

Chiefs have allodial rights over land. They are the custodians of land for the people. This allodial right gives them a trusteeship position in the community, where they are expected to allocate these lands for various uses which benefit the whole community. These lands can be assigned but not sold due to the spiritual nature accorded to land in the community. Chiefs get their legitimacy - that is, power and authority over land - from the social norms and traditions of the people which have existed since the $14^{\text {th }}$ century after they took over control of land from the tindanas (earth priests). This legitimacy has deep roots in the socio-political construct of the community, and it is widely accepted since it is grounded in personal relationships and the social structure of the community. This type of legitimacy is negotiated to fit with the changing socio-political situations. This legitimacy has been solidified over time through colonial construct, referred to by authors like Berry (1993), Amanor (2001) and Nchanji and Bellwood-Howard (2016a) and discussed in Chapters 4 and 5.

This invention of tradition also accorded male dominated institutions like the chieftaincy leverage over land ownership and control. In addition, the 1979 and 1992 Constitutions have permitted chiefs to gain more control and management over land, even though they are expected to collaborate with government land agencies. Only chiefs have allodial rights over land, and this right is considered supreme in the country and cannot be contested. Allodial 
rights are the main thread through which all other rights are derived, and since they are under customary law, their implementation is fluid and negotiable, as explained in Chapter 1.

Farmers obtain usufruct rights to a plot of land after presenting a symbolic token, which traditionally took the form of a kola nut, to the chief as explained in chapter 1 and Figure 6.2 below. This type of right to land can be inherited and transferred. According to traditional laws, land can be taken from a usufruct owner by an allodial right holder and allocated for development purposes to benefit the community with the consent of the one who had usufruct rights on the land. Presently, due to the current lucrative land market and urbanisation, farm lands are being allocated to land developers without the consent of the usufruct owners. An important distinction needing clarification is between an allocation and a lease. Chiefs allocate lands; this contract has no time span, so the chief can take back the land at any time. A lease on land can only be obtained at the Lands Commission, and in the lease, a specified period of time is stated during which it can be used by the lessee. The traditional norms attached to land are fading away as chiefs now consider themselves as 'landlords' and not custodians of land for the people (Yaro, 2010).

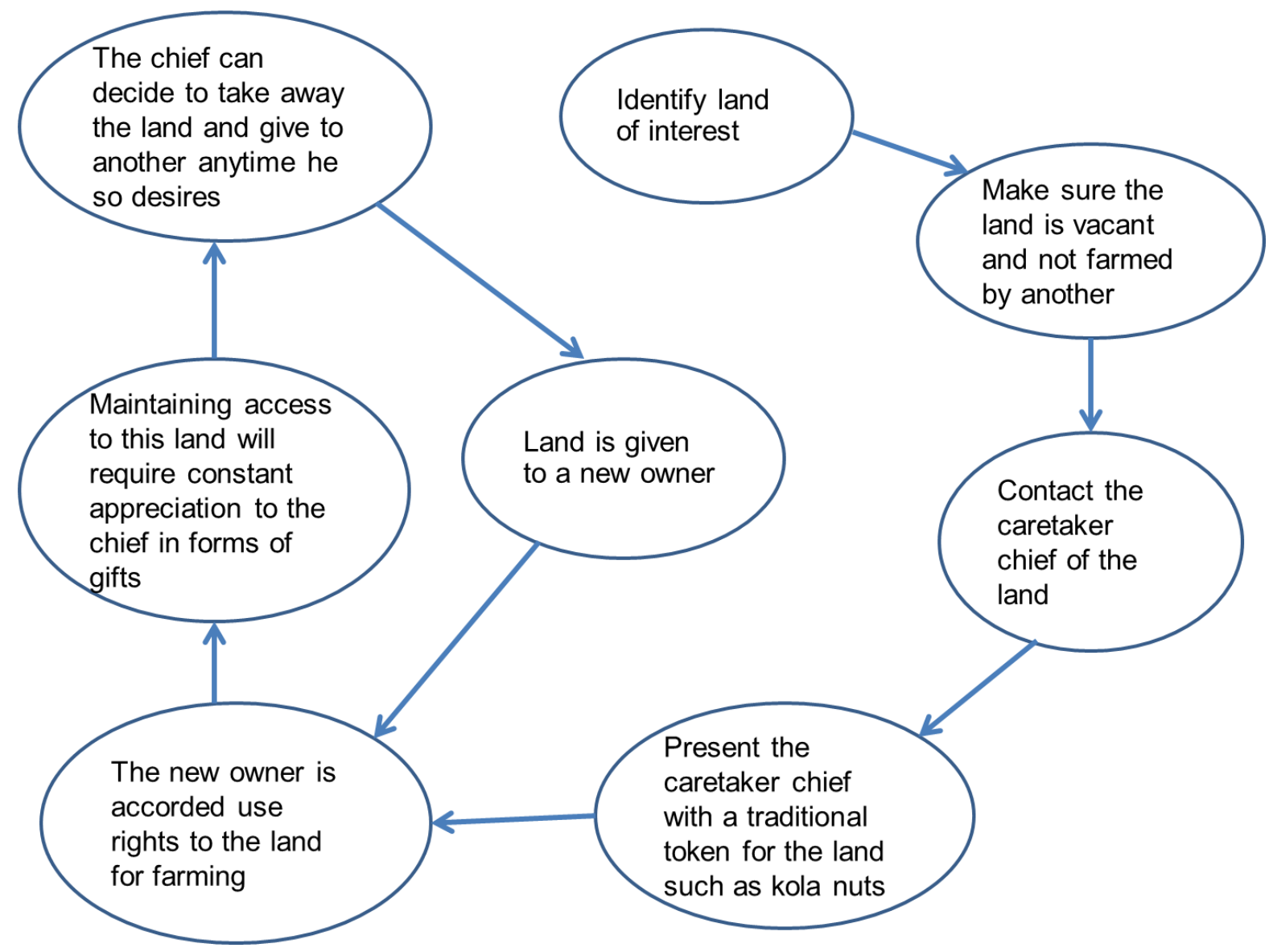

Figure 6.2: Access to communal farmland by local indigenes

Source: Author's fieldwork, 2014 
Most farmers gain their rights to land through social norms and tradition, which is continually reconstructed through different historical recollections of how their great grandparents occupied these vacant lands which they now use for farming. Few farmers have freehold interest in lands, so many rely on usufruct right over communal land for farming. As a result of increased allocations of lands by chiefs for other purposes apart from farming, many farmers who had use rights to these lands are being evicted, and so are seeking other routes of access to lands outside the city. Farmers are soliciting the services of non-governmental organizations and research institutes to gain access to land and maintain control over it. The process of choosing one institution or the other through which an actor's interest can be realised is referred to as institutional shopping, a concept which has been explained in Chapter 2. Apart from farmers, land developers also seek access to lands for residential and industrial purposes, through particular institutions that support their agenda or can benefit from their interests.

Land developers can obtain leasehold rights to land, even though this process is long, complex, fraught, risky and expensive, as many interviews with land owners revealed. This process has been diagrammatically illustrated in Figure 6.3 below.

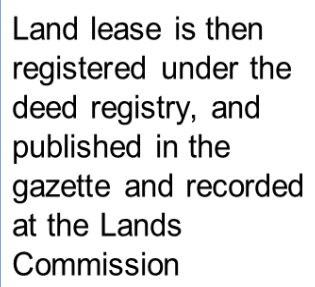

Submit the signed lease to the Lands Commission to be concurred by the regional chairman of the Lands Commission

A lease is
issued to be
signed by the
divisional chief
and paramount
chief (overlord),
witnesses and
the new land
owner

A lease is issued to be signed by the witnesses and owner

\begin{tabular}{|l|}
\hline Individual \\
identifies \\
a plot of \\
land \\
\hline
\end{tabular}

Check with Lands Commission, Town and

Country Planning Department or Customary Land Secretariat if the plot of land interested in is zoned for the purpose needed and if the chief is permitted to allocate this land
Contact chief in charge of the plot of land for an allocation note

Provide the
necessary
traditional token
demanded by the
chief

\begin{tabular}{|l|l|}
\hline $\begin{array}{l}\text { Pay a } \\
\text { processing } \\
\text { fee to get } \\
\text { a lease }\end{array}$ & $\begin{array}{l}\text { Submit the } \\
\text { allocation note } \\
\text { and cadastral plan } \\
\text { to the Lands } \\
\text { Commission }\end{array}$ \\
\hline
\end{tabular}

Present the allocation letter at the Survey and Mapping Division at the Lands Commission and later be issued a cadastral plan

Figure 6.3: Process of getting a lease on customary land

Source: Fieldwork, 2015 
According to an interview with an officer at the Lands Commission; acquiring land for residential or commercial farming purpose starts with identifying the land one is interested in. When a plot of land is identified by anyone interested in it, he can contact the Lands Commission to check if the chief in question has the credibility to allocate that land and whether the land has been zoned for the purpose the developer want to use the land for. This information can also be gotten from the Survey and Mapping Division of the Lands Commission, the Town and Country Planning Department and the Customary Land Secretariat. If these criteria are met, then one can approach the chief of the said land for an allocation note, which later needs to be confirmed by the divisional chief if one is dealing with a junior chief.

A traditional token consisting of kola nuts and a cash price, which is decided according to the land area, will be presented to the chief, who issues the allocation note. The kola nut and cash are considered a token collected for sacrifices to be carried out on the land before it is given out and not payment for the land. This is a tradition as land is considered not sold but allocated. During fieldwork, the transactions between a land buyer and chiefs were often referred to as 'land sales' by land 'buyers.' When an allocation letter is given by the chief in charge of allocating the land, the new land owner takes this allocation note to the Survey and Mapping Division at the Lands Commission. The Survey and Mapping Division goes back to the site to check if the site plan reflects the reality on the ground, as private surveyors used by chiefs are not always competent and may place boundary markers at the wrong locations. The team from the Survey and Mapping Division, if satisfied with the site plan, prepares a cadastral plan from the layout.

According to law LI144, any piece of land has to be approved by the regional surveyor for registration purposes. The regional surveyor, who is the head of the Division of Survey and Mapping, would approve the site plan. The new land owner is expected to attach the site plan to the allocation letter and table it to the Lands Commission for a lease. If land requested is for a residential purpose a 99 years' lease is given, if it is commercial or industrial a minimum of 50 years' lease is given. If the land is for farming of permanent crops like cocoa and shea nut, 50 years is given, if the land is for farming of seasonal crop like maize or rice, a 25 years' lease is granted. This applies only to Ghanaians, as foreigners are given not more than 50 years lease for residential or commercial agricultural activities. When these documents, such as the site plan, allocation note and cadastral plan, are presented at the Lands Commission, a lease form is produced. This lease form gives a column for the signature of the divisional chief and the overlord (paramount chief) of the region, the new land owner, and two witnesses. This document is then submitted back to the Regional Chairman of the Lands Commission after all signatures have been appended, and he is expected to give his approval of these documents. 
Before the lease is finalised, records are checked to make sure that the allocation is not in conflict with earlier allocation notes by the chief or another chief, if it is encumbered the lease is sent back to the chief who issued the allocation note. If there is no conflict, then a last trip to the site is conducted to make sure no conflict cropped up on the ground during the processing period. If all is in order, a processing fee is demanded before the lease is registered, showing that the process for a lease is completed. Many landowners in the course of registering their lands stop due to ignorance or lack of finance, as explained by staffs at the Lands Commission.

In Ghana two systems of registration exist: the title registration and the deeds registration. The title registration is exercised in Accra, Greater Accra and part of the Ashanti region, but all the other regions operate under the deeds registry. The difference between the title and deed is vague and it's a product of the LAP which has been discussed in Chapters 1 and 5 . The process of obtaining a title registration certificate is shown in Figure 5.1 in Chapter 5. This certificate is indivisible, and nobody can challenge it unless there is proof that there was some sort of fraud. With the Deeds Registry, the deed can be challenged because the land lease from the deeds registry simply entails the registrar putting a stamp on the document, while the land title certificate procedure is more rigorous. When a landowner has been issued a lease, he is advised by the Lands Commission officers to pay his land tax, which is a stamp duty to be paid at the Internal Revenue Authority.

Government access to land is through a different legal apparatus ${ }^{21}$ which gives the state the constitutional right of eminent domain to compulsorily acquire land for public purposes to benefit the people and the nation, as explained in Chapters 1 and 5. Most lands acquired in this fashion are meant for service provision, such as government schools, public toilets, public markets and health and social government offices, etc. The government has administrative rights over these lands, and the Lands Commission controls these lands on behalf of the state.

The Lands Commission and the Survey Department were created to assist the colonial government in administering customary land, as explained in Chapter 5. In addition, the Town and Country Planning Department, Office of Stool Land Administration and District Assemblies have been charged to collaborate with the chiefs in administering and controlling skin lands for a more accountable and transparent process of land acquisition, post-independence. According to the 1992 Constitution, Article 258 (1b), the Lands Commission is supposed to:

\footnotetext{
${ }^{21}$ Article 20 of the 1992 Constitution, Administration of Lands Act 1962 (Act 123), the State Lands Act 1962 (Act 125), the State Property and Contract Acts1960 (CA 6) and the Public Conveyancing Act 1965 (Act 306).
} 
(A)dvise the Government, local authorities and traditional authorities on the policy framework for the development of particular areas of Ghana to ensure that the development of individual pieces of land is co-ordinated with the relevant development plan for the area concerned.

The Town and Country Planning Department, according to CAP 84 of 1945, is mandated to promote orderly and efficient management of all human settlements in Ghana, meaning they provide planning schemes for the communities in collaboration with the chiefs. According to Article 267 (2), the Land Commission and Administrator of Stool Lands "shall coordinate with all relevant public agencies and traditional authorities and stools in preparing a policy framework of the rational and productive development and management of stool lands" and make available all relevant data and information needed for this consultation exercise. The Administrator of Stool Lands, in accordance with article 267 (2a-c), will establish an account for the collection of stool revenue, royalties, rents and dues, of which $10 \%$ will be paid to the office of the Administrator of Stool Lands to cover administrative expenses. The remaining revenue will be disbursed as follows: $25 \%$ for upkeep of the skin, $20 \%$ to the traditional authority and $55 \%$ to the District Assembly where the skin land is situated.

From the above explanations, it is clear that farmers have only usufruct rights to community land, except in cases where the land is owned by a clan or family. This usufruct right accords them use of these community/communal lands indefinitely as long as the allodial landholders are in agreement with their use rights, as explained in chapter 1 . In recent times, increased population pressure and a growing demand for land by commercial investors have led to an increase in its value. This increased value of land has created a lucrative land market, through which the chiefs are making personal gain. Chiefs, in reacting to the land market, are also in part contributing to the high land prices. This situation is a direct reflection of the activities of Southern Ghanaian chiefs during the economic boom before independence, and even now, as explained in Ubink (2007).

According to Ayee et al. (2008) and Adarkwah (2006), the rights of the chiefs with regard to 'selling' or allocating lands are highly fluid, with multiple interpretations. Many questions come up regarding whom the chief should consult in practice when allocating land, and who should benefit from its sales - the chief or the community. These varied questions and the different interpretations of what is considered 'right,' combined with the complex statutory system have given chiefs the opportunity to sell lands at the expense of their indigenes, especially fueled by their rising political influence on land governance (Berry, 2001; Sarpong, 2006). Chiefs have been influenced by the economic interest they can accrue from land transactions, stating that it is within their rights as trustees to do so (Ayee et al., 2008; Fuseini and 
Kemp, 2015). In the next section, I will explain how farmers access resources for their farm practices amidst the conflicting land interests and overlaps in land administration explained above.

\subsection{How farmers gain access to farm lands}

Farmers have opted for alternative routes of access to land for vegetable cultivation in Tamale. Figure 6.4 shows all open space vegetable sites in urban and peri-urban Tamale identified by the researcher. Within this context, five different open space vegetable sites from urban and peri-urban areas will be selected, and I will explain the process through which farmers access lands in these areas for their agricultural practice. Primary data from different case studies I carried out on land use and ownership in urban and peri-urban Tamale will be used.

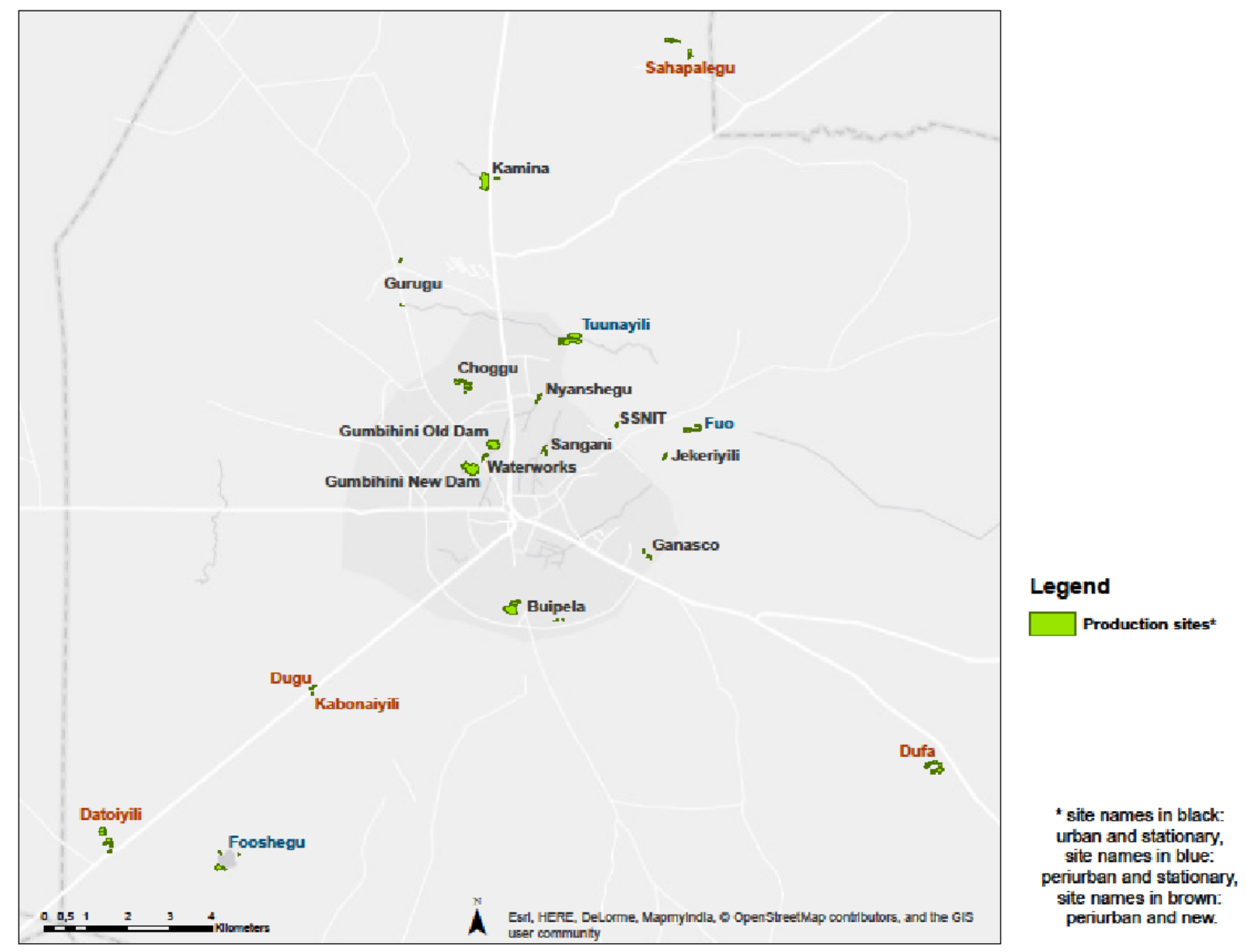

Figure 6.4: Open space dry season vegetable production sites in Tamale

Source: Author's fieldwork, 2015

\subsubsection{Land access through the kin and clans}

Sangani is found in the northwestern region of Tamale. Most of the vegetables grown here are organic, and the water used for irrigation is from a natural spring located on the land. Interviews with a farmer on this site revealed that the land is said to belong to the Nyanshegu clan. The Nyanshegu clan is related to those in other surrounding communities like Choggu, 
Tishegu and Gumbihini, and belonging to this clan is determined through the patrilineal descent. When a man belongs to this clan he can access or own property in any or all of these communities. There are eleven families cultivating vegetables in this site. This land is administered by the chief, who is assisted by elders of the different families, on behalf of the whole clan. Farming here is open only to the members of these land-holding skins, who have use rights to the land. They can share their plots with either relatives or friends, who must also be part of this clan. The Sangani spring is considered a spiritual site for the community, who still today offer sacrifices to their gods there.

This land cannot be sold because it is believed that the chief who sells it will incur the wrath of the gods, which means death. Stories of the passing of a chief and his son as a result of disobeying this local knowledge are constantly repeatedly as a warning to newly-enskinned chiefs of what the gods have in store for anyone who decides to sell or allocate land on this site. An example is the building of a water refinery tank in 2008, which broke down two years later. Most farmers interpreted this even to mean 'the gods are angry with the modernisation of the spring water' since the water is their abode. Dagomba tradition and the Islamic religion have been noted to have different but sometimes similar practices (Imam 2015b). For example, the Dagomba tradition and the Islamic faith both agree on polygyny and the existence of one supreme god. The compatibility between these religions can be seen on this site, which hosts a mosque constructed for Islamic worship by the community, as seen in Figure 6.5, on land where traditional rituals still take place.

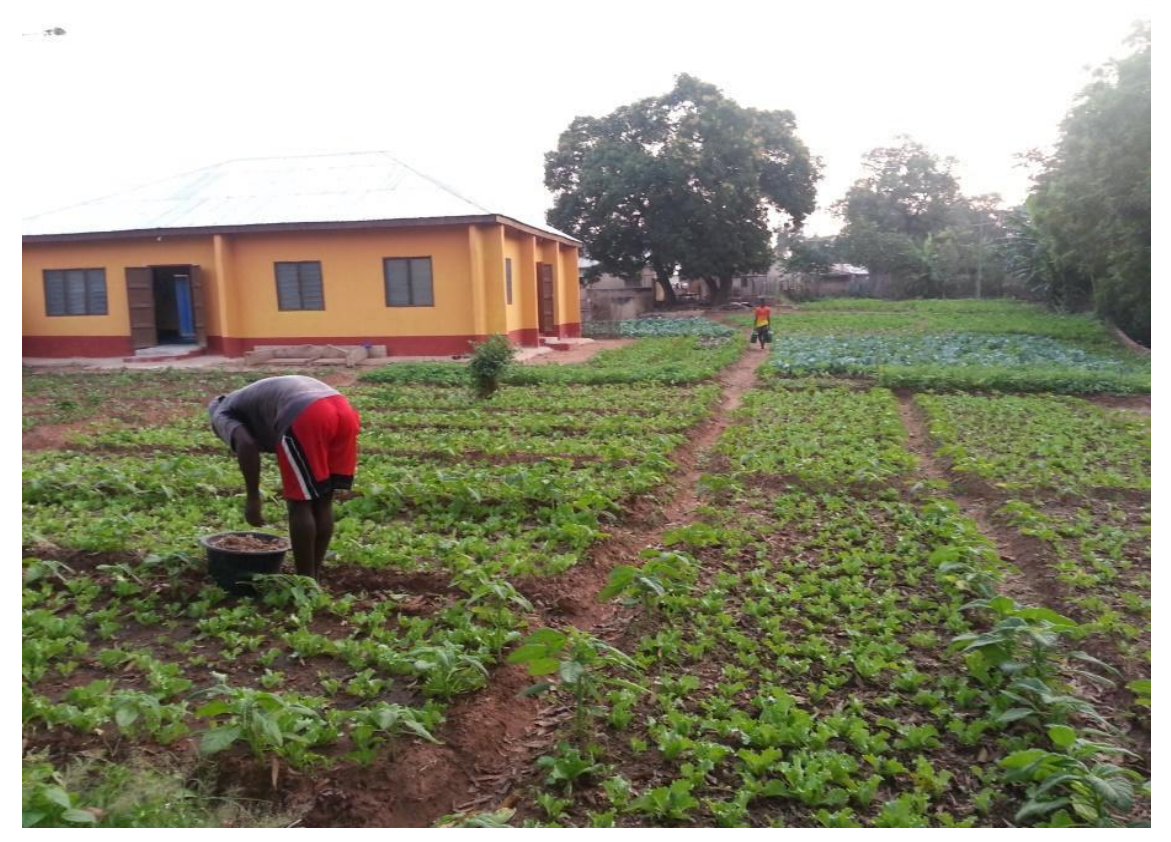

Figure 6.5: Sangani vegetable site with a newly constructed mosque

Source: Author's fieldwork, 2015 
Indigenes farming on this site often refer to historical recollections of how this site came to be a ritual ground in order to fight off development projects proposed by former chiefs for this land. Here we can see how people use events of the past to reconstruct how resources are accessed or managed. The concept of ritual boundaries from Hagberg (2006) shows how historical recollections are used to reconstruct development discourses which favour community development, in connection with Chouin (2002) 'lieux de mémoire' which explains how memory is reconstructed to fit in an actor's agenda. These conceptual ideas are complementary, as they relate to how people use events of the past to take advantage of development discourses to structure how resources should be managed in order to settle conflicts. Here the actors in these sites are using features of the landscape such as the spring water and sacred kapok tree (Ceiba pentandra), to construct a new governance system where the chief cannot outrightly allocate this land without the community's approval. In this way, farmers on this site still retain and maintain access to and control over the land and other resources such as water.

In this section, we have seen how farmers use the ideas of ritual boundaries and memories from the past to maintain their access to land. They use local histories to reconstruct contemporary development project discourses. That is, retelling history becomes a discursive means of accessing and maintaining a resource. Here actors resist the governance system of the chief and create a co-constructed system of governance where chiefs' actions on this site are controlled and sanctioned by elders in the community.

\subsubsection{Land access through private land owners}

Choggu Cheferugeni is situated in the North-Eastern part of Tamale, close to the center of the metropolis. All lands in this area have been sold to land developers for residential purposes. Farm sites found in these undeveloped private plots are usually in and around uncompleted buildings, as shown in Figure 6.6. Most of the farmers have an informal arrangement with individual landowners to protect the land from encroachers and to farm until the landowner decides to build. On these undeveloped plots of land, farmers act as land guards for the private landowners. Most of the farmers, in negotiating for plot of land to farm, have created a cordial relationship with the landowners. These cordial relationships are created through the provision of seasonal crop gifts or salt to land owners in appreciation for continual access to their lands. 


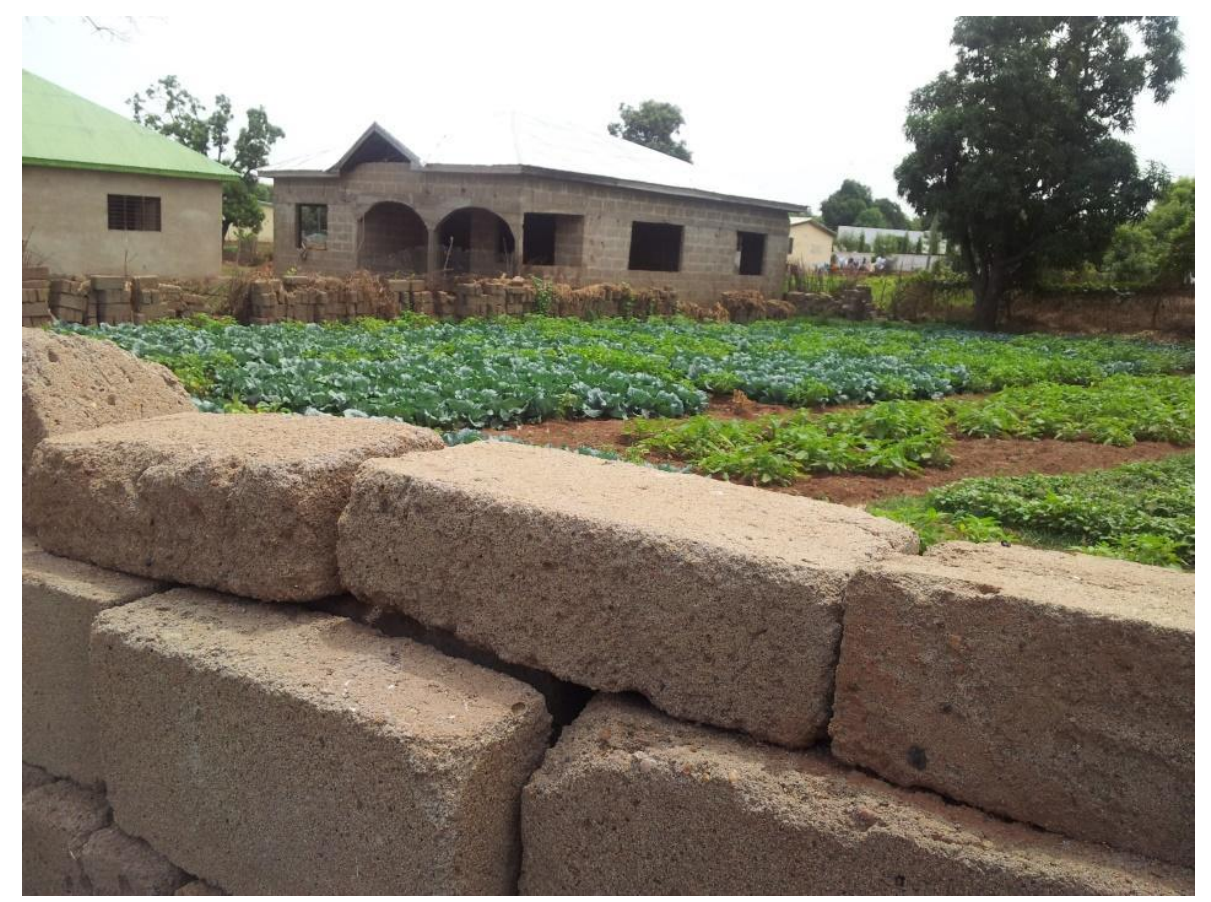

Figure 6.6: Vegetable site in around uncompleted buildings in Choggu

Source: Author's fieldwork, 2014

There is a community dugout in this area that is used by farmers to irrigate their fields. Farmers who are far from the dugout and close to the main road have negotiated with the landowners to get access to piped water installed on the uncompleted buildings of the land owner provided by the Ghana Water Company, which they use to irrigate their farms. That is, the water is contracted by the landowners from the Ghana Water Company for domestic use, but employed by the farmers for commercial vegetable production. When the water company task force comes to this site to check whether the water supplied is used for the purpose it was requested and paid for, farmers in this situation renegotiate further with the task force team. This renegotiation can take the form of unofficial extra cash given monthly or a once per season payoff at the farm site from the farmer to the task force officials.

In other cases, there is no renegotiation, and the team on return to the office immediately reports the change in water use by the farmer to the company water technicians, who will automatically modify the water consumption status from domestic to commercial, which increases the water tariff. Nevertheless, relations between the farmer and the landowner remain cordial if the farmer continues to pay the water bill. The conflicts and negotiations over water consumption, especially during the dry season, are exacerbated by water scarcity in Tamale, as explained in Chapter 1. The loss of revenue by the Ghana Water Company due to a large quantity of water being unaccounted for, as explained by staff from this organisation during a stakeholder meeting in 2015, makes them more likely to follow up on the issues mentioned above. 
In this example, I have shown clearly that access to land relies on maintaining a 'healthy' relationship with the landowner through gifts of seasonal crops and money. This token exchange strengthens relationships between the landowner and farmers, thus ensuring secure access to land for farmers. Here we see that access to land on private property entailed cooperation and negotiations between the individual landowners and the farmers, as well as between the farmers and the task force from the Ghana Water Company. Here the governance system instituted by the private and owners is accepted by the farmers and maintained, so they get continual access to resources.

\subsubsection{Land access through religion}

Sahapalegu is found in the far Northern part of Tamale, towards the Tamale-Savelugu road. This area has a reservoir that was constructed to provide the communities surrounding it with water for domestic use. Lands around this reservoir were used in the rainy season to plant maize and rice, and was left to fallow in the dry season. Fulani herding cattle for indigenes from surrounding communities like Zagyuri and Sughashie live close to this reservoir, far from the community dwellings. They graze cattle under their care around this reservoir during the dry season. During one of my many interviews with Saleman, a farmer in Gumbihini, he told me that he got to hear about the availability of land and water for dry season vegetable farming in Sahapalegu area from an undergraduate student whom his father met at the Sasakawa mosque in Tamale.

This student was enrolled at the Tamale Polytechnique but was sleeping in the mosque because he lacked the money to pay for accommodation. After explaining his problems to Saleman's father, he was given accommodation in Gumbihini to live with Saleman. When this student got to Gunbihini, which is one of the biggest vegetable sites in Tamale, according to Danso et al. (2014) and (Nchanjiet al., 2017), he became curious about the dry season vegetable cultivation and how much profit was involved in this agricultural endeavour.

During one of their several discussions, Saleman informed the student that dry season vegetable cultivation is a profitable activity in the dry season, a time of the year when many people lack employment, as explained in chapter 3 . The student mentioned that there was a reservoir in his village surrounded by land used only in the rainy season for rice and maize cultivation. He stated that no one grew vegetables on these lands during the dry season. Saleman then decided with one of his colleagues to approach the community for land through this student. He first paid a visit to this village with the student, who called together his father and other elders, through whom Saleman introduced the idea of dry season vegetable cultivation and its benefits to the family and community. When the elders were convinced, they then took Saleman and his colleague to the chief of the community for him to explain his project. 
At the chief's palace, Saleman explained his project to the chief after presenting a kola nut to the chief as custom demands. He stated the importance of dry season vegetable practice and his willingness to educate and train farmers interested in this activity. He came along with a water pump which he stated would ease irrigation of vegetables and reduce the labour used on the farm. He insisted that this activity would be communal, with anyone interested participating and sharing in all the work and profits. He also stated that he would contact market women in Tamale to come and buy the vegetables from the farm gate, a practice which takes place in Gumbihini and many other vegetable sites. The chief agreed and in the first year of farming Saleman was allocated less than an acre, in which he started by showing the local farmers how to cultivate the local Hibiscus sabdariffa and later other vegetables such as Corchorus olitorius, Brassica oleracea, and Lactuca sativa. Later on, more lands were given for vegetable farming as shown in Figure 6.7, until everyone had a plot of land on which to farm whichever vegetable he was interested in.

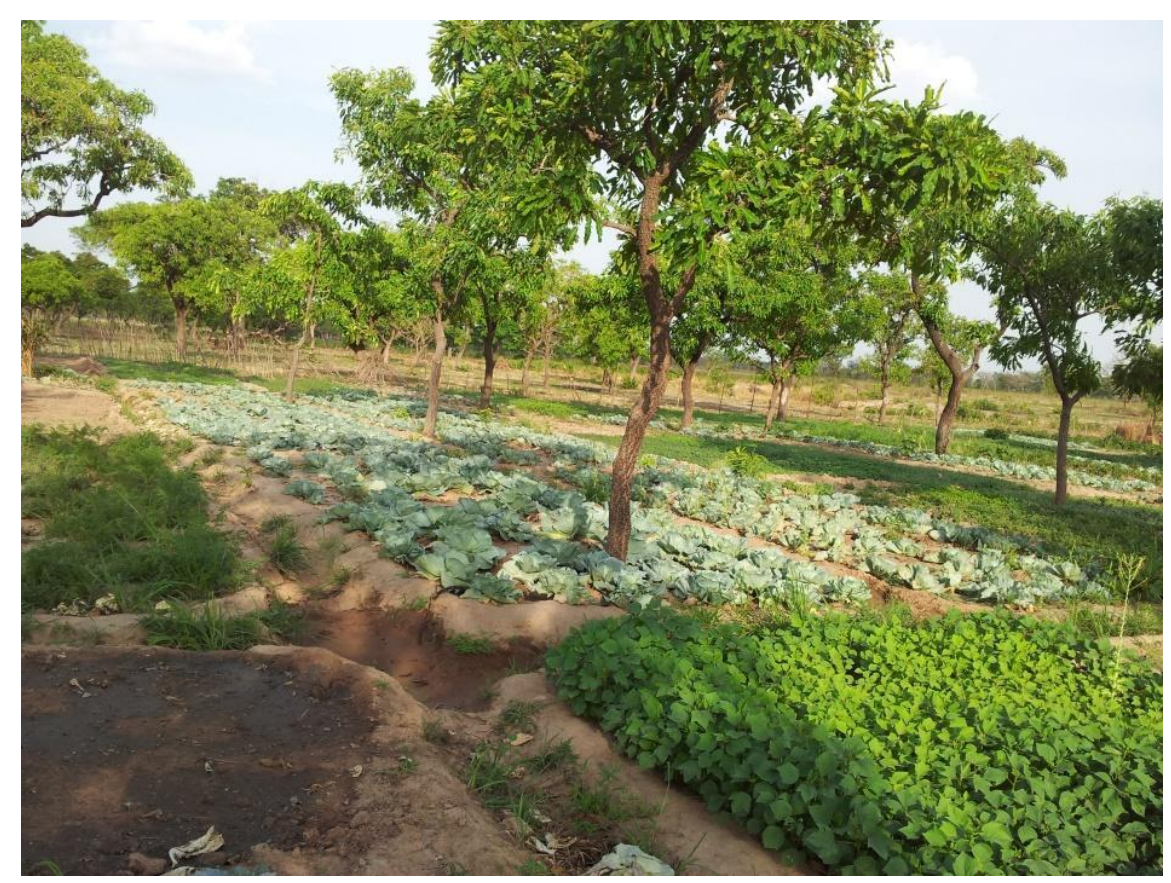

Figure 6.7: Vegetable site in Sahapalegu

Source: Author's fieldwork, 2015

Here, the access point to land was through religion- the meeting in the Mosque. This religious tie was solidified by a common tradition which facilitated the meetings with the elders and subsequently the chief, who authorised access to land for dry season vegetable farming. In this section, we see the importance of religion and ethnicity as tools used by farmers to access communal land in peri-urban areas where the notions of tradition still play a major role, since development and urbanisation have not overtaken these areas. Saleman's specialised 
knowledge of dry season vegetable farming, its practice, market and capital requirements also paved the way for his access to resources in this area for farming. The knowledge he had placed him in the right position to access the resources he needed to continue vegetable farming. I refer to such emerging farmers from the city as supervisory or expert farmers.

\subsubsection{Land access through non-governmental organisations}

During the baseline survey, I took part in a focus group discussion with women who farmed at the Social Security and National Insurance Trust (SSNIT) vegetable site. I was surprised that the farmers on this site were all women, as most farmers on the other sites I had visited were men. During the focus group discussion, one of the participants mentioned that her husband had been farming on this site for about two years during the rainy season. He was approached by the land owners, the NGO ActionAid, who had privately acquired a lease on this land.

ActionAid met our participant's husband farming on their land informally, a practice which is not unusual on undeveloped private and government lands in Tamale. They asked him if he could put them in touch with women who were interested in dry season vegetable farming. ActionAid's approach to the farmer was linked to their programme to involve women in agriculture. This programme was informed by recent calls from international organisations like the Food and Agricultural Organisation (FAO) for NGOs to consider gender equity in resource access through a gender-sensitive agricultural system. The farmer agreed to ActionAid's request and later brought 12 women including his wife whom he said showed interest in this farming practice.

There is no dugout or reservoir on this site; the only water source is a standpipe which was installed by the Urban Agriculture Network (Urbanet), which works together with ActionAid. Urbanet is a non-governmental organization that aims to help build the capacities of smallholder farmers, especially women, to combat food insecurity in situations of landlessness and climate change. Urbanet gets most of its funding from ActionAid Ghana to carry out its projects and activities. For the first three months, Urbanet paid the water bills at this site and permitted the female farmers to grow and sell any vegetable of their choice so they could gather enough money to start paying the next water bills. Only indigenous vegetables are produced at this site - Hibiscus sabdariffa, Corchorus olitorius, Amaranthus spp, and Vigna unguiculata.

Here, I have shown the importance of interpersonal relationships at the community level, where access to land depends on one's interactions and connections within the community. This is especially relevant in a society like this one, where information deemed important by those in power is passed and acted upon mostly by males due to the patriarchal nature of the society. That is why a man is asked to search for women interested in vegetable farming, and women are not picked out from the vegetable growers' union, for example, and asked to recommend other interested colleagues. I would like to stress here that investments 
in social relations, as we saw in the preceding examples, are central to virtually all other elements of access, as purported by Berry $(1989,1993)$. Figure 6.8 features female farmers farming on irrigation site, which is a new trend which I will further explain in this chapter and Chapter 7.

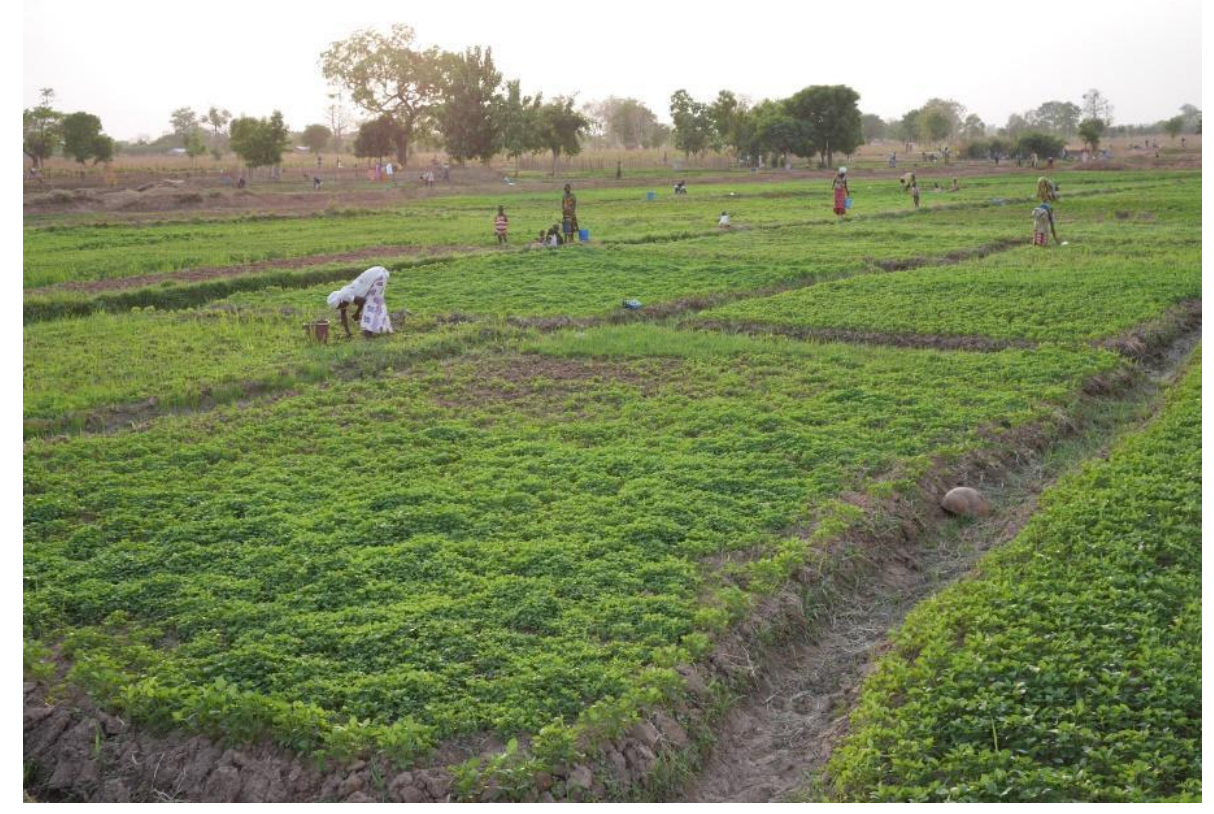

Figure 6.8: Female farmers at Golinga irrigation site

Source: Author's field work, 2015

International Non-Governmental Organisations like the United States Agency for International Development (USAID) with other national non-governmental organisations have created mechanisms through which women get access to lands directly for dry season vegetable farming. This has been done through discussions with irrigation chairmen and officers, who have intended educated and sensitised male farmers on these irrigation sites on the benefits of asking their wives join them. At the Golinga irrigation site, men have refused to have their women farm on the same plots of land with them but have agreed that their women be given plots of land at the edge of the irrigation site. The plots of land at the edge of the irrigation site are farmed exclusively by women even though insufficient. This practice also takes place at the Bontanga irrigation site in a slightly different manner. Women are permitted to only weed or harvest from their husbands' farms. The reason given to men to allow their wives, sisters and/or mother-in-laws to have a separate plot of land to farm is to encourage agronomic benefits from organisations that encourage gender sensitive agricultural practices.

Focus group discussion with women at the Golinga irrigation shows that women were given separate plots of land to farm as a group, as seen from the quote below: 
One day, the chairman organised a meeting with us the women in the community and told us that some visitors came to talk to them that they want the women also to be added to those men who are doing farming. Male farmers have an association and the organisation (visitors) also want to see women's organisation, so that was the reason why they called us to introduced the farming to us so we can also join them on the farm... for about six to seven years now, we started errh farming ourselves.

Some of the benefits of letting women have their own separate plots of land to farm will include external organisations investing more on these irrigation sites through: advancing the technical agronomic knowledge of the farmers and providing them with more improved seeds and inputs, especially during field day activities or demonstration days. These trials will then take place on the plots of expert farmers chosen by the irrigation officers or chairmen. The interactions between farmers and Non-Governmental Organisations comprise what I have termed exchange-oriented relationships. Farmers and non-governmental organisations exchange different services, and their interests are sometimes met during these exchanges mediated by the irrigation authorities.

Here we see how international discourses promoted by certain agricultural bodies at the global level have led to changes in the agricultural policies and programmes of government agencies and non-governmental organisations, with effects on local agricultural practice and resource access rules. Through this discourse, international organisations have gained legitimacy in the international agricultural development circle as pro-poor agents promoting land access for vulnerable and marginalised people in the community. The State and Non-Governmental Organisations also benefit from this discourse by positioning themselves as promoters of gender-sensitive agricultural practices with the need for funding. The shifts in agricultural policy and programmes in support of gender sensitive farming on irrigation sites have led to new resource norms for women, as they now have direct access to private plots, a situation which conflicts with former norms about women's role in customary land usage.

\subsubsection{Accessing land through rental arrangements in irrigation sites}

From interviews with irrigation officers at the Bontanga irrigation site, I gathered that Bontanga irrigation reservoir was built around the 1980's, but cropping only started in 1987. This irrigation site presently covers about 450 acres. This reservoir site was compulsorily acquired by the government for irrigation purposes with no compensation paid to the chiefs. The crops grown here are mainly rice and vegetables. Access to land in this irrigation site was divided 
into three categories. These categories were labelled A, B and C. Those allocated land under category A were those affected most by the construction of this dam; they were individuals farming in the main area where the reservoir was built. Those allocated land under category $B$ were those who were farming within the catchment areas around where the dam was built, and the last category, C, was for anyone interested in farming in this reservoir who came from outside - that is, those from Tamale, Savelugu, etc. Plots of land were allocated through a land allocation committee which was set up and supervised by the Ghana Irrigation Development Authority (GIDA).

Under this scheme, farmers were given plots separated by different water ditches and a leader was selected from each block or area to head Farmer Based Organisations (FBOs). From these FBOs expert farmers were chosen and taught how to technically assist the irrigation officers in joint management, partly due to many government irrigation workers being made redundant. This means that the technical capacity of the expert farmers heading these FBOs was strengthened, as they monitored water use and distributed water supply to different laterals and blocks on a weekly basis.

Land access rules on this site state that when a farmer gets tired of farming or is old and wants to retire, he is expected to return his plot of land back to the irrigation body known as GIDA who will reallocate it to another farmer on their waiting list. From interviews with irrigation officers, it was clear that this rule was never adhered to, as practically all farmers before retiring trained their children or relatives to farm on their land, in the expectation that they would inherit it. Here we see how farmers are resisting the state governance system and introducing an alternative one on this site, which resembles the traditional usufruct land rights, where lands are inheritable. Farmers are opting for usufruct land rights instead of the state governance system because this aligns with their interest in accessing and maintaining use of farmland. The change in governance system on lands in irrigation sites has indirectly encouraged family farming. This is in contrast to communal lands where families are now being evicted from the lands they farmed on, which are being reallocated by chiefs to estate developers, as explained in Chapters 1 and 5.

A newcomer can now only gain access to plots of land in the irrigation site through informal means since all plots of land are occupied. To gain access to a plot of land on this site, one needs to build a chain of social relations. Information about available plots travels through word of mouth from farmers who have land or are cultivating on this site to others who are interested in renting land for farming. From interviews with farmers at this site, I gathered that when an individual is interested in farming, he generally gets information on the availability of a potential plot of land for renting from a friend, colleague or family member. When information is passed on about available lands, the new farmer makes a choice. Then an introduction is arranged between him and the plot owner so that they can come to an agreement on 
the rental rules relating to the plot of land he is interested in. This agreement will entail an agreed sum given to the landowner as rent for the plot of land and also another amount set aside for water provision at this site, which is usually fixed by the irrigation authorities but fluctuates depending on the landowner, who might increase this fee. Many migrants from Bakwu, a community in the Upper East region, rent plots of land at this site during the dry season to cultivate onion.

I was informed by a land (plot) owner 22 , that he gives out his land only to farmers who promise to enrich the soil during the farming season. He stated that for one to continuously have access to his plot of land, you had to maintain the fertility of the soil. He explained that if the soil is well taken care of, the rainy season crops will yield better. When a plot of land is rented out on this site, apart from the land rent and water fee which he is expected to pay to the landowner, the tenant has the opportunity to obtain fertiliser, marketers, and machines like tractors and combine harvesters at a subsidised rate using the name of the plot holder. The money for inputs is usually given to the plot owner, who pays for the requested services under their name, through which the one who rents the plot of land benefits. So if a plot owner is not happy with a tenant's agricultural practice on his plot he can easily delay this process to get the tenant to comply with his preferences. During another interview, a plot owner said he bases his decision on whether to give out his land depending on the crops the tenant wants to cultivate. He also mentioned that different agreements are reached depending on which vegetable is to be grown. He said he prefers renting out his land to tenants willing to grow pepper or onion, but onion is the best because the quantity of fertiliser user to grow it will still be active in the soil during the rainy season when he grows maize or rice.

Access to land also depends on the financial capability of the one looking for land. From my interview with migrant farmers, they spend roughly 80 to 145 Ghana Cedi on renting an acre of land per season and are expected to pay an additional 20 Ghana Cedi for water charges. Those who cannot afford these fees enter another arrangement with the landowners (plot owners) where they do not rent the land but farm and share the proceeds with the landowner. This system is similar to the sharecropping system of abuna and abusa, found in the Southern part of Ghana. The difference is that the rules of sharing are not strict like those in the South where the landowner gets $50 \%$ or a third of the crops. Here the tenant will agree on a certain amount to give the land owner after selling the crops and subtracting all his expenditure. In another case, the tenant will take out his expenses and the money left over will be

22The landowner refers to a person that owns plot(s) at the irrigation site and sometimes rents some out to migrants. 
shared equally. Here a capitalist market system has been co-constructed with the state governance system to form a hybrid system, where a lively land rental market flourishes despite being prohibited by the state. The role of the market is strong in this example.

From the examples above, it is clear that farmers have come up with various strategies to access land for vegetable cultivation. These access routes have been forged through social relations with friends and family in the community and individual land owners:

1. Belonging to a clan (ethnicity); have a religious affiliation

2. Having knowledge of the markets

3. Raising capital through social relations and networking with non-governmental organisations

These examples are reflected in Ribot and Peluso's (2003) definition of access as the 'ability' to derive benefits from things. The above routes shape how resources are gained and controlled. Land access, as we saw, also depends on financial capital and specialised knowledge about soil fertility measures, which is a form of maintaining access to resources by influencing the person who controls the resources. Access to resources is not only driven by economic and moral claims to farm, but also by socio-political and ritual activities which shape kinship and power relations. From all the examples given above, I argue that the ability to shape discursive terms has influenced the entire framework of resource access in Tamale greatly. By speaking of a 'global commons' international Non-Governmental Organisations and other actors mentioned above have successfully created universal categories and naturalised their interventions around the world under the guise of women's rights in agriculture and sustainable resource management. In this way, resource access has been shaped to produce categories of power and knowledge, creating a new trend in women's rights to land in Northern Ghana (Foucault, 1978).

In this section, I have dwelt a lot on how land can be accessed through different routes using data from five different sites. In the next section, I will focus on how water is accessed, since having land without water for irrigation in the dry season is useless. I will explain how water rights in Northern Ghana are operationalised and how farmers gain access to water for their vegetable production.

\subsection{Water rights in Ghana}

In Chapter 1, I generally explained the different water rights found in Ghana and the Northern Region in particular. Here, I intend to discuss how water rights are operationalised in urban and peri-urban Tamale by farmers as they engage in vegetable gardening. Data about how water is accessed in this study will triangulate information provided in the above section on different strategies used by farmers to gain access to land and, in later sections, to seeds. In Tamale, when a farmer is looking for land for farming he makes sure there is a water source 
from which he can access water to irrigate his crops. Water scarcity is a problem in Tamale, with pipe-borne water usually rationed within the different quarters in and around Tamale so everyone can have access to water, especially in the dry season. The people of Tamale rely mainly on surface water for domestic and agricultural purposes as the ground water table is low (Gyasi et al., 2014). Piped water is mostly used for domestic activities like drinking, cooking, washing and commercial functions, while water from dugouts and canals is mostly used for domestic and agricultural activities.

As a reminder, rights to water as a resource in Ghana are pluralistic -- that is, there are customary and statutory rights relating to water use and management. According to customary laws, water is owned by all in the community but controlled by the chiefs and elders. In addition, a landowner with water on or close to his plot has the right to use this water source and others in the community can request permission from him to access the water (Eguavoen, 2008). According to statutory laws, on the other hand, the Water Resources Commission (WRC) 1996 Act vests all water ownership in the state, which is authorised to issue administrative water rights or water licenses. Sarpong (2004) has made it clear that even though there is no legislation in place to deal with contradictions of water rights between customary and statutory law, this is not a problem, as domestic water users do not require a license. It is stated in Articles 9 and 10 of the Water Resources Commission (2001), that "any water use resulting from the abstraction of water by manual means is exempted from these regulations." The scenario explained above is valid when "use for any purpose where the abstraction level does not exceed five liters per second." This claim of public ownership over water does not restrict local users from accessing water; it only regulates this access depending on the type of water resource (Sarpong, 2004).

In 2014 Gyasi et al. (2014) claimed there were 91 mini-reservoirs in Tamale. Many reservoirs and dugouts in Tamale have been built and rehabilitated by the state and nongovernmental organisations with assistance from the communities (Namara et al., 2011). For example, the International Fund for Agricultural Development (IFAD) through the Land Conservation and Smallholder Rehabilitation (LACOSREP) Projects I and II constructed 90 small dugouts in the Northern Region. Plan Ghana, the Red Cross, and ActionAid have also been involved in dugout and reservoir constructions since the 1970's. In addition, between 1995 and 2009, more than 200 small reservoirs were constructed in Ghana, with about 80 in the Northern regions. The International Fund for Agricultural Development (IFAD) together with Africa Development Bank (AfDB) have plans to invest a further US\$30 million in building or rehabilitating an additional 50 small dams in the three northern regions of the country, according to Venot and Cecchi (2011). GIZ as of 2009 had rehabilitated 28 dugouts in the Northern 
Region with intend to fund the rehabilitation of 60 dugouts in this region, according to regional news from the Modern Ghana website ${ }^{23}$.

These dugouts and reservoirs were meant to act as an alternative source of water for domestic purposes, agricultural activities and livestock watering. Reservoirs and dugouts are used as a source of drinking water, as one-third of the population of Tamale does not have access to potable water, according to Gyasi et al. (2014). The control and maintenance of these water sources are under the jurisdiction of the Community Water and Sanitation Agencies (CWSA) as well as local authorities in the different communities. Even though most wells are privately owned, their use is, in fact, open to all as one only has to ask for permission politely before fetching water. This is because water is still perceived as a public good. This notion of non-exclusion of individuals in the use of water for domestic purposes is a characteristic of most semi-arid environments, as detailed in Cotula et al. (2006). The Ghana Water Company is charged with the provision of potable water for domestic and commercial purposes in urban areas, as opposed to the CWSA, which works more in peri-urban and rural areas.

Even though water is still a basic resource, access to it sometimes relies on tools such as pumps and buckets. Table 6.1 shows that different water sources exist in the different open vegetable sites in Tamale. I will use five of these different sites as examples to explain the different ways in which farmers access water to irrigate their dry season vegetable fields.

Table 6.1: Associated water sources on open space vegetable sites in and around Tamale

\begin{tabular}{|l|l|}
\hline Open space vegetable sites & Main water sources \\
\hline SSNIT & Pipe borne water \\
\hline Dufa & Dugout \\
\hline Dugu & Stream \\
\hline Jekeriyili & Gutter \\
\hline Datoiyili & Stream \\
\hline Fuo & Gutter \\
\hline Bontanga & Reservoir \\
\hline Golinga & Reservoir \\
\hline Tuunayili & Gutter \\
\hline Gurugu & Pipe borne water \\
\hline Gnasco & Dugout \\
\hline
\end{tabular}

\footnotetext{
${ }^{23}$ https://www.modernghana.com/news/200279/gtz-rehabilitates-dams-in-northern-ghana.html. Retrieved on the 9.11.2016.
} 


\begin{tabular}{|l|l|}
\hline Buipela & Reservoir \\
\hline Choggu & Dugout, pipe borne water \\
\hline Sahapalegu & Reservoir \\
\hline Sangani & Spring \\
\hline Gumbihini old dam & Pipe borne water, well \\
\hline Gumbihini new dam & Pipe borne water \\
\hline Gumbihini waterworks & Gutter \\
\hline Fooshegu & Reservoir \\
\hline Kabonayili & Shallow well \\
\hline Zagyuri & Stream, ditch, well \\
\hline Nyanshegu & Gutter \\
\hline
\end{tabular}

Source: Author's fieldwork, 2014/15

\subsubsection{Accessing community water}

Many vegetable sites are found close to dugouts and reservoirs. Some of these reservoirs which were built by the state have been rehabilitated by international organisations like GIZ, for example, the Fooshegu reservoir. This reservoir is meant to provide water for domestic uses such as drinking and cooking, and also for agricultural purposes like vegetable irrigation and livestock watering. Most of these reservoirs and dugouts are filled with runoff water during the rainy season and are mostly contaminated by coliform bacteria, making them unsuitable for domestic and even agricultural purposes except when treated, which is rarely the case (Cobbina et al., 2010). Most of these water sources are owned collectively by the community which implies that anyone from this community can have access to and use over this water for any purpose as long as it does not heavily pollute the water for other users. Farmers in Fooshegu, Choggu, Sahapalegu and other sites access water used for their agricultural practices for free because they are considered members of the community.

In recent years, with population pressure and urbanisation, water is becoming scarce, especially in the dry season, as competition for water increases between different water uses. Increased dry-season vegetable cultivation is competing with other water uses, especially domestic purpose usages. If a farmer is not part of a community but owns land on its site, access to water is free. So, access to land is intricately linked to access to water. Most of the farmers farming around reservoirs, streams and gutters use water pumps more often than watering cans due to the long distance from the water source to their farm plots. To reduce cost and labour, many farmers in different sites have pooled resources together and bought water pumps for irrigating their vegetables. For example, some of the farmers in Fooshegu are of the same descent, and so their farming activities are more like a family business. They pooled their resources together and bought some farm inputs, including a water pump. Other farmers 
without a water pump can borrow and use it for free but are expected to fuel it. Water pumps have become a necessity amongst farmers growing vegetables as a commercial activity rather than for subsistence.

In this section I have shown how social and cultural identity opens up routes of access to community water, which in this example are considered as a common property good. This example ties with the ideas in 6.1.1 and 6.1.4 where not only interpersonal relations, but also identity become integral elements through which resources can be accessed by farmers. Due to the fact that water in the site is a public good, there have been continual conflicts over water between domestic and agricultural users, especially when the water dries off towards the end of the dry season. It is due to this problem of water competition between different water users that Non-Governmental Organisations such as New Energy have approached farmers with the proposition of reducing these conflicts through the introduction of technological innovations, which will be discussed in section 6.2.4 below.

\subsubsection{Access to pipe borne water}

The Gumbihini area has two reservoirs, and farmers have cultivated around these reservoirs for many years. In 1989, one of the reservoirs situated uphill burst and destroyed the other reservoir in a downward flow of water. The two sites around the former reservoirs presently do not have any body of water, so farmers are finding alternative water sources for irrigating their vegetables in the dry season. The Gumbihini farming area is divided into three; the Gumbihini old dam, the Gumbihini new dam, and the Gumbihini waterworks or former VRA. Farmers in Gumbihini old and new dam sites have negotiated with Non-Governmental Organisations over the years to have access to different water sources for irrigation. The farmers in Gumbihini old and new dam started off by building wells and shallow dugouts. These wells and dugouts could not satisfactorily meet the water needs of many of the farmers.

The farmers at Gumbihini old and new dam later negotiated with a Non-Governmental Organization, the Urban Agricultural Network (Urbanet) and a researcher at the University for Development Studies (UDS) in the person of Mr. Halim to get pipe water installed in their sites to irrigate their vegetables. The agreement was that Urbanet and UDS will arrange with the Ghana Water Company (GWC) to install water pipes and the farmers will pay monthly bills as they use this water for irrigating their crops, as shown in Figure 6.9. 


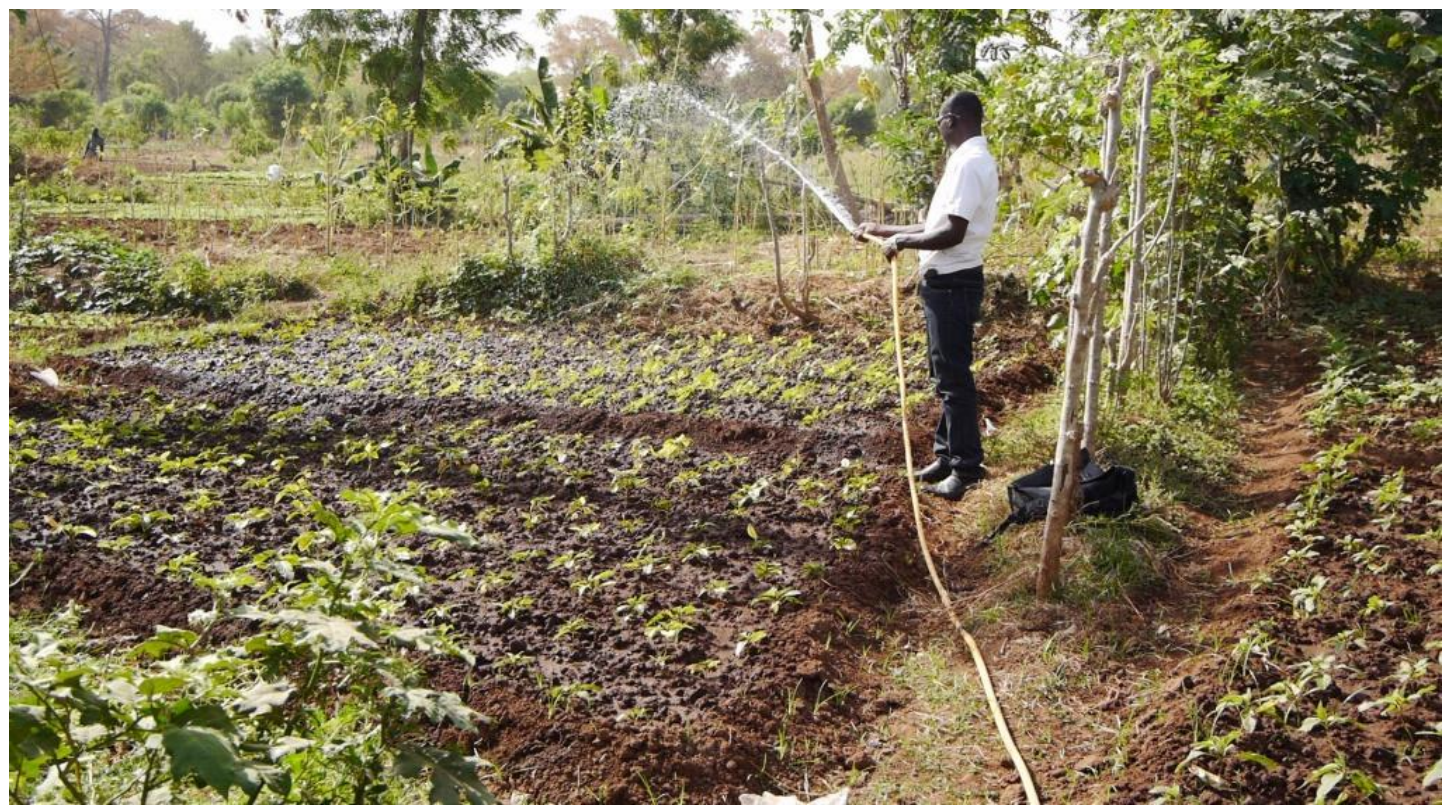

Figure 6.9: My field assistant is helping a farmer to irrigate his Amaranthus spp with pipe-borne water at Gumbihini new dam

Source: Author's fieldwork, 2015

Farmers' acceptance of using pipe-borne water was also a strategy used to sway public opinion into accepting that not all farmers use dirty water in growing their crops. Farmers had picked up this discourse from Urbanet, who used the World Health Organisation water standard as a benchmark for any good quality water, and pipe borne water by GWC meets this standard. The use of piped water was meant to clear up concerns about health risks and instill faith in consumers that urban farmers were meeting good hygiene standards. Public concern over the quality of irrigation water used in vegetable farming became pronounced as a result of a radio campaign, which took place after a cholera outbreak in Tamale. During this campaign, farmers were accused by the public during radio talks of using dirty water in producing vegetables consumed raw and in so doing putting consumers' health at risk. The change in health discourse introduced by farmers to alter public opinion on the quality of water used for vegetable farming was facilitated through their collaboration with a non-governmental organisation.

Here, farmers have been able to sway public opinion through their cooperation with civil society as a forum through which they have gained access to clean water for vegetable production. They have also used media outlets as fora to counter claims of health risk by saying that vegetables are healthy and that water concerns have been addressed. Non-Governmental Organisations have legitimised vegetable farming as an important livelihood strategy, contributing to good health and food security. Simultaneously, civil society has also 
gained credence as an efficient and fundable organisation that genuinely has the will to address the health concerns of the urban population. These two organisations gained credence from the public and this has boosted the reputation of agriculturally led civil societies in the country.

In the Gumbihini new and old dams, the Urban Agricultural Network (Urbanet) encouraged farmers to organise themselves into groups of eight to be allocated a metered water point. The installation of water pipe connections succeeded in the Gumbihini old dam area, which is flat, but was problematic in the Gumbihini new dam area, which slopes, causing water pressure to be low. This meant that farmers with plots uphill had difficulties accessing water and so they planted crops like Jute mallow (Corchurus olitorious) which retains water and can survive the first few months of the dry season, after which their farming season is over. In addition, most of the farmers in Gumbihini new and old dam made it quite clear through interviews that their crop choices are influenced by the water fee that they have to pay. They said they cultivated fast-growing vegetables like amaranth (Amaranthus spp) in order to earn money with which to pay their water bills and other slower growing crops like lettuce (Lactuca sativa) and cabbage (Brassica oleracea) to take care of household needs and other expenses.

However, in the Gumbihini waterworks area, water for irrigation is gotten from a gutter/ditch which receives its water from a car wash point upstream and from a broken pipe of the Ghana Water Company. This means that water is always present in this site even during the dry season. From interviews, I was made to understand that when there is a water crisis, the communities around get water from this gutter for domestic purposes. This competition for water has prompted farmers to seek ways of maintaining their access to this water source. For example, to reduce competition from other water users, farmers leave the waterway dirty to discourage its usage by the community, when there are water shortages, and also use sandbags to block the water in one place for easy irrigation as shown in Figure 6.10 below.

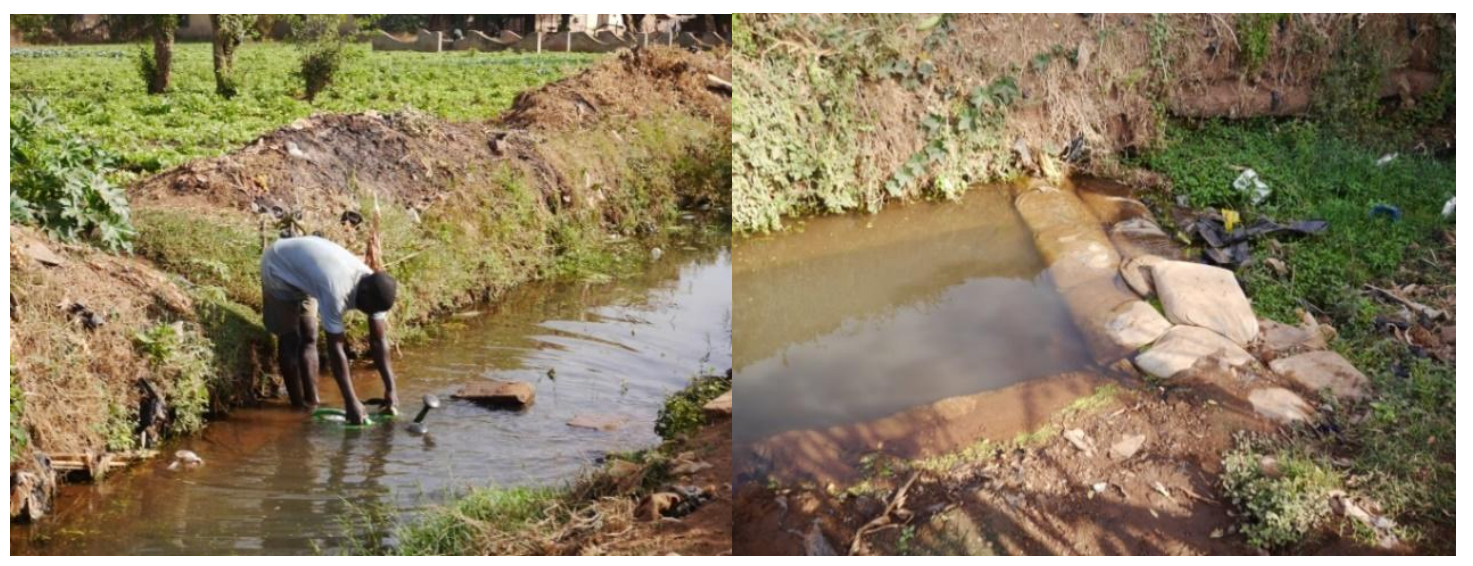

Figure 6.10: Water source at Gumbihini waterworks

Source: Author's fieldwork, 2015 
A microbial study on water source and vegetables produced on this site conducted by Cobbina et al. (2013) reveal that faecal coliform bacteria (E. coli, Strongiloides stercoralis, and Ascaris lumbricoides), on vegetables and water were well above the World Health Organisation's (WHO) recommended standard for wastewater used in irrigating vegetables. This high level of faecal coliform bacterium could be attributed to the farmers' strategy to reduce water competition during the dry season, by leaving dirt in the water. During the last stages of my field work, the farmers' union was cooperating with an Italian cooperative from the province of Trento, the district assembly and the local agricultural unit on a project to rehabilitate the Gumbihini new dam reservoir and channel clean water to this vegetable site and others, as will be explained in the case study in Chapter 7 . This project was still in the final stages of the agreement, but it is not yet certain when it will take off.

In this example, actors do not simply choose one institution over another to serve their interests, but they engage with multiple institutions concurrently, creating hybrid governance systems. This process simultaneously serves the interests of the civil society realm, as it is portrayed as a strong institutional partner for positioning urban agriculture as an integral survival livelihood strategy in urban space. This example shows that the process of gaining access to land is more complex than a simple switch from one existing mode of governance to another.

\subsubsection{Access to stream/ well and sewage ditch}

Zagyuri is situated in the Northern part of Tamale; where farmers grow vegetables on government land belonging to the Kamina army barracks. The main source of water used for irrigation in this site is sewage water from the barracks that flows into a shallow stream dividing the site into two. The fresh water in the stream usually dries up in the dry season, but the sewage water is always available because the soldiers at the barracks use water in their daily activities. During the very dry spells, water from the barracks is blocked off by upstream farmers with bags of sand so they can have enough water for irrigation. When this happens farmers downstream will have to negotiate with those upstream so water blocked is opened at certain times for them to also access water for irrigating their vegetables.

The practice of accessing this sewage water for vegetable production has come under criticism from many quarters, including the vegetable farmers' union, who wants to maintain their status as providing clean, healthy and good quality vegetables. The media has influenced consumers and public opinion, by stating that vegetables from this site are detrimental to health, especially after the cholera outbreak. Also, herders in surrounding communities complain that dry season vegetable gardening affects their livelihood negatively. This happens when animals eat crops on farmers' field and so are killed by farmers. 
Even though vegetable farmers still rely on this water source as their main source of irrigation, they had contacted the District Assembly for an alternative source of water to no avail. According to information from a focus group discussion with the farmers on this site, when the Metropolitan Assembly did not respond to their request, New Energy stepped in and built two wells, as shown in Figure 6.11, from funding provided by WaterAid Ghana.

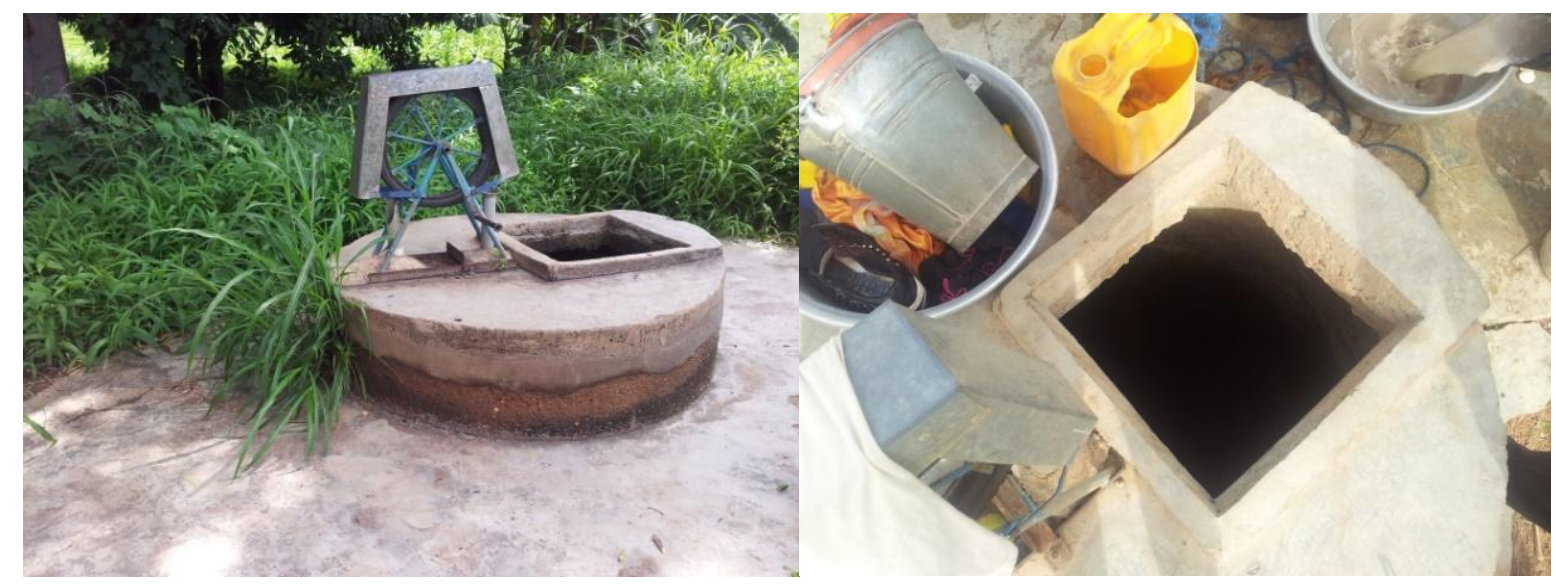

Figure 6.11: Well installed by New Energy in Zagyuri vegetable site

Source: Author's fieldwork, 2015

Over time the mechanised pumps on these wells have broken, and no repairs have been made by any of the actors involved in their use or management. This means that farmers who use these wells have to carry water manually, which is labour intensive. As a result of this, many farmers prefer to fetch water from the sewage ditch and stream because they are shallow and so less taxing to get water from. Other farmers have become innovative by creating canals through which water from the sewage ditch is directed to their fields while the wells are mainly used now for cooking, drinking and washing clothes and vegetables for sale. Vegetables cultivated on this site are primarily indigenous because exotic vegetables have not performed very well on this site. The vegetables grown here are Corchorus olitorius, hibiscus sabdariffa, and Amaranthus spp., which are usually cooked before consumption and not eaten raw.

Farmers here have defended their use of waste water as a response to the failure of the government to provide them with safe water for vegetable production. The absence of a state governance system in this site has created a space within which non-governmental organisations are legitimising their claims for funding as agents of local development, as already argued in section 6.2.1 and 6.2.2. Farmers have also shifted the discourse of health risk inherent in the use of wastewater for irrigating vegetables to the health benefits of consuming indigenous vegetables, which are nutritive and risk-free if not eaten raw, as explained in Nchanji and Bellwood-Howard (2017). Farmers attempt to enroll consumers into their network 
through changing health discourses has failed, so they sell their vegetable in the guise that it is from the libga irrigation and not Zagyuri.

In the above section, we can see that it is not enough to have water for irrigation; the quality and source of water also determines the type of vegetables grown. For example, in Gumbihini new and old dams, exotic and indigenous vegetables are grown due to the constant presence of pipe borne water, compared to Zagyuri where only indigenous vegetables are cultivated due to the presence of wastewater. Farmers in Zagyuri revealed during a focus group discussion that they are aware of the health risks associated with growing exotic vegetables with sewage water, but that wastewater has no health hazard implications for consumers if vegetables are prepared well. Farmers themselves eat these vegetables and claim that their good health shows it has no health risks.

\subsubsection{Access to water through technology}

Fooshegu and Datoiyili are situated in southeastern Tamale. Farmers in these sites have access to water from both a reservoir and stream respectively. These water sources are considered public and so free for everyone to use for any activity of his or her choice. In the late dry season, there is always competition for water between domestic users and agricultural users, as noted in other examples already discussed in section 6.2.2. This contest over water use and management is one of the reasons why some farmers from Fooshegu moved to Datoiyili in search for land and water to cultivate vegetables. The scarcity of water in the dry season is not a new phenomenon in Tamale, as mentioned above. New Energy, a non-governmental organization, solicited funds from the United Nations Development Programme (UNDP) and the Ghana Energy Commission, to provide farmers in Fooshegu and Datoiyili with solar powered irrigation facilities for vegetable gardening, as shown in Figure 6.12. This project, according to New Energy, aims to reduce conflict between different water users and engender sustainable use of water through drip irrigation. The introduction of this technological innovation was still in the pilot stage when my fieldwork came to an end.

Here, as in sections 6.2.1, 6.2.2 and 6.2.3, civil society organisations are dominating the agricultural development stage, as they take advantage of the limited state control in urban agricultural systems to co-construct new or hybrid governance systems in urban food systems. Their activities are further made legitimate through their alliances with other international organisations that fund their activities and make them relevant in international development circles. The interactions between farmers and national and international organisations show a new trend of governance, where local NGOs are empowered by the international community to situate themselves in the community as an alternative service provider in place of the State. This global trend taking place in the urban agricultural sector is what Ferguson and Gupta (2002) refer to as transnational governmentality, as discussed in Chapter 2. With transnational 
governmentality, civil societies do not replace the state or usurp state control or authority, but they are accorded a space within which to serve the people through a process I have termed 'state-civil society autonomisation.' Through this process, governance becomes a process for all and not just the State, as individuals and civil societies become accountable to discipline themselves (Rose, 1996).

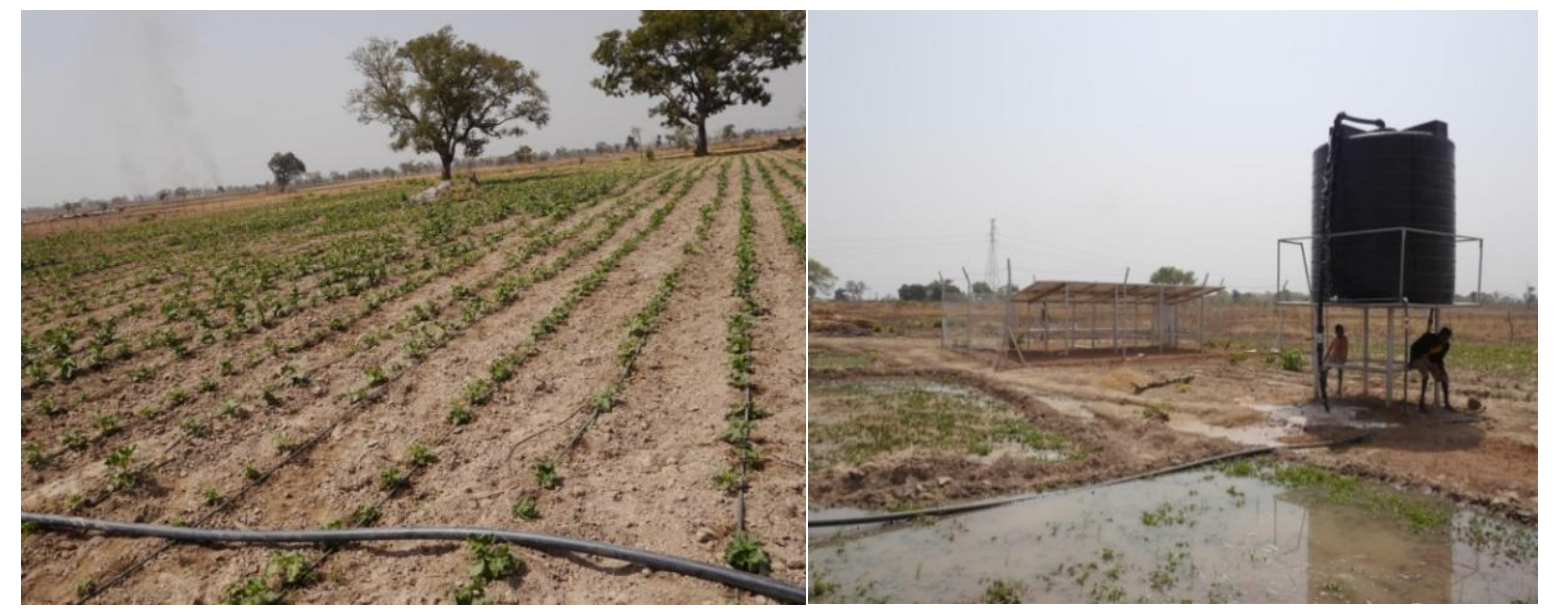

Figure 6.12: Solar powered and drip irrigation facilities in Fooshegu and Datoiyili Source: Author's fieldwork, 2015

\subsubsection{Access to water through farmer's innovation in Kabonayili}

Kabonayili is situated in the Northeastern part of Tamale with a seasonal stream used for vegetable farming. This stream, unfortunately, dries up mid-dry season, and farmers either stop farming or find alternative methods to irrigate their vegetable gardens. For example, they carry water in jerry cans from the nearest standpipe to irrigate their crops. Farmers' choice of crops to grow is influenced by the availability of water in the dry season. Mainly climate resistant vegetables like Hibiscus sabdariffa and Corchurus olitorious are cultivated here. They generally will be planted around October and harvested around December/January before the stream dries up.

In-depth interviews with a farmer on the site reveal that his interest in farming vegetables on this site started after he witnessed the drilling of a well around a nearby children's home, the SOS Children's Facility, by experts with machines. He observed that the area chosen for the well was so wet that one of the machines got stuck. When a hole was drilled on this land, no water surfaced, which is not surprising as many water drills in Tamale are unsuccessful (Gyasi et al., 2014). The farmer then decided to experiment by digging a shallow well to see if he could obtain any water, since water did not surface from the deep well. The farmer's innovativeness paid off; as he successfully got water in the shallow wells he dug. On this farmer's field, many shallow wells like that shown in Figure 6.13 can be seen during the dry season, which he uses to irrigate his vegetables. Over time, the farmer has expanded his 
vegetable farm, after he understood that water seeps into his shallow well from the sides and not from underground. This new innovation has spread to Fooshegu where farmers, to reduce competition over water with domestic users, are also digging shallow wells to irrigate their crops, before the introduction of the solar powered irrigation plant.

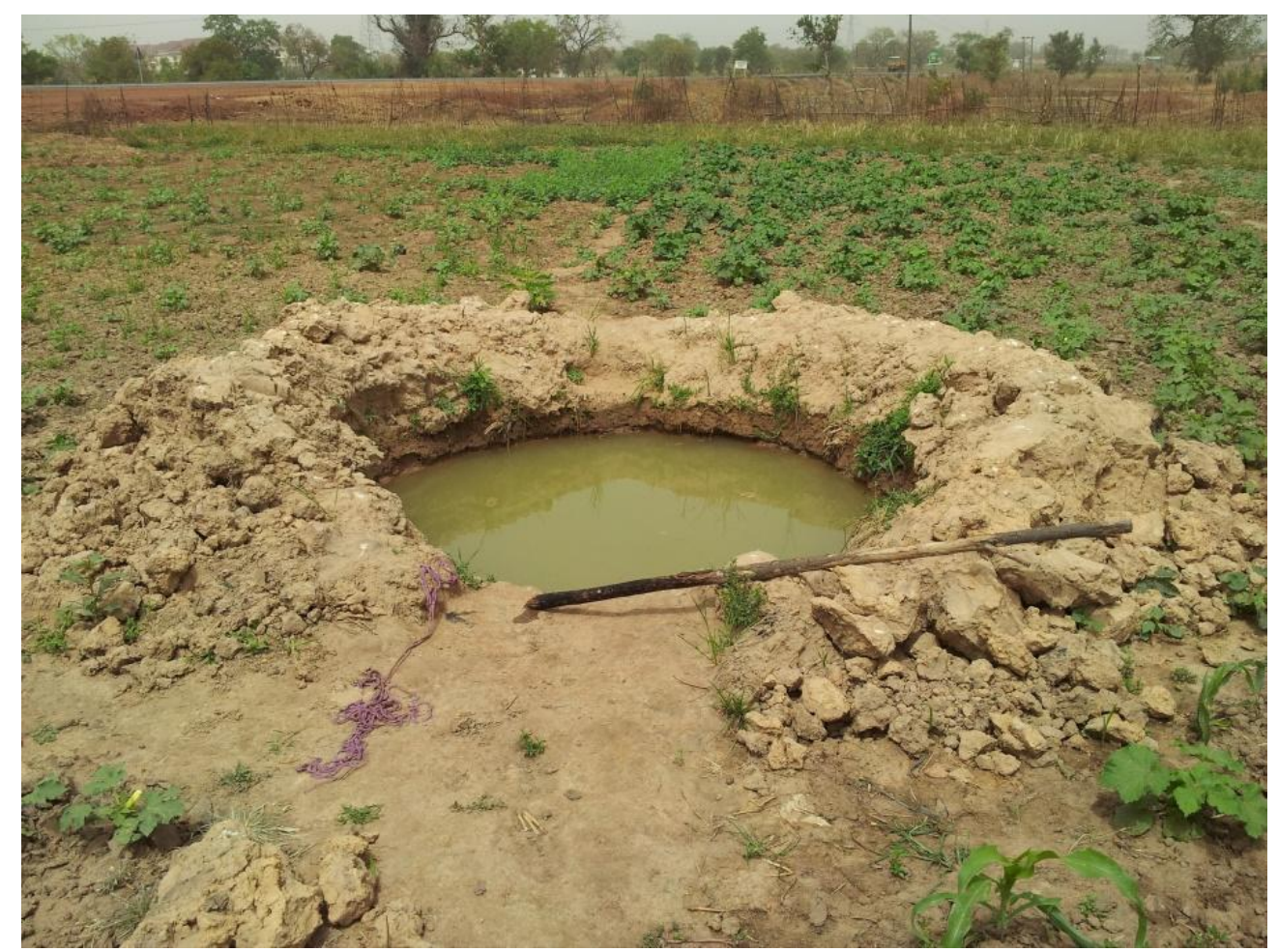

Figure 6.13: Hand-dug shallow well in Kabonayili

Source: Author's fieldwork, 2015

In this example, we see how technology is used as a tool to ease access to water for vegetable gardening, as was explained for other sites in sections 6.2.1, 6.2.2, 6.2.3 and 6.2.4. Farmers generally use technologies that cost little in comparison to their finance and labour resources, but NGOs have made high-cost labour reducing technologies available to farmers at no additional financial cost by subsidising them. These technological packages have been used by NGOs to enrol farmers into their network and maintain their legitimacy and relevance in local governance or development.

Cotula et al. (2006) have shown that the rights over land and water intersect and overlap in many ways, as explained in sections 6.1 and 6.2. I have also argued in this section, as I did in section 6.2, that technology, identity and religion shape how farmers gain access to resources. I have also shown how actors, in choosing different strands of laws and norms which suit their interests, have created new and sometimes hybrid governance systems. Furthermore, I have explained how Non-Governmental Organisations have legitimised their activities by enrolling farmers into their networks through technological packages. The produced 
knowledge from these activities and practices have also given NGOs greater legitimacy in policy circles and among local resource users. Access to seed is critical for any agricultural activity, and its importance cannot be overemphasised. In the next section, examples of how farmers access seed will further reinforce the arguments already made about how land and water are accessed in section 6.1 and 6.2.

\subsection{Seed Rights in Ghana}

Seed was described as the fundamental unit of any production system in Chapter 1. There exist two main seed systems in many African countries, a formal and an informal system, as is the case of Ghana. The formal seed system is state-led but supported by International NonGovernmental Organisations (INGO's) with strict procedures on how seed should be produced and distributed, where the market plays an important role. The informal system, on the other hand, is a traditional system where farmers are the main decision makers on how seeds are produced and distributed, with the market playing little or no role. According to McCann (2011: 1), the "agricultural history and the history of seeds in sub-Saharan Africa are intertwined and are an aggregate effect of individual day-to-day decisions by farmers." The seed industry is plagued by many contestations, as revealed by political ecology literature on seed systems in Ghana and Africa (Afari-Sefa et al., 2012; Amanor, 2010; Amanor, 2011; Ayana et al., 2014; Scoones and Thompson, 2011; Tansey, 2011).

Many vegetable farmers rely on mainly on their own saved seed or seed secured through informal networks. These saved seeds are sometimes referred to as unreliable in terms of quality, quantity and tolerance/resistance to pests and diseases by the state or agricultural-led non-governmental organisation as stated in Niangado (2010), but are readily available to farmers due to the fact that it can informally be accessible and most of the times are free. Informal seed systems have remained dominant despite government laws and policies to formalise them. According to Louwaars et al. (2012), an integrated seed system will make seed policies more coherent with farmers' practices. The seed policies in Ghana concentrate more on the provision of seeds for cereal crops, rather than vegetable crops, a trend in many African countries as multiplication of grain crops is emphasised in relation to narratives of food security. In the next section I will explain the formal and informal routes through which farmers get access to seed for vegetable gardening.

\subsubsection{Formal sources of seeds}

Farmers access seeds from informal and formal sources. Formal sources account for about $20 \%$ of seeds used for crop production (Louwaars et al., 2012). In this section, I will explain how farmers access seeds from research labs and educational facilities and also from agro- 
dealers. The data on the processes of access will triangulate information provided earlier in the ways farmers gain access to land and water.

\subsubsection{Access to seeds from research labs and educational facilities}

The Savanna Agricultural Research Institute (SARI) over the years has worked towards providing small-scale farmers with what they see as the appropriate technological options and crop varieties depending on their production system. According to the Savanna Agricultural Research Institute (SARI) Director, little work has been done on vegetable seed provision as compared to cereals, a trend which is dictated by available funding from the government or international organisations. Recently, SARl's plant breeders have worked with the University for Development Studies (UDS) to come out with new indigenous vegetable varieties adaptable to this agro-ecological zone. A participatory variety selection workshop was organised by UDS and SARI to which dry season vegetable farmers in Tamale were invited. During this Participatory Variety Selection (PVS) phase, farmers were given the opportunity to select the plant varieties they liked and explain why they preferred them. Criteria used by farmers in this exercise include standard genotype criteria such as plant vigor, architecture, yield, harvesting frequency, viscosity, taste, color, drying quality and marketing potential.

The Participatory Variety Selection process "enable[s] farmers to identify genotypes they preferred as well as traits that are critical to end users" (Sugri et al., 2015: 468). When farmers are done with the PVS exercise, the plant breeders will go ahead to produce a foundation seed ready for an informal release. According to the formal seed system, these seeds are to be given to seed growers to produce certified seeds for sale to agro-dealers, NGOs or directly to farmers, under the supervision of the Inspection Division of the Ministry of Agriculture (MoFA). In this particular case, the seeds were given to farmers directly for community seed production without them being registered or certified, which is presently accepted under the formal seed system, as shown in Figure 6.14. According to the Director of SARI, after the President of Ghana promulgates the new seed law, the distribution of unreleased seed varieties to farmers might become impossible. Farmers are presently still receiving new and unreleased seed varieties from SARI and other non-governmental organisations. This practice has been criticised by seed companies and others actors in the agri-seed business who believe that farmers should have access only to certified seeds formally released for use. This is because if farmers are allowed to use their saved seeds continually then the market for registered seeds will be too low for any profits and private investors in this business will be in a deficit ${ }^{24}$.

\footnotetext{
${ }^{24}$ Read Amanor (2010) and Amanor (2011) for a detailed case of the different actors with vested interests on the cereal seed production system.
} 


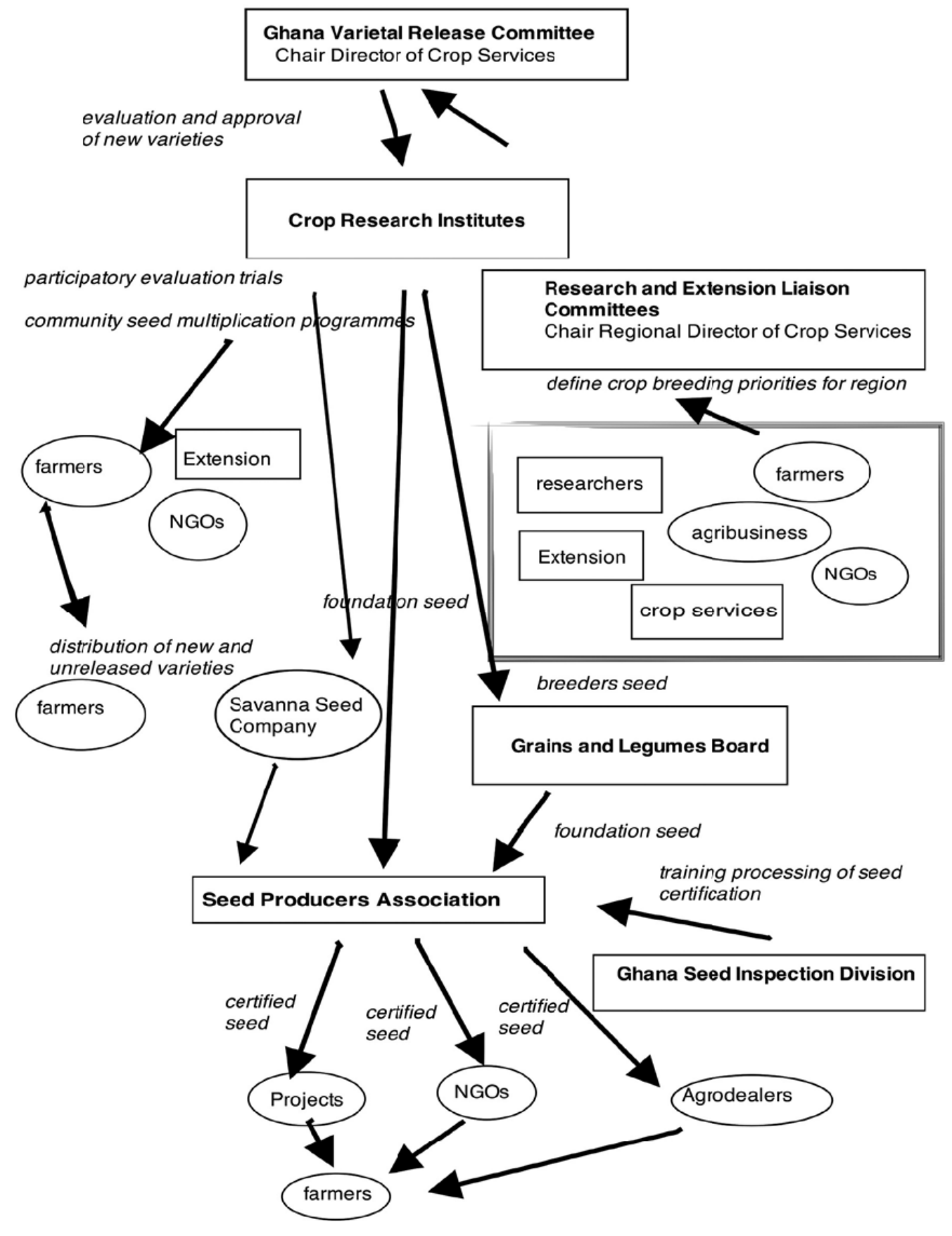

Figure 6.14: Actors and institutions involved in the production of certified seed at the regional level in Ghana

Source: Amanor, 2010

\subsubsection{Access through agro-dealers}

From interviews with farmers in Tamale, the two most frequented agro-dealer shops are Wumpini and Ganoma. The reason farmers patronize these shops is that they generally have stocks of vegetable seeds, even when they cannot be found elsewhere in Tamale. In addition, farmers have built personal relationships with these agro-dealers over time in the course of their agricultural practice. These agro-dealers, I was informed, have staffs that are prepared 
to visit farmers' fields when they are called on the phone about the ineffectiveness of any chemical or the presence of diseases or pests. They also organise local field visits with suppliers' representatives once or twice in each planting season to advise farmers on their agronomical practices and to advertise their products. These agro-dealers have also purchased air time at the Justice and Savannah radio stations, where they get agricultural extension officers from the government or non-governmental organisations to advise farmers on good farming practices unique to this region. During these programs, some minutes are allocated to advertise their products, and also opportunities are given to farmers and the general public to call in with questions. Furthermore, Wumpini organised joint workshops with the Urban Agricultural Network to educate farmers on the importance of using the 'right' seed. These different and constant means of communication between farmers and agro-dealers builds their relationship and keeps it on a good footing.

In 2014, a new agro-dealer shop known as Technisem was opened in Tamale, adjacent to the Gumbihini new dam site. This agro-dealer was convincing farmers to buy improved open-pollinated and hybrid seeds varieties from his shop. Farm or field day demonstrations were organised and farmers given improved open-pollinated and hybrid seeds for free to plant alongside their own crops. Farmers were told to compare later the yield and physical properties of their crops with those given by the agro-dealer to see if there were any differences or similarities. The idea behind this strategy is that if the improved variety seeds perform better than the local seed, farmers will be convinced to pay for these improved seed varieties from the agro-dealers shop. From interviews, I gathered amaranth (Amaranthus spp), sweet pepper (Capsicum), and jute mallow (Corchurus olitorious) had been provided free to farmers in more than five vegetable sites in Tamale, and they were asked to indicate this on the field with a sign as depicted in Figure 6.15 below. 


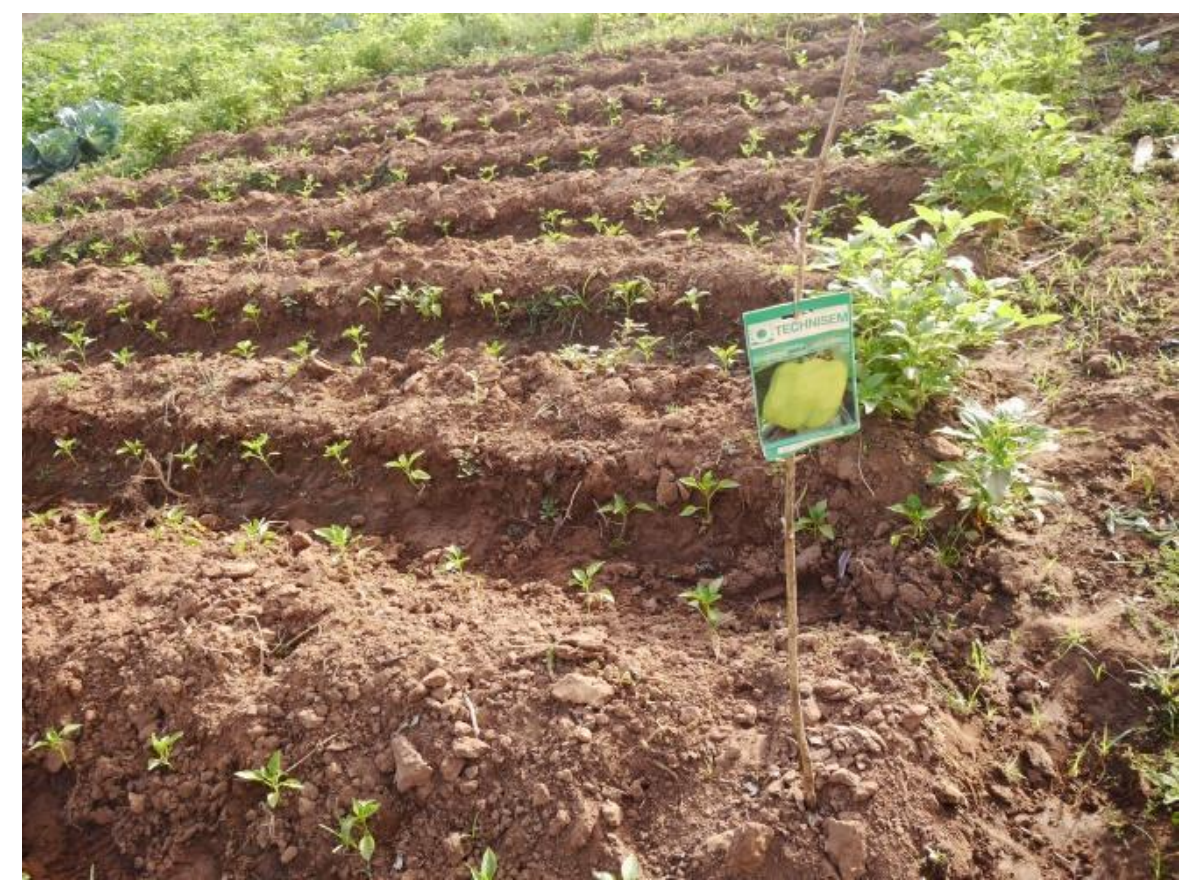

Figure 6.15: Improved sweet pepper variety beds in Tuunayili

Source: Author's fieldwork, 2015

In interviews with farmers in Gumbihini new dam and Tuunayili, I was informed that this agro-dealer advised them to pin the packet of the seeds on a stick. These sticks are then placed on the ridges where they planted the improved varieties so that later it would be easy to differentiate the improved seed variety ridges from those with saved seeds or seeds bought from the market. Agro-dealers are promoting the idea of agribusiness and also MoFA is instilling in the farmers the catch phrase 'agriculture as a business' in order to get farmers into their commercialised seed network. This technological intervention in the form of free seed distribution is used by agro-dealers to convince and enrol farmers to use improved seed varieties, thereby buying into the global seed discourse. An enormous literature has been written on the seed debate, but this is not a major focus of this thesis. The major objective of this work is to examine resources in general, and the seed debate is merely introduced to triangulate the data provided on access to land and water and to confirm agricultural patterns of agricultural resource access. Though farmers get access to free seeds during field trials organised by agro-dealers, they can rarely afford to buy them for themselves. Here again, as in the land rental example, markets play a major role. In the next section, I will explain how farmers gain access to mainly saved seed. 


\subsubsection{Informal sources of seeds}

As explained above, informal sources account for main sources of seed for vegetable gardening. In this section, I will explain how farmers access seeds from relatives, colleagues, market women, researchers and NGOs.

\subsubsection{Friends, relatives, and colleagues}

Farmers may obtain seeds free of charge from relatives and friends. At other times, farmers are expected to return the seeds given to them in the next season. Many farmers solicit seeds from their families and relatives because they do not want to have seed transactions with market women who also provide this service. Apart from asking for seeds, some farmers negotiate for informal loans from their friends or relatives to buy seeds and pay back after the sales of their vegetables in the field. Other farmers prefer to give money to their colleagues to buy seed for them, especially if it is known that the colleagues' seeds have a high germination rate. These arrangements are usually through purchase at the seed grower's home or in the local market. As long as the farmer believes the seed grower's seeds are of good quality and cheaper than certified seeds in the market, he will continue to buy the seeds.

This is the case with lady's finger (a variety of okra) which, according to interviews amongst farmers who grew okra, was best accessed from seed growers at the Bontanga irrigation site. They explained that certain renowned farmers in Bontanga got the seeds during an experimental trial and had been reproducing these seeds for sale. This seed is highly sought after due to its many desirable characteristics; it matures early, it can be harvested multiple times compared to the local variety, it is easy to pick due to its short stature and the fruits are smooth, making harvesting easy. During an interview with an okra farmer, he said he got to know about this unique okra variety after observing it grow on a colleague's farm. He later approached this colleague to get information on how to access this particular seed. He further mentioned that negotiating with a colleague to buy a 'good' seed is common amongst farmers, especially if the colleague is growing that seed.

In this example, we see how farmers gain access to seed through social relations with kin and colleagues. Seed transactions between kin and colleagues are often referred to as informal transactions. Farmers are also influenced in part by what they see, and not only relationship ties. For example, if a seed germinates and yields well on a colleague's field, then a farmer seeing this will go in for that same seed. This shows that informal interactions are very effective ways of disseminating information and knowledge between farmers. It is for this reason that other actors, such as agro-dealers, are also organising field day activities with farmers in which seeds are distributed for free, and farmers are left to conclude after germination and harvest about which seed variety is better, as will be explained below. In the next 
section, I will explain how markets are embedded in resource access in exchange-oriented relationships between farmers and market women.

\subsubsection{Market women}

Market women generally buy vegetables from farmers at the farm gate and sell directly to customers or retail them at the market. They are structured institutions with defined rules and regulations on how they function in the market ${ }^{25}$. Some farmers rely on market women to provide them with seeds. Seeds may be provided through a loan request to purchase seeds, payable after the vegetables are sold, alternatively the market women may gain a monopoly over the farmer's field over the exchange of seeds. During interviews with farmers, I gathered that seed transactions are carried out with market women because farmers believe they have a sound knowledge of seed performance through their long experience in dealings with other farmers. Market women usually have different agreements with various farmers for how a seed can be acquired from them, and these agreements vary depending on the individuals or type of vegetable involved. In some arrangements, the farmer might have to sell his produce to her exclusively until the debt is paid, after which point he can sell to anyone he desires. If the farmer acquired a loan to buy seeds from a market lady, he might negotiate to pay at the end of his vegetable sales or let her harvest vegetables which amount to the loan given. Market women have also become gatekeepers over farmers' produce, as they control access to it. This is because many farmers sell their vegetables at the farm gate and not the market.

Usually, to keep the market woman as a customer and credit source, farmers create a cordial relationship with her based on trust and goodwill. This is done by giving her extra vegetables for free every once in a while, as a form of appreciation and as a strategy to encourage her to come back to buy from them in times of plenty and scarcity. The market woman is also notified when the vegetables are ready for the market. These communications have been facilitated through the use of mobile phones. In my interviews in Datoiyili, some farmers expressed disappointment about their seed transactions with market women. They complained that when a market woman provides a farmer with seed and succeeds in gaining a monopoly over the farm, the farmer will always suffer losses.

In this example, trust-based social relationships and financial availability influence farmers' access to seeds, as demonstrated in previous examples. Farmers also access seeds through their relations with individual researchers and non-governmental organisations.

\footnotetext{
${ }^{25}$ More information on the role of market women can be accessed from Clark (1994), who talks on the how activities of market queens shapes the market dynamics in the Kumasi central market in Ghana.
} 


\subsubsection{Access through researchers and non-governmental organisations}

Farmers often rely on researchers and Non-Governmental Organisations to provide them with seeds. This is usually done on an individual basis when researchers visit farmers in their fields to discuss with them the types of vegetables they grow. In one of my vegetable sites, the farmer showed me packets of hybrid seeds which a researcher had given him to grow. The improved hybrid seeds given are mostly vegetables which the farmers have experience growing. Here we see how a researcher uses his access to capital (grant money) and authority (usually from the government or an external organisation) to convince farmers and get them enrolled in his experimental networks, which he will use to produce knowledge and to gain legitimacy in policy or academic circles. Farmers also use historical recollections or past stories of how they accessed certain improved seed varieties to request the same service from new researchers, especially those working in international projects.

In other sites, like Gumbihini, farmers gain access to seeds from Non-Governmental Organisations and individual researchers, who use their cordial relationship with the farmers to get them enrolled in the Latourian sense in farm trials on their fields. This is usually done by the researchers to see the potentials of new seed varieties and write papers on these activities to remain relevant in the science world. These actors' tactics of choosing farmers to further academic interests are what I refer to in Chapter 2 as a shopping forum. Such a forum is 'shopping' for actors that validate it as an institution by using them as an arena in which to resolve their scientific disputes. It may collaborate with other actors and institutions in this search to gain legitimacy in its scientific field. Farmers in this site also use their connections with researchers and non-governmental organisations to gain access to workshops and projects which seek expert farmers, through which they gain knowledge and finances to further their agricultural practice.

\subsection{Conclusion}

In this chapter I have shown how farmers gain access to land, water, and seed for vegetable production, and also how they can be constrained in accessing these resources. Resource access is conditioned by social relations. Understanding the multiplicity of ways in which these social relations work is key to understanding the complexity of resource access. As discussed above, wealth, technology, social identity and market relations shape how farmers gain access to resources. These elements do not have a fixed way of aiding one access a resource. Many non-governmental organisations and researchers, in their will to improve ( $\mathrm{Li}, 2007)$ on the agricultural conditions of vegetable farmers through different technological packages, are also legitimising their actions and validating themselves as social service providers for the masses (Lund, 2006). 
In the above examples, I have shown how power relations are shaped and reenacted as actors use governmental interventions to legitimise their power and authority over certain agricultural activities at the local level. Actors have also chosen one institution or forum over another to achieve personal interest but at the same time gain legitimacy from the public (Benda-Beckmann, 1981; Bierschenk and Olivier de Sardan, 2003). For example, non-governmental organisations have provided water facilities in many vegetable sites, gaining legitimacy from the public as active local development agents.

Farmers are also using the identity discourse in reinvention and retelling history to gain and maintain their access to resources, as happened in section 6.1 above. If this does not work then, they use what Lund (1998) refers to as an 'open moments,' which give an actor or group of actors the possibility of reasserting or eroding the power of another actor or institution over resource control. They do this in order to regain authority and power by renegotiations with the government and Non-Governmental Organizations to access and maintain control over these resources. If this does not succeed, conflicts erupt, and later negotiations are reestablished and power relations shift. This process is not static, but it is fluid and ever-changing.

Even though farmers have 'use rights' over land and water, for example, chiefs still have political control over these resources, because they are the ones that allocate these resources to farmers. According to Lund (1998), the situation painted above always leads to confrontations between the resource users and the politico-legal institution. Vegetable sites have become local political arenas where different institutions vie for legitimacy and subsequent power and authority as they provide public services (Lund, 2006).

I agree with Lund (1998) and Rose (1994) that the repeated intervention by the State to make clear rules pertaining to land tenure only seems to increase the existing ambiguity and unpredictability of land access. The move towards unambiguous clarity brings about a counter movement for "exceptions, fluidity, imprecision and uncertainty" (Lund, 1998: 11) and confrontation between the resource users and politico-legal institutions, as well as among the resource users themselves and also politico-legal institutions themselves. The different examples on how to access land, water, and seeds for vegetable production have shown that access to resources goes beyond disputes over resource use but integrates issues of control, law, and politics. 


\title{
Chapter 7 - Maintaining and Controlling Access to Re- sources
}

\author{
"Some people and institutions control resource access while others \\ must maintain their access through those who have control" (Ribot and \\ Peluso, 2003: 154).
}

\section{Introduction}

As previously explained Chapter 7 is a continuation of Chapter 6 . The previous chapter has already outlined different processes that shape farmers' access to land, water, and seed. That is, it detailed how access to resources is gained. This chapter is a continuation of the explanation of how the resources accessed in Chapter 6 are maintained and controlled by farmers for future use. The same theories used in analysing data in the previous chapter will also be used here to reinforce the arguments made, but with reference to the longer term perspective. An extended case study will be used in situating the data within the historical and socio-political environment in which farmers not only access resources, but also maintain control over them for vegetable gardening. In this chapter, I will also examine how farmers retain their control over resources by keeping several access routes continually open over extended periods of time. Keeping access routes open entails pooling powers from many actors, shifting alliances, investing in social relations, gaining specialised knowledge, taking advantages of gaps in overlapping pluralistic systems and even using deception when the need arises.

Farmers have varying interests in land, as discussed in Chapter 1, and the extent to which they can service their interest is influenced by the traditional authorities and the State, as explained in Chapters 5 and 6 . Farmers in this study are conceptualised as resource users who, through creating trust-based relationships and networking with other actors and institutions, are able to not only gain also but maintain access to resources relevant to their agricultural activity.

This chapter will be divided into three sections, with each section focusing on maintaining access to a particular resource. I will examine how access to land, water, and seed is maintained by vegetable farmers to sustain their livelihood in Tamale, and will reflect on new methods and their theoretical implications.

\subsection{Maintaining access to land - Gumbihini extended case study}

In order to give a background to the extended case study used in this chapter, I will explain how the Gumbihini vegetable site came into existence. I will also point out the different interest 
or rights embedded in the site and how it came to be in the hands of the present 'owners/users.' All these details are relevant for a better understanding of how farmers gained access to resources and how they have maintained their access to these resources over time. The Gumbihini farming area consists of three sites; Gumbihini old dam, Gumbihini new dam and Gumbhini waterworks/former VRA, as stated in section 6.2.2.

Firstly, there is the Gumbihini old dam area which is owned partially by the state and the Alhassan family, who belong to one of the Gumbihini chieftaincy gates. Gates are different fractions of the family that have a chance of providing a new chief when an old chief dies. Thus, members of the Alhassan family have the opportunity to become chief in this area or another area of the same clan. The land belonging to the state on this old dam site once hosted the old dam reservoir, which was used by the indigenes for agriculture and domestic purposes until it was destroyed in 1989. Since the destruction of the reservoir the land has been used by many urban farmers for vegetable cultivation. Presently, pipe borne water is used by farmers to irrigate their vegetables on this site.

Secondly, the Gumbihini waterworks site is host to a dilapidated old building which belonged to the Volta River Authority (VRA) an electricity company known presently as the Northern Electricity Distribution Company (NEDCo). The land is partially owned by the Alhassan family and the above state owned electricity company, even though the Alhassan family is contesting state ownership of part of this land. Water used for irrigation on this site is from a gutter, along which flows water from a default Ghana Company Water (GWC) pipe and from a car washing point, as stated in Chapter 6.

Finally, there is the Gumbihini new dam area, which hosts some of the former office space of the Ghana Water Company. This reservoir at one point in time supplied potable water to urban Tamale and was also used for other domestic purposes and for irrigation. The 1989 disaster mentioned here and in Chapter 6 came as a result of the collapse of the walls of the new dam reservoir, destroying the old dam reservoir downstream, including buildings and properties in its wake. These sites are found on both sides of the road, about $2 \mathrm{~km}$ from the Tamale Central market, as shown in Figure 7.1. 


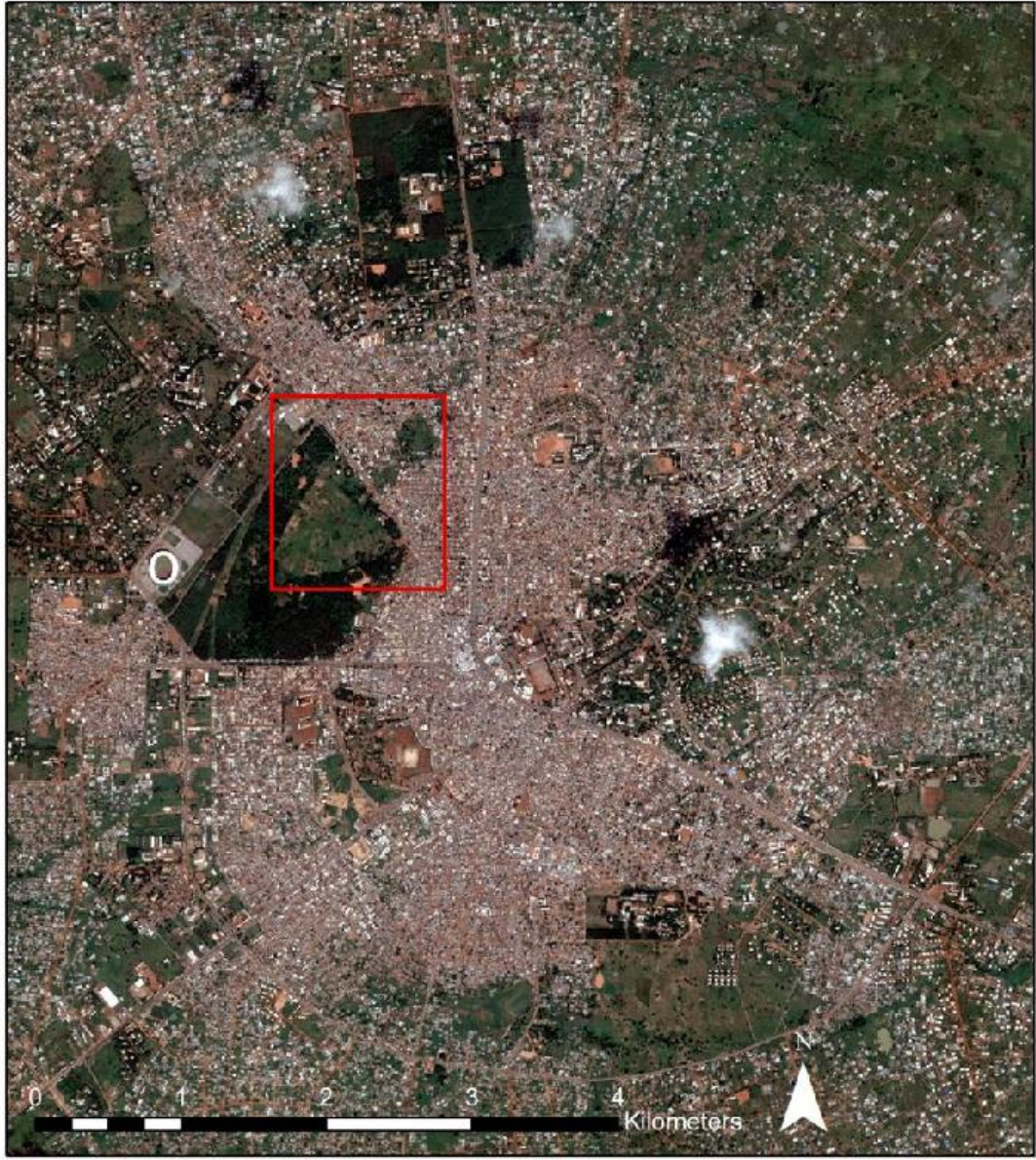

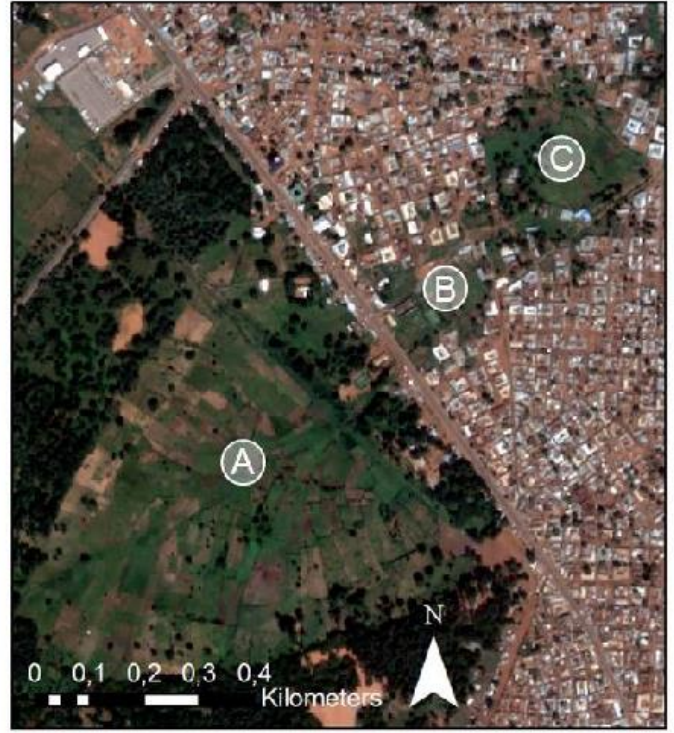

(A) Gumbihini New Dam

(B) Waterworks

(C) Gumbihini Old Dam

Data: (E) CNES 2013, Distribution Astrium Services ! Spot Image S.A., France, all rights reserved Map layout: J. Schlesinger

\section{Figure 7.1: Map showing the location of the Gumbihini sites}

Source: Chagomoka et al. (2015b)

From an interview with one of the members of the Alhassan family, known as Karim, who is the current chairman of the vegetable farmers' association, I was informed that the Gumbihini old dam area was historically 'owned' by his family, but that part of it was given to the state to build the old dam during the time of his great grandfathers. This land, he explained, was allocated to his great grandparents by the then chief of Gumbihini. His elder brother, who is the head of the family, has tried to get back full claim to this land through the courts with no success. The Gumbihini new dam area is public land, which was acquired through eminent domain by the government from the local chiefs in the early $20^{\text {th }}$ century inr order to host a new reservoir and provide water for the urban population. Lands in this site fall under the jurisdiction of three local/caretaker chiefs, which are Salamba naa, Junjuli naa and Gumbihini naa. This site includes the forest reserve area planted in the 1940's to prevent soil erosion around the reservoir. A portion of the Gumbihini waterworks area was given to the Volta River Authority (VRA) Electricity Company by the great grandfathers of the Alhassan family, that is, the then Gumbihini chief, in the 1960's. 
Over the years, the different chiefs in Gumbihini and the Alhassan family have contested government control over lands in the Gumbihini old dam site and the Waterworks site. They situate their arguments in relation to the Administration of Lands Act, 1962 (Act 123) and the States Lands (Act 125) which state that lands compulsorily acquired for public use but no longer used for the purpose they were first acquired for should be given back to the original owners. The Alhassan family head took this land matter to the high court in Accra in 2013 asking for the official return of these lands to his kind but lost the case. The case of the Gumbihini new dam area owned by the Ghana Water Company was also taken to court by two district chiefs, the Gulkpegu naa and the Sagnerigu naa, asking that the land should be returned to them, but the courts ruled in favour of the Ghana Water Company.

Many of the farmers I interviewed on these sites stated that chiefs' interest in these lands is mainly due to the personal profits they can accrue from sales of plots of land from these locations. The area of the lands in which the chiefs potentially have an interest is over 100 acres, and so potentially worth billions of Ghana cedis, especially with the lucrative land market which is now prominent in urban and peri-urban Tamale, as argued in Chapters 1 and 4. Land in Tamale is no longer acquired with just the provision of a traditional kola nut, but entails the transfer of large sums of money to the chiefs. For this reason, land allocation or land sales in this thesis will be used interchangeably, as was done in the field.

\subsubsection{Who has control over government land used for farming}

The Gumbihini waterworks, old dam and new dam sites have been used for farming for over a century now. The reservoir in the old and new dam site dam site and the gutter at the waterworks site were initially used for domestic as well as agricultural purposes before the 1989 disaster. Vegetables like Amaranthus spp, Abelmoschus esculentus, Corchurus olitorious and Hibiscus sabdariffa were cultivated in the dry season and cereals were cultivated in the rainy seasons around the banks of this reservoir and close to the gutter. Those cultivating around the reservoir and gutter were from Gumbihini and other neighbouring areas like Sakasaka and Walajari. These sites are known as some of the oldest vegetable sites in Tamale and their prominence in vegetable production has been discussed by authors such as Giweta (2011) and Gyasi et al. (2014). As mentioned, land ownership in these sites is continually contested by different actors, as shown in Table 7.1. 
Table 7.1: Contested land ownership in the Gumbihini sites

\begin{tabular}{|l|l|l|}
\hline Vegetable sites & Type of land ownership & $\begin{array}{l}\text { Actors implicated in the interest } \\
\text { on the land }\end{array}$ \\
\hline $\begin{array}{l}\text { Gumbihini old } \\
\text { dam }\end{array}$ & $\begin{array}{l}\text { Partly public and family } \\
\text { land }\end{array}$ & $\begin{array}{l}\text { Land ownership is contested be- } \\
\text { tween the Alhassan family and the } \\
\text { state }\end{array}$ \\
\hline $\begin{array}{l}\text { Gumbihini Water- } \\
\text { works (VRA) }\end{array}$ & $\begin{array}{l}\text { Partly public and family } \\
\text { land }\end{array}$ & $\begin{array}{l}\text { Land ownership is contested be- } \\
\text { tween the Alhassan family and the } \\
\text { state }\end{array}$ \\
\hline $\begin{array}{l}\text { Gumbihini new } \\
\text { dam }\end{array}$ & Public land & $\begin{array}{l}\text { Land ownership is contested be- } \\
\text { tween traditional chiefs and the state }\end{array}$ \\
\hline
\end{tabular}

Source: Author's fieldwork, 2015

This case study will focus on how farmers maintain control over the above-disputed state lands mentioned in Table 7.1. According to an interview with the Regional Director of the Town and Country Planning Department (TCPD), the Gumbihini areas had a planning scheme drawn up in 1958 by the TCPD in accordance with a request by the then-chiefs in charge of these lands. A planning scheme is a legal document that confers rights to land by specifying how this land may be used and developed. In the planning scheme, these sites were declared not suitable for residential use and were planned as a green belt or buffer zone because they were and are still prone to flooding. This meant that whoever owns these lands could not assign them to residential purposes but could use them for farming or any other activity that is environmentally sustainable.

Most farmers in these sites work alongside their sons, nephews and other relatives. They hand over their plots of land to junior relatives when they get old and want to retire. The traditional system of transferring usufruct rights to descendants discussed, in Chapters 1, 3 and 6 , is practiced by farmers in these sites. Cabbage cultivation, which has become a profitable business in Tamale, as argued in Nchanji et al. (2017), was introduced to farmers by Mr. Alhassan, a retired agricultural extension officer, in 1986. When he started planting cabbage, others saw that it generated more income, so they began cultivating it around 1991. Presently, these sites are perceived to produce the highest quantity of cabbage in Tamale, per information gained from my interviews. Their ability to produce more cabbage than other sites is sometimes attributed to the available pipe-borne water source shown in Table 6.1 (See Chapter 6). The vegetables grown here are also considered to be of high quality, since the water used for irrigation falls within the accepted WHO standard. 
Based on interviews with farmers at these sites I gathered that the Gumbihini new dam reservoir burst on 25th August 1989, on a Friday in the afternoon. The eastward flow of water destroyed buildings, properties and along with it the old reservoir in the Gumbihini old dam site. With the destruction of both reservoirs, water for irrigation was no longer available and this provided an opportunity for farmers to network with non-governmental organisations (NGOs) in getting wells and pipe-borne water for irrigation. This will be explained later in this case study.

After the reservoir disaster, the areas affected were earmarked as a disaster zone by the Metropolitan Assembly in Tamale; this solidified the ideas from the planning scheme that these lands are not meant for residential purposes. It also gave vegetable farmers the opportunity to use symbolic terms for this area which justify their farming practices on these lands. The terms used to describe these areas by farmers are "green zone," "green belt," "wet zone" or "green valley." These words were constructed to show that the activity suitable for these lands is agriculture and not buildings. People who lost their homes as a result of the disaster were relocated to Gurugu by the Metropolitan Assembly with the cooperation of the chiefs, where they were given plots of land to build houses and start life over again.

With the destruction of houses and farms in these dam sites, the land was left vacant. This event provided an opportunity for old farmers to enlarge their fields and for new farmers to move into these sites in search of plots of land to farm. Here, acquisition of new lands was actualized through cultivation. That is, one had to cultivate a piece of land to show other farmers that the land now belonged to him. To solidify their land claims, farmers constructed fences to keep others out of their land. Fences became a technology used to maintain control over plots of land by restricting the access of other actors physically, as mentioned in Chapter 2 . In addition, through the construction of fences, farmers staked their claim on a landscape indicating ownership, an element of grounding claims discussed in Chapter 2.

From in-depth interviews with Saleman, a farmer at the old dam site, I gathered that the late chief of Gumbihini naa Salifu Nabila was also a farmer in the old dam site and upon his enskinment decided to sell some plots of the land from this site to estate developers. According to Saleman, naa Nabila saw the opportunity to make a lot of money from land sales. He also complained about needing money to celebrate his enskinment and taking care of skin responsibilities. The notion of needing money for skin responsibilities is used by many chiefs in supporting their need to sell lands, according to interviews conducted at the Town and Country Planning Department (TCPD), and the same reason is given by chiefs to as to why they maintain a firm grip on control in land administration through which they can sell or allocate lands, as argued in Chapter 5 . When rumours spread, that that the chief wanted to allocate or sell plots of land at the old dam site to land developers, Alhaji Alhassan, who is an 
indigene of Sakasaka neighbourhood/ area, called the autochthons of Gumbihini to come together and fight for their land, but no one paid him heed. According to an interview with Saleman, he said: 'they each sat down idle doing nothing.' Alhaji Alhassan then sent his son Saleman to meet Prof. Abukari Alhassan, who is an autochthon of Gumbihini, an illustrious elite member of the community and presently the chief at Gushee in the Tamale Metropolis, to arrange a meeting. The reason for organising a meeting with Prof. Abukari was to consult him on the intentions of the Gumbihini chief to assign lands already used for vegetable cultivation to estate developers.

A date was agreed upon for this meeting, which was held in the absence of the other farmers from these sites. Saleman and his father met Prof. Abukari and explained the chief's position on allocating farm lands in the old dam site. Prof. Abukari said he was surprised the chief still wanted to sell off some plots of land. He said he did not really know how to approach the chief on this issue since he is an elder and his uncle, who, according to tradition, should be approached tactfully on such sensitive matters. He explained that when the present chief was to be chosen, they came together as a family and lobbied for him to get the chieftaincy position. He stated that he provided the needed finances for his uncle's enskinment, to stop him from selling land in this area to fund his new position. He also thought he had convinced his uncle to leave the lands for the indigenes who relied on them for their daily subsistence and livelihood. He also said that he had spelt out to his uncle the advantages of urban farming, through which incomes are secured and then used to send children to school and provide household needs in this neighbourhood. Therefore, if the chief sold the lands, the livelihoods of many families would be destroyed and his reign as chief would not please the people.

Saleman revealed during our interviews and informal talks that in 2005-2006, the Gumbihini chief started "selling" or allocating land in the old dam to estate developers. When he reported this new development to Prof. Abukari, he was advised by him to contact the then Member of Parliament, Prof. Waruseini or alternatively the area Assemblyman called Bagashi, a Mossi man'26, to lay out the case. Prof. Abukari stated then that he did not want to be involved deeply in this land matters. Saleman spoke to the area assemblyman who said he did not like getting involved in ethnic politics. He said if one got involved in ethnic rivalry, the chief would present a bribe in the form of a plot of land. If this bribe is refused, then the person is labeled as belonging to one of the Dagomba factions ${ }^{27}$ of either the Abudu or Adani gate. For this reason, he said he could not help in the farmer's cause. Ethnic conflicts in the Northern region have been politicised as chieftaincy matters are affiliated with either of the two most important

${ }^{26}$ Originally from Ouagadougou, Burkina Faso and cousins to the Dagomba people as explained in chapter 3.

27 The Abudu and Andani are sections of the Royal family of Dagbon which represent the two 'gates' from the which the King of Dagbon is chosen rotatory. 
or main political parties in Ghana, that is, the New Patriotic Party (NPP) and the National Democratic Congress (NDC). This has become a sensitive topic, as development projects or resource access are often said to be controlled by the ethnic groups aligned with the political party in power at different times. That is, changing political regimes affect resource access and control in the Northern region of Ghana.

The assemblyman advised Alhaji Alhassan to buy the plot of land he was farming and by so doing secure it from the 'sales' of land organised by the chief. The assemblyman also advised Saleman's father to stop fighting a "lost cause," because the chiefs will eventually sell all the plots of land on this site. Alhaji Alhassan, the Saleman's father, took heed to this advice and bought the three plots of land he was farming on. 'Selling' or allocating land implies being issued an allocation note from the local chief, which one needs in applying for a lease from the Lands Commission as illustrated in Figure 6.3 in Chapter 6. Later, the sale was termed illegal after a team was sent to the field when the receipt and allocation note in Figure 7.2 given to Saleman's father were presented to the Lands Commission for a lease. The reports came back that these plots of land are not zoned for residential purposes. This means the owner of such an allocation note cannot obtain a lease for these plots of land.

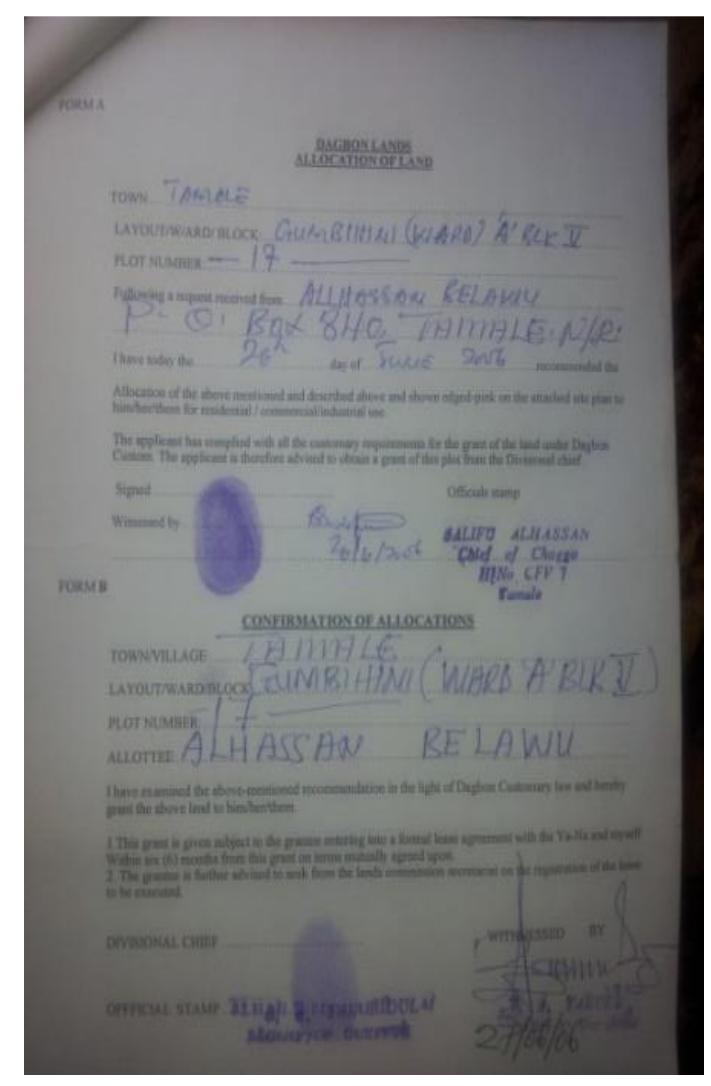

Figure 7.2: Allocation note issued for checking the validity of this plot

Source: Author's fieldwork, 2015 
Even though Alhaji Alhassan did not get a lease on the plots of land he bought from the chief, he secured these lands from any further sale by the chief. Later that year other plots of land were assigned by the chiefs to estate developers, who bought the lands and built houses. This strategy is generally used by individuals in acquiring lands for residential purposes even though they know the lands are zoned for another purpose. This strategy has been quite successful because traditional and statutory laws do not allow for illegal buildings on customary lands to be destroyed unless compensation is paid to the house owner. This gap in the law is used by estate developers to gain access to and maintain control over land meant for different purposes. Interviews at the Lands Commission and TCPD revealed that many chiefs also deceive land buyers with fake receipts and site plans to get them pay for lands which are not zoned for the purpose they want to use it for. These points mentioned above on processes of acquiring and maintaining use of land by estate developers and chiefs will be explained further in this case study.

From interviews, it was clear that land sales started at the eastern part of Gumbihini old dam, with the chief encouraging land developers to build their houses fast, giving farmers limited time to react to their farmlands being sold. This is because the chiefs realised that if a house was built on farmland, the resolution of any conflict over it would favour the house owner and not the farmer. This was after several similar cases were taken to the courts and the chiefs sometimes asked to re-allocate another piece of land for the farmer if possible. During this period of land sales, a researcher from the University for Development Studies, Abubakari Halim, was carrying out research on urban farming in Gumbihini and became aware of the many problems farmers faced in maintaining access to land. As one of the partners of the Urban Agricultural Network (Urbanet), created in 2003, Mr. Halim contacted the late Chairman of the Vegetable Farmers' Union, Wunam, to find out if farmers' plots were still being sold by chiefs. Zakaria Rashid, the coordinator of Urbanet, after having talks with Halim, and later with some farmers, decided to assist farmers to gain access to land and also maintain control over it. This technique utilised by Urbanet is referred to as 'shopping' forum (Benda-Beckmann, 1981). As explained in chapter 2 , this is when an institution decides to support an actor or group of actors achieve their goals, simultaneously gaining legitimacy for their work from the public or in local development circles. They usually approach them with a problem they aim to solve, but might succeed or not in solving this problem. The concept of shopping forum also ties in with Li's (2007a) article on Indonesian NGOs that position themselves as having the 'the will to improve' the lives of people in a community by providing them with access to resources and helping them maintain control of these. This support may or may not backfire, potentially leaving the people worse off after the intervention.

In this case study, Urbanet sought ways to assist farmers in maintaining their access to the lands they used for vegetable cultivation. Mr. Rashid, the Director of Urbanet, met the 
Regional Director of the TCPD, Mr. Sylvester, to find out what was planned for the Waterworks, Old and New Dam sites in the Gumbihini planning scheme. He was informed that these sites are green valleys, not meant for constructing residential or commercial buildings. Urbanet, with assistance from an International Non-governmental Organisation (INGO), ActionAid, gave support to farmers to buy fencing materials like wires to enclose the Waterworks and Old Dam areas; this idea of fencing was a strategy for restricting the chief's access to these lands and ground farmers' claims to these lands. This fencing symbolically shows ownership over the lands by farmers and restricts the access of land developers as well. Before the fencing wire provided by Urbanet was used, farmers had fenced these areas with sticks and fishing nets. An international NGO referred to as "Watanabi" (the name of the Japanese man who owned the NGO) had assisted farmers in the completion of a borehole they had started digging in the early months of 2000. Farmers provided labour and Watanabi took care of all the other materials needed to make the bore hole operational. With these vegetable sites fenced and water available for irrigation, Urbanet and the University for Development Studies in Tamale organised a capacity building workshop and lectures on agronomic practices of vegetable gardening to improve famers' agricultural practices.

When the chiefs realised that farmers were mobilising assistance from different organisations to promote their agricultural activity, they decide to place boundary markers (known locally as pillars) in the Waterworks area. The placing of pillars on a site, as shown in Figure 7.3, signifies that these lands are for sale. The pillar is a technology used by chiefs as a land marker to show their ownership of the land and reinforce their legitimacy as allodial right holders. Here we see how chiefs gain legitimacy through choosing a traditional system of customary land ownership which favours their agenda even though they agree that presently the land is still under government control and so not under their jurisdiction. They also rely on their legitimacy from the market as owners of property available for sale. When the good is available for the sale, the seller is constructed as the 'owner.' When the farmers saw these pillars, they had a meeting and decided to collectively remove them, disputing the authority of the chief as the rightful land owner. 


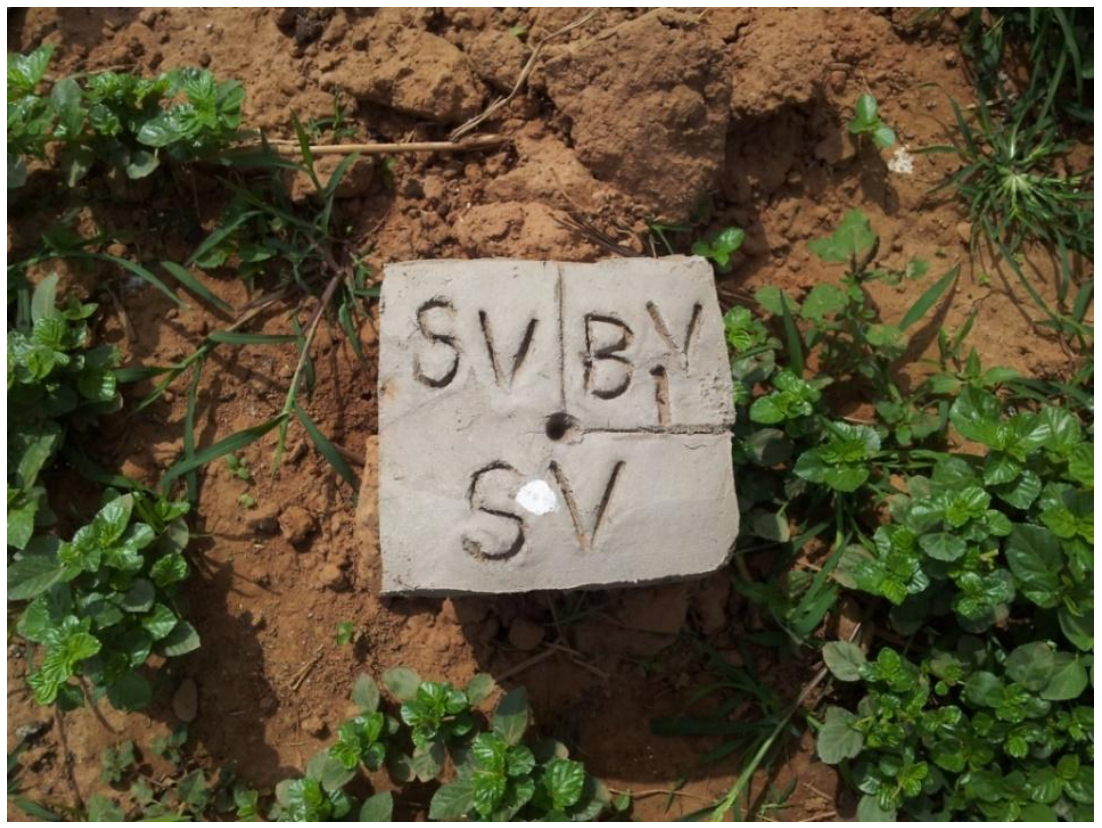

Figure 7.3: A pillar, a symbol of land ownership at the Gumbihini site Source: Author's fieldwork, 2015

The Gumbihini chief, after witnessing farmers challenge his authority by removing the boundary markers, invited Wunam, the former chairman of the Northern Region Vegetable Growers Union (NRVGU), to come to his palace in 2006. Wunam mobilised the farmers to go with him and answer the call from the chief. The meeting with the chief yielded no results, so the farmer's decided to continue their association with the civil society to maintain control over their farm land.

Another avenue used by farmers to maintain use and control over their vegetable plots was to mobilise support from senior chiefs whom they believe have the authority and power to counter the decisions of the junior chiefs. The Dagomba chieftaincy system consists of various hierarchical levels. Figure 7.4 shows how the chieftaincy institutions are structured at different levels. Chieftaincies are generally associated with towns or villages and headed by families eligible for this position. There are many levels of chieftaincy, according to Staniland (1975), of which four levels are for royalty and the last are for commoners'/court elders. The first four groups of chieftaincies are reserved for the sons of the Ya-naa's, grandsons of Yanaa's, daughters of Ya-naa's, the nephews of Ya-Naas and lastly court elders.

The Ya-naa is appointed by king makers and under his direct control are the divisional chiefs, such as the Gulkpegu naa and the Sagniregu naa, who are chosen by the Ya-naa aided by a council of elders situated in Yendi. In the case of a smaller town, the local/caretaker chiefs like Kanvilli naa, Choggu naa, Jujuli naa, Kukuo naa amongst others are chosen by the divisional chiefs. Local chiefs then choose their village chiefs and sub-chiefs. 


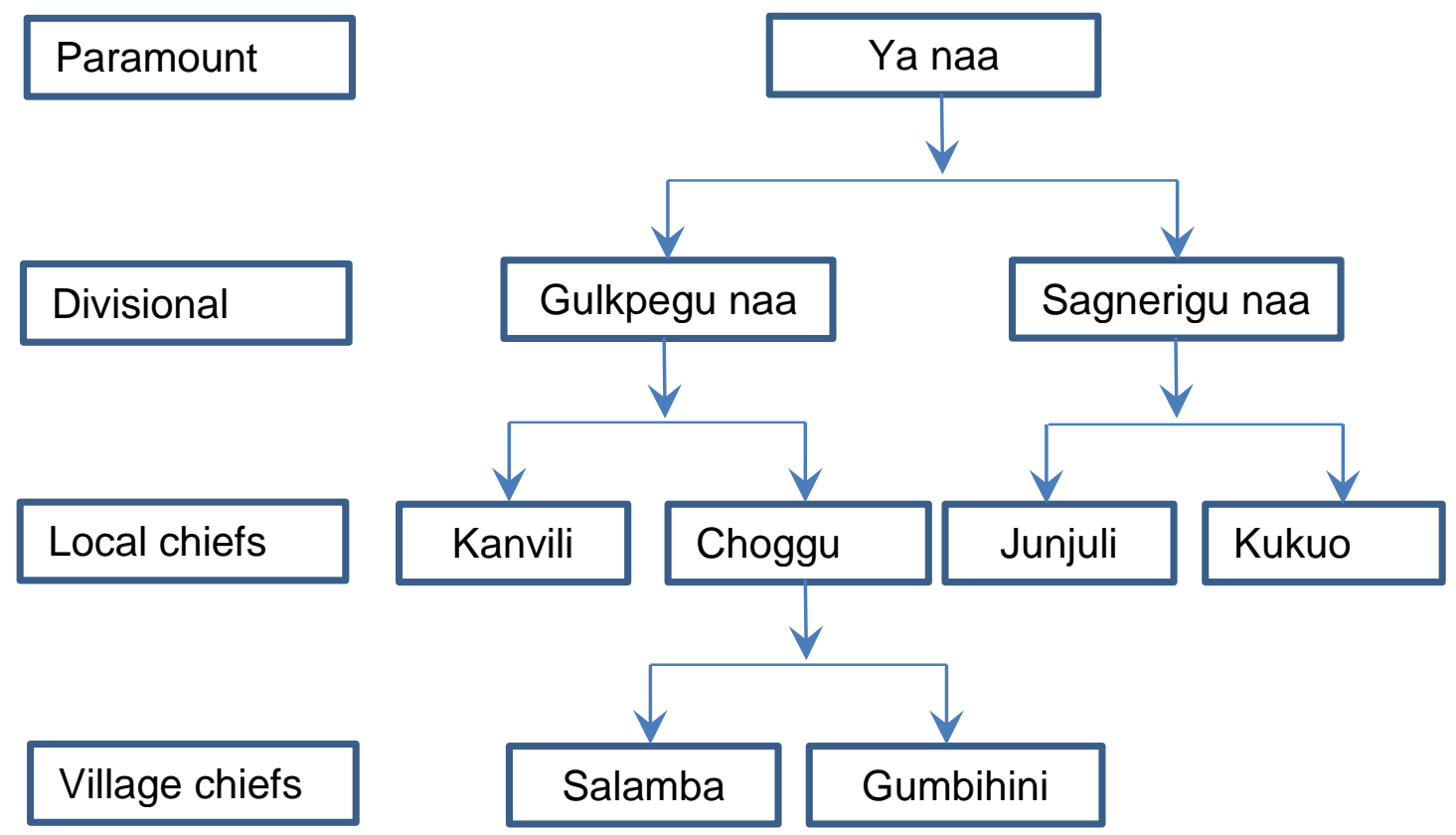

Figure 7.4: An example of chieftaincy hierarchy relevant to this case study Source: Author's construct, 2015

In respect of traditional authorities, the farmers mobilised and went to see the Choggu naa, who is a senior chief to the Gumbihini chief, to resolve the problem of land sales. The Choggu naa was not able to resolve the farmers' problem and so sent the farmers up the chieftaincy ladder to a more senior chief, the Gulkpegu naa. The Gulkpegu naa informed them that he could not directly interfere in land disputes under the control of the local chief. He stated that he can advise the Gumbihini chief but cannot dictate what he should do or should not do with the land under his control. It is important to mention here that the chieftaincy system amongst the Dagomba is one where all chiefs with land under their control are not necessarily answerable to the senior chief on how to manage these lands, but they are expected to share the proceeds of the land sales with them since officially their approval is always sought before an allocation note is issued, as explained in Chapter 6 . This implies that there exists little or no accountability on how land is managed by chiefs even in theoverall chieftaincy structure.

When the farmers discovered the Gulkpegu naa was indirectly supporting the Gumbihini chief through informal discussions with other members of the community, they carried out a protest. In response to this act, the Gulkpegu naa, Naa Nabila, took the case to the regent in Yiendi, who is known as the Kampapuya naa ${ }^{28}$. When the case went to Yiendi, the farmers

\footnotetext{
${ }^{28}$ Since the death of the King of Dagbon in 2007, a new king has not been enskinned and the regent of the dead king still sits on the skin of his father. This is because the death of the King in 2007 was attributed to a fight between the Andani and Abudu gates which has not yet been resolved. See Ahorsu
} 
do not know if Naa Nabila personally met the Kampapuya naa, but he returned stating that the Kampapuya naa had given him the go-ahead to sell the land. The farmers believed this might be possible if the regent was given false information regarding the land problem on this site through an elder bribed by the Gumbihini chief. According to Mahama (2009) and Staniland (1975), the elders who take messages to the regent are usually 'bribed' by visitors to speak well of them in any case handled by the Ya naa. This act is common in the Dagomba court and possibly in other traditional palaces in West Africa.

The farmers, not trusting the words of the Gumbihini chief, went and saw Prof. Abukari Alhassan to assist them to have an audience with the regent. He negotiated a vehicle for the farmers and selected some elders amongst them, including the present Northern Region Vegetable Farmer's Union (NRVFU) chairman - Karim. They went and met the Kampapuya naa and presented their case to him. The Kampapuya naa sent delegates to the site to survey it, and after his investigations, he instructed the Gumbihini chief to stop his plans to sell more land until the matter at hand was resolved. The Gumbihini chief refused to listen to the regent and a year later the chief decided to pursue his ambition to sell land on this site. He produced a fake letter from the Kampapuya saying that he was permitted to do so. The farmers asked for a copy of the letter and sent it to the Kampapuya for verification.

When the Kampapuya received this letter, he labeled it as fake. He was angry and wanted to know who had issued this letter on his behalf, so he summoned the Gumbihini chief and his secretary to explain the matter. The Gumbihini chief blamed his secretary, and the issue of the fake letter was laid to rest, but he still had ambitions to sell land. The Kampapuya in resolving this land issue wrote a letter to the farmers and copied the Town and Country Planning Department, the Lands commission, and the chiefs, stating that these lands should be left alone by the chiefs, as this site is not meant for residential development. The regents referred to the Gumbihini planning scheme, which gives credence to farmers' use and occupation of this site. Here the regent chose the statutory law over the traditional land law to validate the claims of the farmers.

In this section, we see how actors, institutions, and organisations choose one governing body or another from within the same institution to push their agenda. For example, farmers seek a solution to their problems from different chiefs at different levels. This strategy of choosing multiple forums within the same institutions provides legitimacy to farmers' claim over land in this farm sites. In addition, actors also pick one strand of law or norm over another in order to achieve their interests or agendas. For example, chiefs have relied on the traditional land administrative system which accords them allodial rights to all lands, laying aside the

(2014) A Poststructuralist Approach to the Dagbon Chieftaincy Crisis in Northern Ghana', African Conflict and Peace building Review, 4/1: 95-119 and Tonah (2012) "The Politicisation of a Chieftaincy Conflict: The Case of Dagbon," Northern Ghana, Nordic Journal of African Studies, 21/1: 1-20. 
statutory law which approves of the state compulsory acquisition of this land, making it state land. NGOs' access to capital (grants) and authority from international NGO's ActionAid accords them prestige and power through their access to state authorities and greater legitimacy in policy circles to influence state authorities. Another example is the NGOs that, through media coverage, garner public support for farmers' use of green belts for farming and against the chief who wants to sell the lands to estate developers.

Furthermore, farmers choose between different governance systems which they think support their agenda. An example is a switch from a traditional governance system to the civil society arena and back to the traditional system. A change from one governance system to another or back to the former system is conditioned by the search for a willing listener that might support the interest of the actor. This goes to show that maintaining access to land changes depends on the socio-political situation at the time and also social relations with the people in authority and power (Ribot andPeluso, 2003).

\subsubsection{Land conflict between farmers, chief and a land developer in 2007}

In late 2007 , farmers had an opportunity to challenge the authority of the chief again on Gunbihini old dam, Gumbihini new dam and Waterworks. This opportunity is what Rose (1994) and Lund (1998) call an 'open moment,' which give an actor or group of actors the possibility of reasserting or eroding the power of another actor or institution over resource control. This is done through aligning with other actors or governance systems in order to gain control over resources. This moment began when a developer started constructing a house in the middle of the old dam site. When the farmers saw this, they called a meeting amongst themselves in the field to discuss what to do about the construction going on in their field. They decided to go and meet the lady building the house. They traced her house after talking with the workers working on her construction site.

When they met this woman they explained to her that lands on this site were not meant for residential development because it was a green zone. They pleaded with her not to waste her money and resources developing the plot of land especially as she has no formal legal backing constructing on this site. The lady responded that since the chief had sold the land to her, she would do what she wants with the land as it was now her 'property.' After this discussion with the farmers, the lady intensified her construction activity by transporting a large quantity of molded blocks to the site. The workers worked from morning to night, and the lady paid guards to secure the site at night. When the farmers realised that the lady did not pay heed to their advice and also that, if the building was completed, the law would let the lady have the land and only compensate the farmers, they convened a meeting. During this meeting, they unanimously agreed to demolish the lady's building even though it had reached the window level. Over a hundred farmers from all the Gumbihini sites, organised into associations called 
Gumbihini Daliri (Waterworks), Malitizaa (old dam) and Wun Sonmiti (VRA), were informed on the next plan of action.

At dawn, the next day, in January 2007 the farmers came out and demolished the uncompleted structure on this site (old dam) which they had labeled as illegal. The next day the lady informed the chief of what had happened and called the police to the chief's palace. The chief identified three farmers who were involved in demolishing this building, and they were arrested: Abudu Mahama, Musah Mahama, and Abass Issahaku. The Director of Urbanet was informed of the current situation. He intervened at this stage by going to the District Assembly to speak with the then District Chief Executive (DCE), Mr. Baba. The Director of Urbanet explained to the DCE that he had earlier sent petitions to the assembly and even to Yiendi about the land issues at the Gumbihini site without achieving a lasting solution. Mr. Rashid then explained to the DCE that the farmers demolished an uncompleted building in the Gumbihini old dam site because they thought it was an illegal structure. He agreed that the farmers' violent approach was misguided. However, three farmers had been arrested, and the other farmers were mobilising in the community, saying that if their colleagues are not released by one o'clock, they would march to the chief's palace and burn it down, bringing about chaos in the community.

He also informed the Coordinating Director at the Metropolitan Assembly that if anything happened, he would be prepared to narrate to the nation the events up till this moment including information that he had previously written to the assembly and in response to which he had received no feedback. He pointed out that Urbanet had offered to provide a platform for discussion between the farmers and assembly, but this had never happened, and that the current events were a consequence of that. The DCE, being a politician, did not want the media portraying the assembly as a weak institution not able to handle the lands matters in Gumbihini. He immediately got in touch with the regional police commander and the farmers were released before twelve o'clock, since their colleagues were demonstrating, and he was afraid of what would happen next. After the farmers had been released, the District Chief Executive called a Regional Security Council (REGSEC) meeting, including the then Regional Director of the Town and Country Planning Department, representatives from the Survey Department and Lands Commission, a farmers' representative, and the Gumbihini chief.

The District Chief Executive asked the TCPD to check the planning scheme of Gumbihini and inform the meeting for what purpose this site was zoned. The Director of the TCPD said these areas were considered a disaster zone and a green belt, not meant for development. Also, the Lands Commission was brought to check and confirm the information from the TCPD, which they did. The chief was told that he could not sell the site as it was a green belt, and he consented to this agreement. The farmers and the chiefs were later summoned by the Assembly and the female developer was told she had no right to build in that area as she did 
not have a building permit and the chief has no right to sell plots of land in this area. The farmers were chastised that they had no right to pull down the building without consulting the assembly. The chief still did not relent and kept looking for ways to sell land on farmers' fields, according to rumors circulating in the Gumbihini community.

The next day Mr. Rashid took Metro Television and G Television to the farms. The present chairman, Mr. Karim Salifu, spoke to the press about the conflicts with chiefs on the Gumbihini green belt, relating how the chiefs wanted to sell land used for farming to land developers. He emphasised the importance of vegetable production in the urban area, as a source of food and nutritional security to the population of Tamale and Northern Ghana. This video was broadcasted live on national news to garner public support.

Here we see how Urbanet uses the media as a forum to promote the agenda of farmers to maintain control over their farmlands and also gain legitimacy as a local agent of change. The media is generally used by organisations which state that they are apolitical organisations but politicise issues they consider important for local development which align with their interests. Moreover, the media is used by non-governmental organisations as a technique with which to govern the population from afar, a concept explained in Foucault (2001) and Dean (2010). The idea of governing from afar, as explained in Chapter 2, occurs when organisations, institutions, actors or collective actors use, for example, the media or a strand of law to get people to act in a certain way without them feeling like they are controlled. The media then becomes a tool of power used to control or influence how land is administered on government green belts.

After this incident, Urbanet held discussions with farmers, and they resolved that there was a need to undergo advocacy training to handle their land problems better in the near future. Urbanet wrote an application letter to the Business Sector Advocacy Challenge Fund (BUSAC) on behalf of the Farmers' Union applying for funds for advocacy training. The application was well received; selected executives went for an interview and were told at the end to write a proposal. The union got a consultant, Mr. Alex Bookman, who worked in collaboration with the farmers to get a proposal ready. This proposal was later sent to BUSAC, who validated it and agreed to assist the Farmers' Union in advocacy training. Later in 2011 the Farmers Union registered formally as an umbrella of seven associations, each of which was registered individually (the three associations in Gumbihini mentioned above in addition to the Zagyuri Vegetable Group, Sangani Vegetable Group, Buipela Vegetable roup and the Suglo $\mathrm{N}$-bori Buni Dakpoba. To garner more support for their cause, the farmers came together and created the Northern Region Vegetable Farmers Grower's Union.

In the case above we see that the first step towards maintaining access to land or control over land is through the continual cultivation of the plot of land, as exhibited by the farmers. This is an age-old African tradition of maintaining land by making it productive, that 
is, adding value to land (mise en valeur). Undeveloped government lands are usually considered an easy target by urban vegetable farmers, who squat on these lands with no formal arrangements. In this study area, farmers are squatting on these lands because they know the government can no longer erect buildings there, since these areas are flood prone. Urbanisation and increasing the value of lands has given chiefs an opportunity to take back their lands from government' who do not respect Article 20, Clauses 5 and 6 of the 1992 Constitution, stating that customary lands compulsorily acquired be returned to their original owners if not used for the purpose they were acquired for. Chiefs have decided to take back these lands through land sales to estate developers.

Chiefs have also engaged in forum shopping, choosing the strand of law favourable to their cause to overwrite government hold over lands in these sites. However, the state is cooperating with NGOs and farmers to retain their control over these lands through farmers' occupation, and by so doing have created a hybrid land governance system on these sites. Simultaneously, NGOs are using the concept of 'green cities' to gain legitimacy and authority in securing lands for farmers. Farmers are also using ambiguity created as a result of overlaps in land administration and control between the state and customary land governance systems to gain and maintain their access to their farmland, as already argued in Chapter 6 . The case above suggests that gaining access and control over land for vegetable cultivation is a continual process of negotiation, contestation and conflict resolution by several actors, as explained in Chapter 6. In the coming sub-sections, I will use the notion of the moment of translation from Callon (1986) as a tool to explain how actors negotiate and persuade other actors and institutions with artifacts, ideas, technologies or intermediaries to join their network. The relevant concepts, which will be used to explain how actors convince others to join their networks and help promote their agendas, are as follows;

Enrolment - When actors convince/force other actors to join their network.

Obligatory passage point - A point that an actor must pass through in order to be enrolled in a network.

Intermediaries - Elements that actors use to enroll others into their networks.

Actors - Different human and non-human actors involved in this process of translation.

Network - Constitutes actors enrolled in the network.

Most of the actors' networks will reflect the views or interests of the main actor and not so much that of the other actors. For example, a farmers' network will reflect the views and perspectives of the farmers and not so much other actors like the state and NGOs that form part of the farmers' network.

In maintaining access to and control over public lands in Gumbihini farmers collaborated with NGOs who, through the provision of fences, knowledge on agronomical practices and technology like water pumps, promoted farmers agricultural practice over these sites 
shown in Figure 7.5. NGOs also used the media as a forum to garner public support for urban farming through live television broadcast with farmers who explained the importance of vegetable farming and the land conflicts they encountered with chiefs and to gain legitimacy as providing public services. NGOs further cooperated with the state to legitimise e farmers' use of green belts for vegetable cultivation. Farmers have also negotiated with other actors to maintain use of their farm lands. Apart from collaborating with NGOs, they have also solicited support from senior chiefs, who solved their problem in the short run.

Later they decided to use a strand of formal law, which legalised their use of green belts with the collaboration of the state and NGOs. This happened when the Chief Executive Officer in Tamale with other land agencies showed the planning scheme of Gumbihini to the chief. In this scheme the agricultural zones were demarcated as a green belt not for residential purposes. In this case, the Gumbihini chief has also been enrolled in the farmers' network. We shall see later that actors enrolled can always move out of the network if it does not align with their interest at a later stage. Maintaining access to land depends on one's skills in using forums like the media, symbols like fences, knowledge and strands of law to convince other actors within the socio-political environment involved with the resource under contestation to join their network, as depicted in Figure 7.5. 


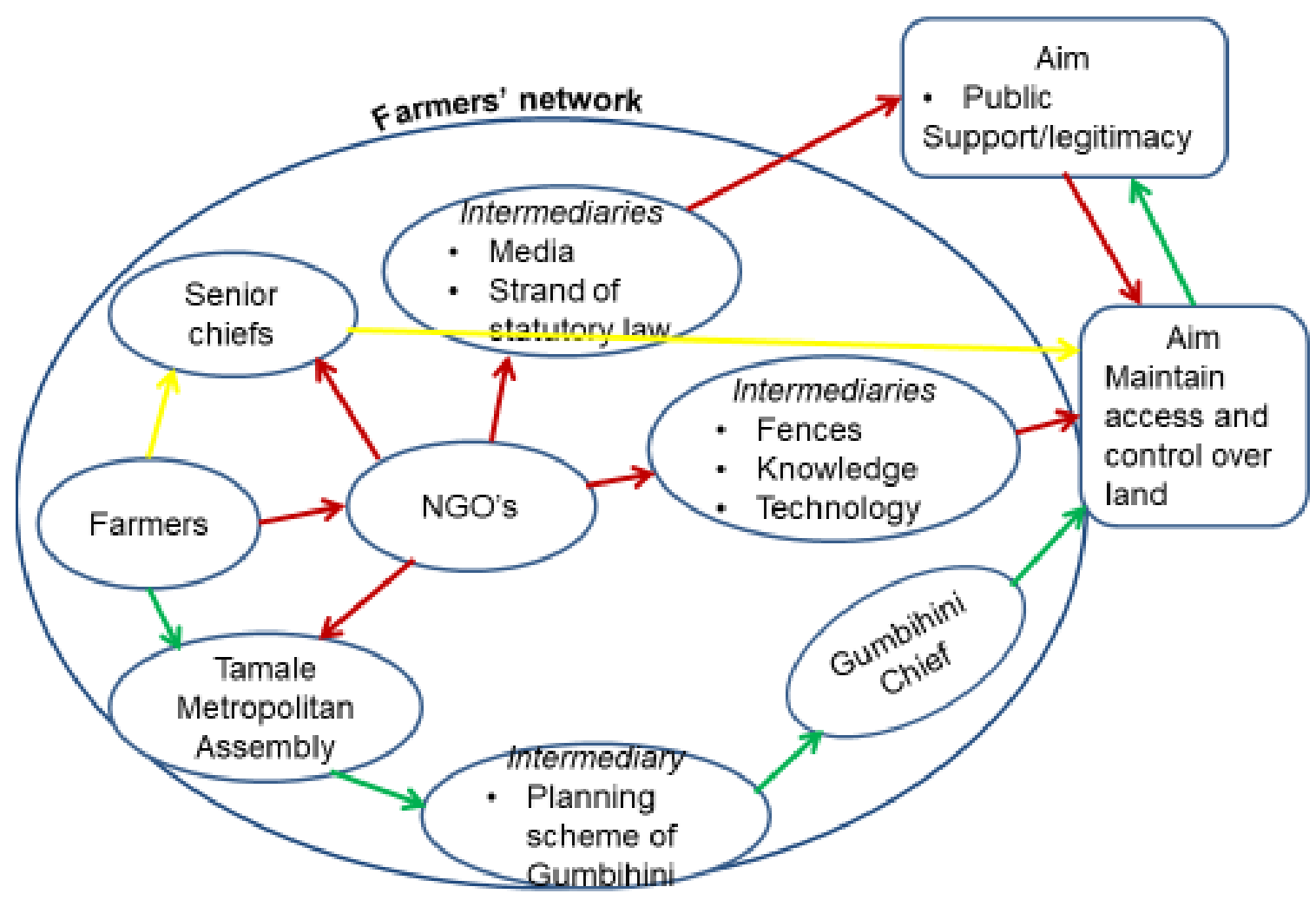

\footnotetext{
$\bigcirc$ Actors and intermediary

Aims of the Actor's network

$\longrightarrow \quad$ Routes of enrollment through the state

$\longrightarrow \quad$ Routes of enrollment through the NGO

Routes of enrollment through the senior chiefs
}

Figure 7.5: An example of the farmers' networks and relationships farmers use to maintain to access land

\section{Source: Author's fieldwork, 2015}

The concept of enrolment by Callon, explained in Chapter 2, is used here as a tool to illustrate how actors are convinced to join networks with the same or similar interests. For example, the state has joined the farmers' network because the presence of the farmers on these lands gives them control over these lands, as green belts according to statutory laws are under state control. This stand by the government excludes chiefs' control over these lands. 


\subsubsection{Maintaining land access through international intervention}

The Gumbihini new dam site was acquired through the power of eminent domain by the state, in this case, the Ghana Water Company (GWC), for the provision of potable water to the people in Tamale. Over the years' chiefs have written several letters to the GWC demanding that this land is returned to them to no avail. Since the reservoir disaster in 1989 this land has been mostly occupied by vegetable farmers, with a few buildings belonging to the GWC. The ownership of this land and interest on it has already been explained above. Farming has been done around the reservoir on this site since the 1940's/50's, with farmlands being passed on to junior relatives as an inheritance from one generation to another.

The new dam site measured about 100 acres before the disaster and flood water covered about 80 acres of these 100 acres. As already mentioned, this flood destroyed the old dam site and its reservoir, as well as property and people. One of my key respondents Mohammed stated that the reservoir disaster might have been as a result of poor maintenance by officers assigned to this task. After the reservoir disaster, 80 more acres of land was available for agricultural activity around the new dam site. This new development led to an invitation from older farmers, which they delivered in the mosque and other meetings, in which they solicited for youths to join them in farming on this site. So new farmers came and started farming while old farmers increased their farm sizes.

In 2011, Mohammed, a farmer on this site who cultivates mainly Hibiscus sabdariffa close to the forest reserve, left his farm in the evening after prayers. Early the next morning on arriving at his farm he saw a boundary marker as shown in Figure 7.3. He informed the chairman of the Vegetable Farmers' Union of the boundary marker found on his farm land. The chairman of the Union called a meeting, and all farmers present unanimously decided that they would wait for the one who placed the boundary marker to come out in the open and then they would fight against this person. Mohammed said after this meeting no chief came out to admit authorising this act. He explained that this act is a strategy sometimes used by the chief to see if farmers would react or keep quiet, as keeping quiet means acceptance of the chief's authority over the resource.

Mohammed said later on that it was disclosed through rumours that the boundary marker was placed by the son of the then Gumbihini chief without his father's consent. Mohammed explained that the new dam area falls under the jurisdiction of two divisional chiefs, the Gulkpegu naa and the Sagnerigu naa, who have divided the land between their junior chiefs, who are the Salamba, Jujuli and Gumbihini chiefs, as shown in Figure 7.4. Mohammed also stated that boundary problems are common between chiefs, as some of them do not know the boundary limits of their areas accurately. This comes as a result of the tradition of the Dagomba people, where when one is enskinned as chief he is showed the land boundaries once, after which it is taboo for him to visit these boundaries. He mentioned that where the 
Gumbihini chief's son placed the pillar was not even on Gumbihini land. There have always been struggles over land use and control between chiefs, government and farmers, but in recent times other actors have also joined in this resource contestation. The new actor I will introduce is a non-governmental organization known as the Italian Autonomous Cooperative from Trento, Italy, which has a sister town relationship with Tamale.

From interviews with a representative of the Italian cooperative, I was informed that the sister town relationship between the province of Trento, Italy, and Tamale, Ghana started with a communication between the embassy of Ghana in Italy and the member of the council delegated to the international solidarity of the autonomous province of Trento around 2010/2011. It was a request from the embassy of Ghana for cooperation and mutual development. This programme was called the 'PROGRAMMA DI COOPERAZIONE DECENTRATA TRENTINO - GHANA UN UNIONE PER LO SVILUPPO RECIPROCO.' The autonomous province of Trento does not deal directly with other governments when carrying out projects but prefers cooperation to take place with municipal council and not directly with the central government. This was decided upon when unaccountable projects carried out in Mozambique and Guinea were used by the Italian opposition party to attack the government in power for unaccountability and lack of transparency in its activities out of Italy. The province of Trento then decided that in carrying out any programme with other countries it will be at the local level, that is, with different municipal councils and not the government. This is because municipalities are considered to have better control over the development of their areas than the central government.

The Italian team made their first visit to Tamale in 2011 to understand what mutual development could be possible with any metropolis in the Northern region. The team consisted of the leader of the cooperative, an agricultural engineer and a technical engineer. The prospective areas selected were Tamale in Northern Ghana and Agona in Southern Ghana. In Tamale, the team spoke with the politicians and the chiefs about the needs of the population. In late 2012, two officers from the Pong Tamale Livestock Center in the Savelugu district North of Tamale, two staff members from the metropolitan agricultural office in Tamale and other officials from Accra were invited to Trento, Italy to have a preview of the type of cooperative system in practice, so discussions could be held and decisions made on what would be of benefit to Tamale and the population.

The first idea of the Tamale delegation was that the cooperative could create a dairy farm and provides a cold van to collect milk, especially during the rainy season when it is abundant. This milk would, later on, be processed into yogurt and cheese for sale. In the long term, the plan was to network with other countries like Burkina Faso to obtain dairy cows, produce dairy products and improve the existing livestock farms in Tamale. Even though there 
was insufficient voltage at Pong Tamale to run processing machines for a dairy farm, the Tamale metropolitan assembly and the Savelugu district assembly were supposed to jointly resolve these problems with plans to start the same project in later years in Tamale. The second option was improving on vegetable production in urban Tamale. The Italian team, made up of Andrea Maschio (leader of the Italian delegation), Claudio Baldessari and Ruggero Andreatta came for a second visit from the $29^{\text {th }}$ of May to the $1^{\text {st }}$ of June 2013 , and the vegetable idea was adopted. The reason for choosing this second option was because there were not enough cows to produce milk all year round for dairy products like cheese or yogurt in Tamale. This choice created a rift between the Ministry of Food and Agriculture (MoFA) in Tamale on the one hand and the farm manager of Pong Tamale and the District Chief Executive of Savulegu on the other hand, who believed that MoFA Tamale had 'hijacked' a project meant for their district.

The next step was the selection of the vegetable production site. A feasibility study was done on reservoir sites in Gumbihini, Fooshegu, Manguli, and Gbelahigu. The Gumbihini new dam was selected, and one of the reasons being the presence of an existing Vegetable Farmers Union, since the Italian team preferred working with an already organised group. The idea was to replicate the cooperative system of Trento with the vegetable farmers belonging to the Union in Tamale. Financial and technical support would come from the cooperative system independent of the government of Italy. The Farmers' Union was invited by MoFA to meet with the Italian team and was embedded into the project. The union members were asked to assist in the measurements of the new dam area, and also in a series of meetings held with the assembly, agricultural officers, and the Italian team. The rehabilitated dam would occupy about 80 acres of land where farmers were already cultivating vegetable and cereals in the dry and rainy seasons respectively. The displaced farmers would be taught to farm fish in the reservoir. This training would be conducted by the fisheries and irrigation unit under the Ministry of Agriculture in Ghana in cooperation with the agricultural engineer from the Italian team.

The Italian agricultural engineer would introduce the cooperative system used in Trento to the farmers in Gumbihini through capacity building workshops. Different cooperative activities would be introduced under a main supervisory body which would be created within the Farmer's Cooperative, as it would be called, rather than a Union. The ideas culminated with a strong operational marketing board where farmers would all combine their products and sell as one through the cooperative body, in order to be able to get a better price and market. Also, storage facilities will be set up, and necessary machines bought depending on the needs of the farmers in the cooperative. The Autonomous Province of Trento envisaged that after this project the Italian government might then become involved in a potable water project in the Fooshegu dam area and Gbelahigu. Reports on the second phase of the project were sent 
to the Metropolitan Assembly on the $16^{\text {th }}$ of January 2014, and they were informed about the visit of the technical engineer to finish up the feasibility studies. In April 2014, details of the contract were being discussed and the reservoir was expected to be reconstructed in the dry season commencing October/November 2014. These plans to rehabilitate the dam resurrected the issue of land ownership in the Gumbihini New Dam area.

When Mr. Paul, an agricultural officer at the Metropolitan Agricultural Unit, went to inform the Gumbihini chief about the new development which would take place on his geographical space the Gumbihini chief was getting a bulldozer ready to pull down some dilapidated structures on this site and prepare it for sale. Mr. Paul immediately contacted the Ghana Water Company (GWC) in Tamale, to find out if they authorised the chief to execute this act. The GWC officials explained that directives had come from the Director at the GWC headquarters in Accra authorising chiefs to build on the eastern side of the site. This new development was reported to the District Chief Executive, who contacted the Director of the GWC in Accra and informed them of the project to rehabilitate the reservoir. He explained the benefits that the rehabilitation of the reservoir would entail and accompanied it with a gentle reminder that the land was public land, meant for state development. With the land ownership issue cleared in favour of the upcoming reservoir rehabilitation, the Tamale Metropolitan Assembly agreed to prepare a bill of quantities, which is a document used in tendering in the construction industry in which materials, parts and labour (and their costs) are itemised. This bill of quantities was later e-mailed to the contact person of the Trento Cooperative Authority. Tamale Metropolitan Assembly was also expected to provide a map of the site of the broken dam, agreeing tentatively that the project should start after the rains in October/November of that year, as mentioned above. The first and second activities were carried out. By October 2015, the third had to be completed and sent to Trento in order for the construction to begin.

In this case study, we see that negotiations over land between the government and the chiefs are not always conflictual, as the GWC authorities had informally agreed to give chiefs some part of the land on this site to sell. Due to varying interests over these lands by different government institutions, the municipal assembly was able to re-negotiate with the GWC by convincing them that rehabilitating a reservoir would serve the whole community. This re-negotiation shows that claims and stakes over land are flexible and change as a result of different socio-political developments and projects in the city. Farmers can maintain access to land not only through their cooperation with government institutions who want to maintain access to public lands, but also through the presence of international development agents who push for urban agriculture at an international level with implications at the local level. Farmers' access to land is maintained through the discourse on the rehabilitation of the reservoir, where fish farming was intended to be introduced, and vegetable farming to continue, 
as illustrated in Figure 7.6 below. Maintaining access to land depends on one's social relationship with actors in authority or state institutions with international links interested in providing social services to the people. Here we see how cordial relationship between state institutions can facilitate farmers' control over land used for farming. The Assembly, for example, renegotiated for lands to use for rehabilitating the reservoir by enrolling the Ghana Water Company into the farmers' network. They did this by convincing the GWC that public lands are meant for public services to serve the community.

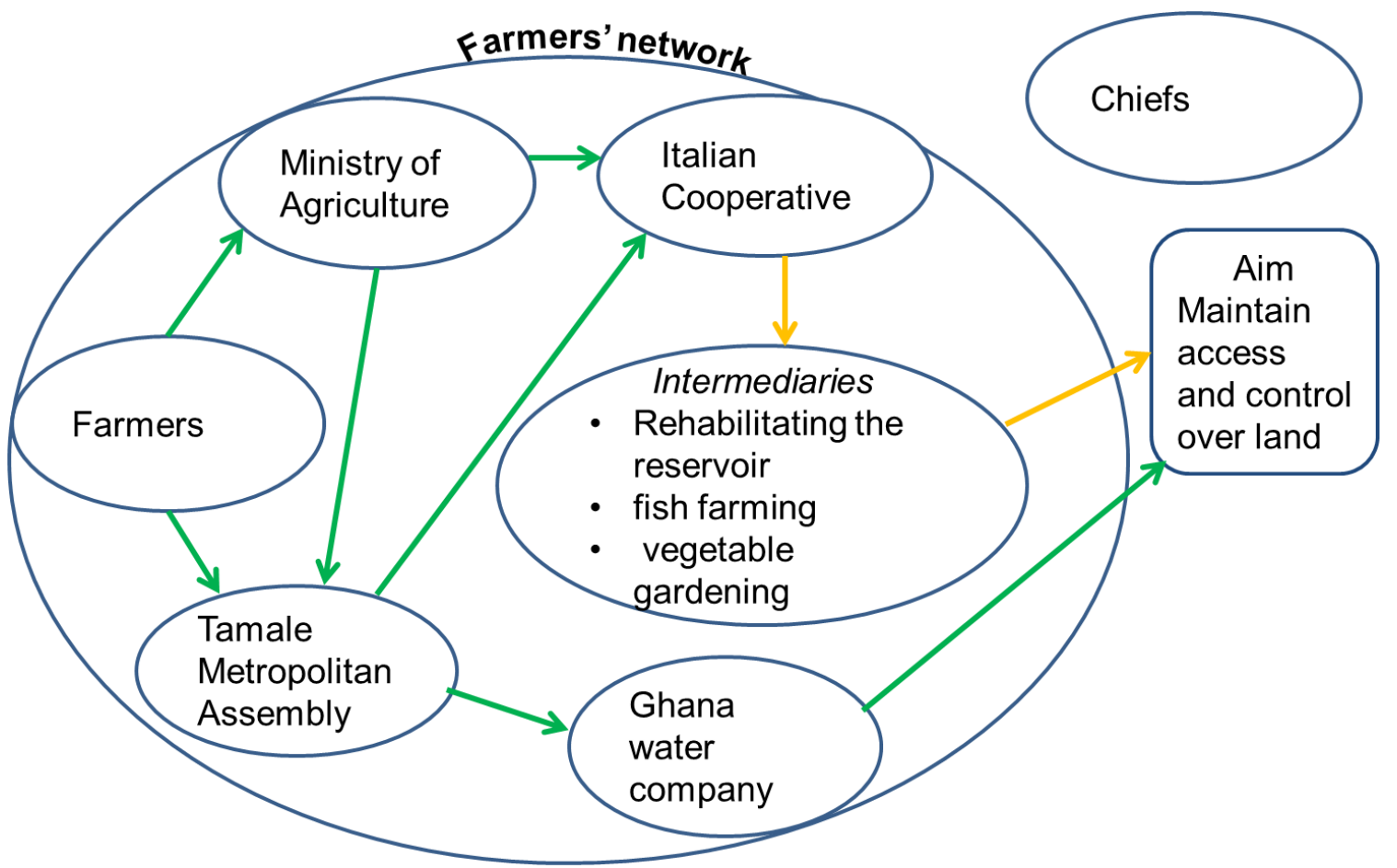

$\longrightarrow$ Routes of enrollment through the state

Routes of enrollment through NGO

Actors and intermediary

Aims of the Actor's network

Figure 7.6: An example of farmers' networks and relationships in maintaining access to land at the new dam site

Source: Author's fieldwork, 2015

Even though the creation of a reservoir will lead to some farmers losing access to their farms, discussions were held on how to renegotiate land claims so that every farmer gets a place to farm. These ideas leave a lot of room for maneuvering and contestation over lands, which may potentially/subsequently create new land owners. An option for non-land owners was also introduced in this new project, in which they would become fish farmers in the reservoir. This option gives farmers access to public water and opens up the possibility of shifting water ownership from a collective to an individual or hybrid ownership system. During a focus 
group discussion with farmers on this site, I registered various conflicting opinions about the idea of a reservoir, especially from the farmers who would lose their land if the reservoir is rehabilitated.

Other farmers were more concerned about a repetition of the 1989 incident, which they believed would be more disastrous than the original flood, considering the rapid urbanisation rate in Tamale. Chiefs have used the 1989 dam incident referred to in this case study as a rallying point for why the reservoir should not be rehabilitated in this area, as the absence of a reservoir leaves spaces within which they can always negotiate for future land sales on this site. Here we see how the different actors are using different discourses to serve their interests on this land. The official papers authorising the new reservoir project had still not been officially signed by 2015 when I left the field site.

\subsubsection{Maintaining access on contested land involving the judiciary}

In 2013, a new Choggu naa was enskinned after the former incumbent died. He insisted on obtaining plots of land to sell in the Gumbihini old dam and Gumbihini waterworks sites. This is possible because the Gumbihini naa is a junior chief to the Choggu chief and according to custom the senior chief can solicit for land to sell from an area occupied by a junior chief if he accepts. The act of giving a plot of land to the Choggu chief to sell benefits the Gumbihini naa, as he will receive a percentage of the proceeds while being spared the stress of dealing directly with the farmers as he has done before, sometimes without success, on these sites. The introduction of this new actor takes the weight of responsibility off the Gumbihini chief, who can now act indirectly under the Choggu naa. A former land buyer who never got a plot of land in Gumbihini old dam in 2007 when farmers demolished the building came forward also to plead her case. She went to the late Gumbihini naa's children to lead her to the current Choggu naa, whom she believed could use his powers as senior chief and allocate her a plot of land in compensation for the land she never got in 2007. The lady referred to here is another land buyer and not the one whose building was demolished by farmers. She understood that if Choggu naa succeeded in getting lands to sell, then she would also succeed in getting a plot to build on.

When she went to see Choggu naa, he called the Northern Region Vegetable Farmers' Union (NRVFU) executives to a meeting at his palace and asked if they could permit the woman to build because 'she has no place to stay.' The executives refused to grant the chief's request. Saleman, one of the executives of the union, narrated how his father bought three plots of land but never built on them because the land was not meant for residential purposes. The Farmers' Union executives asked their secretary to read the letter of Kamkapuya (the regent of dagbon) dating from 2007, which was asking the Gumbihini chief to leave these lands for farmers. This was done because the present Choggu naa was not yet enskinned 
when this letter was written. The Choggu naa stopped the secretary midway and said he does not care what the Kamkapuya's letter says and that as the chief of Choggu so he will do what he wants to do. He then brought the meeting to a close.

During the fasting month of July to August 2013, there was a meeting at Prof. Abukari's elder brother's house with his family brothers, including the Choggu chief and other farmers, concerning the issue of land ownership at the Waterworks site. During the meeting Pr. Abukari said he would not talk much since he was part of the chief's family. He reiterated that this land issue is a family matter, but as the Choggu chief has brought it up, he will talk. He said lands on this site should not be sold and the farmers should continue cultivating the lands. The Choggu chief stated that he would not accept the resolution not to sell lands in the Gumbihini green belt area. His opinion was that since the chief of Gumbihini had no available land left to sell apart from the green belt, he would help him rezone ${ }^{29}$ the green belt area so that it would be used as a residential area. He planned to join forces with the Gumbihini chief to sell lands, particularly on the waterworks site. As the Gumbihini chief owed allegiance to him, he said he would sell the land on this site and give a portion of the proceeds to the Gumbihini naa. The chief told the farmers at the meeting not to worry, that he would partition the Waterworks site and sell only part of it, but the farmers refused, saying if he took part then the next chief coming would also take what is left, and the vegetable farm will eventually become nonexistent.

Nevertheless, the chiefs put boundary markers on the outskirt of the farm lands and sold some plots to an Alhaji, who started building a store on the land, in which he intended to sell building materials. The plot of land where this store was situated shared a boundary with the main road. However, assembly officials came and stopped him. The officials stated that the building was on an area of land earmarked for a future road, so the building was pulled down. Later the chief of Choggu sent surveyors to place boundary markers on the Waterworks site; the farmers decided to take out all the boundary markers after discussing it in their meetings, refuting the authority of the chief on the land. The chief of Choggu called Prof. Abukari, who was also contesting part of these lands with the state. He discussed with him the possibility of giving him an allocation note on all the lands he will demarcate as belonging to his family, so he could prepare what is left to sell to estate developers. Prof. Abukari responded that the land was farmed by his father and great grandfathers, and when the electricity company came to use the land it was just given out to them but not sold. No compensation was taken so when the big reservoir burst and destroyed this area he decided to use the old electrical dilapidated structure to open a computer school, but could not get electricity from the

\footnotetext{
${ }^{29}$ Rezoning is the act of redesigning a land space by changing the activity that was first planned for the area. Rezoning is usually done with the help of a survey officer. For example, land zoned as a green belt can be rezoned as a residential area or a public market.
} 
VRA Company who laid claim to the land. This historical recollection by the head of the Alhassan family was intended to make it clear that his family owned all lands on the Gumbihini Old Dam site and the Gumbihini Waterworks site.

From my interviews with Alhassan, a farmer on the Waterworks site, I understood that the chief of Choggu finally succeeded in persuading Prof. Abukari to let him sell some plots of land at this site. Alhassan recounted that Prof. Abukari had acquired large tracts of land in Vittin with the help of the current Choggu naa when he was the chief of Vittin, before he was elevated to being the chief of Choggu. He also stated that this vast tract of land acquired by Prof. Abukari now houses a school, and because of this previous relationship, Prof. Abukari decided to grant the request of the Choggu chief. The Choggu chief agreed to write an allocation note for Prof. Abukari and sell the rest of the land, which is estimated to bring in more than three billion Ghana Cedi. Due to this new development, the farmers decided to consult the District Chief Executive at his office to complain about the Choggu chief's decision to sell land on the Gumbihini Waterworks site. The reason for this was to inform the authorities of the situation in the field so as not to repeat the 2007 scenario where a building was pulled down. This was also to show that the advocacy training the farmers had undergone was being implemented.

The District Chief Executive consulted the Commander of the Bureau of National Investigations $(\mathrm{BNI})$ who sent a member of staff to investigate the matter. Feedback from the field was that the farmers were fighting the chief over a small plot of land, which is insignificant. Farmers in the focus group discussion I carried stated that they believed the member of staff from the National Investigation Bureau did not ask the farmers what was going on, but probably asked questions at the Choggu palace, and the chief surely told the investigators that he just needed a small portion of land to sell for someone to put up a building. With no feedback from the DCE at the Metropolitan Assembly, the Farmer's Union executives tried meeting the BNI commander through an informal contact with the help of a farmer in Dapokpaa who was farming at the Ganasco reservoir. After this meeting, the BNI commander said he would carry out further investigation, but they got no feedback from him. The farmers on the Waterworks site decided to remove the entire set of boundary markers so that if land buyers came they would not be able to distinguish plots of land for sale. One would-be land developer came to identify his plot of land and the farmers referred him back to the chief, so he went and never came back.

The struggle over maintenance of access to land on this site by farmers, chiefs and the government took a new direction with the introduction of the judiciary through a court case involving the Reverend Lawyer Luguterah, which spanned from 2007 to 2015. In analysing this case, I will use the notion of the moment of translation from Callon (1986). This will work as a tool to explain how chiefs gain access to public lands and sell them to land developers, 
and how farmers negotiate with chiefs, government and non-governmental organisations to gain and maintain access to land. Figure 7.7 restates the actors involved in this land struggle and the intermediaries used by the different actors to access and maintain control over different resources. Intermediaries, as shown in the table below, are ideas, technologies and even artifacts used by an actor to convince another to join his/her network.

Table 7.2: Summary of different actors and the intermediaries they used to access and maintain control over resources

\begin{tabular}{|c|c|}
\hline Actors & $\begin{array}{l}\text {-Farmers } \\
\text {-Reverend } \\
\text {-Prof. Abukari } \\
\text {-Ministry of Agriculture } \\
\text {-Tamale Metropolitan Assembly } \\
\text {-Gumbihini chief } \\
\text {-Choggu chief } \\
\text {-Non-Governmental Organisation } \\
\text {-Italian Cooperative } \\
\text {-Ghana Water Company }\end{array}$ \\
\hline Intermediaries & $\begin{array}{l}\text {-Media } \\
\text {-Strand of statutory law } \\
\text {-Fences } \\
\text {-Knowledge } \\
\text {-Technology } \\
\text {-Planning scheme for Gumbihini } \\
\text {-Rehabilitating the reservoir } \\
\text {-Fish farming } \\
\text {-Vegetable gardening } \\
\text {-Fake letter from the electricity company } \\
\text {-Pay for a plot of land } \\
\text {-Court judgement (land will be auctioned) } \\
\text {-Receipts for payment of land } \\
\text {-Reliefs } \\
\text {-Notice of Judgement (Land has an owner) }\end{array}$ \\
\hline
\end{tabular}

Source: Author's fieldwork, 2014/15 


\subsubsection{Court case between the chief of Gumbihini and Reverend/lawyer Luguterah}

In 2007 a case was brought before the Judge of the Tamale High Court on a land transaction between Reverend Luguterah and Chief Fuseini Nabila with Sayibu Fuseini of Gumbihini. Reverend Luguterah, also a lawyer by profession, stated through his legal counsel in court that he was searching for a parcel of land to buy in Tamale for the construction of his church in 2007. He was introduced by a land agent to Chief Nabila of Gumbihini, who asked Sayibu Fuseini to show him a parcel of land available for sale. He was shown the land from a distance, and he was told it measured 4.4 acres, close to an abandoned engine room and a dilapidated storey building. Upon inquiry on the said plot of land from the chief, he was informed that this land was once the property of the Volta River Authority (VRA) Electricity Company but has been reverted to the Gumbihini skin.

Reverend Luguterah said he was convinced by the intermediaries or technology the chief showed him to enter his network. One of the intermediaries was a letter, supposedly from the VRA authorities, dated $5^{\text {th }}$ June 2007. Part of the letter stated that the land and structures had been handed over to the Gumbihini skin. He was further presented with a site plan for the said plot of land, as depicted in Figure 7.8. All these documents, which I shall refer to as intermediaries, are technologies used by the chief to convince Mr. Luguterah (who in this case study is interchangeably referred to as the buyer, reverend, and lawyer) to become enrolled in his network. This was possible because Luguterah believed Chief Nabila was the obligatory passage point through which he could move to gain access to the land he needed to construct a church for his congregation. 


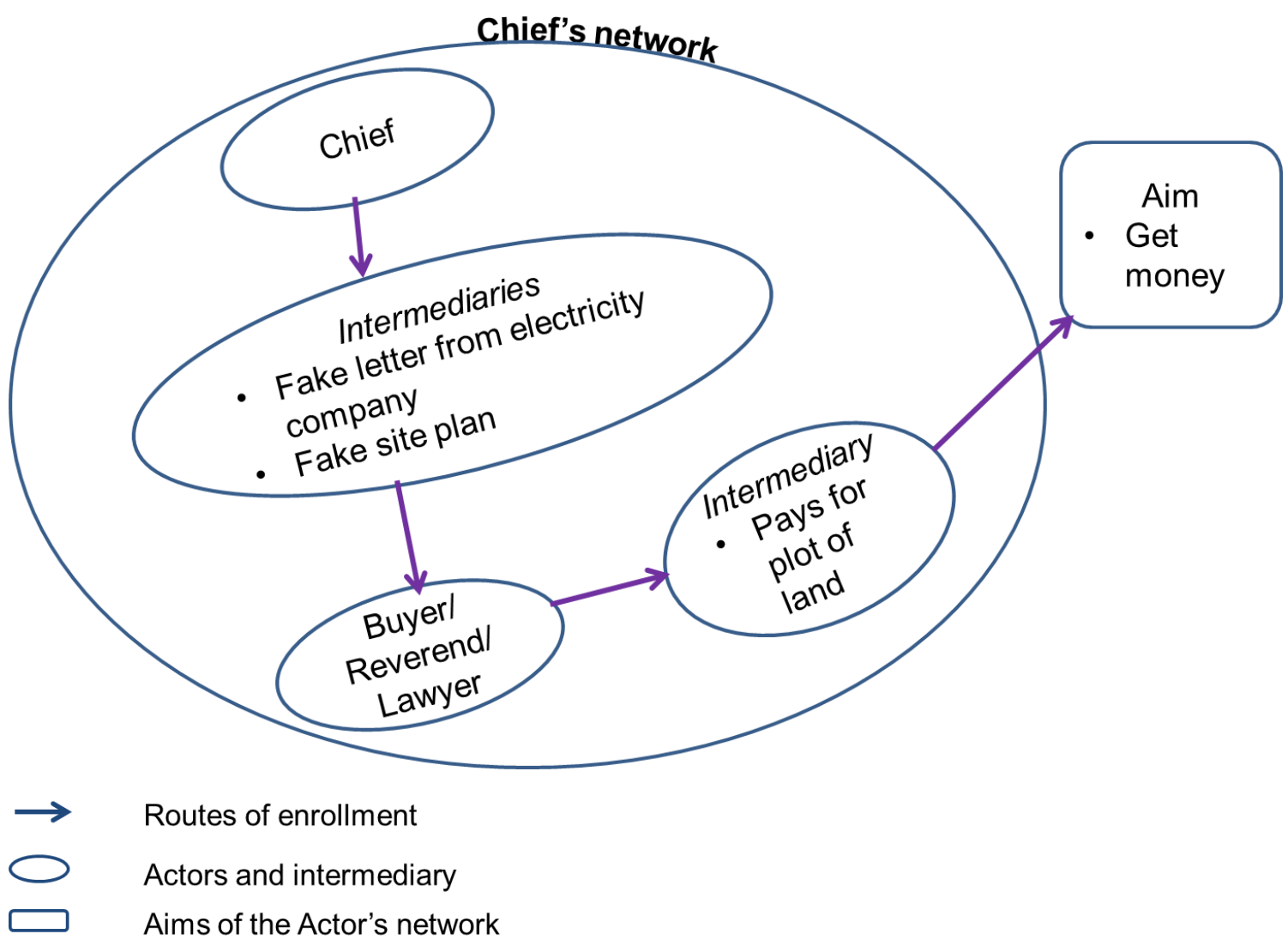

Figure 7.7: Chief's network to sell land

\section{Source: Author's fieldwork, 2014/15}

The price of the plot of land was settled at 60,000 Ghana Cedi on the $23^{\text {rd }}$ of August 2007; 20,000 Ghana cedi were paid in advance, and a receipt was issued. Luguterah was told that he could start building after the final payment was made. He made the final payments but realised too late that he had been deceived by the chief when he was informed that he could not get a lease for the land by the Lands Commission. The reverend, as shown in Figure 7.8, then tried to get back his money or obtain another piece of land from the chief Nabila through the judiciary system. He channeled his complaints through his legal counsel. He presented the fake letter from the chief, the receipts for the land and the fake site plan as evidence to support his case against the chief of Gumbihini. He pleaded in court that his congregation at the youth center in Tamale was growing and already needed a new and bigger space for Sunday service, and he could not do anything about it as he did not have any more money available to acquire another plot after losing out on his deal with Chief Nabila.

He pleaded with the court to grant him monetary rewards for the plot of land he paid for and also to get Chief Nabila pay for damages. He was granted reliefs 1 and $2^{30}$ in the form

${ }^{30}$ Reliefs are all types of benefits which an order or judgment of court can give a party to a lawsuit, including monetary awards, injunctions, returns of property, property titles, alimony etc. 
of monetary rewards on the $22^{\text {nd }}$ of November 2007, amounting to a compensation of 5000 Ghana Cedi. The judge, his Lordship Justice Kwame Ansu-Gyeabour, ordered the Gumbihini Chief (Nabila) to be served a notice of assessment and hearing notices to appear in court on the $7^{\text {th }}$ December 2010, but chief Nabila and Sayibu failed to do so. The judge, therefore, ordered the reverend to open his case. In the writ of summons on the final judgment, the reverend was granted all four reliefs filed on the $6^{\text {th }}$ of August 2010 and awarded an additional 2000 Ghana Cedi to add to the 5000 Ghana Cedi of $22^{\text {nd }}$ of November 2007. The chief, however, was still not enrolled in Luguterah's network as he neither appeared in court nor tried in any way to get another land for Luguterah or reimburse his money. He did not also bother about the monetary rewards he had to pay Luguterah according to the court's judgement.

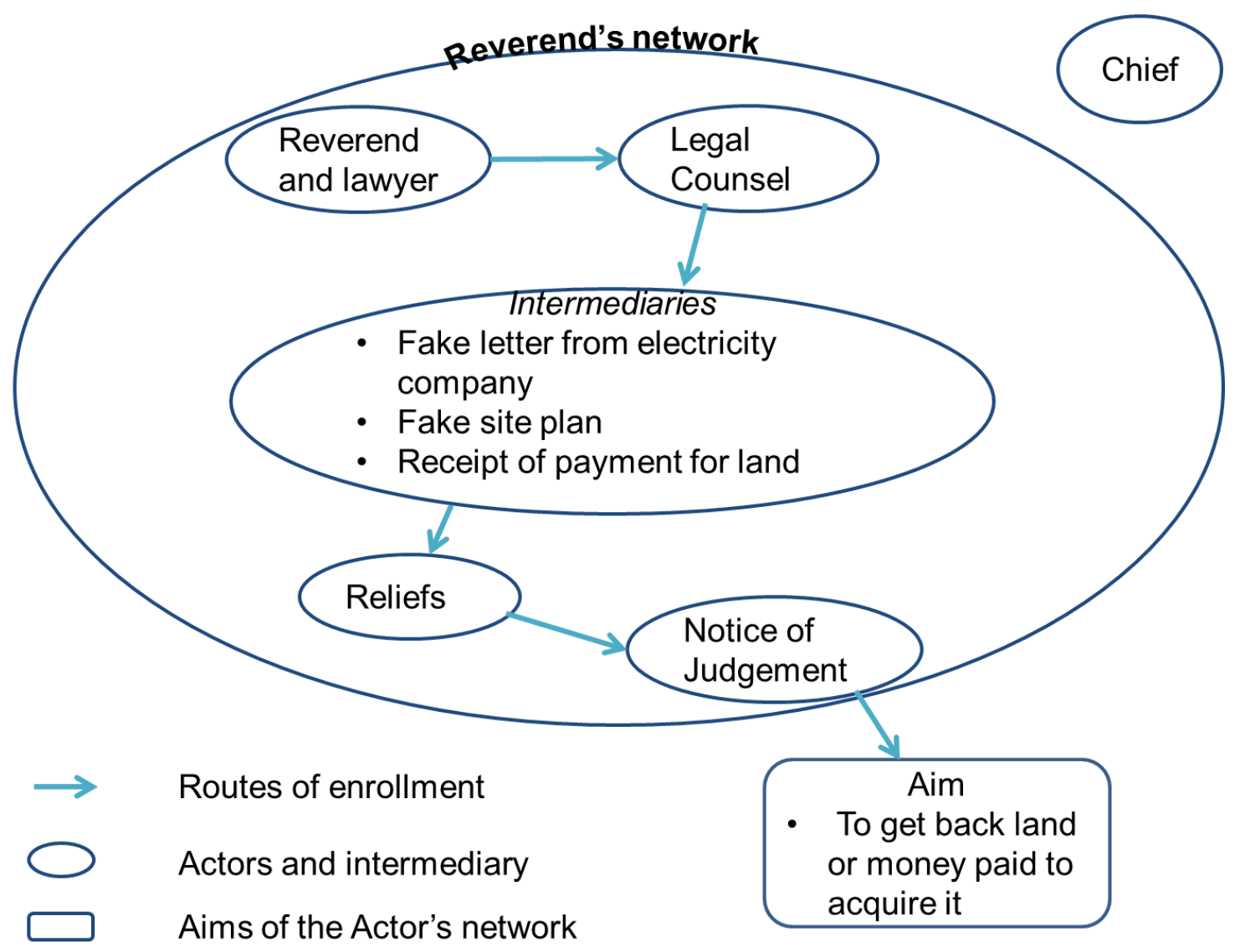

Figure 7.8: Reverend's network to get back the plot of land he bought or monetary rewards

\section{Source: Author's fieldwork 2014/15}

When Reverend Luguterah heard that the plot allocated to him, known as Plot A Blk 3 Ward A, had been placed on the market, a common occurrence as chiefs sometimes sell the same plot of land to multiple persons, Luguterah attached a copy of his judgment on a notice board and placed it in the middle of the field in 2013, as shown in Figure 7.9. This sign by the 
lawyer has driven prospective buyers from this site, according to information revealed through interviews with farmers on this site.

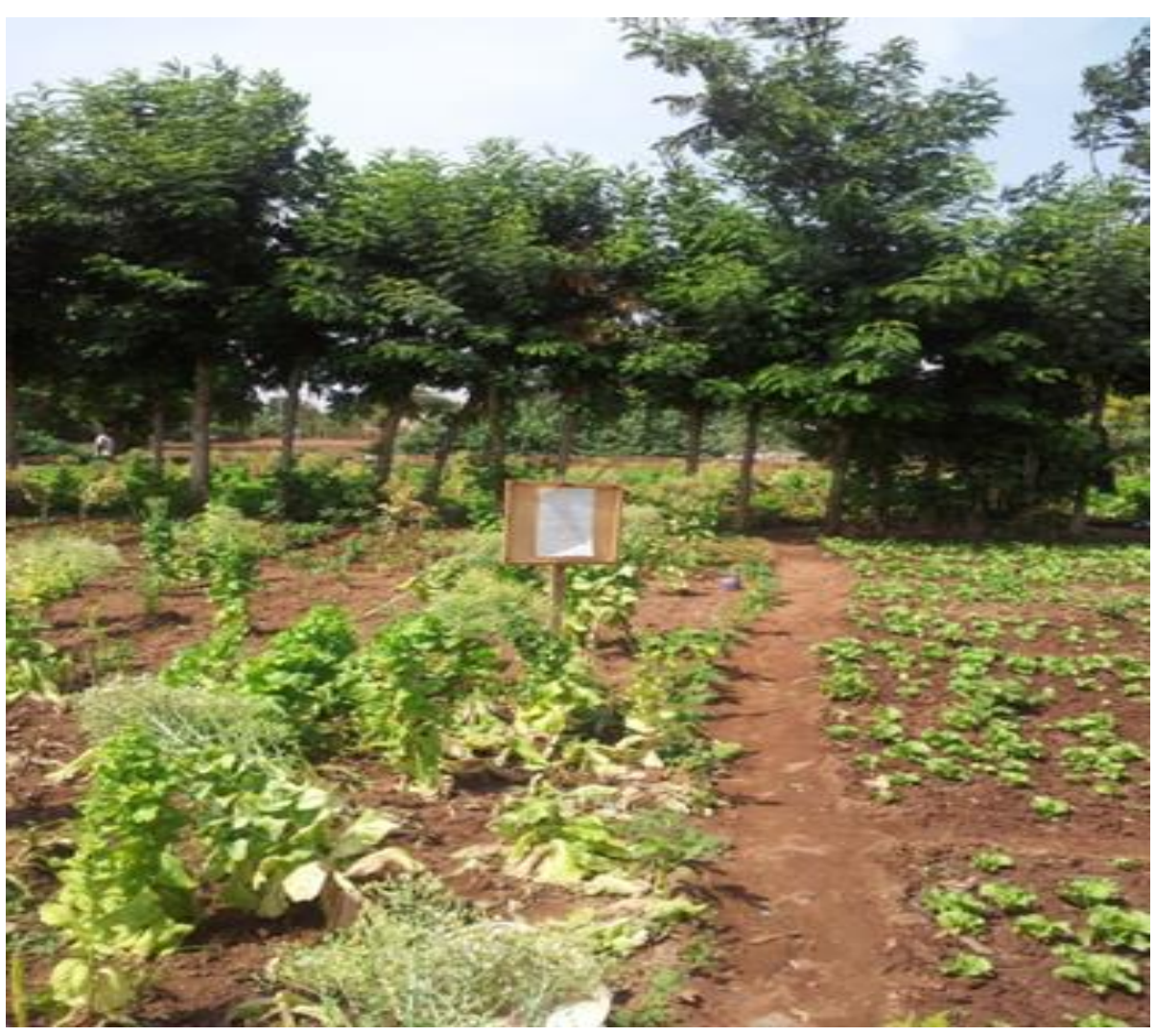

Figure 7.9: A judgment sign post indicating this land has been sold Source: Author's fieldwork, 2015

Alhassan, a farmer at Gumbihini waterworks, said he heard from informal talk in the community that Luguterah realised he had been duped by the chief only after he had a discussion with Prof. Abukari, and later confirmed at the Town and Country Planning Department, that land on this site is not for residential purposes. He also said that no one was quite sure whether Reverend Luguterah knew this land was not for residential purposes but just wanted to take advantage of the politics of rezoning lands by the chiefs. This is a situation where lands zoned as green belts, for markets or toilets are rezoned as residential areas by private surveyors paid by the chiefs. Even though this activity is illegal, it occurs with no penalty. Prof. Abukari in 2013 had also put up a notice close to the Gumbihini Waterworks fields to discourage buyers from purchasing land on this site, as shown in Figure 7.10. 


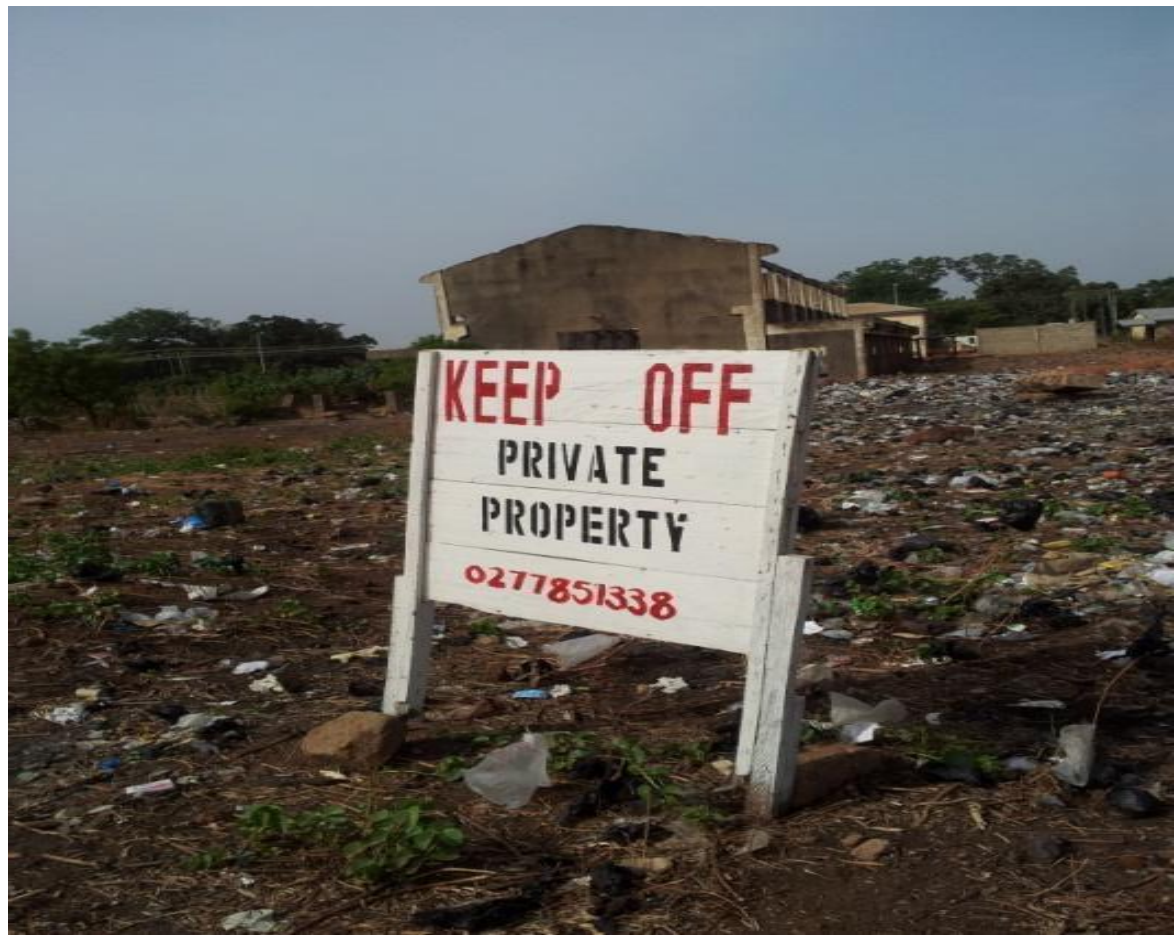

Figure 7.10: Signpost at the Waterworks site

Source: Author's fieldwork, 2014/15

According to more in-depth interviews with Alhassan and the high court registrar, I was informed that the court had passed an order that Plot A Blk 3 Ward A should be auctioned and the money should be given back to Luguterah, as shown in Figure 7.11. When a new Choggu chief was enskinned, he brought up the Luguterah case as a way through which he could sell land in Gumbihini in collaboration with the newly enskinned Gumbihini chief. This was after his first plan to sell land belonging to the Tamale Polytechnic failed amidst strikes from the students. The Choggu chief said he was interested in allocating lands at the Gumbihini waterworks site to estate developers in order to amass funds to pay back Luguterah's money taken by the former Gumbihini skin. With the Choggu chief in the scheme of events, on the $6^{\text {th }}$ of September 2014, the counsel of the Gumbihini skin asked for an out of court negotiation with Luguterah, requesting that the court judgment be halted, but his demand was thrown out of court. When I asked the high court registrar why this out of court settlement was denied, I was informed me that the courts had already decided to auction this land to the public and reimburse Luguterah's money after getting no response or appearance from the former Gumbihini Skin during the court processes.

This situation acts as an instance where we see how different state agencies disagree on land issues and these disagreements, through statements or actions, change resource access and recreate new property rights. These contestations over land use and management influence how the various actors implicated gain and maintain their control over these lands. 
When Prof. Abukari heard the court's decision to sell these lands to pay back Luguterah, he suggested that he pay off the chief's debt to Luguterah, so, according to tradition, all the lands on this site would now belong to his family, and he would let the vegetable farmers continue farming. The newly enskinned Gumbihini chief refused this suggestion because accepting would mean forfeiting land traditionally under his control. The chief was also keen that the interest on this land would not change to private ownership, where access is closed, and would remain public, so access could always be contested. He preferred the land contestation to stay between the skin and the government and not a private owner, like Prof. Abukari, who is political and traditional elite. The present Gumbihini chief then decided to pay back Luguterah for the land sold to him in 2007.

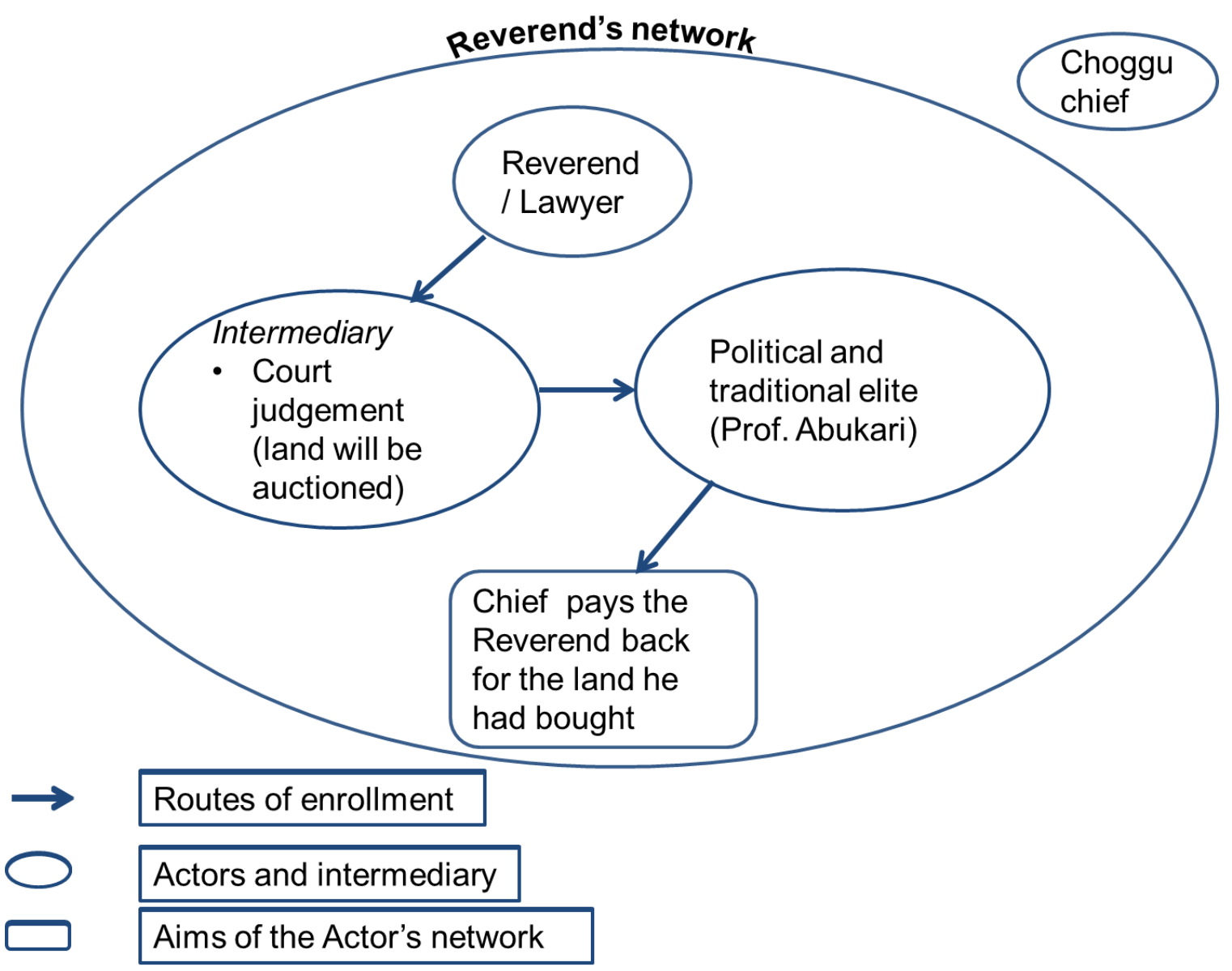

Figure 7.11: Luguterah's network to get back his money/Land from the chief Source: Author's fieldwork 2014/15

From this extended case study, we see that different socio-political institutions are implicated in controlling and maintaining access to land. Also, the traditional institution is embedded in the socio-political structure of the society and is accorded more legitimacy from the 
public than the legal system in this case study. For example, even though the judiciary system was brought in, the chief was not enrolled in this network, as he refused to pay back Reverend Luguterah or give him another land. Immediately Prof. Abukari came into play, the chief decided to pay back Reverend Luguterah so that he could always seek ways to reallocate these lands later. In this case study, farmers seek solutions from different institutions at different times which they believe can solve their land problems. They first sought help from the chieftaincy institutions in the form of senior chiefs and moved to the government and Non-Governmental Organisations when their interest was not supported by the chieftaincy institution. Politics, political affiliations and chieftaincy are a potent mix in Ghanaian society, which is why the intervention of a prominent political and traditional figure like Prof. Abukari convinced the chief to pay back Luguterah for the plot of land he paid for but could not occupy. The processes of maintaining control over land work through building networks of interests and convincing/persuading other actors, institutions, and organisations through discourses and intermediaries to be enrolled in a network. These processes are complex and fluid as illustrated in this chapter in the different Figures.

Technologies, or what I refer to as intermediaries, such as boundary markers, receipts, letters and sign posts are all used to construct meanings by different actors to suit their interests, as shown in Figures 7.5 to 7.11. Ambiguity and overlaps between government agencies and sometimes between government and traditional authorities, have given farmers openings within which they can stake claims to resources such as land, water, and seed. Hybrid systems of land governance have also resulted from farmers' collaborations with the state and NonGovernmental Organisations, resisting traditional governance in their struggle to maintain access to land. Simultaneously, farmers and Non-Governmental Organisations have also gained legitimacy from the public and other politico-legal institutions for their different activities.

\subsubsection{Maintaining control over communal and undeveloped private land}

I explained in sections 6.1.1, 6.1.2 and 6.1.3 how farmers gain access to farmland on communal and undeveloped private lands. In this section, I will explain how farmers maintain control over these different land types. Maintaining access to these different land types entails creating and maintaining a good relationship with the original land owners. Maintaining a healthy relationship entails giving the private landowner or chief salt, money and sometimes part of the harvest as a sign of good will. In some other cases acting as a barrier to land encroachers is enough, especially for absentee private landowners who are living abroad.

One can also maintain access to communal lands through integrating the community into a proposed farming concept and providing the necessary technology for implementing this new farming idea. An example is the dry season vegetable farming idea introduced in 
Sahapelegu by an experienced farmer from the Gumbihini old dam site, as explained in section 6.1.3. I refer to this experienced farmer as a 'supervisory/expert farmer' because he had gained technical knowledge from his experience and association with Non-Governmental Organisations and research institutions, which he is using to train other farmers on this site. Apart from negotiating with the chief to gain access to land and water at the Sahapelegu site, he arranged to get technological inputs like water pumps, and also to bring market opportunities to convince the chief and local farmers to take part in the agricultural activity. Technological adoption might not guarantee one's control over land when a chief is included in an agricultural activity, as argued in Chapter 5, but there is more security in the continual use of these lands, as the chief is the allodial owner and only he can take away communal land or allocate it to another.

Here we see clearly that land access is maintained through giving gifts to the land owners. Services are also exchanged whereby farmers assist landowners in fighting land encroachment and as a result they are allowed continual access to these lands. This example is a continuation of section 6.1.1 to 6.1.3 on how communal or private land is maintained. The details here reinforce the argument made in the previous chapter and present how lands, once accessed, can be retained. Here the idea of social relations as a way of accessing and maintaining lands is reinforced.

\subsubsection{Maintain access to land in irrigation sites}

There are two main irrigation sites in the Tamale metropolis, the Golinga and Bontanga Irrigation sites. Accessing lands on the Bontanga irrigation site has been explained in Chapter 6 . Lands on irrigation sites are generally accessed through a formal process, where lands are usually given out to original owners of the lands where the reservoir and catchment area existed, and then to other interested farmers from the surrounding communities. There are formal rules laid down on how land should be accessed on irrigation sites, but these rules differ depending on the irrigation site. Most of these formal rules have been laid aside, as other informal rules have emerged to take their place. As already explained in Chapter 6, land access is shifting away from government control into a capitalist market system, where farmers on these sites are renting out their plots of land especially during the dry season to migrant and outside farmers for vegetable cultivation.

Access to land is now based on financial capabilities of prospective farmers and no longer through registration on the irrigation scheme waiting list. Maintenance of soil fertility is also an essential element which determines whether a farmer renting land on these sites can get continual access to the plot of land needed for his agricultural activity. This is corroborated by the results of a study conducted by Avornyo et al. (2014) which states that physical and 
chemical properties of soils at the Golinga irrigation, for example, have been negatively affected by continued intensive agricultural practices. This means that maintaining access to land in an irrigation site in the dry season warrants a good soil fertility practice by the lessee.

Presently in the Bontanga irrigation site, most farmers maintain access to their plots of land by training junior relatives to take over from them when they retire.

The plots of land are no longer handed back to the irrigation officials when the farmer is old, as formal irrigation rules dictate. Lands are now passed on to other family members as an inheritance (Nchanji et al., 2016). Farmers have chosen to adhere to the traditional usufruct land law, which opens a route through which they can maintain access to these lands and in this way, promote family farming, which is disappearing with the communal land system, as chiefs are re-allocating these lands to estate developers. Due to the mixed management of irrigation sites by farmers and government officials, a hybrid system of governance has emerged, and farmers are taking advantage of this opportunity to create informal rules which permit them to maintain control over their lands.

There also exists a unique case regarding women's land access and control in irrigation sites, introduced by international Non-Governmental Organisations like United States Agency for International Development (USAID). This is unique because women get access and control directly over lands in irrigation sites in contrast with customary access where land is not only accessed through a male member in the community but also is controlled by them and not the women (Nchanji and Bellwood-Howard, 2016a). Generally, rights to plots of land are allocated to farmers in irrigation sites, and from interviews with them, I was told that technically they believe they have the right to decide on how to manage their lands. To maintain access over these lands, farmers are also expected not only to farm on the land continually but also to pay their water dues.

In this section, a co-construction of government and farmers' rules has led to new land rules and laws, with informal rules gaining legitimacy from the public. Even though good social relations and relationships are necessary for accessing and maintaining resources as a whole, financial capital has an additional role to play, especially for migrants and non-indigenes. In addition, access and maintenance over land are being reconstructed in irrigation sites, as women now have rights over land and do not rely on a male counterpart to maintain access to the land as tradition demands on communal lands. As a result of pressures from the international agricultural community, gender sensitive agriculture has been integrated into irrigation policies in Ghana, as indicated by the Ministry of Food and Agriculture (2011). 


\subsection{Maintaining access to water}

As already discussed in Chapter 6, Tamale gets most of its water used for domestic and agriculture activities from reservoirs, dugouts, wells, ditches and streams. There are different interests or rights attached to these water sources, and these rights vary from one community to the other. The provision of domestic water for the city is the sole responsibility of the Ghana Water Company (GWC). Water for peri-urban and rural areas is provided by the Community Water and Sanitation Agency. These agencies are expected to manage and supervise the provision and use of water for domestic use to the different target populations. In this section, I will use examples from Table 6.1 to explain how farmers maintain control over these different water sources they have accessed for dry season farming.

\subsubsection{Maintaining access to water through technology}

Vegetable gardening relies mainly on water from dugouts and reservoirs, especially in periurban areas. In Fooshegu, like other peri-urban communities, water from the reservoir is used mainly for domestic activities like washing clothes, cooking and drinking. It is also used for agricultural purposes, such as dry season vegetable cultivation, and as a drinking source by small ruminants and cattle. These competing water users manage this resource quite well except in the late dry season when the reservoir starts drying out, as shown in Figure 7.12.

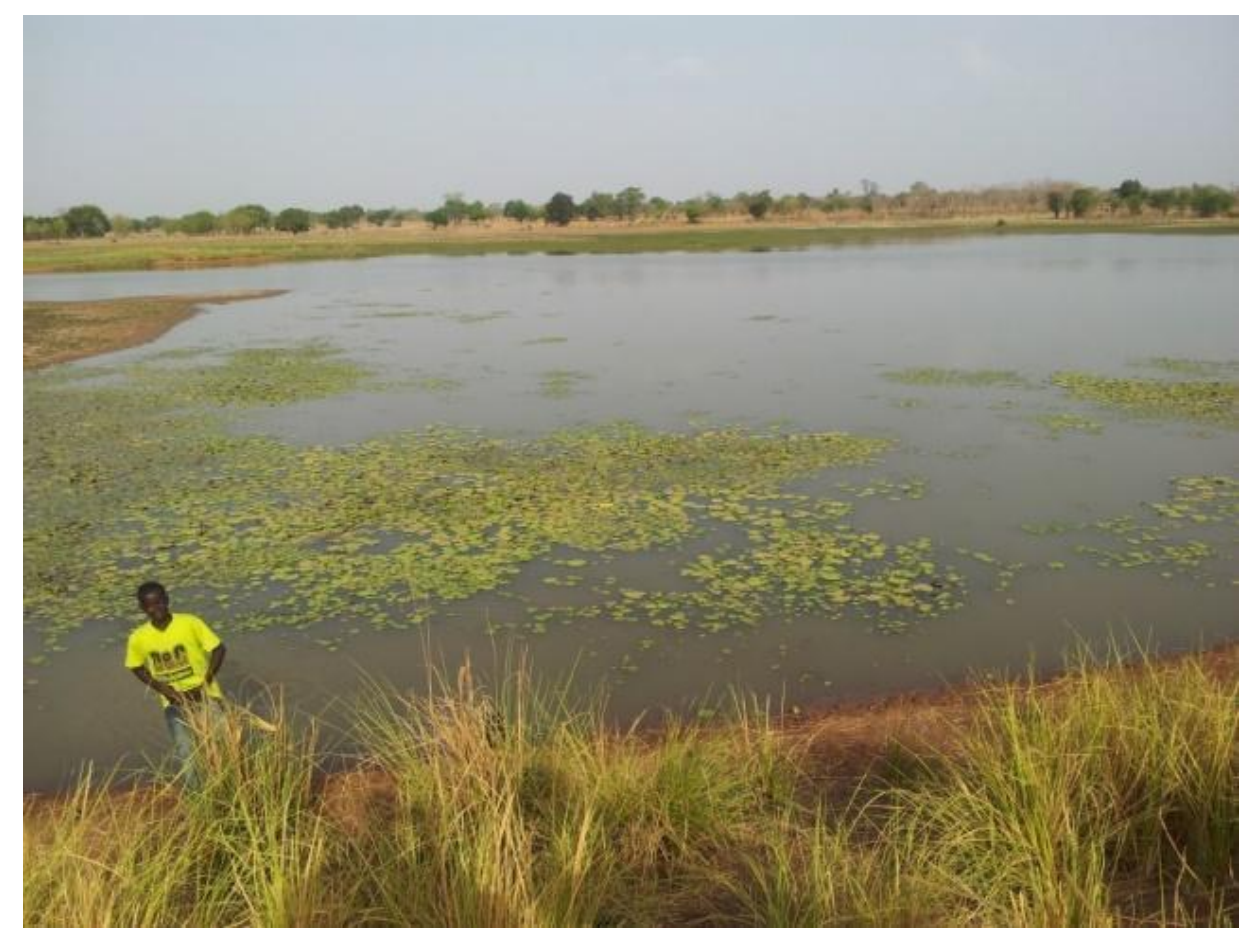

Figure 7.12: Fooshegu reservoir in the height of the dry season

Source: Author's fieldwork, 2014 
Information gotten from a focus group discussion with vegetable farmers in Fooshegu reveals that when water starts drying up, the community usually pressures the agricultural users to stop their activity. The reason given is that everyone uses water from the reservoir for domestic purposes, but not everyone farms in the dry season. So, since water benefits all in the community, agricultural users have to stop their activity or look for other alternatives to continue practicing dry season farming.

Dry season vegetable farmers, in maintaining their access to and use of water from the reservoir in Fooshegu, have joined forces with non-governmental organisations like New Energy, who have provided them with solar water irrigation facilities and equipment for drip irrigation. These technologies are meant to reduce labour and ration the quantity of water used for irrigation, especially in the dry months. According to officials from New Energy, these technologies promote sustainable water management practices and reduce water competition and conflicts between different water users in the dry season. In addition, a pilot study is being carried out on how to grow vegetables in a greenhouse using drip irrigation, as shown in Figure 7.13. The community development officer at New Energy also said farmers had been integrated into this exercise, and if successful it will be upscaled later.

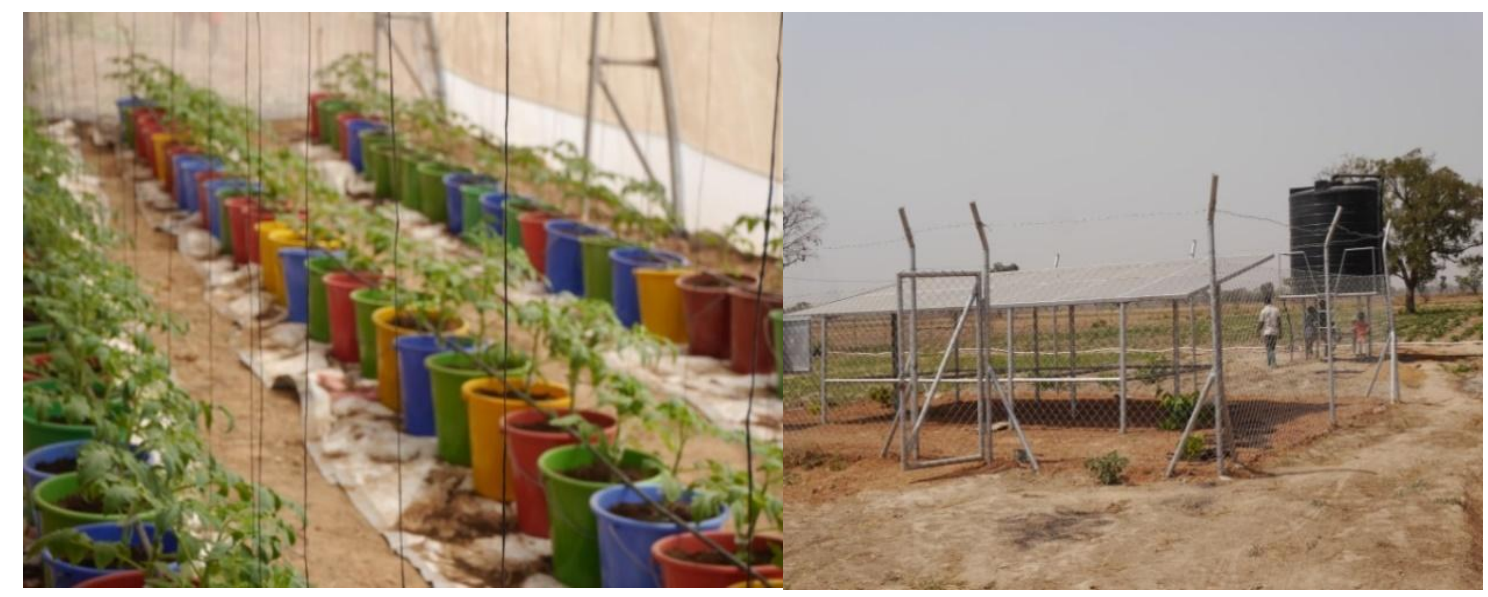

Figure 7.13: A greenhouse and water solar plant in Fooshegu

Source: Author's fieldwork, 2014

It is important to mention here that, as a result of competing use of water at Fooshegu, some farmers had already left in search of other lands to grow their vegetables and some had moved to Datoiyili. This was as a result of easy access to land from the chief of Datoiyili and a constant water supply from a stream that flows from the Golinga irrigation. In Datoiyili, farmers have less competition for water due to the presence of a stream which does not dry off and a dugout which is used by the surrounding communities for domestic purposes. The main competitors of dry season vegetable farmers on this site are cattle and small ruminants that 
are brought over during the dry season by Fulani for pasture and water, as shown in Figure 7.14 .

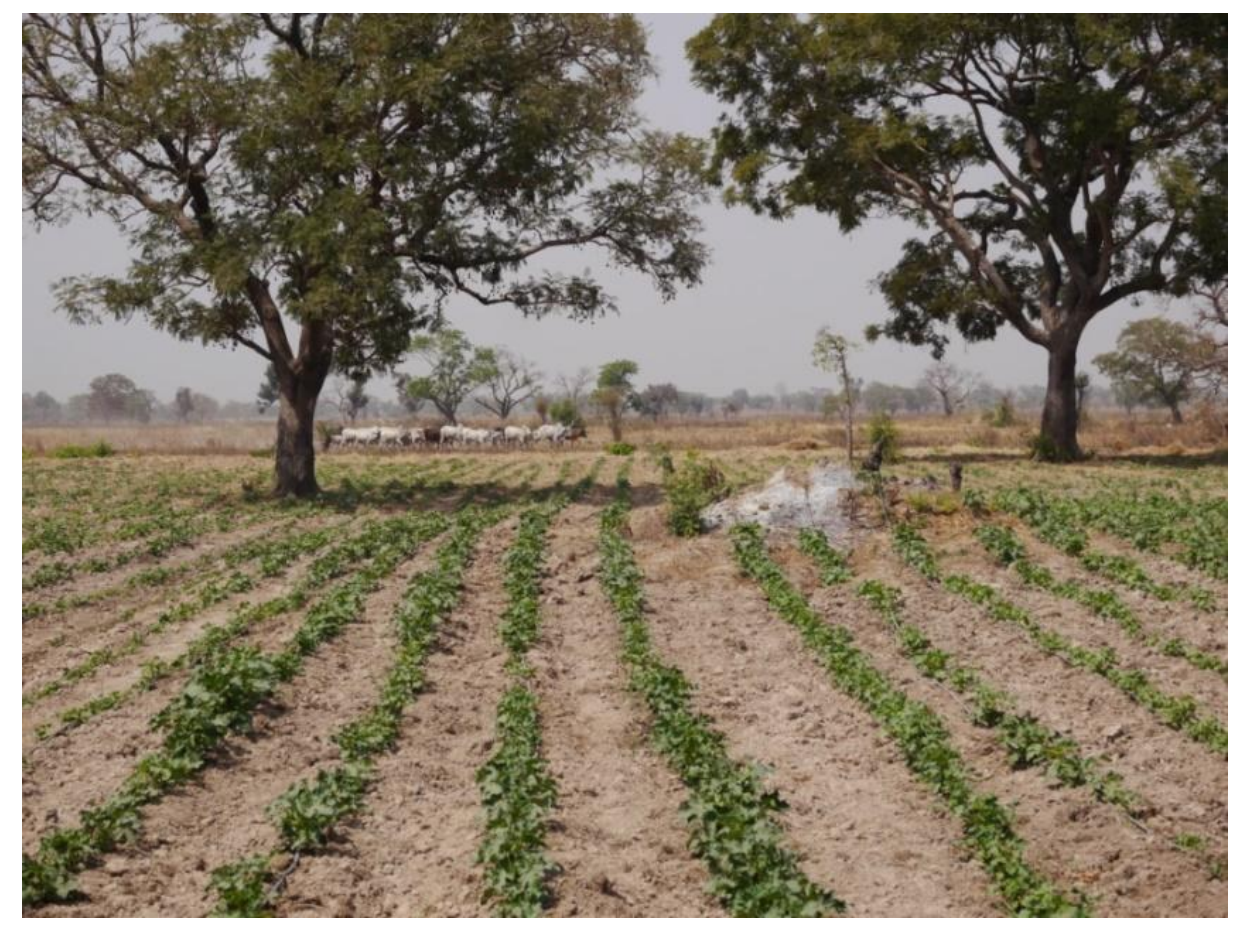

Figure 7.14: Drip irrigation site in Datoiyili with cattle herd close by Source: Author's fieldwork, 2014

In the section above, access to water is maintained through farmers' cooperation and negotiation with other actors like New Energy. As already discussed in Chapters 2 and 6, NonGovernmental Organisations like New Energy come in as local development agents with the will to improve farmers' agronomical know-how or to assist them in maintaining access to resources, as argued in Li, (2007a). Technologies here have become a tool used to convince and enrol farmers into the networks of NGOs so as to carry out projects financed by international NGOs whose global agenda have implications for the development policy of the country. Here the idea of transnational governmentality comes in as global policies are made relevant at the local level. An example is the inclusion of gender sensitive agriculture into the national irrigation policy in Ghana and the practical implementation at different irrigation sites as discussed in chapter 6.

\subsubsection{Maintaining water access in irrigation sites}

Irrigation sites are created for agricultural activities and, as such, water supply is constant, as seen in Figure 7:15. Once one gets access to a plot of land at an irrigation site, water is an 
additional bonus, but one that attracts a fee. This fee is usually used for general maintenance of water pipes and pumps, which carry water to all plots of lands on this site. Maintaining water access in irrigation sites in Tamale like Golinga and Bontanga requires a joint collaboration between the farmers-based organisations formed at the irrigation site and the irrigation officers. This collaboration between the farmers and the government, as explained in the previous chapter, came as a result of a redundancy exercise by the Government Irrigation Development Authority (GIDA). This led to a hybrid irrigation governance system in which farmers were trained to work with irrigation officers in order for these reservoirs to remain functional.

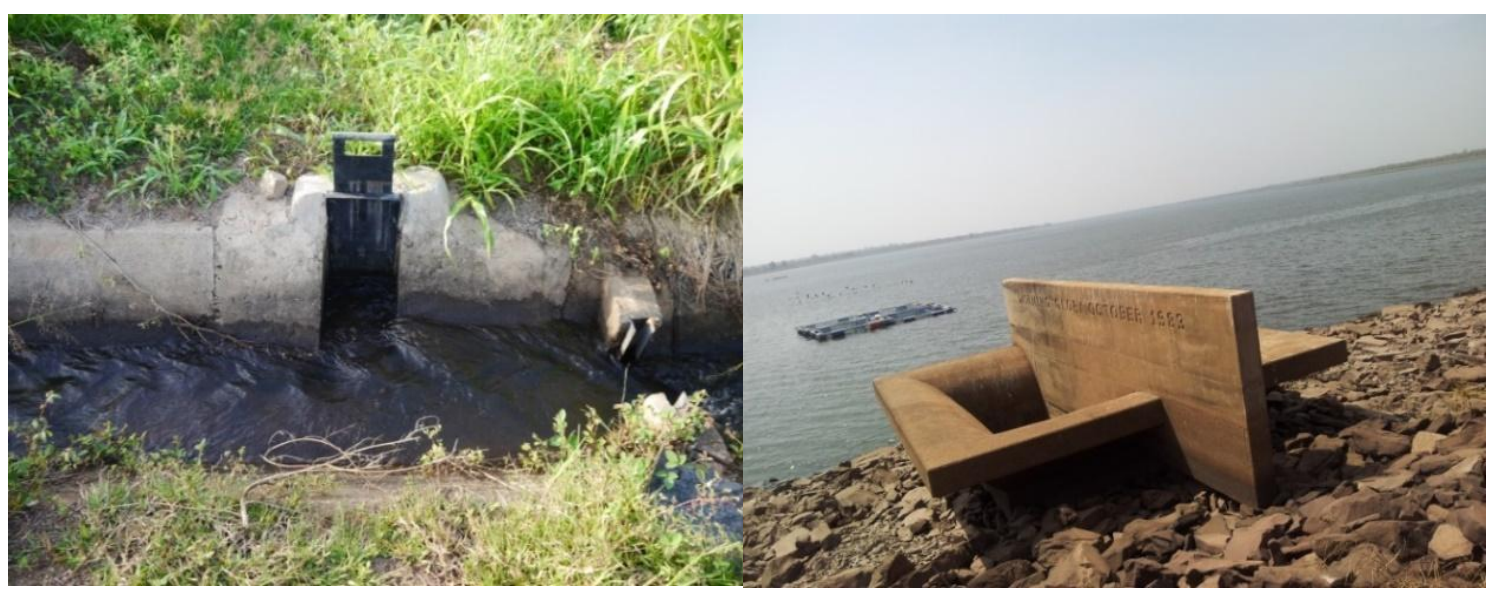

Figure 7.15: Bontanga Irrigation water sources

Source: Author's fieldwork, 2014

In this example, we see the creation of a hybrid system of governance, where farmers and irrigation authorities work together to maintain the proper functioning of this site and access to resources. Farmers are enrolled into this new system by being provided with land and water over which they can have control.

\subsubsection{Maintaining water access from government agency and private owners}

The only government institution which supplies urban Tamale with potable water is the Ghana Water Company Limited, as already mentioned above. Interviews held with officers of the Ghana Water Company (GWC), reveals that even though they prefer vegetables irrigated with clean water, they do not favour the use of potable water for irrigating vegetables in the dry season. The present public relation officer during an interview stated that getting an alternative water source is a better option, even if this might prove difficult, as potable water is strictly for domestic, not agricultural, use as water scarcity is still a problem in Northern Ghana.

Access to good quality water by farmers (which meets World Health Organization standards) is restricted only to the Gumbihini old and new dam sites. Access to this water source, as explained in Chapter 6, is through farmers' collaboration and cooperation with the 
Urban Agricultural Network (Urbanet) and the University for Development Studies. To maintain access and control over the water, they are expected to pay per their consumption bills each month, and if they fail to pay, the water supply will be stopped until the bills are paid. On the other hand, farmers in other open space sites such as Choggu have informal arrangements with private landowners. These informal arrangements usually entail the landowners contracting water for domestic use then later giving it out to farmers to use for their commercial farming, as explained in Chapter 6. Maintaining such an arrangement entails faithfully paying one's bills every month, as this promotes trust between the landowners and the farmers, paving the way for more productive negotiations in the future.

During an interview with a GWC officer from the commercial department I was informed that, in 2012, the company realised that an excess amount of water was not accounted for. It was clear that water meant for domestic purposes was being used for commercial purposes or unofficial pipes had been connected to people's houses which were not formally accounted for. A task force was then sent out to resolve this problem by finding the defaulters and bringing them to book. The report from this exercise revealed that backyard vegetable farmers were more involved in this illegal activity than open space farmers. Many defaulters were charged a fine and the water category changed from domestic to commercial. Interviews with backyard vegetable farmers and some open space farmers revealed that maintaining access to domestic water for commercial purposes, even though illegal, is still possible. A farmer in Gurugu said:

When they come I do talk politely to them and beg them politely that I am trying to meet ends need, but anytime I beg them sometimes they make as if they don't agree or they are not all that happy and when they go they do not say anything until when they come back, and they will talk again, and I will plead again, so that is how I do it.

Others have different strategies, including building a shower house outside and connecting it to the backyard farm. This way, when the task force units come, the farmer points out that water from showering flows into the backyard farm, and that he does not use pipeborne water to irrigate his vegetables.

Maintaining access to water has a lot to do with financial capital and good negotiating skills. It involves convincing others and making them see the need for you to continually get access to a resource, even when it is done illegally. Farmers draw on development discoursed using words such as 'livelihood,' 'survival' and 'poverty' to convince other actors to let them maintain their access to resources like water. The act of participation and willingness to learn paves the way for continual access to water through civil society initiatives and projects like 
that of New Energy and Urbanet in different vegetable sites like Fooshegu and Gumbihini. It is important to mention here that in the city where access to water depends greatly on government initiatives one has to be prepared to pay for services, as networks and associations only reduce the burden, but do not wipe away the cost of using, for example, pipe borne water.

\subsection{Maintaining access to seeds}

From interviews and observation in the field it became clear that farmers relied to a great extent on self-saved seeds when cultivating traditional vegetables, such as Hibiscus sabdariffa, Corchurus olitorious, Amaranthus spp and Abelmoschus esculentus, while a minority of farmers used improved, open-pollinated seed varieties. Improved hybrid and open pollinated seeds are used by farmers when cultivating exotic vegetables like Brassica oleracea, Lactuca sativa, Cucumis sativus and Capsicum spp amongst others. Improved hybrid and open pollinated seeds are bought every season due to the inability of these vegetables to produce seedlings in the tropical climate. In this section, I will explain how farmers maintain their access to improved hybrid seeds and improved open pollinated seeds as well as saved seeds. The examples here will clarify data already discussed in Chapter 6 on how seeds are accessed and will also explain how access to these seeds is controlled and maintained by farmers.

\subsubsection{Maintaining access to hybrid seeds}

Farmers maintain access to improved hybrid and open-pollinated seeds through patronising the same agro-dealers, where they might get seeds at a cheaper rate due to personal familiarity or they can at least count on finding the seeds they need. They also maintain a good relationship with the agro-dealers by referring other farmers to these shops. They always call the agro-dealers on the phone for advice, and, in some cases, to appreciate a product which worked well in their fields.

Maintaining access to improved open-pollinated seeds like Amaranthus spp and Hibiscus sabdariffa is possible when a farmer agrees to plant these seeds during field day trials organised by agro-dealers, then later saves this seed for the next planting season. Also, taking part in such an activity gives farmers not only access to seeds but also an opportunity to build a relationship with the agro-dealer over time. If the experimental plots, as shown in Figure 7.17, perform better than the plots where locally saved seeds are used, the farmer's colleagues will demand where he got his seeds. In referring his colleagues to the agro-dealer, he will be solidifying their relationship and will stand a better chance of always getting free seeds to showcase the products of the agro-dealer. In addition, due to agro-dealers' cooperation with national and international NGOs, where they provide them with inputs for their different projects, farmers who have a good relationship with agro-dealers can be passed on to these NGOs as expert farmers and will benefit from free inputs such as seeds and farm training. 


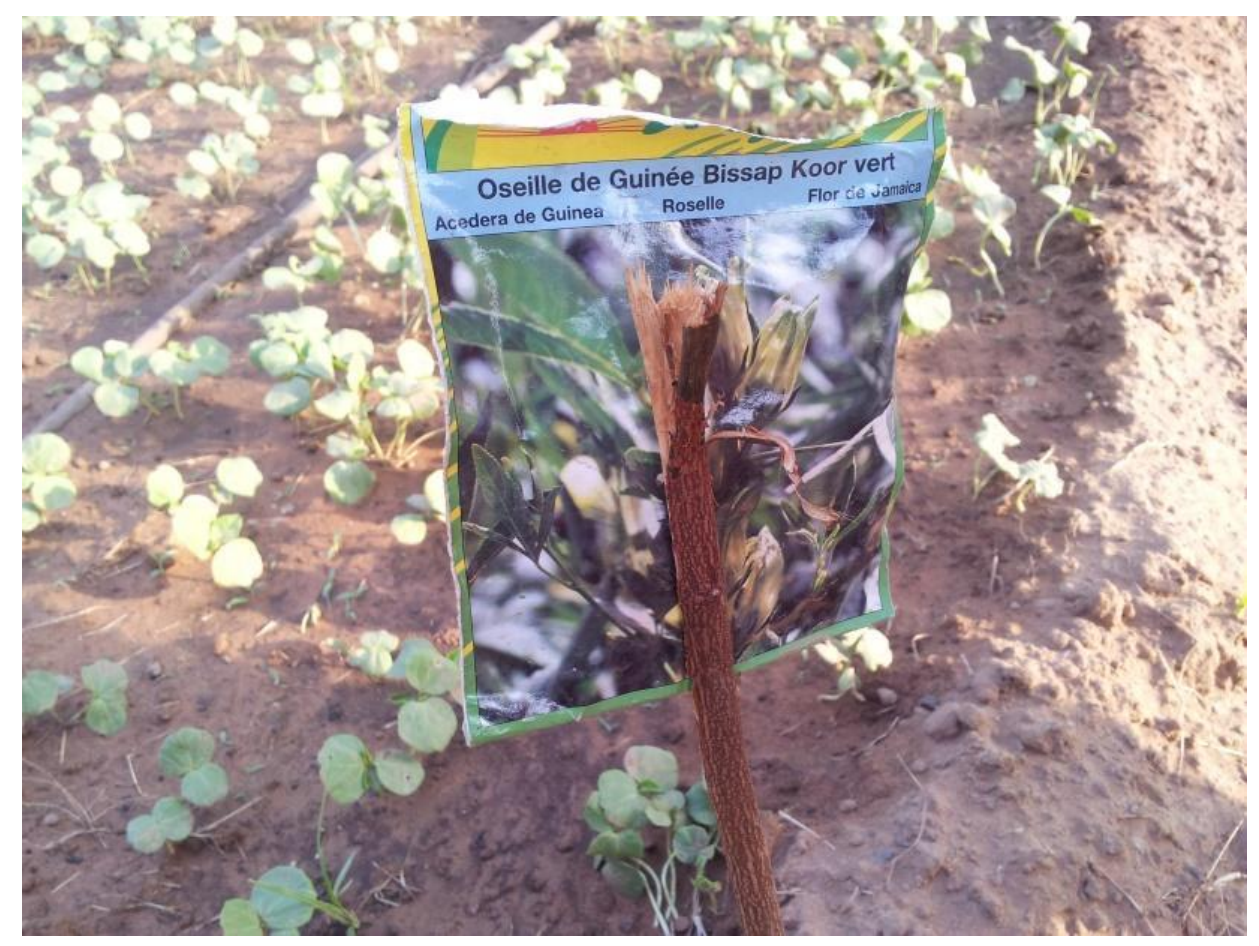

Figure 7.16: An experimental plot in Gumbihini new dam site

Source: Author's fieldwork, 2015

In this example, it is clear that maintaining access to seeds is a combination of creating and maintaining good relations and also having access to credit or money to buy the inputs from agro-dealer shops. This is because a good relationship can give one access to any seed, but maintaining access to this resource requires capital. This focus on improved seed is possible because of the penetration of agro-dealers into the smallholder landscape, coming as part of the policy push towards commercialising agriculture through the agribusiness sector in Ghana and Africa as a whole.

\subsubsection{Maintaining access to self-saved seeds}

There are many ways farmers can gain access to and maintain control over saved seeds. This could be through self-saved seeds or buying seeds from the market. Most farmers harvest seeds and preserve them for the next season. They maintain access to these seeds through continual cultivation and preservation. Farmers also rely on their colleagues, family, and friends when they do not have seeds for the next season. The availability of seeds will depend on a cordial relationship between the farmer and his peers. It could be maintained, for example, by providing them with farm produce as appreciation for providing him with seeds during the planting season. Most farmers grow their seeds in the rainy season and preserve them for use in the dry season and next rainy season. 
Furthermore, some farmers continually get their seeds from other farmers' fields in the rainy season. During a focus group discussion in Datoiyili, one of the farmers explained how they access seeds for indigenous vegetables. He said:

Yes, errh we are now talking of ayoyo, bra and then okra. For these three crops errh, we normally get the seeds from within our own farms. Ayoyo for example is sometimes grown in the rainy season. It can be sown on one's farm land or grow wild in another farm. In the case where it grows wild in another farmer's field, and bears fruits, you can harvest it and later sow it in your field. The same thing to errh bra, somebody may plant the bra on his farm and then after harvesting, leave it to flower and bear fruit. If the person doesn't harvest the fruit, you go and harvest it. Sometimes too you will not get the quantity you want and you go to the market women to get more seeds... my brother is saying that errh though they will get seeds for themselves but errh minister of agriculture is encouraging them to use the exotic errh seeds that they have like okra, ayoyo or bra. Sometimes they sell these seeds in the stores... errh agric is encouraging them to be buying them from the store instead of going to the farm to harvest it and later sow.

From the above quotation, we gather that not all farmers harvest and preserve seeds themselves; some buy these seeds from other farmers believed to have high yielding seeds. Others go directly to the market in search of seeds depending on the money they have at their disposal, while some farmers gather seeds from uncultivated fields. In addition, the Ministry of Agriculture is also discouraging farmers from using self-saved seeds and encouraging the use of commercial seeds sold by them or agro-dealers. Mohammed, a farmer in Gumbihini, claims that he always buys Hibiscus sabdariffa seed from Nabanduri, a town fairly distant from Tamale. During our interview, he mentioned that many farmers grow Hibiscus sabdariffa in Nabanduri and competition between the growers had improved the quality of the seed and made access easier. To maintain access to these seeds, he needs money to buy them each season and store them for continual use during the dry season. Here, maintaining a supply of these seed requires financial capital as well as connections to other farmers in this area.

From interviews with farmers, the general perception is that more than $80 \%$ of seeds used in vegetable cultivation are saved seeds, while improved hybrid and open pollinated seed varieties account for about $20 \%$ of the seeds used, these being mostly obtained from agrodealer shops directly or through projects initiated by non-governmental organisations and local researchers. Many farmers rely on their relationships with their colleagues, family, friends, 
agro-dealers, local researchers and Non-Governmental Organisations and financial capital to gain and maintain access to seed.

\subsection{Conclusion}

This chapter triangulates information presented in Chapter 6 but goes further to show how resources accessed by farmers are maintained or controlled. We see clearly from the examples above how farmers ground and talk claims through the use of technologies like fences, discourses, historical recollection, uprooting boundary markers on their fields, pulling down buildings and using solar irrigation to reconstruct their rights over resources. Grounding claims were mostly carried out in the fields while talking claims resulted when the claims were contested, in a meeting to resolve the problem. For example, the 2007 meeting between the farmers, chiefs, Mayor, land agencies, security unit, land developer and Urbanet on whether lands at Gumbihini can be sold by chiefs reshaped access and property rights to resources, exemplifying a case of talking claims.

Due to the conflict over land sales at Waterworks between Chief Nabila and Luguterah, we see how government statements and policies can outlaw legal practices and even nullify established rights. For example, the judiciary system had decided to sell government land in a green zone to reimburse an estate developer who had no right to buy land for residential purpose in this area in the first place. These ambiguities within government agencies have opened up spaces within which many actors can reconstruct land ownership and control.

Resource access and control are mediated by power struggles and relations between the traditional and state governance systems through which farmers gain use rights over resources. This is explained through farmers' shifting alliances between traditional and state agencies in order to gain access and maintain control over resources. In cases where alliances with traditional or state agencies did not work out in farmers' interests, farmers moved on to make alliances with Non-Governmental Organisations. Technology also mediates the process through which farmers legalise non-governmental organisations. These contradictions in allocating the right to different parties bring flexibilities into the means of transfer and leave room for resource users like farmers to invest in relations with the resource owners to maintain their access (Ribot and Peluso, 2003).

The introduction of international Non-Governmental Organisations or national NonGovernmental Organisations with international backing and interest has led to the reconstruction of land rights and interests in irrigation sites. Women who traditionally could not access land except through a male member of kin now have not only access but rights to land in irrigation sites. Here we see how actors use different strands of law to legalise their control over resources as legitimacy changes over space and time with farmers being co-governors with the state on irrigation sites. 


\section{Chapter 8 - Conclusion: Urban Farming in a Growing Afri- can City}

\section{Introduction}

This study was carried out in Tamale, where the preference for vegetable dishes in everyday cuisine can be noticed from the increasing variety of vegetable dishes in different homes and many public food outlets. This new trend in vegetable consumption has been attributed to the changing diets of the urban middle class (Saavedra et al. 2014). As analysed in previous chapters, urban and peri-urban farmers have built relations through which they can negotiate with, cooperate with and manipulate other actors or groups of actors to have access to and control over resources necessary for vegetable farming in the city. My findings from Chapters 6 and 7 reveal that farmers find themselves in precarious situations of uncertainty and ambivalence as they negotiate access and control over critical resources such as land, water and seeds for dry season vegetable cultivation.

In this concluding chapter, the contribution of this study to theory and science will be elaborated upon and my findings will be situated within the context of resource politics in Africa. This is especially relevant, considering recent calls from the Food and Agricultural Organisation and the United Nations Development Programme for a sustainable, greener and resilient city in Sub-Saharan Africa and the world as a whole. Lastly, I will outline practical and policy recommendations for sustainable urban agricultural practices within the current land tenure system in Northern Ghana.

\subsection{Urban Agriculture in a globalized city}

From discussions in the previous chapters, urban agriculture is an activity that has been practiised for centuries in many African towns (Gyasi et al., 2014). Even though it has existed over a longue durée it has rarely been considered by modern African states as a legal activity (Giweta, 2011; Lee-Smith, 2010). In Tamale, the explosive population growth and the lucrative land market have created many challenges for farmers accessing resources for their agricultural activity, especially in the city. Some of these challenges include an $8.3 \%$ decrease in the spatial extent of land allocated to urban agriculture in open spaces over the last six planting seasons from 2008 to 2014 as explained in Chapter 1 and shown in Figure 8.1, water scarcity and the need for quality seeds. 


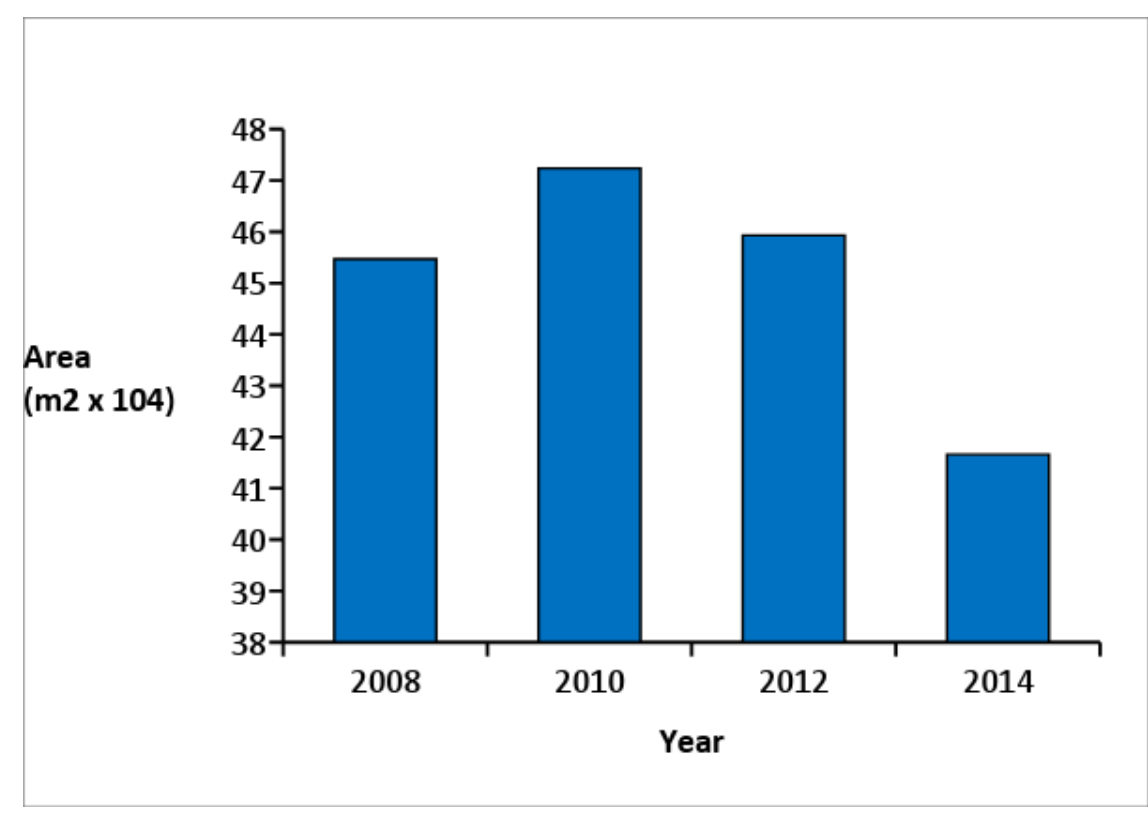

Figure 8.1: Total cultivated open space vegetable sites in Tamale over the past six years Source: Author's fieldwork, 2014/2015

Simultaneously, these relationships have also created opportunities for farmers to utilise markets, technology and partner institutions to network and negotiate access to necessary resources for their agricultural practice.

In Chapters 6 and 7 I have shown how farmers, through interactions in their different social settings, have created relationships and networks with many actors and institutions and, through processes of negotiation, cooperation, resisting and manipulations, have gained and maintained access to resources needed for their practice. An agricultural technician, during an interview, attributed farmers' problems of access and control over resources to the changing attitude of chiefs. He says chiefs have failed in their responsibility and obligations as land trustees for the people, but are reallocating farmlands to estate developers. He also said:

They do not want to sell it (land) to the indigenes. The indigenes will never allow it as it is their inheritance, how can one buy his inheritance. But the chiefs are ungrateful beings? they have not been very fair to the people... They sell the land out for other purposes... to the people who come from elsewhere who are not from this community. They will come and hide and before you realise it they will go and make the land papers at the Town and Country Planning and then come and the chief signs as having given his consent to the allocation of land. 
The quote presented above touches upon one of many issues I have analysed throughout this thesis. It touches on the dynamic and uneasy relationship between state land institutions and the chieftaincy institutions, where repeated state intervention on land matters only seems to increase the existing ambiguity and stil exist today, as explained in Chapter 5. The conflictual relations between the chiefs and farmers are brought to the fore, as chiefs continually sell land used for farming for personal gain as a result of the increasing value of land markets, of which they are also a part. This quote, like others discussed in this study, represents discourses used by the different actors, stemming from historical recollections or even laws, in contesting land claims and staking their own claim over land. When these discourses or historical recollections are legitimised by politico-legal institutions or the society as truth it gives the actor using them legitimacy in their claim.

\subsubsection{The dynamics of continuity: the struggle for self-government and its link to resources}

As I mentioned in the previous section, farmers are struggling to gain access to and control over land for farming in the face of increasing opposition from the chieftaincy institutions and the state, who also lay claims to these lands. The immediate cause of one instance of these conflicts, shown in an extended case study in Chapter 7, occurred when a building structure on a vegetable site in central Tamale was demolished by farmers. This incident made clear the struggle for power and authority over public land between farmers and the chiefs. In this case, farmers resisted the power and authority of the chiefs and solicited support from the state and a Non-Governmental Organisation, using the planning law, which states that areas designed as green belts should not be sold for estate development.

The influence of chiefs over public lands has been shaped historically from the precolonial to the contemporary era, where the chieftaincy institutions after the pre-colonial era gained control over lands. From this period onwards chiefs have shared their power and authority over land with different government bodies in colonial and post-colonial eras. This relationship has always been an uneasy one, as chiefs wanted to maintain complete control over land. The new governments only created additional external land agencies to mediate chiefs' control over lands, which led to further ambiguity and overlaps in land use and management, as discussed in Chapter 5. Customary lands stayed under the control of the chieftaincy institutions and government with shifts in power and control over time and space during different government regimes. Presently, the 1992 Constitution gives the chieftaincy institution complete control over chieftaincy matters such as land, leading to chieftaincy struggles over those public lands, where chiefs ask that these lands be given back to the chieftaincy institution because they are not used by the government for the purpose they were acquired for. Land is a Dagomba man's identity, socio-cultural life, and means of livelihood, but with chiefs' rapid 
sales or allocation of land to estate developers, a Dagomba man could become a 'landless man'. In Chapters 6 and 7, I demonstrate how land disputes between the chiefs and farmers on public land provide the chiefs with a platform from which to address the state's growing authority on land. The compulsory land acquisition act has given chiefs an important foothold in public land in their struggle for authority over the state on land matters.

The importance of controlling land has become a quest for power and authority between chieftaincy institutions and state land agencies. These contestations over land administration and control have evolved historically and are evident in the chiefs' growing concerns about how land should be used and managed. In Chapter $5 \mathrm{I}$ explained how state interventions aimed at rendering customary law 'legible' through land administrative policies and institutions have, in effect, made land tenure rules more ambiguous and open to interpretation. The efforts to change towards unambiguous clarity bring about a counter movement for "exceptions, fluidity, imprecision and uncertainty" (Lund, 1998: 11). The confrontation between the resource users and politico-legal institutions, between the resource users themselves and between the politico-legal institutions themselves are all part of the process of governing resource access.

After independence, as interventions increased and new governing actors, such as missionaries and NGOs, arrived on the scene, securing territorial control increasingly appeared to inform the practices and strategies of chiefs in Tamale. In Chapters 1, 5 and 6 I discussed the emergence of this pattern by showing how chiefs reconstructed the tradition and even used statutory laws to maintain control over lands for their interest. Gradually, however, interventions by the state to acquire land through compulsory acquisition using the power of eminent domain became problematic, as these lands were never given back to the chiefs when they were no longer being used for the purpose for which they were acquired, as indicated by law. This has challenged the chiefs" political leverage and much of their authority to govern land.

In the presence of ambiguity and plurality in land administration and control, farmers have been able to negotiate their access to resources such as land, water and seed and maintain control over them through networking with researchers, educational bodies, NonGovernmental Organisations, some government officials and even senior chiefs. They have also created and maintained social relations which have given them access to technologies such as drip irrigation, greenhouses, irrigation solar panels and fences which they have used to stake claims to resources and gain legitimacy for their agricultural practice. 


\subsubsection{A transnational arena of governmentality and political struggle}

The dynamics outlined in the previous sections are themselves part of a larger historically produced arena, the analysis of which brings to light issues of governmentality, political struggle and social change. To delineate the contours of this broad arena, I have combined insights from Foucault (2001), Li (2007b), Scott (2009) and Ferguson and Gupta (2002). Foucault $(1982,2007)$ and Dean (2010) used the term "governmentality" to analyse the form of power that is inherent in government to bring about calculated change, which can have varying effects on the government's subjects. Governmentality denotes a practice that aims to shape people's behaviour. This study has benefited from this broad concept of governmentality, used to explain a broad range of interventions (for example land administrative policies, agricultural practices, etc.) as well as the counter actions of other actors - like chiefs, farmers, and land developers who sometimes accept and resist these forms of governmental interventions. The tendency in the Foucauldian-inspired governmentality literature has been to analyse how governmental power is contained in governmental interventions. Li (2007a) has taken this analysis a step further by also looking at the effects of governmental interventions as they articulate within existing relations, practices, processes and struggles. Like $\mathrm{Li}$, this study also analysed the articulations and the effects of governmental interventions (see Chapters 5, 6 and 7) by incorporating the governing practices and political strategies of all actors embedded in urban farming to capture all the relevant forces of power at play.

Scott's (2009) historical study of Zomia (upland Southeast Asia) in The Art of Not Being Governed is useful in pinpointing more precisely the nature of some of these practices and strategies found in this study. Scott describes the social practices that were adopted by the inhabitants of Zomia to avoid being governed, for example practicing shifting cultivation instead of irrigated farming in the lowland area. For a long time, increasing governmental interventions over time have triggered political strategies adopted by chiefs to avoid being governed by the state (see Chapter 5). They are not passively accepting the interventions that target them, but are instead actively and strategically negotiating and co-governing with the state. Similarly, farmers are also resisting the chieftaincy's attempts at control over and intervention in their use of government lands, as explained in Chapters 6 and 7 of this study. They have succeeded so far by building alliances with the state and NGOs to retain access to and control over undeveloped public lands, especially in Gumbihini. This shows that actors, as a result of their diverse interests, can accept being governed or resist it depending on their agenda. Through these processes of resisting and accepting a governmental intervention, governance is created every day, as explained in Blundo and Le Meur (2009) and Olivier de Sardan (2015), and redefined over time by the subjects according to Sending et al. (2006).

$\mathrm{Li}(2007 \mathrm{a})$, describing the case of the Free Farmers Forum in Indonesia, described how farmers' actions, in word and deed, conveyed claims of sovereignty and self-government. 
In Chapters 6 and 7 I showed how farmers' actions in a central Tamale vegetable site manifested their resistance to traditional governance, embracing a self-governance structure dependent on shifting alliances with non-governmental organisations, the state and some senior chiefs. Here, farmers exercised authority in the land dispute meeting by invoking the legal and vernacular laws which were favourable to their cause, with assistance. The political struggle towards self-government and not being governed by the state, Non-Governmental Organisations and senior chiefs completely, shows that governmentality is layered and multifarious with transformative effects on institutions, livelihoods and identities, which occur as different forms of governing systems intersect, overlap and articulate over time. In this changing context, subjects slowly come to define themselves and their roles in relation to the state and other governing institutions as they increasingly make their presence felt.

In Chapter 5, I spelled out how the introduction of the Land Administration Project (LAP) - a governmental intervention - took shape in practice. The LAP is meant to institutionalise all land agencies and create a Customary Land Secretariat (CLS) to ensure accountability in land transactions. This intervention targeted chieftaincy control over land, which is not considered accountable due to the many problematic land cases that have arisen, such as that involving the Gumbihini chief and Luguterah. Chiefs are also fighting to maintain their control over land matters by appointing a CLS whom they believe has their interest at heart. The LAP has shown how governmental interventions and the practices of leaders are increasingly becoming interlocked. Secondly it highlights the complex and shifting alliances and networks of differently positioned governing actors like the World Bank, Department for International Development (DFID), Canadian International Development Agency (CIDA), Kreditanstalt fur Wiederaufbau (KfW), German Technical Assistance Corporation (GTZ), Nordic Development Fund (NDF), the government of Ghana and the chieftaincy institution in shaping land use and control. For example, the World Bank's interest in the LAP relates to their keenness to see the creation of a market-driven land system where people can have access to individual land titles or leases. The Department for International Development is interested in a transparent customary land tenure system. These different organisations similarly use the land issue and the LAP as a forum within which to legitimise their ideology and their philosophy on property rights in Africa and the world at large.

The same amount of differentiation that Li (2007a) affords to her review of governmental interventions in Indonesia - i.e. by showing the variety of actors and institutions involved, their alliances and their struggles and the different, sometimes contradictory, ways in which they operationalised their projects and programmes of intervention - also needs to be extended to the governing practices found in dry season vegetable farming in Tamale. The entire range of actors, from farmers and government agencies to estate developers and chiefs, have varied interests and agendas which change over time. It follows that different farmers engage 
differently in the struggle for resources, some through alliances with other actors, becoming co-governing partners, while others refused to be governed at all.

This thesis has shown that, in order to understand the articulations and effects of governmental interventions, it is not only important to incorporate practices and strategies of the governed and ungoverned into the analysis, but also to pay attention to internal political tensions and dynamics in this era of transnational governmentality and political struggle. Both continued autonomy and profound changes are best understood by situating them within the historically formed transnational arena of governmentality and political struggle.

\subsubsection{Capturing societal change}

This thesis captured an image of a society which has evolved historically and is still changing as a result of its socio-political setting. This enabled me to see change happen through my extended case study - by focusing on what actors do, why and how they do these things and also witnessing snippets of law-in-the-making. Exploring the overlap of governmentality and political ecology made this theoretically possible. Governmentality is about calculatedly changing and shaping the conduct of people and, in this way, making new subjects (Agrawal, 2005; Bevir, 1999; Bose et al., 2012). By focusing on the changing strategies of actors, including how new rules are made and later internalised, this study captures subjects-in-the-making, as will be expanded on below in 8.1.5. This study, as stated in the introductory chapter, is concerned with understanding the changing ways in which farmers engage with resources (land, water, and seed), and with each other in relation to these resources, to produce vegetables in the city.

Political ecology approaches socio-environmental change as a political process. What governmentality and political ecology have in common, and what bodes well for their compatibility, is that they both engage with questions of power relations. Governmentality studies link with political ecology in this study as I try to understand the changing strategies of actors and subjects-in-the-making as political processes. The paradox is that, by strategizing so as not to be governed, chiefs and farmers inevitably change as subjects. For example, when a farmer solicits the services of the state through an alliance with a non-governmental organisation, as explained in the extended case study on land access in Gumbihini, he adopts the role of a political client. When farmers switch from one relationship to another or create new alliances and networks by 'shopping' for forums in one institution or the other, their interest not only gets legitimised, it also becomes a social norm with socio-political implications for resource access as a whole.

Methodologically, social change was captured by an extended case study of the practices and strategies of farmers in relation to access and control of resources, which laid the 
groundwork for Chapters 6 and 7. By looking at the changing strategies and practices of particular actors - chiefs, farmers, NGOs and the State - I have demonstrated how they are a manifestation of wider processes of societal change (see Chapters 6 and 7). New resource access rules were reinvented and internalised, especially on irrigation sites, where women can now directly get access to their own plots of land through gender-sensitive agricultural projects. This is a unique case in the Northern region as, historically, women's sole access route to land has been through men who also control this landed property (Nchanji and Bellwood-Howard, 2016a). Men in possession of plots of land continued passing lands to younger generations on irrigation sites as they retired instead of giving the lands back to the State as a result of a unique hybrid governance system on these sites (Nchanji et al., 2016b). Furthermore, we also see how uneasy relations between chiefs and the State in land administration and control has led to the chieftaincy institution not only ignoring state land rules but also rezoning and reallocating public land which is under control of the state and managed by the Lands Commission. They are succeeding in doing this by mobilizing discourses on state failure in order to give them back lands acquired compulsorily when they are no longer used for the purpose they were acquired for. This is made possible as a result of overlaps and ambiguity between different government institutions like the courts and the Lands Commission. The courts have legalised chiefs' authority over green belts, for example, by passing judgement to auction a green belt plot and pay the estate developer it was sold to.

Land dispute meetings act as political arenas (Lund, 2006) where practices and strategies of land contestation and claims by chiefs, farmers and the State take place. They are also an arena where politico-legal institutions legalised an actor's authority in gaining access and control over resources like land over another. In this arena we see how one governance system is chosen over another to suit an actor's interest and, in doing so, this actor takes part in shaping how governance is implemented. In this way, actors are not only mediators of externally imposed change but, as governors themselves, they also shape and direct change by, for example, by formulating new rules, most visibly during meetings. For instance, chiefs had to accept farmers continuing to farm on public lands which were not under their control or allocated for residential purposes. Chapters 6 and 7 also argue that the rules agreed upon in meetings also changed with time, as chiefs who agreed to let farmers cultivate on public lands in Gumbihini later tried to sell this same lands as new chiefs were enskinned after the death of former chiefs. Meetings turned out to be rare events for observing change. They were local arenas where problems were discussed and negotiated, and compromises were sometimes reached. For example, in Chapters 6 and 7 I showed how farmers are now bypassing chieftaincy institutions and reaching out to the State's legal system directly to lay claims on land, since chiefs are selling agricultural lands cultivated by farmers. This move by farmers legitimises the State and gives it the power to challenge the authority of the chiefs on the said lands 
was done to meet their interest. In this thesis, I made use of a historical perspective, studying over time all the actors involved in the struggle over resources (the chiefs, the farmers, NGOs and the State) as they argued in meetings in order to obtain a comprehensive picture of the factors which contribute to these continual changes in resource use and control. This demonstrated that institutional changes could be captured by taking a historical perspective when analysing people's motives, practices and strategies in the arena of meetings.

\subsubsection{Property-in-the-making}

As explained in the above section, the historical perspective on the practices of actors, including anticipation and future planning, made it possible for this study to capture how property is being 'made' in Tamale. I have argued throughout this thesis that property claims are all about negotiations, persuasion (Rose 1994) and communicating territoriality (Ingold 1986). By describing how people 'ground' claims (for example, building a fence) and 'talk' claims (in land dispute meetings), I demonstrate that land that was open for all to farm is increasingly being claimed by chiefs and sold to individuals as their exclusive property. This act by the chiefs can be interpreted as a move towards an individualised land titling system promoted by the chiefs. In addition, farmers are also claiming public land for individuals and clans. This is property-inthe-making and in analysing this dynamic, this study makes a theoretical contribution to illuminating the 'grey zone' between access and property (Sikor and Lund, 2009). The grey zones are visible in the extended case study, where we see how claims made on land have been appropriated as property by actors such as farmers and chiefs who do not have any 'rights' to public lands.

Some conceptual and theoretical clarification is needed here. The process of propertyin-the-making in Tamale is not part of a formalisation process in the sense that customary tenure is made official through state-sanctioned, legally protected written documents (Benjaminsen et al., 2009) neither is it a semi-formalisation, nor an informal formalisation of property (ibid: 30,32 ) and it is also not an informalisation of formal tenure transformation (Matter, 2010a). Instead, it is about individualisation and consolidation of property claims in line with the farmers' construction of tenure practices and arrangements which suit their interest. Although the process of individualisation occurs outside the formal state structures of tenure reform, it is not entirely an 'autonomous evolution' driven by population growth, land scarcity and the commercialisation of agriculture (Platteau, 1996). It must also be seen in the changing context of political struggle and transnational governmentality that increasingly puts pressure on the government, chiefs and farmers, and highlights the need to secure claims.

The point is that, in the past, the concern was the ability to use land, not to hold it, even if this was done collectively (Colson, 1971). This is a subtle but important nuance. Holding means having rights while controlling can be achieved if one has the ability to do so and not 
only a right to do so. In some sites in Tamale, it was not about holding land collectively but about belonging to a group, because access to land was pre-dictated on membership of a group that controlled land (van Dijk, 1996). It is thus not about holding or owning lands as common property but about being able to benefit from them continually - and maintain access to them in any way possible (see Chapters 6 and 7). Property presupposes clear boundaries but, as we have seen throughout this thesis, Tamale's territorial control has changed over the years. The theory of access, with its focus on the ability to benefit from natural resources (even by using force) and its three dimensions of gaining, controlling and maintaining access (Ribot and Peluso 2003) best captures the concern about using resources including land in Ghana and many African countries.

Rather than a transition from common property to individual property, property-in-themaking in Tamale, therefore, reflects changes in tenure practice where access regulates the use of land and how property is made. The focus is on 'what people do' and not 'things' which are there or not as indicated in Juul and Lund (2002). This study demonstrates how property is being made and analyses the differences and changes from access to property. Propertyin-the-making is most pertinent in the arena of the land dispute meeting where claims are 'talked' (see Chapters 6 and 7). The 'making' here comes from the interaction of the various actors, each of whom have their own agenda. The disputants and their supporters 'talk claims' and are preoccupied with the concrete case at hand, and the mediators who govern appropriation are concerned with categorical property, i.e. the rules that define what is legitimate property or not. The practice of 'talking claims' and governing appropriation are phenomena governed by concretised social relationships and the legal-institutional analytical layer of property (Benda-Beckmann et al., 2006) as discussed in Chapter 2.

Land dispute meetings are thus political arenas where interaction between these different analytical layers of property occur and change over time as the actor's change. It is in this process of interaction that property is negotiated and laws co-constructed for future implementation. During these negotiation processes in land dispute meetings, old rules are discarded or adjusted, new rules are formulated and hybrid arrangements between them are negotiated (Chapters 6 and 7). Property-in-the-making is about rules-in-the-making, too, because these rules form part of a repertoire of regulations, procedures, and prescriptions that together re-construct customary and statutory land laws in Tamale.

\subsubsection{Governance and Subjects-in-the-making}

According to Rose et al. (2006) there has been less focus in the literature on subject formation and the effects of governmental powers on the subjects. The effects of governmental interventions on subject formation are multifaceted, with subjects endorsing and resisting government projects or interventions that target them (Agrawal, 2005; Bose et al., 2012; Li, 2007a). 
Studies like this raise important ideas as to the docility of the governed (Merlingen 2006), and the incapacity of government practices to sometimes produce the change they seek (Inda, 2005). This is because subjects interact, intentionally or unintentionally, as they attempt to exert influence on each other or other actors. Simultaneously, subjects react to such attempts, by resisting, changing or endorsing them, thereby shaping governance within a given context (Sending et al., 2006). This shows that outcomes of governmental interventions are unpredictable and this unpredictability often leads to a co-construction or reshaping of governance systems inherent in dynamic situations such as urban farming (see Chapters 6 and 7).

As argued in Chapter 3, farmers have been subject to many interventions over time from the pre-colonial era to the present. During these different time periods, they have undergone different changes by either accepting the interventions of the chiefs or State in their agricultural activity or refusing to do so. Farmers have traditionally adhered to the customary system of land ownership which accords them use rights over land. Increasing urbanisation and development interventions have brought about changes in farmers' activities as the city infrastructures have taken over their lands. Some farmers have moved to peri-urban areas in search for water bodied lands to farm while others have put in place different strategies to maintain access and control over the lands they have in the city. The alterations made by farmers to these different interventions of chiefs or the state are the effects of interventions on them as subjects.

The process of seeking fora or institutions which are more likely to favour one's interest is what is referred to as forum or institutional shopping by Benda-Beckmann (1981) and Bierschenk and Olivier de Sardan (2003). The process of seeking different fora within a forum or moving from one forum to another gives the subjects the opportunity to be active in shaping how governance is enacted (Sending et al., 2006). Bierschenk and Olivier de Sardan (2003) show how governance happens through the actions of various actor groups that are interlinked, yet try to demonstrate their autonomy. Thus, interactions between governance institutions are not always simple cases of cooperation or conflict, but more like processes of mutual reshaping and co-construction (see Chapters 2, 6 and 7).

Through the 'shopping' process institutions are liable to gain legitimacy when actors use their fora (Murphy and Kellow, 2013). In this thesis, NGO's have manipulated disputants' use of them to enhance their legitimacy as governing and fundable organisations. Traditional chiefs also gained legitimacy as land developers bought public lands from them. As argued throughout this thesis, claims brought forth in the different forums often try to undermine dominant discourses or sets of rules by presenting inconsistent ones from elsewhere to challenge the primacy of another actor. This process is what Raustiala and Victor (2004) and Alter and Meunier (2009) refer to as strategic inconsistency. Governmental plurality has allowed spaces 
of ambivalence to emerge, and within these spaces, subjects are cooperating and challenging each other to co-construct the processes of governance.

This thesis has demonstrated that the societal and institutional changes that accompanied and followed governmental interventions went - and still go - together with struggles, conflicts and disputes between differently positioned people. Similarly, changes and transformations in subjectivities, though not necessarily in the direction planned by the governing actors, involve internal struggles, contradictions and a moving around of the "mental furniture" (Agrawal, 2005: 174). The formation of new subjectivities, like the emergence of different social practices, is part and parcel of, and refracted in, the process of governmentality and political struggle. Resource use and access have been reshaped and reconstructed by governmental interventions like land laws and the Land Administration Programme which are meant to govern the chiefs and land users from afar, presupposing that social realities can be programmable and subject to processes that can be acted upon and changed. National and international development agencies are also contesting legitimization in this arena by stating that they know what the people want and can provide it through partnering with them at the local level. This is seen in their reasons often given to different institutions and actors for carrying out their activities.

\subsection{Situating resource politics in Africa}

For centuries, resource access in Africa has been negotiated and reinterpreted by different individual and institutional actors through formal and/or customary laws to serve their purposes using historical moments and geographical scale to state their claims or rights (Ribot and Peluso, 2003). Different historical moments have led to changes in the nature of power amongst actors and forms of access to resources over time, as new claims of legitimacy, rights and benefits are reconstructed and transformed (lbid). The struggle over access and control of resources involves different actors, including private, State, individual and international agencies, each relying on different concepts like those of legitimacy, territoriality, belonging, and public authority to stake their claims (Lund and Boone, 2013).

This trend has not changed in recent years, as customary laws have continually been reconstructed and reinterpreted to meet the interests of different actors implicated in resource access and use. Changing trends in customary land allocation in Tamale show that the customary land is adaptable to changing socio-political realities, but to the detriment of farmers who are losing their usufructs rights over customary lands as chiefs' continual sale of land is becoming problematic.

This thesis, in studying and analysing strategies used by different actors as they claim, contest and redefine property rights, has contributed to broader debates on property rights in 
Africa. It allows for the understanding of how people manage access and control of resources like land, water, and seed in their everyday practice.

\subsection{Recommendations}

Policy recommendations and future research will be outlined below, with the aim of streamlining/improving resource access mechanisms in urban agriculture.

\subsubsection{Further Research}

When a study is carried out, it opens up more areas for study. Analysing processes of everyday governance by urban farmers in accessing and controlling resources for their practice is important, and it raises awareness of other areas of potential research.

1. There is a need for further studies on changes in land use and control after the LAP project has been finalised, to see if it will in any way make chiefs more accountable to their communities in land matters and to a greater extent achieve equal land rights to all.

2. The outward sprawl of urbanisation to peri-urban areas has consequences not only in these areas but also in the rural area. This calls for a study on effects of land markets in the city on rural lands and which strategies farmers are employing to cope with this situation.

3. NGOs have been very active actors in introducing new agricultural projects and reshaping agricultural policy in Northern Ghana, as this thesis portrays. This calls for a need to find out if this change in policy and new technologies in the North has succeeded in the stated aim of increasing food production and security.

\subsubsection{Policy Recommendations}

Many studies have been carried out, but most of them are not integrated into government policies. In a discussion I had with a government official, he stated that research papers are mostly written in the language of scientists and not policy makers. I have decided to outline some policy recommendations relevant to urban agriculture.

1. Public lands which are especially reserved as green belts should be converted to urban farmlands and officially distributed to farmers who already farm there at a fee, which can be used to improve on farmers' practice when needed. If there is no water source, the state should arrange with the Ghana Water Company to provide water for irrigation for a fee, as already exists in two vegetable sites in central Tamale.

2. With the decentralization process, local governments should push their members of parliament to vote for the new planning bill which incorporates urban agriculture. The legalisation of urban agriculture will be a necessary step to renegotiate and solve ownership conflicts on public lands. 
3. New forms of urban farming, such as farming vegetables in sacks and other innovative methods that suit the social reality of the people should be introduced, and farmers' capacities strengthened to adopt them. 


\section{References}

Abdul-Ghaniyu, S., Kranjac-Berisavljevic, G., Yakubu, I. B., \& Keraita, B. (2002). Sources and quality of water for urban vegetable production, Tamale, Ghana. Urban Agriculture Magazine, 8(10).

Acemoglu, D., Johnson, S., \& Robinson, J.A. (2001). The colonial origins of comparative development: An empirical investigation. American Economic Review, 91(5), 1369-1401.

Acheampong, E. N., Ozor, N., \& Sekyi-Annan, E. (2014). Development of small dams and their impact on livelihoods: Cases from Northern Ghana. African Journal of Agricultural Research, 9(24), 1867-1877. https://doi.org/10.5897/AJAR2014.8610.

Adam, M. (2001). Definition and boundaries of the peri-urban interface: Patterns in the patchwork. In P. Drechsel \& D. Kunze (Eds.), In waste composting for urban and peri-urban agriculture: closing the rural-urban nutrient cycle in sub-Saharan Africa (pp. 193-208). Wallingford: CABI.

Adarkwah, Y. (2006). Strengthening customary land administration: A DFID Morld Bank sponsored project in Ghana. Paper presented to the promoting land administration and good governance regional conference, Accra, 8-11 March.

Addo-Fening, R. (1990). The native jurisdiction ordinance, indirect rule and the subject's well-being: The Abuakwa experience 1899-1912. Research Review NS, 6(2), 29-44.

Afari-Sefa, V., Asare-Bediako, E., Kenyon, L., \& Micah, J. A. (2015). Pesticide use practices and perceptions of vegetable farmers in the cocoa belts of the ashanti and western regions of Ghana. Advances in Crop Science and Technology, 3(3), 1-10. https://doi.org/10.4172/23298863.1000174.

Afari-Sefa, V., Chagomoka, T., Karanja, D.K., Njeru, E., Samali, S., Katunzi, A., Mtwaenzi, H. and Kimenye, L. (2013). Pivate contracting versus community seed production sytems: Experiences from farmer-led seed enterprise development of indigenous vegetables in Tanzania. $\begin{array}{llr}\text { Acta } \quad \text { Hortic. } & \text { 671-680 }\end{array}$ https://doi.org/10.17660/ActaHortic.2013.1007.78

Afari-Sefa, V., Tenkouano, A., Ojiewo, C. O., Keatinge, J. D. H., \& Hughes, J. D. A. (2012). Vegetable breeding in Africa: Constraints, complexity and contributions toward achieving food and nutritional security. Food Security, 4(1), 115-127. https://doi.org/10.1007/s12571-011-0158-8

African Development Bank. (2016). Feed Africa: Strategy for agricultural transformation in Africa 2016- 2025. AfDB, Abidjan. Retrieved from https://www.afdb.org/fileadmin/uploads/afdb/Documents/Generic-Documents/Feed_Africa-_Strategy_for_Agricultural_Transformation_in_Africa_2016-2025.pdf

Agbosu, L. (1990). Land registration in Ghana: Past, present and the future. Journal of African Law, 34(02), 104-127. https://doi.org/10.1017/s0021855300008251. 
Agbosu, L. K. (2000). Land law in Ghana: Contradiction between anglo-american and customary conceptions of tenure and practices: Working paper No.33,1-27. Land tenure center. University of Wisconsin-Madison.

Agbosu, L., Awumbila, M., Dowuona-Hammond, C., \& Tsikata, D. (2007). Customary and statutory land tenure and land policy in Ghana. Technical publication no. 70, 1-126. Institute of Statistical Social and Economic Research (ISSER), University of Ghana, Accra.

Agrawal, A. (2005). Environmentality: Community, intimate government, and the making of environmental subjects in Kumaon, India. Current Anthropology, 46(2), 161-190.

Ahorsu, K. (2014). A Poststructuralist approach to the Dagbon chieftaincy crisis in Northern Ghana. African Conflict and Peacebuilding Review, 4(1), 95-119. https://doi.org/10.2979/africonfpeacrevi.4.1.95

Allen, Q. (2012). Photographs and stories: Ethics, benefits and dilemmas of using participant photography with black middle-class male youth. Qualitative Research, 12(4), 443-458. https://doi.org/10.1177/1468794111433088.

Alter, K. J., \& Meunier, S. (2009). The Politics of international regime complexity. Perspectives on politics, 7(01), 13-24. https://doi.org/10.1017/S1537592709090033.

Amanor, K. S. (2001). Land, labour and the family in southern Ghana: A critique of land policy under neo-liberalisation (Research report 116). Uppsala: Nordiska Afrikainstitutet. Retrieved from http://urn.kb.se/resolve?urn=urn:nbn:se:nai:diva-208.

Amanor, K. S. (2005). Night harvesters, forest hoods and saboteurs: Struggles over land expropriation in Ghana. In S. Moyo \& P. Yeros (Eds.), Reclaiming the land: The resurgenge of rural movements in Africa, Asia and Latin America (pp. 117-132). London: Zed Books.

Amanor, K. S. (2007). Conflict and the reintepretation of customary tenure in Ghana. In B. Derman, R. Odgaard, \& E. Sjaastad (Eds.), Conflict over land and water in West Africa (pp. 33-59). Oxford: James Currey.

Amanor, K. S. (2010) Participation, commercialisation and actor networks: The political economy of cereal seed production, FAC working paper 16, Brighton: Future Agricultures Consortium

Amanor, K. S. (2011). From farmer's participation to pro-poor seed markets: The political economy of commercial cereals networks in Ghana. IDS Bulletin, 42(4), 48-58. doi:10.1111/j.17595436.2011. 00235.x.

Anankware, P. J., Fening, K. O., Osekre, E., \& Obeng-Ofori, D. (2015). Insects as food and feed: A review. International Journal of Agricultural Research and Review, 3(1), 143-151.

Anderson, E. (2003). Jelly's Place: An ethnographic memoir. Symbolic Interaction, 26(2), 217-237. https://doi.org/10.1525/si.2003.26.2.217.

Andranovich, G., \& Riposa, G. (1993). Doing urban research. Applied social research methods series: v. 33. Newbury Park, Calif.: Sage Publications. 
Andreas de Neergaard, Drescher, A. W., \& Koume, C. (2009). Urban and peri-urban agriculture in African cities. In C. M. Shackleton, M. W. Pasquini, \& A. W. Drescher (Eds.), African indigenous vegetables in urban agriculture (pp. 35-58). Dunstan House, London, UK: Earthscan.

Appiah, D. (2012). The politics of traditional - federal state formation and land administration reform in Ghana: 1821 - 2010: PhD thesis, University of York, England.

Apusigah, A. A. (2009). The gendered politics of farm household production and the shaping of women's livelihoods in Northern Ghana. Feminist Africa, 12(12), 51-68.

Asante, F., \& Amuakwa-Mensah, F. (2015). Climate change and variability in Ghana: Stocktaking. Climate, 3(1), 78-99. https://doi.org/10.3390/cli3010078

Asomani-Boateng, R. (2002). Urban cultivation in Accra: An examination of the nature, practices, problems, potentials and urban planning implications. Habitat International, 26(4), 591-607.

Asuming-Brempong, S., \& Kuwornu, John K. M. (2013). Policy initiatives and agricultural performance in post-independent Ghana. Journal of Social and Development Sciences, 4(9), 425-434.

Austin, D. (1964). Politics in Ghana, 1946-1960. Oxford: Oxford University Press.

Avornyo, V. K., Baidoo, I., \& Amissah, I. (2014). Effects of more than two decades of irrigation on the physical and chemical properties of two savanna soils at the golinga irrigation site near tamale. International Journal of Forest, Soil and Erosion (IJFSE), 4(2), 38-44.

Ayana, A., Afari-Sefa, V., Emana, B., Dinssa, F. F., Balemi, T., \& Temesgen, M. (2014). Analysis of vegetable seed systems and implications for vegetable development in the humid tropics of Ethiopia. International Journal of Agriculture and Forestry, 4(4), 325-337. https://doi.org/10.5923/j.ijaf.20140404.10

Ayee, J., Frempong, Alex K. D, Asante, R., \& Boafo-Arthur, K. (2008). Local power struggles, conflict and conflict resolution in Ghana: The causes, dynamics and policy implications of land-related conflicts in the greater Accra and eastern regions of Ghana. Research report no. 1. Consortium for development partnerships (CDP), local context of conflicts and peacebuilding retrieved from file:///C:/Users/Eileen\%20Nchanji/Downloads/Ghana_Rep_1-2\%20(1).pdf

Barwa, S. D. (1995). Structural adjustment programmes and the urban informal sector in Ghana (discussion paper 3). Geneva: International labour office, development and technical cooperation department. Retrieved from http://www.ilo.int/wcmsp5/groups/public/@ed_emp/documents/publication/wcms_123422.pdf.

Bates, R. (1983). Essay on the political economy of rural Africa. Cambridge: Cambridge University Press.

Bawumia, M. (1998). Understanding the rural-urban voting patterns in the 1992 Ghanaian presidential election. A closer look at the distributional impact of Ghana's structural adjustment programme. Journal of Modern African Studies, 36(1), 47-70. Retrieved from http://www.jstor.org/stable/161637. 
Benda-Beckmann, F. V., Benda-Beckmann, K. V., \& Wiber, M. G. (2006). The properties of property. In F. V. Benda-Beckmann, K. V. Benda Beckmann, \& M. G. Wiber (Eds.), Changing properties of property (pp. 1-39). New York: Berghahn.

Benda-Beckmann, K. v. (1981). Forum shopping and shopping forums: Dispute processing in a minangkabau village in west Sumatra. Journal of Legal Pluralism and Unofficial Law, 13(19), 117-159.

Benjaminsen, T. A., Holden, S., Lund, C., \& Sjaastad, E. (2009). Formalisation of land rights: Some empirical evidence from Mali, Niger and South Africa. Land Use Policy, 26(1), 28-35. https://doi.org/10.1016/j.landusepol.2008.07.003

Benjaminsen, T., \& Lund, C. (2002). Formalisation and Informalisation of land and water rights in Africa: An introduction. The European Journal of Development Research, 14(2), 1-10. https://doi.org/10.1080/714000420.

Benneh, G. (1968). Types of farm labour in Northern Ghana. Research Review, 4(1), 28-34.

Benneh, G. (1996). Institutional issues on the environment and resource management with reference to Ghana. Retrieved from http://archive.unu.edu/unupress/unupbooks/80918e/80918E0z.htm.

Bequaert, J. C. (1921). Insects as food: How they have augmented the food supply of mankind in early and recent times. Natural History Journal, 21: 191-200.

Berry, S. (1989). Social institutions and access to resources. Africa, 59(1), 41-55. doi:10.2307/1160762.

Berry, S. (1992). Hegemony on a shoestring: Indirect rule and access to agricultural land. Africa, 62(3), 327-355. doi:10.2307/1159747.

Berry, S. S. (1993). No condition is permanent: The social dynamics of agrarian change in sub-Saharan Africa. Madison, Wis.: University of Wisconsin Press.

Berry, S. (2001). Chiefs know their boundaries: Essays on property, power, and the past in Asante, 1896-1996. Portsmouth, NH: Heinemann.

Berry, S. (2013). Questions of ownerships: Proprietorship and control in a changing rural terrain - A case study from Ghana. Africa, 83(01), 36-56. https://doi.org/10.1017/S0001972012000708.

Besley, T. (1995). Property rights and investment incentives: Theory and evidence from Ghana. Journal of Political Economy, 103(5), 903-937.

Bevir, M. (1999). Foucault, power, and institutions. Political Studies, 47(2), 345-359.

Bierschenk, T., \& de Sardan, J. P. O. (2003). Powers in the village: Rural Benin between democratisation and decentralisation. Africa, 73(2), 145-173.

Blaikie, P. (2016). The political economy of soil erosion in developing countries. London: Longman.

Blaikie, P. (1995). Changing environments or changing views? A political ecology for developing countries. Geography, 80(3), 203-214. Retrieved from http://www.jstor.org/stable/40572665.

Blench, R., \& Dendo, M. (2007). Working paper: Agricultural production and the potential for commodity chain expansion in the three northern regions of Ghana in 2006. Retrieved from 
http://www.rogerblench.info/Development/Ghana/FAO/Blench\%20Working\%20Paper\%20Ghana\%202006\%20revised.pdf.

Blench, R.M. (1999). Agriculture and the environment in northeastern Ghana: A comparison of high and medium population density areas. In R. M. Blench (Ed.), Natural resource management and socio-economic factors in Ghana (pp. 21-43). London: Overseas Development Institute.

Blocher, J. (2006). Building on custom: Land tenure policy and economic development in Ghana. Yale Human Rights and Development Law Journal, 9(1), 167-202.

Blundo, G., \& Le Meur, P.-Y. (2009). Introduction: An anthropology of everyday governance: Collective service delivery and subject-making. In G. Blundo \& P.-Y. Le Meur (Eds.), The governance of daily life in Africa. Ethnographic explorations of public and collective services (v. 19, pp. 138). Leiden, Boston: Brill.

Boahen, A. A. (1975). Ghana: Evolution and change in the nineteenth and twentieth centuries: Evolution and change in the nineteenth and twentieth centuries. London: Longman.

Boamah, N. A. (2013). Urban land market in Ghana: A study of the Wa Municipality. Urban Forum, 24(1), 105-118. https://doi.org/10.1007/s12132-013-9187-z.

Bon, H., Parrot, L., \& Moustier, P. (2010). Sustainable urban agriculture in developing countries. A review. Agronomy for Sustainable Development, 30(1), 21-32. https://doi.org/10.1051/agro:2008062.

Bose, P., Arts, B., \& van Dijk, H. (2012). 'Forest governmentality': A genealogy of subject-making of forest-dependent 'scheduled tribes' in India. Land Use policy, 29, 664-673. doi: 10.1016/j.landusepol.2011.11.002.

Bourke, B. (2014). Positionality: Reflecting on the research process. The qualitative report, 19(18), 1-9. Retrieved from http://www.nova.edu/ssss/QR/QR19/bourke18.pdf

Bowdich, T. E. (1819). Mission from cape coast to Ashantee. London: J. Murray.

Brasselle, A.-S., Gaspart, F., \& Platteau, J.-P. (2002). Land tenure security and investment incentives: Puzzling evidence from Burkina Faso. Journal of Development Economics, 67(2), 373-418.

Breth, S., \& Dowswell, C. R. (2003). Sasakawa Africa association. Annual report 2002-2003, Tokyo, Japan: Nippon.

Briggs, J., \& Yeboah, lan. E. A. (2001). Structural adjustment and the contemporary sub-Saharan african city. Area, 33(1), 18-26. https://doi.org/10.1111/1475-4762.00004.

Brobbey, S. A. (2008). The law of chieftaincy in Ghana. Accra: Advanced Legal Publications.

Brukum, Nana James Kwaku. (1997). The northern territories of the gold coast under British colonial rule, 1897-1956: A study in political change. PhD thesis. Ottawa: National Library of Canada.

Bryant, R. L. (1998). Power, knowledge and political ecology in the third world: A review. Progress in Physical Geography, 22(1), 74-94. https://doi.org/10.1177/030913339802200104.

Bryman, A. (2012). Social research methods 4e (4th rev ed). Oxford, UK: Oxford University Press. 
Busia, K. A. (1968). The position of the chief in the modern political system of Ashanti (vol 49). London: Oxford University Press; Cass.

Callaway, H. (1992). Ethnography and experience: Gender implications in fieldwork and texts. In J. Okely \& H. Callways (Eds.), Anthropology and Autobiography (pp. 29-49). New York, NY: Routledge.

Callon, M. (1986). Some elements of a sociology of translation: domestication of the scallops and the fishermen of St Brieuc Bay. In J. Law (Ed.), Power, Action, and Belief: A New Sociology of Knowledge? (pp. 196-223). London.: Routledge and kegan Paul books.

Cardinall, A. W., \& Tamakloe, E. F. (1931). Tales told in Togoland and mythical and traditional history of the Dagomba. [London]: Oxford University Press.

Castillo, G. E. (2003). Livelihoods and the city: An overview of the emergence of agriculture in urban spaces. Progress in Development Studies, 3(4), 339-344.

Chagomoka T, Drescher A, Glaser R, Marschner B, Schlesinger J, Nyandoro G. (2015a). Vegetable production, consumption and its contribution to diets along the urban - rural continuum in Northern Ghana. African Journal of Food, Agriculture, Nutrition and Development, 15(4), 10352-10367.

Chagomoka, T., Nchanji, E. B., Bellwood-Howard, I., Schlesinger, J., Schareika, N., Drescher, A. W., \& Glaeser, A. (2015b). Land tenure and its implications for food and nutritional insecurity in the northern Region of Ghana. Submitted to Land Use Policy.

Chauvin, N. D., Mulangu, F., \& Porto, G. (2012). Food production and consumption trends in subSaharan Africa: Prospects for the transformation of the agricultural sector. UNDP Regional Bureau for Africa: New York, NY, USA. Retrieved from https://www.researchgate.net/profile/Francis_Mulangu2/publication/263257182_Food_Production_and_Consumption_Trends_in_Sub-Saharan_Africa_Prospects_for_the_Transformation_of_the_Agricultural_Sector/links/55f1561008aef559dc470917/Food-Production-and-Consumption-Trendsin-Sub-Saharan-Africa-Prospects-for-the-Transformation-of-the-Agricultural-Sector.pdf.

Chouin, G. (2002). Sacred Groves in History. IDS Bulletin, 33(1), 39-46. https://doi.org/10.1111/j.1759-5436.2002.tb00005.x.

Clark, G. (1994). Onions are my husband: Survival and accumulation by West African market women. Chicago: University of Chicago Press. Retrieved from http\%3A//www.worldcat.org/oclc/659561882.

Cobbina, S. J., Anyidoho, L. Y., Nyame, F., \& Hodgson, I O A. (2010). Water quality status of dugouts from five districts in Northern Ghana: implications for sustainable water resources management in a water stressed tropical savannah environment. Environmental monitoring and assessment, 167(1-4), 405-416. https://doi.org/10.1007/s10661-009-1059-6.

Cobbina, S. J., Kotochi, M. C., Korese, J. K., \& Akrong, M. O. (2013). Microbial Contamination in Vegetables at the Farm Gate Due to Irrigation with Wastewater in the Tamale Metropolis of 
Northern Ghana. Journal of Environmental Protection, 4, 676-682. Retrieved from http://dx.doi.org/10.4236/jep.2013.47078.

Cobbina, S. J., Michael, K., Salifu, L., \& Duwiejua, A. B. (2013). Rainwater quality assessment in the Tamale municipality. International Journal of Scientific and Technology Research, 2(5).

Colson, E. (1971). The impact of the colonial period on the definition of land rights. In V. Turner (Ed.), Colonialism in Africa 1870-1960 (pp. 193-215). London: Cambridge University Press.

Colvin, C. J., Robins, S., \& Leavens, J. (2011). Grounding 'responsibilisation talk': Masculinities, citizenship and HIV in Cape Town, South Africa. In S. Hickey (Ed.), The government of chronic poverty. From the politics of exclusion to the politics of citizenship? (pp. 41-57). Abingdon, New York, N.Y.: Routledge.

Coronel Lamas, J. M., \& Rodríguez Pascual, I. (2013). Let me put it another way: Methodological considerations on the use of participatory photography based on an experiment with teenagers in secondary schools. Qualitative Research in Education, 2(2), 98-129. Retrieved from http://dx.doi.org/10.4471/qre.2013.20.

Cotula, L., Hesse, C., Sylla, O., Thébaud, B., Gill, Vogt, \& Vogt, K. (2006). Land and water rights in the Sahel: tenure challenges of improving access to water for agriculture. In L. Cotula (Ed.), Land and water rights in the Sahel: tenure challenges of improving access to water for agriculture (pp. 1-58). IIED. LSP Working Paper 25. Retrieved from http://www.fao.org/3/aah246e.pdf.

Cromwell, E. (1990). Seed diffusion mechanisms in small farmer communities. lessons from Asia, Africa and Latin America. Network paper-agricultural administration (research and extension) network. Agricultural administration unit. Overseas Development Institute, United Kingdom.

Crook, R., Affou, S., Hammond, D., Vanga, A. F., \& Yeboah, M. O. (2007). The law, legal institutions and the protection of land rights in Ghana and Côte d'Ivoire: Developing a more effective and equitable system. IDS Research Report 58, 1-210. Retrieved from https://www.ids.ac.uk/files/Rr58.pdf.

Cyr, J. (2016). The pitfalls and promise of focus groups as a data collection method. Sociological Methods \& Research, 45(2), 231-259. https://doi.org/10.1177/0049124115570065.

Da Rocha, B. J., \& Lodoh, C. H. K. (1999). Land law and conveyancing in Ghana. Accra, Ghana.

Danso, G., Drechsel, P., Obuobei, E., Forkuo, G., \& Kranjac-Berisavljevic, G. (2014). Urban vegetable farming sites, crops and cropping practices. In P. Drechsel \& B. Keraita (Eds.), Irrigated urban vegetable production in Ghana: characteristics, benefits and risk mitigation (2nd ed., pp. 727). Colombo, Sri Lanka: International Water Institute (IWMI).

Danso, G., Drechsel, P., Wiafe-Antwi, T. (2002). Income of Farming Systems around Kumasi. Urban Agriculture Magazine, 7, 5-6. 
Dawson, J. (2002). Empowering Ghana's cereal producers in the market place. In S. Kapila \& D. Mead (Eds.), Building business with small producers: Successful business development services in Africa, Asia and Latin America (pp. 94-120). Ottawa, Canada.

De laine Marlene. (1997). Ethnography: Theory and applications in health research. Sydney, Australia: Maclennan and Petty.

Dean, M. (2010). Governmentality: Power and rule in modern society (2nd ed). London, Thousand Oaks, Calif.: SAGE.

Delafosse, M. (1912). Haut-Sénégal-Niger (Soudan français). Paris, Larose.

Derman, B., \& Hellum, A. (2007). Land, identity and violence in Zimbabwe. In W. Derman, R. Odgaard, \& E. Sjaastad (Eds.), Conflicts over land \& water in Africa (pp. 161-186). Oxford: James Currey.

Dezalay, Y., \& Garth, B. (1995). Merchants of law as moral entrepreneurs: Constructing international justice from the competition for transnational business disputes. Law and Society Review, 29(1), 27. https://doi.org/10.2307/3054053.

Dicicco-Bloom, B., \& Crabtree, B. F. (2006). The qualitative research interview. Medical education, 40(4), 314-321. https://doi.org/10.1111/j.1365-2929.2006.02418.x.

Dickson, K. B. (1968). Background to the problem of economic development in northern Ghana. Annals of the Association of American Geographers, 58(4), 686-696. https://doi.org/10.1111/j.1467-8306.1968.tb01662.x.

Dickson, K. B. (1969). The Historical geography of Ghana. London: Cambridge University Press.

Drechsel, P., \& Dongus, S. (2010). Dynamics and sustainability of urban agriculture: examples from sub-Saharan Africa. Sustainability Science, 5(1), 69-78. https://doi.org/10.1007/s11625-0090097-x.

Drechsel, P., Graefe, S., Sonou, M., \& Cofie, O. (2006). Informal irrigation in urban west Africa: An overview. International Water Management Institute, Colombo, IWMI Research Report 102. Retrieved from http://www.worldagroforestry.org/treesandmarkets/hvc07_meet/other_materials/IWMI\%20Urban\%20Irrigation\%20West\%20Africa.pdf.

Drescher, A. W., \& laquinta, D. (2002). Urbanization - linking development across the changing landscape. Rome, Italy, FAO. Retrieved from www.fao.org/fileadmin/templates/FCIT/PDF/sofa.pdf.

Dubbeling, M. (2013). Urban and peri-urban agriculture as a means to advance disaster risk reduction and adaptation to climate change. Regional Development Dialogue, 34(1), 134-149.

Eguavoen, I. (2008). The political ecology of household water in Northern Ghana (Vol. 10). LIT Verlag Münster.

Elmhirst, R. (2011). Migrant pathways to resource access in Lampung's political forest: Gender, citizenship and creative conjugality. Geoforum, 42(2), 173-183. https://doi.org/10.1016/j.geoforum.2010.12.004. 
Embree, L. (2015). The schutzian theory of the cultural sciences (Vol. 78). Cham: Springer International Publishing.

Erfurt, M. (2014). Landnutzungswandel in Tamale, Nord Ghana. Unpublished bachelor thesis. Albert Ludwigs University, Freiburg.

Escobar, A. (1999). After nature: Steps to an antiessentialist political ecology. Current Anthropology, 4O(1), 1-30. https://doi.org/10.1086/515799.

Etwire, P. M., Atokple, I. D., Buah, S. S., Abdulai, A. L., Karikari, A. S., \& Asungre, P. (2013). Analysis of the seed system in Ghana. International Journal of Advance Agricultural Research, 1(1), 713.

Fage, J. D. (1956). Some notes on a scheme for the investigation of oral tradition in the northern Territories of the Gold Coast. Journal of the Historical Society of Nigeria, 1(1), 15-19. Retrieved from http://www.jstor.org/stable/41856609.

Fage, John D. "Reflections on the early history of the Mossi-Dagomba group of states." In J. Vansina, R. Mauny and L. V. Thomas (eds.), The historian in tropical Africa (pp. 177-192). Routledge, 2018.

Falkenmark, M. (1989). The massive water scarcity now threatening Africa- Why isn't it being addressed? Ambio, 18(2), 112-118.

FAO. (1995). Irrigation potentials for Africa: A basin approach: Land and water development division, FAO, Rome. Retrieved from http://www.fao.org/docrep/W4347E/W4347E00.htm.

Farnsworth, J., \& Boon, B. (2010). Analysing group dynamics within the focus group. Qualitative Research, 10(5), 605-624. https://doi.org/10.1177/1468794110375223.

Ferguson, J., \& Gupta, A. (2002). Spatializing states: Toward an ethnography of neoliberal governmentality. American Ethnologist, 29(4), 981-1002. Retrieved from http://www.jstor.org/stable/3805165.

Firmin-Sellers, K. (1996). The transformation of property rights in the Gold Coast. New York: Cambridge University Press.

Fortes, M., \& Fortes, S. L. (1936). Food in the domestic economy of the Tallensi. Africa, 9(02), 237276. https://doi.org/10.2307/1155627.

Fortmann, L. (1995). Talking claims: Discursive strategies in contesting property. World Development, 23(6), 1053-1063. https://doi.org/10.1016/0305-750X(95)00024-7.

Foucault, M. (1978). The history of sexuality (Vol. 1). New York: Pantheon Books.

Foucault, M. (1982). The subject and power. Critical Inquiry, 8(4), 777-795. Retrieved from http://www.jstor.org/stable/1343197

Foucault, M. (1991). Governmentality. In M. Foucault, G. Burchell, C. Gordon, \& P. Miller (Eds.), The foucault effect. Studies in governmentality: with two lectures by and an interview with Michel Foucault (pp. 87-104). Chicago: University of Chicago Press. 
Foucault, M. (2001). Governmentality. In J. D. Faubion (Ed.), Power: Essential works of foucault, 1954-1984 (pp. 201-222). New York: New Press.

Foucault, M. (2006). Governmentality. In A. Sharma \& A. Gupta (Eds.), Blackwell readers in anthropology: Vol. 9. The anthropology of the state. A reader (pp. 131-143). Malden, MA, Oxford: Blackwell Pub.

Foucault, M. (2007). Security, territory, population: Lectures at the collège de France, 1977-78. Basingstoke, New York: Palgrave MacMillan; République Française.

Froelich, J. C. (1954). La tribu Komkomba du Nord Togo: IFAN-Dakar.

Fuseini, I., \& Kemp, J. (2015). A review of spatial planning in Ghana's socio-economic development trajectory: A sustainable development perspective. Land Use Policy, 47, 309-320. https://doi.org/10.1016/j.landusepol.2015.04.020.

Fynn, J. K. (1971). Asante and its neighbours, 1700-1807. [Harlow], [Evanston, III.]: Longman; Northwestern University Press.

Galhena, D., Freed, R., \& Maredia, K. M. (2013). Home gardens: a promising approach to enhance household food security and wellbeing. Agriculture \& Food Security, 2(1), 8. https://doi.org/10.1186/2048-7010-2-8.

Gall, M. D., Gall, J. P., \& Borg, W. R. (2003). Educational research : An introduction (7th ed). Boston: Allyn and Bacon.

Geest, Kees van der. (2004). We're managing! climate change and livelihood vulnerability in Northwest Ghana. Research report / African studies centre: 74/2004. Leiden. Retrieved from http\%3A/www.worldcat.org/oclc/56767486

Ghana Statistical Service (2005). '2000 Population and Housing Census, Population Data Analysis Reports, vol. 1: Socio-economic and Demographic Trends Analysis'. Accra: Ghana Statistical Service.

Ghana Statistical Service. (2013). 2010 Population and housing Census: Regional Analytical report, Northern Region. Retrieved from http://www.statsghana.gov.gh/docfiles/2010phc/2010_PHC_Regional_Analytical_Reports_Northern_Region.pdf.

Ghana Statistical Service. (2014). Population and Housing Census: District Analytical Report, Tamale Metropolis. Retrieved from http://www.statsghana.gov.gh/docfiles/2010_District_Report/Northern/Tamale\%20Metropolitan.pdf.

Ghani, A. (1995). Production and Reproduction of Property as a Bundle of Powers: Afghanistan 17741901: Draft discussion paper in Agrarian Studies Program. New Haven: Yale University.

Gichuki, F., Mbogoh, S., Tiffen, M., \& Mortimore, M. (2000). Makueni district profile: Rainfall variability, 1950-1997. Dryland Research Working Paper No. 2. Somerset, Drylands Research, England. 
Retrieved from http://citeseerx.ist.psu.edu/viewdoc/download;jsessionid=8F15A39F415D017CDFFF02EE35F9CFDD?doi=10.1.1.498.6949\&rep=rep1\&type=p df.

Girdner, J., Olorunsola, V., Froning, M., \& Hansen, E. (1980). Ghana's agricultural food policy. Food Policy, 5(1), 14-25. https://doi.org/10.1016/0306-9192(80)90021-4.

Giweta, Mekonnen, H. (2011). Mainstreaming wastewater management in urban planning: A case study of Tamale metropolis, Ghana (master thesis). Wageningen University and Montpellier Sup Agro/IRC., Netherlands and France.

Gluckman, M. (1940). Analysis of a socisl situation in modern Zululand. Bantu Studies, 14(1), 1-30. https://doi.org/10.1080/02561751.1940.9676107.

Gockowski, J., Mbazo'o, J., Mbah, G., \& Fouda Moulende, T. (2003). African traditional leafy vegetables and the urban and peri-urban poor. Food Policy, 28(3), 221-235. https://doi.org/10.1016/S0306-9192(03)00029-0.

Godfray, H Charles J, Beddington, J. R., Crute, I. R., Haddad, L., Lawrence, D., Muir, J. F.,. . Toulmin, C. (2010). Food security: the challenge of feeding 9 billion people. Science, 327(5967), 812-818. https://doi.org/10.1126/science.1185383.

Golafshani, N. 2. (2003). Understanding reliability and validity in qualitative research. The Qualitative Report, 8(4), 594-607. Retrieved from http://www.nova.edu/ssss/QR/QR8-4/golafshani.pdf.

Goody, J., \& Buckley, J. (1973). Inheritance and Women's Labour in Africa. Africa, 43(02), 108-121. https://doi.org/10.2307/1159323

Gordon, C. (1991). Governmental rationality. In M. Foucault, G. Burchell, C. Gordon, \& P. Miller (Eds.), The foucault effect. Studies in governmentality: with two lectures by and an interview with Michel Foucault (pp. 1-52). Chicago: University of Chicago Press.

Grey, T. C. (1980). The disintegration of property. In J.R. Pennock and J.W. Chapman (eds.) Nomos XXII: Property. (pp. 69-85). New York: New York University Press.

Grischow, J. (2006). Shaping tradition: Civil society, community and development in colonial northern Ghana 1899-1957. Leiden, Netherlands: Brill Academic.

Guba, E., \& Lincoln, Y. (1989). Fourth generation evaluation. Newbury Park, CA: SAGE.

Gyan, K. (2005). Article 267(5) of the 1992 constitution and the death of the freehold interest in stool lands in Ghana: Unpublished paper from the Ministry of Lands, Forestry and Mines. Rerieved from https://www.linkedin.com/pulse/further-defense-martyrs-customary-freehold-interest-under-fynn/.

Gyasi, E. A., Fosu, M., Kranjac-Berisavljevic, G., Mensah, A. M., Obeng, F., Yiran, G.A.B., \& Fuseini, I. (2014). Building urban resilience: Assessing urban and peri-urban agriculture in Tamale, Ghana. [Padgham, J. and J. Jabbour (eds.)]. Nairobi, Kenya: United Nations Environment Programme (UNEP). 
Gyasi, E. A., Kranjac-Berisavljevic, G., Fosu, M., Mensah, A. M., Yiran, G., \& Fuseini, I. (2014). Managing threats and opportunities of urbanisation for urban and peri-urban agriculture in Tamale, Ghana. The Security of Water, Food, Energy and Liveability of Cities, 71, 87-97. https://doi.org/10.1007/978-94-017-8878-6_7.

Hagberg, S. (2006). The transformation of ritual boundaries in resource-use practices in Burkina Faso. Africa Today, 52(4), 109-129. https://doi.org/10.1353/at.2006.0046.

Hailey, L. (1956). An African Survey. London: Oxford University Press.

Hann, C. (1998). Introduction: the embeddedness of property. In C. M. Hann (Ed.), Property relations: renewing the anthropological tradition. (pp. 1-47). Cambridge, New York: Cambridge University Press.

Hayes, R., \& Oppenheim, R. (1997). Constructivism: Reality is what you make it. In T. Sexton \& B. Griffin (Eds.), Constructivist thinking in counseling practice, research and training (pp. 19-41). New York: Teachers College Press.

Heidhues, F., \& Obare, G. (2011). Lessons from structural adjustment programmes and their effects in Africa. Quarterly Journal of International Agriculture, 50(1), 55-64.

Heidhues, F., Atsain, A., Nyangito, H., Padilla, M., Ghersi, G., \& Le Vallee, J.C. (2004). Development strategies and food and nutrition security in Africa: An sssessement 2020. Discussion Paper No. 38. IFPRI, Washington D.C. Rerieved from http://ageconsearch.umn.edu/bitstream/42270/2/2020dp38.pdf.

Hirschman, A. O. (1958). The strategy of economic development (Vol. 40). New Haven CT: Yale University Press.

Hollander, J. A. (2004). The social contexts of focus groups. Journal of Contemporary Ethnography, 33(5), 602-637. https://doi.org/10.1177/0891241604266988.

Howard, R. (1978). Colonialism and underdevelopment in Ghana. London: Croom Helm.

Hughes, K. A., Knox, a., \& Jones-Casey, K. (2011). Customary leaders and conflicts of interest over land in Ghana. Brief - Focus on land in Africa, 1-5. Retrieved from www.focusonland.com

Hughes, T. (2003). Managing group grievances and internal conflict: Ghana country report, Working paper series: Netherlands Institute of International Relations'Clingendael'. Conflict research unit. Working Paper 11. Retrieved from http://docplayer.net/39072707-Working-paper-seriesworking-paper-11-managing-group-grievances-and-internal-conflict-ghana-country-reporttim-hughes.html.

Hume, L., \& Mulcock, J. (2004). Anthropologists in the field: Cases in participant observation. New York N.Y., Chichester: Columbia University Press.

Iliasu, A. A. (1971). The origins of the Mossi-Dagomba states: University of Ghana at Legon. Research Review, 95-113.

Illenu, N. A. (1962). Principles of customary land law. London: Sweet and Maxwell. 
Imam, H. A. (2015a). State and non-state actors in land appropriation: Colonial land policy and the role of the Tindana in Northern Ghana. Research on Humanities and Social Sciences, 5(4), 126-140.

Imam, H. A. (2015b). Change and cultural survival in Dagbon: Assessing the influence of Islam on aspects of dagbamba cutural practices. International Journal of innovative research and Advanced studies, 2(9), 28-37.

Inda, J. X. (2005). Anthropologies of modernity: Foucault, governmentality, and life politics. Malden, MA: Blackwell Pub.

Ingold, T. (1986). The Appropriation of Nature: Essays on human ecology and social relations. Manchester: Manchester University Press.

International Monetary Fund. (2015). Article iv consultation-press release; Staff report and statement by the executive director for Cameroon. IMF Country Report, 331(15), 1-79. Retrieved from https://www.imf.org/external/pubs/cat/longres.aspx?sk=43433.0.

Jaffee, S., \& Srivastava, J. (1992). Seed system development: The appropriate roles of the private and public sectors. World Bank discussion papers no. WDP 167. Washington, DC: The World Bank. (Vol. 167). Washington, D.C.: World Bank. Retrieved from http://documents.worldbank.org/curated/en/663561468740989528/Seed-system-development-the-appropriate-roles-of-the-private-and-public-sectors.

Janowicz, C. (2008). The world goes urban: Food supply systems and urbanization processes in Africa. In D. Hummel (Ed.), Population dynamics and supply systems. A transdisciplinary approach (pp. 129-160). Frankfurt: Campus Verlag.

Jessop, B. (1977). Recent theories of the capitalist state. Cambridge Journal of Economics, 1(4), 353373. Retrieved from http://www.jstor.org/stable/23596382.

Johnson, B. R. (1997). Examining the validity structure of qualitative research. Education, 118(3), 282-292.

Jonge, B. de, \& Munyi, P. (2016). A differentiated approach to plant variety protection in Africa. The Journal of World Intellectual Property, 19(1-2), 28-52. https://doi.org/10.1111/jwip.12053.

Juul, K., \& Lund, C. (2002). Negotiating property in Africa. Portsmouth, NH: Heinemann.

Karikari, I. B. (2006). Ghana's land administration project (LAP) and land information system (LIS) implimentation: The issues.: 5th International Federation of Surveyors in Africa, Accra, Ghana. Retrieved from https://www.fig.net/resources/monthly_articles/2006/february_2006/karikari_february_2006.pdf.

Kasanga, K. (2001). Land administration reforms and social differentiation: A case study of Ghana's lands commission. IDS Bulletin, 32(1), 57-64.

Kasanga, K. (2002). Land tenure, resource access and decentralisation in Ghana. In C. Toulmin, P. L. Delville, \& S. Traoré (Eds.), The dynamics of resource tenure in West Africa (pp. 25-36). Oxford: James Currey Ltd. 
Kasanga, K. (2003). Current land policy issues in Ghana. In P. Gropo (Ed.), Land reform, land settlement and cooperatives (pp. 141-154). FAO, Rome.

Kasanga, K. R. (1995). Land tenure and regional investment prospects: the case of the tenurial systems of Northern Ghana. Property Management, 13(2), 21-31.

Kasanga, K., \& Kotey, N. A. (2001). Land management in Ghana: Building on tradition and modernity. Retrieved from International Institute for Environment and Development, London. http://pubs.iied.org/pdfs/9002IIED.pdf?pagewanted=all\&sa=U\&ei=_oVZU538AqTh4wSgt/HwAQ\&ved=0CEcQFjAI\&usg=AFQjCNHdUllyYPOPQpEDPOLSCQqdhrOI7Q.

Kherallah, M., Delgado, C., Gabri-Madhin, E., Minot, N., \& Johnson. (2000). The Road half travelled: Agricultural markets reform in sub-Saharan Africa: Food Policy Report No. 10. Washington D. C. Retrieved from http://ebrary.ifpri.org/cdm/ref/collection/p15738coll5/id/2995.

Kimble, D. (1963). A political history of Ghana: the rise of Gold Coast nationalism, 1850-1928. London: Oxford at the Clarendon Press.

Kingston-Mann, E. (2006). The return of Pierre Proudhon: Property rights, crime, and the rules of law. Focaal, 2006(48), 118-127. https://doi.org/10.3167/092012906780646406.

Kludze, A. K. P. (1987). Accountability of the head of family in Ghana: A statutory solution in search of a problem. Journal of African Law, 31(1/2), 107-18.

Kludze, A. K. P. (2000). Chieftaincy in Ghana: Lanham: Austin and Winfield.

Koning, N. (2002). Should Africa protect its farmers to revitalize its econmy? Sustainable agriculture and rural livelihood program. International Institute for Environment and Development. London. Gate Keepers Series no. 105.

Koning, P. (1986). The state and rural class formation in Ghana. London, UK: Routledge and kegan Paul books.

Konings, P. (1984). Capitalist rice farming and land allocation in Northern Ghana. The Journal of Legal Pluralism and Unofficial Law, 16(22), 89-119. https://doi.org/10.1080/07329113.1984.10756284.

Kotey, N. A., Dowuona-Hammond, C., \& Atuguba, R. A. (2004). Ghana land administration project legislative and judicial review. Draft final report. Accra. Kotey and Associates.

Kranjac-Berisavljevic, G., \& Gandaa, B. Z. (2004). Sustaining diversity of yams in northern Ghana. In E. A. Gyasi, G. Kranjac-Berisavljevic, E. T. Blay, \& W. Oduro (Eds.), Managing agrodiversity the traditional way. Lessons from West Africa in sustainable use of biodiversity and related natural resources (pp. 84-96). New York: United Nations University Press.

Kunbour, B. (2002). Customary law of the Dagara of Northern Ghana: Indigenous rules or a social construction. Journal of Dagaare Studies, 2, 1-21. 
Kuusaana, E. D., Kidido, J. K., \& Halidu-Adam, E. (2013). Customary land ownership and gender disparity-evidence from the Wa municipality of Ghana. Ghana Journal of Development Studies, 10(1- 2), 63-80.

La Anyane, S., 1963. Vegetable gardening in Accra. The Ghana farmer, 1 (6), 228-230.

Ladouceur, P. A. (1979). Chiefs and Politicians: the politics of regionalism in northern Ghana. London: Longman.

Lahouel, B. (2011). British Land Legislation in the Gold Coast (1876-1897): A threat to native institutions? In A. Geoffroy (Ed.), Straddled orders (pp. 124-139). France: Faculté des lettres et des sciences humaines de l'université de la réunion.

Larbi, W. O. (2008). Compulsory Land Acquisition and Compensation in Ghana: Searching for Alternative Policies and Strategies: FIG/FAO/CNG International Seminar on State and Public Sector Land Management Verona, Italy, 1-21. Retrieved from https://www.fig.net/resources/proceedings/2008/verona_fao_2008_comm7/papers/09_sept/4_1_larbi.pdf.

Laryea-Adjei, George Quaye Mensah. (2007). Decentralization plus pluralism for basic services provision: Water and sanitation in Ghana. Delft: Eburon.

Latour, B. (1984). The powers of association. The Sociological Review, 32, 264-280. https://doi.org/10.1111/j.1467-954X.1984.tb00115.x

Law, J. (1986). On power and its tactics: A view from the sociology of science. Sociological Review, 34(1), 1-34. https://doi.org/10.1111/j.1467-954X.1986.tb02693.x.

Leathers, H. D., \& Foster, P. (2009). The world food problem: Toward ending undernutrition in the third world (4th ed). Boulder: Lynne Rienner Publishers.

Leegwater, M. (2011). Sharing scarcity: Issues of land tenure in south-east Rwanda. In A. Ansoms \& S. Marysse (Eds.), Natural resources and local livelihoods in the Great Lakes region of Africa: A political economypPerspective (pp. 104-122). Basingstoke: Palgrave Macmillan.

Lee-Smith, D. (2010). Cities feeding people: an update on urban agriculture in equatorial Africa. Environment and Urbanization, 22(2), 483-499. https://doi.org/10.1177/0956247810377383.

Lele, U., Pretty, J., Terry, E., \& Trigo, E. (2010). Transforming agricultural research for development. report for the global conference on agricultural research. Montpeiller, France. Retrieved from http://www.fao.org/docs/eims/upload/316093/GAT_Report_GCARD_2010.pdf.

Lemke, T. (2000). Foucault, governmentality, and critique: Paper presented at the rethinking marxism conference, University of Amherst. Retrieved from http://www.thomaslemkeweb.de/publikationen/Foucault,\%20Governmentality,\%20and\%20Critique\%20IV-2.pdf.

Lentz, C. (1998). The Chief, the mine captain and the politician: Legitimating power in Northern Ghana. Africa: Journal of the International African Institute, 68(1), 46. https://doi.org/10.2307/1161147.

Lentz, C. (2013). Land, mobility, and belonging in West Africa. Bloomington, IN: Indiana University Press. 
Li, T. M. (2007a). The will to improve: governmentality, development, and the practice of politics: Duke University Press.

Li, T. M. (2007b). Governmentality. Anthropologica, 49(2), 275-281.

Liamputtong, P. (2011). Focus group methodology: Principles and practices. Los Angeles: SAGE.

Lincoln, Y. S., \& Guba, E. G. (1985). Naturalistic inquiry. Beverly Hills, CA: SAGE.

Lipton, M., \& Ahmed, I. (1997). Impact of structural adjustment on sustainable rural livelihoods: A review of the literature. IDS Working Paper 62, 1-33. Retrieved from http://mobile.opendocs.ids.ac.uk/opendocs/bitstream/handle/123456789/3366/Wp62.pdf?sequence=1 .

Lipton, M., Litchfield, J., Blackman, R., De Zoysa, D., Qureshy, L., \& Waddington, H. (2003). The impact of irrigation on poverty. Poverty Research Unit at Sussex, University of Sussex, UK.

Louwaars, N. P., \& de Boef, Walter Simon. (2012). Integrated seed sector development in Africa: A conceptual framework for creating coherence between practices, programs, and policies. Journal of Crop Improvement, 26(1), 39-59. https://doi.org/10.1080/15427528.2011.611277.

Lund, C. (2014). Tinkering methodology-some considerations concerning the study of access to and control over natural resources. Occasional Paper, (13), 11-23. Roskilde Universitets Forlag, Denmark.

Lund, C. (1998). Struggles for land and political power. The Journal of Legal Pluralism and Unofficial Law, 30(40), 1-22. https://doi.org/10.1080/07329113.1998.10756496.

Lund, C. (2002). Negotiating property institutions: On the symbiosis of property and authority in Africa. In K. Juul \& C. Lund (Eds.), Negotiating property in Africa (pp. 11-43). Portsmouth, UK: Heinemann.

Lund, C. (2006). Twilight institutions: Public authority and local politics in Africa. Development and Change, 37(4), 685-705.

Lund, C. (2008a). Local politics and the dynamics of property in Africa. New York: Cambridge University Press.

Lund, C. (2008b). Who Owns Bolgatanga? The revival of the earthpriest and emerging tensions over property. In C. Lund (Ed.), Local politics and the dynamics of property in Africa (pp. 47-67). Cambridge: Cambridge University Press. https://doi.org/10.1017/CBO9780511510564.005.

Lund, C., \& Boone, C. (2013). Introduction: Land politics in Africa-Constituting authority over territory, property and persons. Africa, 83(01), 1-13. https://doi.org/10.1017/s000197201200068X.

Luttrell, W., \& Chalfen, R. (2010). Lifting up voices of participatory visual research. Visual Studies, 25(3), 197-200. https://doi.org/10.1080/1472586X.2010.523270.

Lwasa, S., \& Dubbeling, M. (2015). Urban agriculture and climate change. In H. d. Zeeuw \& P. Drechsel (Eds.), Cities and agriculture. Developing resilient urban food systems (pp. 193-217). New York: Routledge. 
Lwasa, S., Mugagga, F., Wahab, B., Simon, D., Connors, J., \& Griffith, C. (2014). Urban and periurban agriculture and forestry: Transcending poverty alleviation to climate change mitigation and adaptation. Urban Climate, 7, 92-106. https://doi.org/10.1016/j.uclim.2013.10.007.

Lynn, C. (1942). Agriculture in North Mamprusi: A review of a decade's progress. Farm and Forest, 3, 78-83.

MacGaffey, W. (2006). Death of a king, death of a kingdom? Social pluralism and succession to high office in Dagbon, Northern Ghana. The Journal of Modern African Studies, 44(01), 79. https://doi.org/10.1017/S0022278X05001424.

Macpherson, C. B. (1978). Property. In C. B. Macpherson (Ed.), Property, mainstream and critical positions (pp. 1-14). Toronto: University of Toronto Press.

Mahama, A. (2015). New Energy assists four small-holder farmer associations in the Northern Region of Ghana with solar powered irrigation schemes. Ghana-SE4ALL News, 4. Retrieved from http://energycom.gov.gh/files/Ghana-SE4ALL-newsletter\%20_Jan-Jun-15.pdf

Mahama, I. (2003). Ethnic conflicts in Northern Ghana, Tamale: Cyber Systems.

Mahama, I. (2009). A colonial history of Northern Ghana. Tamale: GILLBT Printing Press.

Maine, H. (1861). Ancient Law. London: J Murray.

Manji, A. (2003). Capital, labour and land relations in Africa: A gender analysis of the world bank policy research report on land institution and land policy. Third Quarterly, 24(1), 97-114.

Maplecrof. (2013). Water stress index. Retrieved from https://www.maplecroft.com/about/news/water-stress.html.

Marshall, M. N. (1996). The key informant technique. Family Practice, 13(1), 92-97.

Maxwell, J. A. (1996). Qualitative research design: An interactive approach (v. 41). Thousand Oaks, Calif.: Sage Publications.

Mbaye, A., \& Moustier, P. (2000). Market-oriented urban agricultural production in Dakar. In N. Bakker, M. Dubbeling, S. Guendel, U. Sabel Koschella \& H. de Zeeuw (Eds.), Growing cities, growing food: Urban agriculture on the policy agenda (pp. 235-256). DSE. Retrieved from https://www.ruaf.org/publications/growing-cities-growing-food-urban-agriculture-policyagenda.

McCann, J. C. (2011). The Political ecology of cereal seed development in Africa: A history of Selection. IDS Bulletin, 42(4), 24-35. https://doi.org/10.1111/j.1759-5436.2011.00233.x.

McCaskie, T. (1980). Office land and subjects in the history of the manwere fekou of Kumase: An essay in the political economy of the Asante state. The Journal of African History, 21(02), 189208. https://doi.org/10.1017/s0021853700018168.

McCaskie, T.C. (1984). Ahyiamu - 'A place of meeting': An essay on process and event in the history of the Asante state. The Journal of African History, 25(02), 169-188. https://doi.org/10.1017/s0021853700022842.

McIntyre, B. D. (2009). Global report. Washington, DC: Island Press. 
Meadows, L. M., Lagendyk, L. E., Thurston, W. E., \& Eisener, A. C. (2003). Balancing culture, ethics and methods in qualitative health research with aboriginal peoples. International Journal of Qualitative Methods, 2(4), 1-14. https://doi.org/10.1177/160940690300200401.

Meinzen-Dick, R., \& Pradhan, R. (2002). Legal pluralism and dynamic property rights: CGIAR systemwide program on collective action and property rights. Working paper nos 22 . Retrieved from https://ageconsearch.umn.edu/bitstream/55442/2/capriwp22.pdf.

Mensah, K. B. (1999). Water law, water rights and water supply (Africa). Ghana-study country report. Silsoe, department for international development, 28. Retrieved from https://assets.publishing.service.gov.uk/media/57a08d9840f0b64974001950/R73272.pdf.

Mends, T. M. (2006). Customary land tenure and urbanization with a case study on the peri-urban area of Accra, Ghana (Masters thesis). University of Twente, Enschede.

Merlingen, M. (2006). Foucault and world politics: Promises and challenges of extending governmentality theory to the european and beyond. Millennium - Journal of International Studies, 35(181), 181-196. Retrieved from http://mil.sagepub.com/cgi/reprint/35/1/181.

Merry, S. (1988). Legal pluralism. Law \& Society Review, 22(5), 869-896. doi:10.2307/3053638.

Migot-Adhola S E. (1994). Land security of tenure and productivity in Ghana. In J. W. Bruce \& MigotAdhola S E (Eds.), Searching for land tenure security in Africa (pp. 97-118). Dubuque, Cy, IA: Kendall and Hunt.

Miller, T. \& Bell, L. (2002). Consenting to what? Issues of access, gate-keeping and informed consent. In M. Mauthner, M. Birch, J. Jessop, \& T. Miller (Eds.), Ethics in qualitative research (pp. 5467). London: Sage Publications.

Miller, T., \& Boulton, M. (2007). Changing construction of informed consent: Qualitatve research and complex social worlds. Social Science and Medicine, 65, 2199-2211.

Mills, J., Bonner, A., \& Francis, K. (2006). The development of constructivist grounded theory. International Journal of Qualitative Methods, 5(1). Retrieved from http://www.ualberta.ca/ iiqm/backissues/5_1/pdf/mills.pdf.

Ministry of Food and Agriculture. (2011). National irrigation policy, strategies, and regulatory measures. Accra, Ghana: Ghana irrigation development authority, Ghana. Retrieved from http://mofa.gov.gh/site/wp-content/uploads/2011/07/GHANA-IRRIGATION-DEVELOPMENTPOLICY1.pdf.

Ministry of Land and Forestry. (2003a). Emerging land tenure Issues.Accra. Ghana.

Ministry of Land and Forestry. (2003b). Implementation manual for land administration project (LAP1) (2003-2008). Accra. Ghana.

Ministry of Lands and Forestry. (1999). National Land Policy. Accra. Ghana

Mitchell, J. C. (2006). Case and situational analysis. In T. M.S. Evens \& D. Handelman (Eds.), Practice and ethnographic praxis in anthropology (1st ed., pp. 23-42). Manchester: Berghahn Books. 
Moore, S. F. (1989). History and the redefinition of custom on Kilimanjaro. In J. Starr \& J.F. Collier (Eds.), History and power in the study of law: New directions in legal anthropology (pp. 277301). Ithaca: Cornell University Press.

Moore, S. F. (1998). Changing african land tenure: Reflections on the incapacities of the state. Journal of Development Research, 33-48.

Moravcsik, A. (2014). Transparency: The revolution in qualitative research. Political Science \& Politics, 47(01), 48-53. https://doi.org/10.1017/S1049096513001789.

Morgan, D. L. (1996). Focus groups. Annual Review of Sociology, 22(1), 129-152. https://doi.org/10.1146/annurev.soc.22.1.129.

Morse, J. M. (2015). "Data were saturated... ". Qualitative health research, 25(5), 587-588. https://doi.org/10.1177/1049732315576699.

Morse, J. M., Barrett, M., Mayan, M., Olson, K., \& Spiers, J. (2002). Verification strategies for establishing reliability and validity in qualitative research. International Journal of Qualitative Methods, 1(2). Retrieved from http://www.ualberta.ca/ ijqm/.

Mougeot, L. J. A. (1995). L'agriculture urbain en Afrique d'un point de vue mondial. In Egziabher, A. G., Lee-Smith, D., Maxwell, D. G., Memon, P. A., Mougeot, L. J., \& Sawio, C. J. (EDS.), Faire campagne en ville: l'agriculture urbaine en Afrique de l'Est (pp.1-30). CRDI, Ottawa.

Mougeot, L. J. A. (2000). Urban agriculture: definition, presence, potentials and risks. In N. Bakker, M. Dubbeling, S. Guendel, U. Sabel Koschella \& H. de Zeeuw (Eds.), Growing cities, growing food: Urban agriculture on the policy agenda (pp. 1-42). DSE. Retrieved from https://www.ruaf.org/publications/growing-cities-growing-food-urban-agriculture-policyagenda.

Mougeot, L.J.A. (1994). Urban food production: evolution, official support and significance. Cities feeding people report 8. International development research centre Ottawa, Canada. Retrieved from https://idl-bnc-idrc.dspacedirect.org/bitstream/handle/10625/14949/103013.pdf?sequence=1.

Moustier, P. (2001). Assessing the socio-economic impact of urban and peri-urban agricultural development. Paper submitted to the workshop on appropriate methodology in urban agriculture research, planning, implementation and evaluation, Nairobi, Kenya, organized by CIP-SUIPA and ETC-RUAF. Urban Agriculture Magazine, 5, 47-48. Retrieved from http://www.ruaf.org/ conferences_fr.html.

Moustier, P., \& Fall, A. (2004). Les dynamique de l'agriculture urbaine: caractèraction et évaluation. In Olanrewuju, B Smith; Moustier, P; Mougeot, A; Fall, S (Eds.), Développement durable de l'agriculture urbaine en Afrique francophone: enjeux, concepts et méthodes (pp. 23-43). Montpellier: CIRAD. 
Murphy, H., \& Kellow, A. (2013). Forum shopping in global governance: Understanding states, business and NGOs in multiple arenas. Global Policy, 4(2), 139-149. https://doi.org/10.1111/j.1758-5899.2012.00195.x.

Musah, A. (2013). It is not all about reproductive labour: Excluded traditional ventures and rural livelihoods among women in Northern Ghana. Research on Humanities and Social Sciences, 3(4), 128-136.

Mwanza, D. D. (2003). Water for sustainable development in Africa. Environment, Development and Suatainability, 5(95), 95-115. https://doi.org/10.1023/A:102538201.

Myburgh, G., \& van Niekerk, A. (2014). Impact of training set size on object-based land cover classification. International Journal of Applied Geospatial Research, 5(3), 49-67. https://doi.org/10.4018/ijagr.2014070104.

Naab, F. Z., Dinye, D. R., \& Kasanga, R. K. (2013). Urbanisation and its impact on agricultural lands in growing cities in developing countries: a case study of Tamale, Ghana. Modern Social Science Journal, 2(2), 256-287. Retrieved from http://scik.org.

Naatogmah, A. K. (2015). Urbanet empowers Malshegu women: Cifimonline. Retrieved from http://citifmonline.com/2015/11/16/urbanet-empowers-malshegu-women/.

Nader, L. (1965). The anthropological study of law 1. American Anthropologist, 67(6), 3-32.

Namara, R. E., Horowitz, L., Kolavalli, S., Kranjac-Berisavljevic, G., Dawuni, B. N., Barry, B., \& Giordano, M. (2011). Typology of irrigation systems in Ghana. Colombo, Sri Lanka: International water management institute, working paper 42. Retrieved from http://www.iwmi.cgiar.org/Publications/Working_Papers/working/WOR142.pdf.

Namara, R. E., Horowitz, L., Nyamadi, B., \& Barry, B. (2011). Irrigation development in Ghana: Past experiences, emerging opportunities, and future directions: Ghana strategy support program, working paper No. 0027. Retrieved from http://www.ifpri.org/publication/irrigation-development-ghana.

Naylor, R. (2000). Ghana: An Oxfam country profile. Oxfam publishing. Oxford.

Nchanji, E. B., \& Bellwood-Howard, I. (2016a). Traditional Provisional Responsibilities of Women in Northern Ghana. In V. Demos \& M. Segal (Eds.), Gender and food. From production to consumption and after (pp. 41-64). London: Emerald Group Publ.

Nchanji, E. B., \& Bellwood-Howard, I. (2018a). Governance in urban and peri-urban vegetable farming in Tamale, Northern Ghana. Land Use Policy, 73, 205214. https://doi.org/10.1016/j.landusepol.2018.01.011.

Nchanji, E. B., Bellwood-Howard, I., Schareika, N., \& Chagomoka, T. (2016b). Family Farming in Urban and Peri-urban Farming in Tamale: Poster presentation, Vienna. Tropentag.

Nchanji, E. B., Bellwood-Howard, I., Schareika, N., Chagomoka, T., Schlesinger, J., Axel, D., \& Rüdiger, G. (2017). Assessing the sustainability of vegetable production practices in Northern 
Ghana. International Journal of Agricultural Sustainability, 15(3), 321-337. https://doi.org/10.1080/14735903.2017.1312796.

Nchanji, E. B., Hope, L., \& Nchanji Yvonne Kiki. (2018b) Pest management among smallholder cabbage growers. International Journal of Vegetable Science, 1-16. doi: 10.1080/19315260.2018.1443189.

Ncube, M. (2012). Africa in 50 years: The road towards incusive growth. Journal of African Deveopment, 15(2), 139-154.

Neale, W. C. (1998). Property: Law, cotton-pickin' hands, and implicit cultural imperialism. In R. C. Hunt \& A. Gilman (Eds.), Monographs in economic anthropology: Property in economic context (pp. 47-66). Lanham: University Press of America.

Niangado, O. (2010). Varietal development and seed system in west Africa: Challenges and opportunities: Innovation and partnership to realise Africa's rice potential. In second Africa rice congress, Bamako, Mali. Retrieved from http://kinki-ecotech.jp/download/2011paper/Africa\%20Rice\%20Congress\%202010\%20Proceedings/0P1\%20Niangado\%20fin.pdf.

Nii-K, P. (2007). Underdevelopment in Northern Ghana: natural causes or colonial capitalism? Review of African Political Economy, 6(15-16), 4-14. https://doi.org/10.1080/03056247908703393.

Niñez, V. K. (1984). Household gardens: theoretical considerations on an old survival strategy: Potatoes in food systems research series report nos 1. International Potato Center. Retrieved from https://books.google.de/books?hl=en\&lr=lang_en\&id=JiLX1le-

Moi0C\&oi=fnd\&pg=PA5\&dq=Ninez, $+\mathrm{V}+\mathrm{K}+1984+$ household + gar -

dens\&ots=J4Cs0DAq0m\&sig=RSpTSX_g_W7nJq-C23auiF_mLpc\#v=onepage\&q\&f=false.

Niñez, V. K. (1987). Household gardens: Theoretical and policy considerations. Agricultural Systems, 23, 167-186.

Nkrumah, F., Klutse, Nana Ama Browne, Adukpo, D. C., Owusu, K., Quagraine, K. A., Owusu, A., \& Gutowski, W. (2014). Rainfall variability over Ghana: Model versus rain gauge observation. International Journal of Geosciences, 05(07), 673-683. https://doi.org/10.4236/ijg.2014.57060.

Nkrumah, K. (1973). I speak Freedom: Panaf.

Noble, H., \& Smith, J. (2015). Issues of validity and reliability in qualitative research. Evidence-based nursing, 18(2), 34-35. https://doi.org/10.1136/eb-2015-102054.

North, D. (1981). Structure and change in economic history. New York: W. W. Norton and Co.

Nugent, R. (2000). The impact of urban agriculture on the household and local economies. In Bakker, N., Dubbeling, M., Gundel, S., Sabel-Koschella, U \& H. de Zeeuw (Eds.), Growing cities, growing food: Urban agriculture on the policy agenda (pp.67-97). Feldafing, Germany.

Nuijten, M. (2003). Power, community and the state. The political anthropology of organisation in Mexico. London and Sterling: VA: Pluto Press. 
Obeng-Odoom, F. (2014). Urban land policies in Ghana: A case of the emperor's new clothes? The Review of Black Political Economy, 41(2), 119-143. https://doi.org/10.1007/s12114-0139175-5.

Obusu-Mensah, K. (2002). Changes in official attitudes towards urban agriculture in Accra. African Studies Quarterly, 6(3), 19-32.

Ofori-Boateng, J. (1977). Environmental law: Ghana water laws. Review of Ghana Law, 9(1), 11-37. Olivecrona, K. (1974). Appropriation in the state of nature: Locke on the origin of property. Journal of the History of Ideas, 35(2), 211. https://doi.org/10.2307/2708759.

Olivier de Sardan, J. P. (2015). Practical norms: informal regulations within public bureaucracies (in Africa and beyond). In T. de Herdt \& J.-P. Oliver de Sardan (Eds.), Real governance and practical norms in sub-Saharan Africa. The game of rules (pp. 19-65). London: Taylor and Francis.

Ollennu, N. A. (1971). The changing law and law reform in Ghana. Journal of African Law, 15(02), 132-181. https://doi.org/10.1017/S0021855300006781.

Ollenu, N. A. (1962). Principles of customary land law in Ghana. London: Sweet and Maxwell.

Opuku-Agyemang. (2005). The role of the district assemblies in the management of trans-district water basins in Ghana. International workshop on african water laws: Plural legislative framework for rural water management in Africa, Johannesberg, South Africa.

Orsini, F., Kahane, R., Nono-Womdim, R., \& Gianquinto, G. (2013). Urban agriculture in the developing world: A review. Agronomy for Sustainable Development, 33(4), 695-720. https://doi.org/10.1007/s13593-013-0143-z.

Ostrom, E. (1986). An agenda for the study of institutions. Public Choice, 48(1), 3-25.

Ostrom, E., \& Schlager, E. (1996). The formation of property rights. In S. Hanna, C. Folke, \& K.-G. Mäler (Eds.), Rights to nature: Ecological, economic, cultural and political principles of institutions for the environment (pp. 127-156). Washington, D.C. Island Press.

Ouma, S. (2015). Assembling export markets: The making and unmaking of global food connections in West Africa: John Wiley \& Son.

Owusu Baah. (1995). Technology Adoption by small-scale farmers in Ghana. In M. O. Ogbu, O. Oyelaran-Oyeyinka, \& H. M. Mlawa (Eds.), Technology policy and practice in Africa (pp. 197210). Ottawa: International development research centre.

Owusu, F. (2003). Pragmatism and the gradual shift from dependency to neoliberalism: The world bank, african leaders and development policy in Africa. World Development, 31(10), 16551672.

Owusu-Ansah, D. (2014). Historical dictionary of Ghana. UK and USA: Bowman and Littlefield.

Owusu-Mensah, I. (2014). Politics, chieftaincy and customary law in Ghana's fourth republic. The Journal of Pan African Studies, 6(7). 
Paaga, D.T. (2013). Customary, land tenure and its implications for land disputes in Ghana: Cases from Wa, Wechau and Lambussie. International Journal of Humanities and Social Science, 3(18), 263-270.

Packard, J. (2008). 'I'm gonna show you what it's really like out here': the power and limitation of participatory visual methods. Visual Studies, 23(1), 63-77. https://doi.org/10.1080/14725860801908544.

Parlett, M., \& Hamilton, D. (1976). Evaluation as illumination: A new approach to the study of innovatory programs. In G. Glass (Ed.), Evaluation Studies Review Annual (pp.1-35). Beverly Hills, CA: Sage.

Patton, M. Q. (2002). Qualitative evaluation and research methods. Thousand Oaks, CA: Sage Publications Inc.

Paulson, S., Gezon, L. L., \& Watts, M. (2003). Locating the political in political ecology: An introduction. Human Organization, 62(3), 205-217.

Peet, R., \& Watts, M. (1993). Introduction: Development theory and environment in an age of market triumphalism. Economic Geography, 69(3), 227-253. Retrieved from http://www.jstor.org/stable/143449.

Peluso, N. L. (1996). Fruit trees and family trees in an anthropogenic forest: Ethics of access, property zones, and environmental change in Indonesia. Comparative Studies in Society and History, 38(03), 510. https://doi.org/10.1017/S0010417500020041.

Pillow, W. (2003). Confession, catharsis, or cure? Rethinking the uses of reflexivity as methodological power in qualitative research. Qualitative Studies in Education, 16(2), 175-196. https://doi.org/10.1080/0951839032000060635.

Platteau, J. P. (1996). The evolutionary theory of land rights as applied to sub-Saharan Africa: A critical assessment. Development and Change, 27(1), 29-86.

Prain, G., Lee Smith, D., \& Karanja, N. (2010). African urban harvest; agriculture in the cities of Cameroon, Kenya and Uganda. New York, Ottawa, Lima Peru: Springer.

Pretty, J. (2002). Agriculture, reconnecting people, land and nature. London: Earthscan.

Pretty, J., \& Bharucha, Z. P. (2014). Sustainable intensification in agricultural systems. Annals of Botany, 114(8), 1571-1596. https://doi.org/10.1093/aob/mcu205.

Pul, H. (2003). Exclusion, association and violence: Trends and triggers in Northern Ghana's Konkomba-Dagomba wars. The African Anthropologist, 10(1), 39-82.

Puplampu, K. (2003). State-NGO relations and agricultural sector development. In W. Tettey, K. Puplampu, \& B. Bermen (Eds.), Critical perspectives in politics and socio-economic development in Ghana. Leiden, Netherlands: Brill Academic.

Quan, J., Ubink, J., \& Antwi, A. (2008). Risks and opportunities of state intervention in customary land management: Emergent findings from the land administration project Ghana. In J. M. Ubink \& 
K. Amanor (Eds.), Contesting land and custom in Ghana. State, chief and the citizen (pp. 183208). [Leiden]: Leiden University Press.

Quarcoopome, S. S. (1992). Urbanisation, land alienation and politics in Accra. Research Review, $8(1$ and 2$), 40-54$.

Quartey, P. (2003). Accountability within the house of chiefs and traditional councils: A review of the auditor-general's reports. Institute of Economic Affairs (Ghana)-Legislative Alerts, 2(3), 1-8.

Radetzki, M., \& Lipton, M. (1978). Why poor people stay poor: Urban bias in world development. The Scandinavian Journal of Economics, 80(3), 337. https://doi.org/10.2307/3439587.

Rathbone, R. (2000a). Native courts, local courts, chieftaincy and the CPP in Ghana in the 1950s. Journal of African Cultural Studies, 13(1), 125-139. https://doi.org/10.1080/713674304.

Rathbone, R. (2000b). Nkrumah \& the chiefs: The politics of chieftaincy in Ghana, 1951-1960. Oxford, Athens, Ohio, Accra: James Currey; Ohio University Press; F. Reimmer.

Rattray, R. S. (1932). The tribes of the Ashanti hinterland: Clarendon Press.

Raustiala, K., \& Victor, D. G. (2004). The regime complex for plant genetic resources. International Organization, 58(02). https://doi.org/10.1017/S0020818304582036.

Ribot, J. C. (1998). Theorizing access: Forest profits along Senegal's charcoal commodity chain. Development and Change, 29(2), 307-341.

Ribot, J. C., \& Peluso, N. L. (2003). A theory of access. Rural Sociology, 68(2), 153-181.

Robbins, P. (2012). Political ecology: A critical introduction (2nd ed). Chichester, U.K., Malden, Mass: J. Wiley \& Sons.

Robinson, L. W., Ericksen, P. J., Chesterman, S., \& Worden, J. S. (2015). Sustainable intensification in drylands: What resilience and vulnerability can tell us. Agricultural Systems, 135, 133-140. https://doi.org/10.1016/j.agsy.2015.01.005.

Rocheleau, D., \& Ross, L. (1995). Trees as tools, trees as text: Struggle over resources in ZambranaChacuey, Dominican Republic. Antipode, 27(4), 407-428. https://doi.org/10.1111/j.14678330.1995.tb00287.x.

Rose, M. C. (1994). Property and persuasion: Essays on the history, theory, and rhetoric of ownership: Boulder: Westview Press.

Rose, N. (1987). Beyond the public/private division: Law, power and the family. Journal of Law and Society, 14(1), 61. https://doi.org/10.2307/1410297.

Rose, N. (1996). Governing "advanced" liberal democracies. In A. Barry, T. Osborne, \& N. Rose (Eds.), In foucault and political reason: Liberalism, neo-liberalism and rationalities of government (pp. 37-64). Chicago: University of Chicago Press.

Rose, N. S. (1999). Powers of freedom: Reframing political thought. Cambridge, United Kingdom, New York: Cambridge University Press. 
Rose, N., \& Miller, P. (2010). Political power beyond the state: problematics of government. The British journal of sociology, 61 Suppl 1, 271-303. https://doi.org/10.1111/j.14684446.2009.01247.x.

Rose, N., \& Novas, C. (2007). Biological citizenship. In A. Ong \& S. J. Collier (Eds.), Global assemblages: Technology, politics, and ethics as anthropological problems (pp. 439-463). Oxford, UK: Blackwell Publishing Ltd.

Rose, N., O'Malley, P., \& Valverde, M. (2006). Governmentality. Annual review of law and social science, 2, 83-104.

Rossman, G., \& Rallis, S. F. (2012). Learning in the field: An introduction to qualitative research. Thousand Oaks, CA: Sage.

Rowe, W. C. (2009). "Kitchen gardens" in Tajikistan: The economic and cultural importance of smallscale private property in a post-soviet society. Human Ecology, 37(6), 691-703. https://doi.org/10.1007/s10745-009-9278-6.

Saavedra, Y., Dijkxhoorn, Y., Elings, A., Glover-Tay, J., Koomen, I., Edwin van der Maden,. . Obeng, P. (2014). Vegetables business opportunities in Ghana: 2014. GhanaVeg Sector Report, 145. Retrieved from https://www.rvo.nl/sites/default/files/2015/04/Vegetables\%20Business\%20Opportunities\%20in\%20Ghana\%202014.pdf.

Sakyi, K. E. (2003). Gone but not forgotten': Chieftaincy, accountability and state audit in Ghana, 1993-99. African Sociological Review, 7(1), 131-145.

Sarbah, J. M. (1968). Fanti customary laws. London: Frank Cass and Co.

Sarpong, G. (2004). "Going down the drain? Customary water law and legislative onslaught in Ghana." FAO.

Sarpong, G. A. (2005). Customary water law and practices: Ghana. Food and agriculture organization of the united nations.

Sarpong, G. A. (2006). Improving tenure security for the rural poor: Ghana country sase study. LEP Working Paper nos 2.

Schlager, E., \& Ostrom, E. (1992). Property-rights regimes and natural resources: A conceptual analysis. Land Economics, 68(3), 249. https://doi.org/10.2307/3146375.

Schutt, R. K. (2012). Investigating the social world: The process and practice of research. Thousand Oaks, Calif.: Sage Publications.

Schutz, A. (1954). Concept and theory formation in the social sciences. The Journal of Philosophy, 51(9), 257. https://doi.org/10.2307/2021812.

Scoones, I., \& Thompson, J. (2011). The politics of seed in Africa's green revolution: Alternative narratives and competing pathways. IDS Bulletin, 42(4), 1-23. https://doi.org/10.1111/j.17595436.2011.00232.x.

Scott, J. C. (1998). Seeing like a state: How certain schemes to improve the human condition have failed. Yale University Press. 
Scott, J. C. (2009). The art of not being governed: An anarchist history of upland Southeast Asia. Yale agrarian studies series. New Haven: Yale University Press.

Seidman, I. (2006). Interviewing as qualitative research: A guide for researchers in education and the social sciences. New York: Teachers College Press.

Seidu, A.-h. (2009). Non-traditional vegetable production in the northern region of Ghana: A profit function analysis. Ghana Journal of Development Studies, 6(1), 93-108.

Sending, Ole Jacob, \& Neumann, I. B. (2006). Governance to governmentality: Analyzing NGOs, states, and power. International Studies Quarterly, 50(3), 651-672. https://doi.org/10.1111/j.1468-2478.2006.00418.x.

Shaffer, P. (2015). Colonialism and seasonal poverty in the northern territories of the Gold Coast, circa 1900-1940. Q- Squared working paper. (65), 1-18.

Sikor, T., \& Lund, C. (2009). Access and property: A question of power and authority. Development and Change, 40(1), 1-22.

Simon, D., McGregor, D., \& Thompson, D. (2006). Contemporary perspectives on the peri-urban zones of cities in developing countries. In D. McGregor, D. Simon, \& D. Thompson (Eds.), The peri-urban Interface: Approaches to sustainable natural and human resource use (pp. 3-17). London: Earthscan.

Sinkovics, R. R., \& Alfoldi, E. A. (2012). Progressive focusing and trustworthiness in qualitative research. Management International Review, 52(6), 817-845. https://doi.org/10.1007/s11575012-0140-5.

Sittie, R. (2006). Land title registration: The Ghanaian experience.: Paper presented at the XXIII FIG congress, Munich, Germany, 1-11.

Sjoberg, G., \& Nett, R. (1968). A methodology for social research. New york: Harper and Row.

Smith, J., Ratta, A., \& Nasr, J. (2001). Urban agriculture - food, jobs and sustainable cities. The urban agriculture network.

Smithson, J. (2000). Using and analysing focus groups: limitations and possibilities. International Journal of Social Research Methodology, 3(2), 103-119.

Soto, H. d. (2001). The mystery of capital: Why capitalism triumphs in the West and fails everywhere else. London: Black Swan.

Srivastava, J. (1990). World bank lending for seed industry development: Past experience and future needs. Mimeo. Washington, D. C.: The World Bank.

Staniland, M. (1975). The lions of Dagbon: Political change in Northern Ghana. African studies series: Vol. 16. Cambridge [England], New York: Cambridge University Press.

Stein, H. (1994). Theories of institutions and economic reform in Africa. World Development, 22(12), 1833-1849.

Stenbacka, C. (2001). Qualitative research requires quality concepts of its own. Management Decision, 39(7), 551-555. 
Strathern, M. (2000). The Tyranny of transparency. British Educational Research Journal, 26(3), 309321. Retrieved from http://www.jstor.org/stable/1501878.

Stren, R. E. (1992). An urban problematique: The challenge of urbanization for development assistance. Toronto: Centre for urban and community studies, University of Toronto.

Sugri, I., Abdulai, M. S., Larbi, A., Hoeschle Zeledon, I., Kusi, F., \& Agyare, R. Y. (2015). Participatory variety selection of okra (Abelmoschus esculentus L.) genotypes for adaptation to the semiarid agro-ecology of Northern Ghana. African Journal of Plant Science, 9(12), 466-475. https://doi.org/10.5897/AJPS2015.1340.

Sutton, I. (1989). Colonial agricultural policy: The non-development of the northern territories of the Gold Coast. The International Journal of African Historical Studies, 22(4), 637. https://doi.org/10.2307/219058.

Sutton, I. B. (1981). The volta river salt trade: The survival of an indigenous industry. Journal of African History. (22), 43-61.

Tabor, G., \& Yesuf, M. (2012). Mapping the current knowledge of carrot cultivation in Ethiopia. Technical report submitted to carrot aid. Charlottenlund, Denmark.

Tait, D. (1955). History and social organisation. Transactions of the Gold Coast \& Togoland historical society. Historical Society of Ghana, 1(5), 193-210. Retrieved from http://www.jstor.org/stable/41406592.

Tait, D. (1963). A sorcery hunt in Dagomba. Africa, 33(2).

Talton, B. (2010). Politics of social change in Ghana: The Konkomba struggle for political equality. New York: Palgrave MacMillan.

Tamakloe, E. F. (1931). A brief history of the Dagomba people. Accra: Government Printer.

Tansey, G. (2011). Whose power to control? Some reflections on seed systems and food security in a changing world. IDS Bulletin, 42(4), 111-120. https://doi.org/10.1111/j.17595436.2011.00241.x.

Tauxier, L. (1912). La noir du Soudan. Paris.

Taylor, S. J., Bogdan, R., \& DeVault, M. L. (2015). Introduction to qualitative research methods: A guidebook and resource. Hoboken, New Jersey: John Wiley and Sons, Inc.

Tengan, A. B. (2000). Hoe-farming and social relations among the Dagara of northwestern Ghana and southwestern Burkina Faso (Bd. 54). Frankfurt am Main, New York: Peter Lang.

Tenkorang, S. (1973). John Mensah Sarbah, 1864-1910. Transactions of the Historical Society of Ghana, 14(1). Retrieved from http://www.jstor.org/stable/41405839.

Tenkouano, A. (2012). Vegetables and associated best management practices in cereal-based crop production systems to improve income and diets of rural and urban households in northern Ghana and southern Mali. Retrieved from https://africa-rising.wikispaces.com/west_africa.

The Republic of Ghana. (1992). The 1992 constitution. 
Thuo, A.D.M. (2013). Place of positionality values ethics and reflexivity in qualitative urban field work research. Journal of Human and Social Science Research, 1(1), 19-29.

Tonah, S. (2012). The politicisation of a chieftaincy conflict: The case of Dagbon, Northern Ghana. Nordic Journal of African Studies, 21(1), 1-20.

Tordoff, W. (1965). Ashanti under the prempehs: 1888-1935. London: Oxford University Press.

Tranakides, G. (1953). Observations on the history of some Gold Coast peoples. Transactions of the

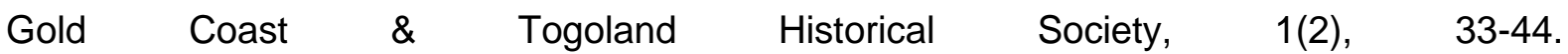
. Historical Society of Ghana, 1(2), 33-44. Retrieved from http://www.jstor.org/stable/41406428.

Trioullot, M. R. (2001). The anthropology of the state in the age of globalization: Close encounters of the deceptive kind. Current Anthropology, 42(1), 125-138.

Tsikata, D., \& Seini, W. (2004). Identities, Inequalities and conflicts in Ghana: Crise working paper No. 30. Department of international development, University of Oxford.

Turner, D. W., III. (2010). Qualitative interview design: A practical guide for novice investigators. The Qualitative Report, 15(3), 754-760. Retrieved from http://www.nova.edu/ssss/QR/QR153/qid.pdf.

Ubink, J. (2007). Traditional authority revisited: popular perceptions of chiefs and chieftaincy in periurban Kumasi, Ghana. The Journal of Legal Pluralism and Unofficial Law, 39(55), 123-161.

Ubink, J. M. (2008). In the land of the chiefs: Customary law, land conflicts, and the role of the state in peri-urban Ghana. Leiden: Leiden University Press.

Ubink, J. M., \& Quan, J. F. (2008). How to combine tradition and modernity? Regulating customary land management in Ghana. Land Use Policy, 25, 198-213.

Unesco World Water Assessment Programme. (2012). Facing the challenges. United Nations world water development report: Vol. 4. Paris: UNESCO [u.a.]. Retrieved from http\%3A/www.worldcat.org/oclc/839698523.

United Nations Habitat. (2008). State of the african cities report 2008: A framework for addressing urban challenges in Africa, UN-Habitat, Nairobi. In: Swilling, M. (2010). "Africa 2050: Growth, resource productivity and decoupling", Policy Brief for the 7th meeting of the international panel for sustainable resource management of the united nations environment programme.

United Nations Habitat. (2015). The state of african cities, 2014: Re-imagining sustainable urban transitions. [S.I.]: United Nations Pubns.

United Nations. (1973). Ground water in Africa. Department of economic and social Affairs, New York, United Nations. ST/ECA/147.

United States Agency for International Development. (2011). Ghana partnership for growth land tenure investigation for constraints analysis. Retrieved from http://usaidlandtenure.net/library/country-level-reports. 
van Dijk, H. (1996). Land tenure, territoriality, and ecological instability: A Sahelian case study. In J. Spiertz \& M. J. Wiber (Eds.), The Role of Law in Natural Resource Management, (17-45.). The Hague: Vuga.

van Koppen, B. (2003). Water reform in sub-Saharan Africa: what is the difference? Physics and chemistry of the earth, Parts A/B/C, 28(20-27), 1047-1053. https://doi.org/10.1016/j.pce.2003.08.022.

van Veenhuizen, R. (2006). Cities farming for the future. In R. van Veenhuizen (Ed.), Cities farming for the future. Urban agriculture for green and productive cities (pp. 1-17). Silang, Philippines, Ottawa: RUAF Foundation; International institute of rural reconstruction; International development research centre.

Venot, J.P. and Cecchi, P. (2011). Valeur ou performances ? Pour un nouveau cadre analytique d'étude des petits barrages d'Afrique sub-saharienne. Les Cahiers de l'Agriculture, 20(1-2), $1-6$.

Visser, G. (2003). Researcher positionality and political-temporal contingency in a post apartheid research environment. Research Papers in Environmental and Spatial Analysis, 1-24.

Ward, W. (1958). A history of Ghana. London: George Allen and Unwin.

Wardell, A., \& Fold, N. (2013). Globalisations in a nutshell: Historical perspectives on the changing governance of the shea commodity chain in northern Ghana. International Journal of the Commons, 7(2), 367-405.

Water Resources Commission. (2001). Water use regulations, 2001. Arrangements for regulations. Accra.

Watson, V. (2009). "The planned city sweeps the poor away...": Urban planning and 21st century urbanisation. Progress in Planning, 72(3), 151-193. https://doi.org/10.1016/j.progress.2009.06.002.

Watts, M. (2003). Political ecology. In E. S. Sheppard \& T. J. Barnes (Eds.), A companion to economic geography (pp. 257-274). Oxford, Malden, Mass.: Blackwell.

Weiss, H. (2004). Locust invasions in colonial Northern Ghana. Working paper on Ghana: Historical and Contemporary Studies 3.

White, B., Borras Jr., Saturnino M., Hall, R., Scoones, I., \& Wolford, W. (2012). The new enclosures: critical perspectives on corporate land deals. Journal of Peasant Studies, 39(3-4), 619-647. https://doi.org/10.1080/03066150.2012.691879.

Whitehead, T. L. (2005). Basic classical ethnographic research methods secondary data analysis, fieldwork, observation/participant observation, and informal and semi-structured interviewing: ethnographically informed community and cultural assessment research systems (EICCARS) Working paper series. Cultural Ecology of Health and Change, 1-28.

Wiber, M. G. (1993). Politics, property and law in the Philippine uplands: Wilfrid Laurier University Press. 
Wilks, I. (1975). Ashante in the nineteenth century. Cambridge: Cambridge University Press.

Winter, G. (2000). A comparative discussion of the notion of validity in qualitative and quantitative research [58 paragraphs]. The Qualitative Report, 4(3\&4). Retrieved from http://www.nova.edu/ssss/QR/QR4-3/winter.html.

Wolf, E. (1972). Ownership and political ecology. Anthropological Quarterly, 45, 201-205. https://doi.org/10.2307/3316532.

Worboys, M. (1988). The discovery of colonial malnutrition between the wars. In D. Arnold (Ed.), Imperial Medicine and Indigenous Societies (pp. 208-255). Manchester: Manchester University Press.

World Bank. (1981). Accelerated development in sub-Saharan Africa: An agenda for action. World Bank, Washington, DC.

World Bank. (2011). Project appraisal document on a proposed credit in the amount of SDR 15.1 million (US dollars 20.5 million equivelent) to the republic of Ghana for a land administartion project. Report no: 58334-GH. Retrieved from http://www.ghanalap.gov.gh/files/PAD.pdf.

World Bank. (2013). Fact sheet: The world bank and agriculture in Africa: Accessed on the 11th of August 2016. Retrieved from http://web.worldbank.org/WBSITE/EXTERNAL/COUNTRIES/AFRICAEXT/0,,content-

MDK:21935583 pagePK:146736 piPK:146830 theSitePK:258644,00.html.

World Bank. (2014). 3.12 world bank indicators: Urbanization. Retrieved from http://wdi.worldbank.org/table/3.12.

World Bank. 2004. Bridging the north south divide in Ghana. Washington, DC: World Bank. https://openknowledge.worldbank.org/handle/10986/9053.

Yaro, J. A. (2010). Customary tenure systems under siege: contemporary access to land in Northern Ghana. GeoJournal, 75(2), 199-214. https://doi.org/10.1007/s10708-009-9301-x.

Yaro, J. A. (2012). Re-inventing traditional land tenure in the era of land commoditization: some consequences in periurban Northern Ghana. Geografiska Annaler: Series B, Human Geography, 94(4), 351-368. https://doi.org/10.1111/geob.12003.

Yates, L. (2010). The story they want to tell, and the visual story as evidence: young people, research authority and research purposes in the education and health domains. Visual Studies, 25(3), 280-291. https://doi.org/10.1080/1472586X.2010.523281.

Zezza, A., \& Tasciotti, L. (2010). Urban agriculture, poverty, and food security: Empirical evidence from a sample of developing countries. Food Policy, 35(4), 265-273. https://doi.org/10.1016/j.foodpol.2010.04.007.

Ziem, J., \& Gyebi, E. (2011). Tamale - West Afica's fastest growing city. Tamale, Northern Ghana: Savannah news. Retrieved from http://savannahnewsblogspotcom.blogspot.de/2011/11/tamale-west-africas-fastest-growing.html. 
Žikić, B. (2007). Qualitative field research in anthropology: An overview of basic research methodology. The Journal Issues in Ethnology and Anthropology, 2(2), 123-137.

Zohary, D., Hopf, M., \& Weiss, E. (2012). Domestication of plants in the old world: The origin and spread of domesticated plants in Southwest Asia, Europe, and the Mediterranean Basin. Oxford: Oxford University Press. 